UNIVERSIDADE DE SÃO PAULO

FACULDADE DE ECONOMIA, ADMINISTRAÇÃO E CONTABILIDADE DEPARTAMENTO DE ADMINISTRAÇÃO PROGRAMA DE PÓS-GRADUAÇÃO EM ADMINISTRAÇÃo

ALMEJANDO O MUNDO DO FUTURO: A PROPOSIÇÃO DE UM MODELO PROSPECTIVO GLOBAL PARA PRODUÇÃO E CONSUMO SUSTENTÁVEL DE CARNE BOVINA

Regina da Silva Ornellas

Orientador: Prof. Dr. James T. C. Wright

SÃO PAULO 
Prof. Dr. Marco Antonio Zago

Reitor da Universidade de São Paulo

Prof. Dr. Adalberto Américo Fischmann

Diretor da Faculdade de Economia, Administração e Contabilidade

Prof. Dr. Roberto Sbragia

Chefe do Departamento de Administração

Prof. Dr. Moacir de Miranda Oliveira Júnior

Coordenador do Programa de Pós-Graduação em Administração 


\title{
ALMEJANDO O MUNDO DO FUTURO: A PROPOSIÇÃO DE UM MODELO PROSPECTIVO GLOBAL PARA PRODUÇÃO E CONSUMO SUSTENTÁVEL DE CARNE BOVINA
}

\author{
Tese apresentada ao Departamento de Administração da \\ Faculdade de Economia, Administração e Contabilidade \\ da Universidade de São Paulo como requisito parcial \\ para a obtenção do título de Doutor em Ciências.
}

Orientador: Prof. Dr. James T. C. Wright

\section{Versão Corrigida \\ (versão original disponível na Biblioteca da Faculdade de Economia, Administração e Contabilidade)}

\section{SÃO PAULO}




\section{FICHA CATALOGRÁFICA}

Elaborada pela Seção de Processamento Técnico do SBD/FEA/USP

Ornellas, Regina da Silva

Almejando o mundo do futuro: a proposição de um modelo prospectivo global para produção e consumo sustentável de carne bovina / Regina da Silva Ornellas. - São Paulo, 2017.

$209 \mathrm{p}$.

Tese(Doutorado) - Universidade de São Paulo, 2017

Orientador: James Terence Coulter Wright.

1. Indicadores científicos - Aspectos ambientais 2. Economia - Crescimento e desenvolvimento 3. Pecuária - Aspectos ambientais 4. Prospectiva I. Universidade de São Paulo. Faculdade de Economia, Administração e Contabilidade. II. Título.

CDD -501 
Dedico esse trabalho primeiramente a Jeová Deus, pela saúde, fé e perseverança que me tem dado e a meus amigos e familiares pelo incentivo à busca de novos conhecimentos. 


\section{AGRADECIMENTOS}

Os anos de pesquisa em que desenvolvi esta tese foram uma árdua jornada de desafio, construção e amadurecimento. Nenhum empreendimento é realizado de forma fácil e sem esforço. Tampouco é realizado sem a colaboração, estímulo e empenho de diversas pessoas. Por isso, eu gostaria de expressar toda a minha gratidão a todos aqueles que, direta ou indiretamente, contribuíram para que essa tarefa se tornasse uma realidade.

Agradeço a Jeová Deus, pela vida, saúde, sabedoria e a quem devo tudo que sou.

Ao meu orientador Prof. Dr. James Wright sou grata pelos conselhos, paciência, confiança e suporte em todas as etapas envolvidas na conquista deste doutorado.

Aos professores da FEA USP, em especial aos pertencentes ao departamento de Administração pela capacidade de nos motivar a pesquisa acadêmica.

Meus respeitosos agradecimentos pela valiosa contribuição dos membros da banca do exame de qualificação: Prof. Dr. Isak Kruglianskas e Profa. Dra. Renata Giovinazzo Spers.

Agradeço a equipe PROFUTURO (Cristiane Alves e Elaine Lima) pela amizade, incentivo e cooperação nessa fase desafiadora.

Meus agradecimentos especiais ao amigo Prof. Dr. Durval Lucas Jr., pelos momentos de amizade, incentivo e reflexões críticas. Ao amigo Prof. Antonio Carlos Berardi Jr., agradeço a sua disponibilidade irrestrita, apoio, bom humor e reflexões, que amenizaram momentos difíceis, divertiram momentos leves e contribuíram para o desenvolvimento dessa tese.

E por fim, agradeço em especial àqueles que sempre me apoiaram incondicionalmente, que apostaram em mim mais do que ninguém, que compreenderam todos os meus momentos de ausência e que seguramente são os que mais compartilham da minha alegria: minha família minha mãe Quitéria, meu marido Reginaldo e meu irmão Roberto. 
"Os que se encantam com a prática sem a ciência são como os timoneiros que entram no navio sem timão nem bússola, nunca tendo certeza do seu destino".

(Leonardo da Vinci) 



\section{RESUMO}

ORNELlAS, Regina da Silva Almejando o Mundo do Futuro: A proposição de um Modelo Prospectivo Global para Produção e Consumo Sustentável de Carne Bovina. 2017. 207 p. Tese (Doutorado em Administração) - Faculdade de Economia, Administração e Contabilidade, Universidade de São Paulo, São Paulo, 2017.

Com a população mundial prevista para chegar a 9 bilhões de pessoas durante o século 21 , ocorre também o aumento na demanda de carne bovina, que segue acompanhado de aumento no consumo de recursos naturais do planeta. Entre os impactos causados pelo aumento da demanda está uma atmosfera que se aquece pelas emissões de gases do efeito estufa. Em vista disso, a busca de eficiência tecnológica no uso de recursos torna-se um alvo, porém tratado de forma secundária pelo segmento. Considerando as possibilidades atuais e futuras da produção e consumo global de carne bovina, quatro cenários prospectivos podem surgir para 2040, os quais envolvem a tecnologia de diferentes formas. Logo, essa pesquisa respondeu a pergunta: Quais cenários plausíveis de produção e consumo global sustentável de carne bovina podem ser projetados para 2040? Para responder a essa pergunta e atingir os objetivos de pesquisa, foi desenvolvida uma inédita metodologia, composta por quatro distintas fases. Como fator preponderante para a resposta de pesquisa, foi desenvolvido um modelo prospectivo, o qual identifica um padrão global sustentável de produção e consumo de carne bovina para 2040. Através do modelo, foram desenvolvidos quatro cenários prospectivos para a produção e consumo global da pecuária bovina de corte: um cenário que contempla a atual produção, consumo e tecnologia; três cenários que incluem avanços tecnológicos, projeção de demanda, população e Pib per capita. Através do modelo e de seus respectivos cenários, foi possível analisar que há embora hajam diferentes níveis de produção e consumo global, é possível buscar de forma efetiva a sustentabilidade global mediante a mudança de eficiência no uso de recursos naturais, avanços tecnológicos e a implementação de políticas públicas de produção. Através da pesquisa também foi possível perceber que a aplicação de técnicas de cenários prospectivos são de suma importância para avanços acadêmicos e a tomada de decisão de gestores.

Palavras-chave: Indicadores Científicos (Aspectos Ambientais); Economia (Crescimento e Desenvolvimento); Pecuária (Aspectos Ambientais); Prospectiva. 



\begin{abstract}
ORNELLAS, Regina da Silva Aiming at the Future: Proposing a Global Prospective Model for the Sustainable Production and Consumption of Bovine Meat. 2017. 207 p. Tese (Doutorado em Administração) - Faculdade de Economia, Administração e Contabilidade, Universidade de São Paulo, São Paulo, 2017.
\end{abstract}

The world population is expected to reach 9 billion people during the 21st century; therefore, there is an increase in the demand for bovine meat, which is accompanied by an increase in the consumption of natural resources of the planet. Among the impacts caused by this rising demand is an atmosphere that is heating up by greenhouse gas emissions. In view of this, the search for technological efficiency in the use of resources becomes a target, but it is treated in a secondary way by the segment. Therefore, this research answered the question: What plausible scenarios of sustainable global bovine meat production and consumption can be projected for 2040? To answer this question and achieve the research objectives, an unprecedented methodology was developed, composed of four distinct phases. As a preponderant factor for the research response, a prospective model was developed, which identifies a sustainable global pattern of beef production and consumption by 2040. Through the model, four prospective scenarios were developed for the global production and consumption of bovine livestock Of cut: a scenario that contemplates the current production, consumption and technology; Three scenarios that include technological advances, projection of demand, population and GDP per capita. Through the model and their respective scenarios, it was possible to analyze that although there are different levels of global production and consumption, it is possible to effectively seek global sustainability through a change in efficiency in the use of natural resources, technological advances and the implementation of Public production policies. The research also made possible to notice that the application of techniques of prospective scenarios are of paramount importance for academic advances and the decision making of managers.

Keywords: Scientific Indicators (Environmental Aspects); Economy (Growth and Development); Livestock (Environmental Aspects); Prospective. 



\section{SUMÁRIO}

1 INTRODUÇÃO

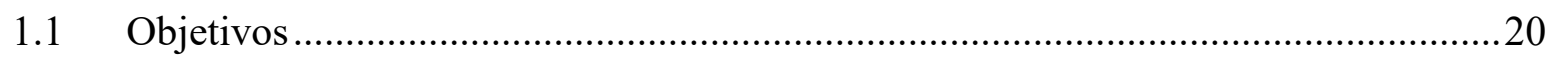

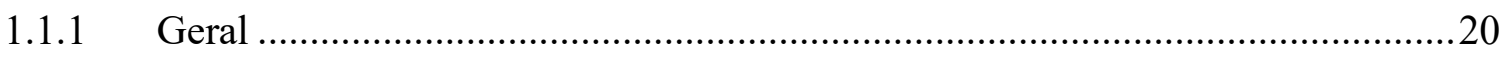

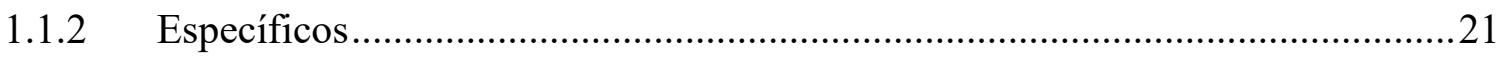

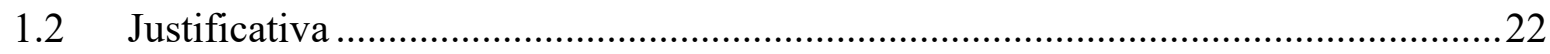

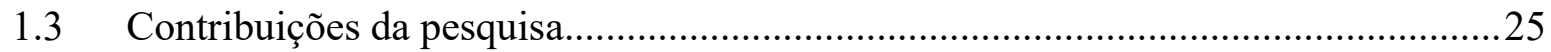

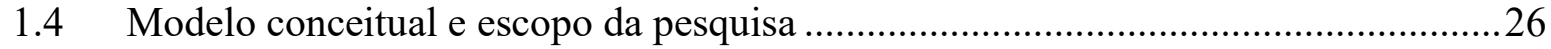

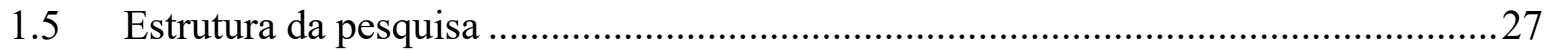

2 MODELOS E PROCEDIMENTOS METODOLÓGICOS …........................................29

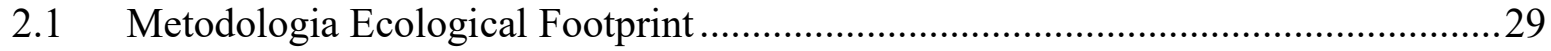

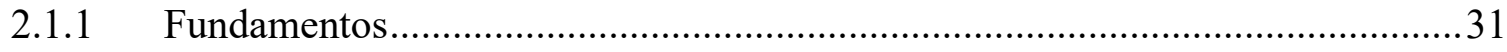

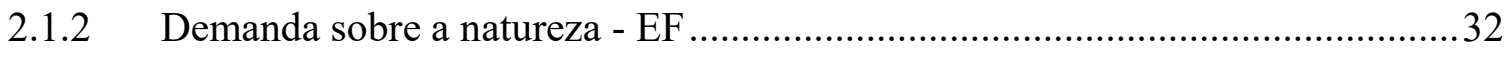

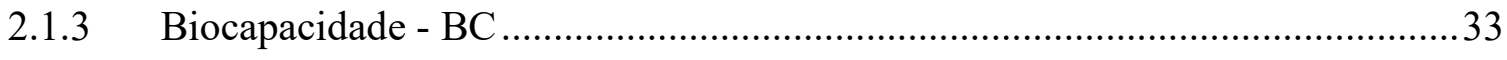

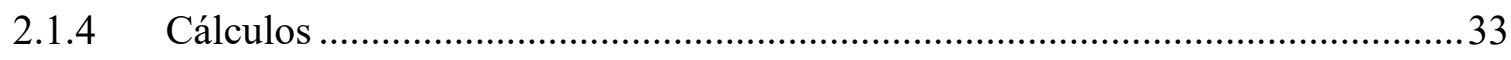

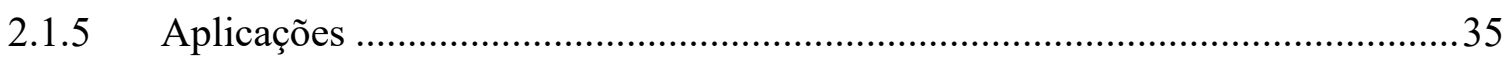

2.1.6 Limitações da EF e Planos de Ação na Pesquisa ...............................................36

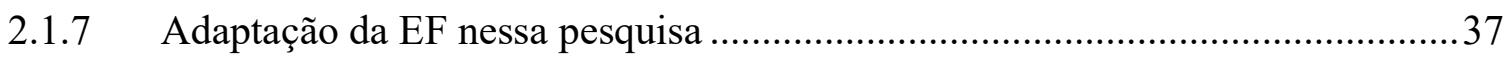

2.2 Metodologia de Cenários Prospectivos............................................................ 40

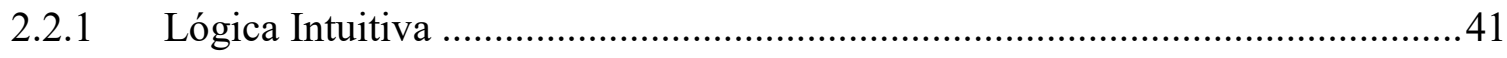

2.2.2 Análise do Impacto de Tendências ....................................................................42

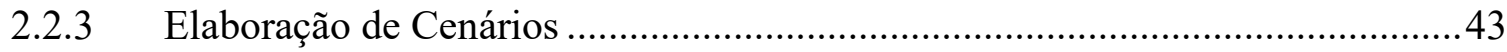

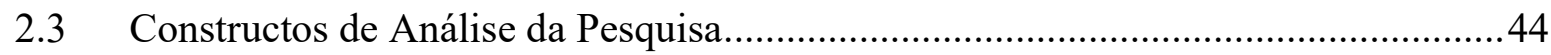

2.4 Escopo e Procedimentos Metodológicos ...............................................................46

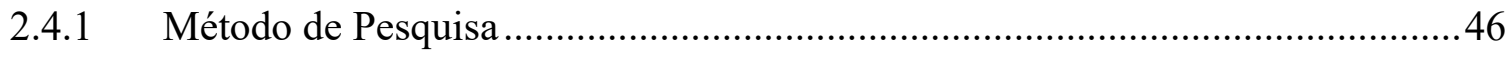

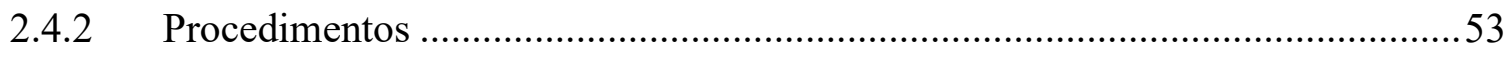

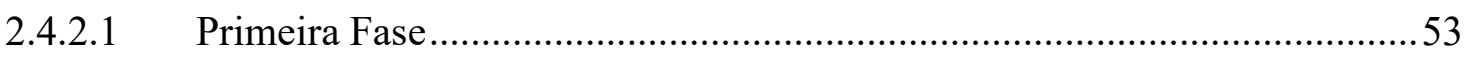




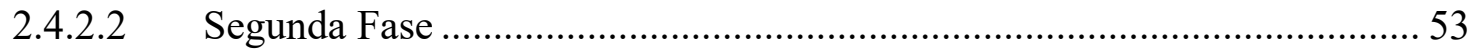

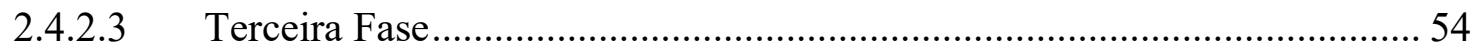

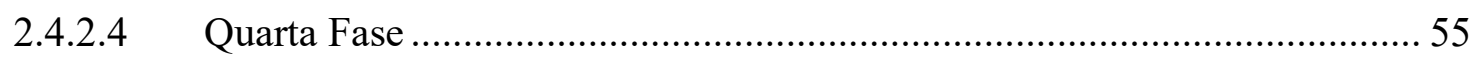

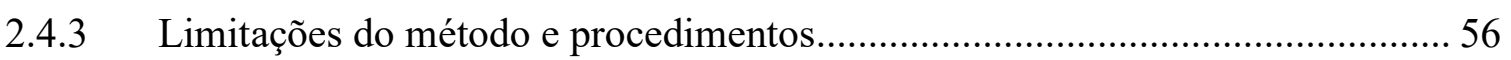

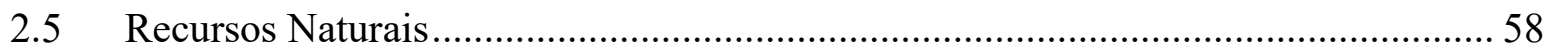

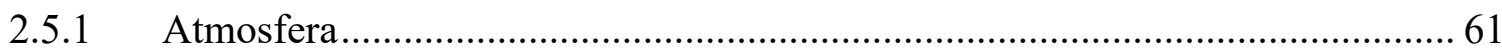

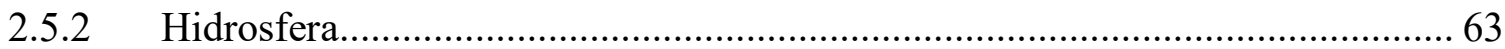

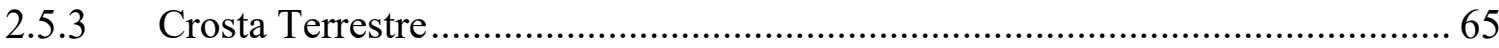

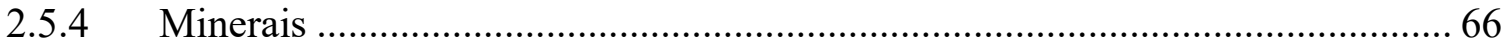

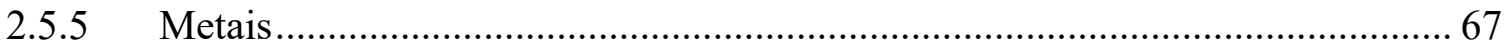

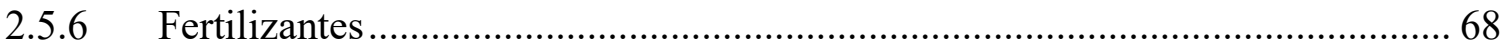

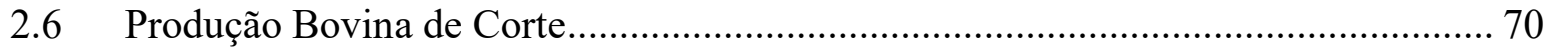

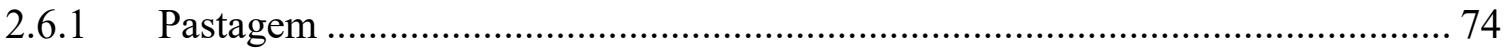

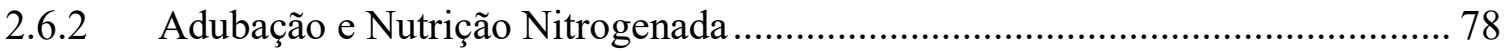

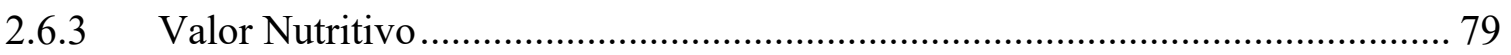

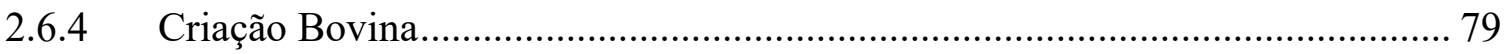

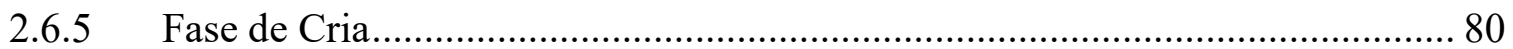

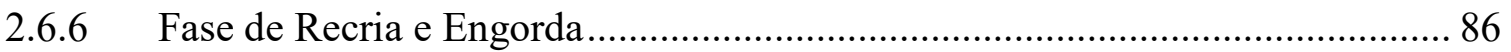

2.6.7 Insumos para produção de alimentos pecuaristas …........................................ 88

2.6.8 Perdas e Desperdício na Agropecuária .......................................................... 103

2.6.9 Consequências do uso de recursos naturais na Agropecuária........................... 105

2.6.10 Variáveis influenciadoras na produção de alimentos pecuaristas .................... 110

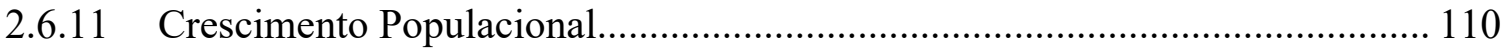

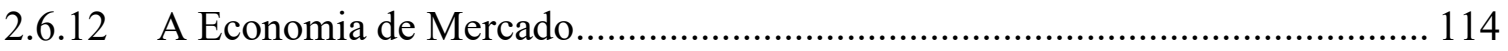

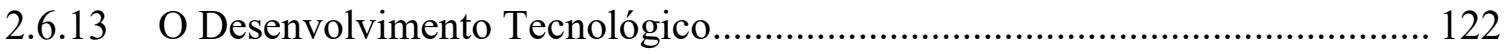

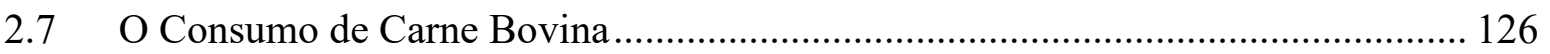

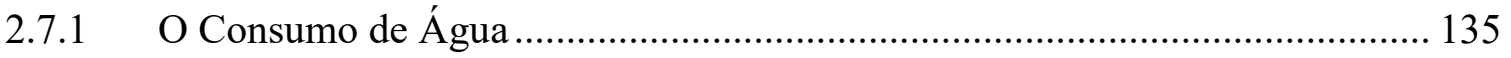

2.7.2 Variáveis influenciadoras no consumo de alimento ...................................... 137 


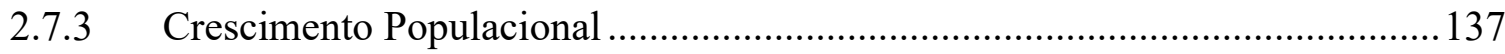

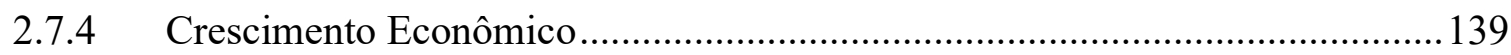

2.7.5 Instituições Político-Econômicas e o Marketing ................................................ 140

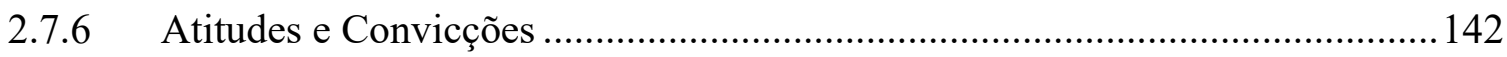

2.8 Sustentabilidade na Produção e Consumo Bovino de Corte....................................... 144

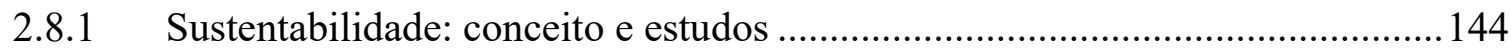

2.8.2 Sustentabilidade e a produção de carne bovina .............................................. 145

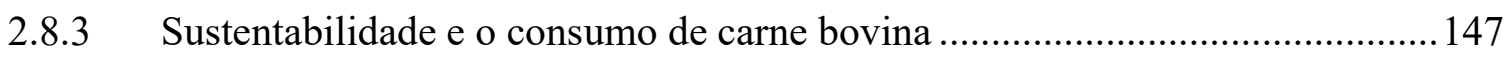

3 ANÁLISE E DISCUSSÃO DE RESULTADOS ...................................................... 151

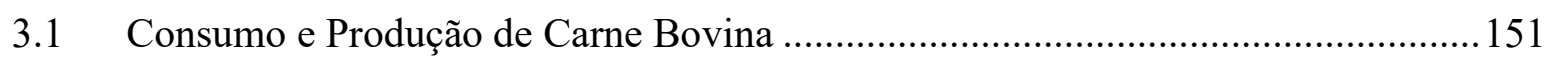

3.2 Consumo de Carne Bovina: relação com a população e Pib per capita ................... 155

3.3 Tendência de Consumo Global de Carne Bovina .................................................. 157

3.4 Modelo de Produção e Consumo Sustentável de Carne Bovina................................ 158

3.5 Simulações do Modelo Sustentável de Carne Bovina para 2040 ............................ 159

3.6 Cenários de Produção e Consumo Sustentável de Carne Bovina .............................159

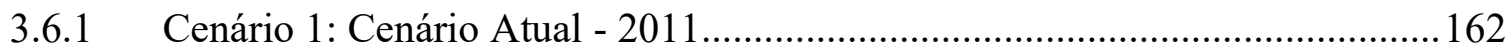

3.6.2 Cenário 2: Cenário 2040 com Tecnologia Atual........................................... 163

3.6.3 Cenário 3: Cenário 2040 com Avanço Tecnológico Moderado ......................... 164

3.6.4 Cenário 4: Cenário 2040 com tecnologia em busca da sustentabilidade........... 165

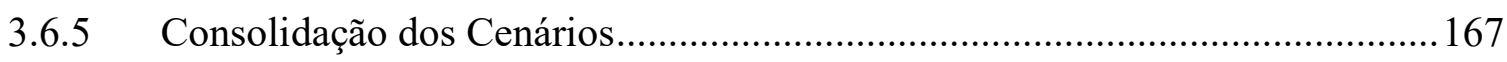

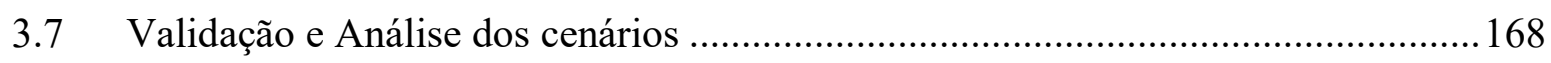

3.7.1 Conexão da validação dos cenários com o modelo da pesquisa........................ 173

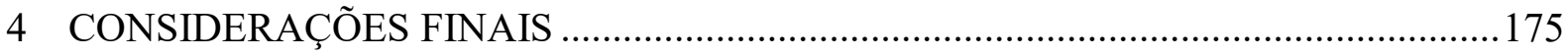

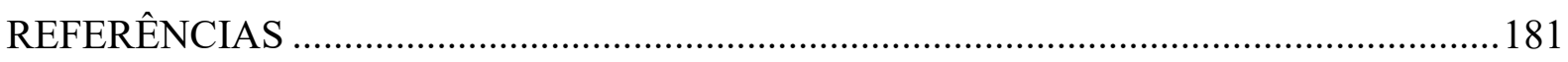

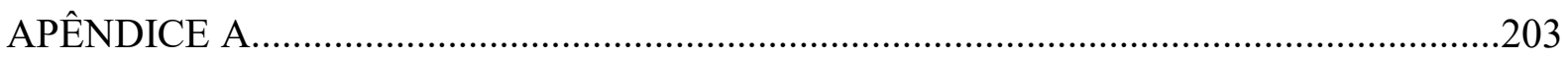

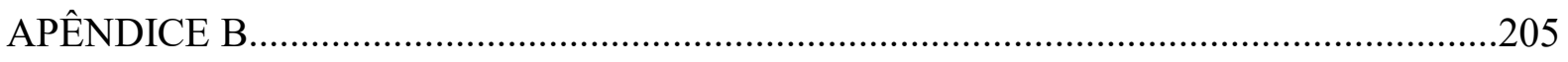

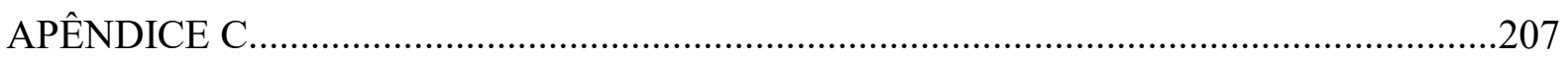

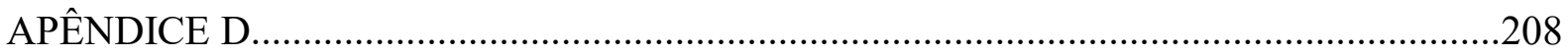

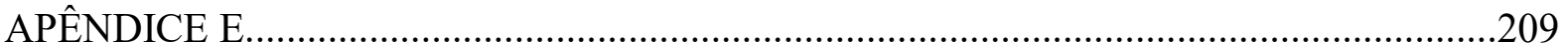





\section{LISTA DE ABREVIATURAS E SIGLAS}

ABIEC - $\quad$ Associação Brasileira das Indústrias Exportadoras de Carne ASSOCON - Associação Nacional de Confinadores

BC - Biocapacidade

BRIC - Brasil, Federação Russa, Índia e China

$\mathrm{Ca}-\quad$ Cálcio

CAK - $\quad$ Curva Ambiental de Kuznets

CEPEA - Centro de Estudos Avançados em Economia Aplicada

$\mathrm{CH}_{4}-\quad$ Gás metano

CNA - $\quad$ Confederação da Agricultura e Pecuária do Brasil

$\mathrm{CO}_{2}-\quad$ Dióxido de Carbono

COLAPA - Conselho Latino-Americano de Proteína Animal

CSR - Centro de Sensoriamento Remoto

EF - $\quad$ Ecological Footprint

EFC - $\quad$ Ecological Footprint de Consumo

EFE - $\quad$ Ecological Footprint de Exportação

EFI - $\quad$ Ecological Footprint de Importação

EFP - $\quad$ Ecological Footprint de Produção

EMBRAPA - Empresa Brasileira de Pesquisa Agropecuária

ESALQ - $\quad$ Escola Superior de Agricultura "Luiz de Queiroz"

FAO - $\quad$ Food and Agriculture Organization of the United Nations

FT - $\quad$ Ficha técnica

GEE - $\quad$ Gases do efeito estufa

GHA - Global Hectare

GLC - $\quad$ Global Land Cover

IFAD - International Fund for Agricultural Development

IIASA - $\quad$ International Institute for Applied Systems Analysis

iLPF - $\quad$ Sistema de integração lavoura-pecuária-floresta

IP - $\quad$ Intervalo de partos

IPCC - Intergovernmental Panel on Climate Change 


$\begin{array}{ll}\mathrm{K}- & \text { Potássio } \\ \text { LDC }- & \text { Least Developed Countries } \\ \mathrm{Mg}- & \text { Magnésio } \\ \mathrm{N}- & \text { Nitrogênio } \\ \mathrm{N}_{2} \mathrm{O}- & \text { Óxido Nitroso } \\ \mathrm{NCBA}- & \text { National Cattlemen's Beef Association } \\ \text { OCDE - } & \text { Organização de Cooperação e de Desenvolvimento Econômico } \\ \text { OMS - } & \text { Organização Mundial da Saúde } \\ \text { ONU - } & \text { Organização das Nações Unidas } \\ \mathrm{P}- & \text { Fósforo } \\ \text { PB }- & \text { Planetary Boundaries } \\ \text { PH - } & \text { Pegada Hídrica } \\ \text { PIB }- & \text { Produto Interno Bruto } \\ \text { PLS - } & \text { Partial Least Square } \\ \text { RBS - } & \text { Revisão Bibliográfica Sistemática } \\ \text { S - } & \text { Enxofre } \\ \text { SBA - } & \text { Sistema Brasileiro do Agronegócio } \\ \text { TALF - } & \text { Taxa de Alongamento de Folhas } \\ \text { TApF - } & \text { Taxa de Aparecimento de Folhas } \\ \text { UFMG - } & \text { Universidade Federal de Minas Gerais } \\ \text { USDA - } & \text { United States Department of Agriculture } \\ \text { WWF - } & \text { World Wide Funde for Nature } \\ & \end{array}$




\section{LISTA DE QUADROS}

Quadro 1: Equação do uso de Recursos Naturais.................................................................17

Quadro 2: Tecnologia em Pecuária de Corte..................................................................... 126

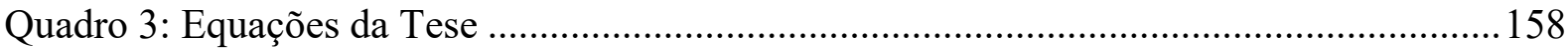




\section{LISTA DE TABELAS}

Tabela 1: Revisão Sistemática Ecological Footprint .......................................................... 48

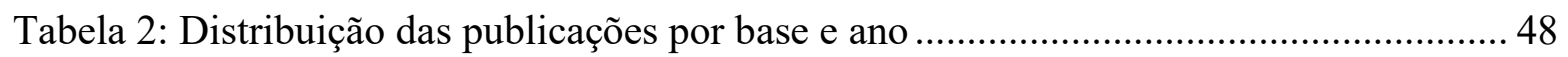

Tabela 3: Distribuição das publicações por ano, base e caso de estudo da EF .................... 49

Tabela 4: Distribuição das publicações por ano e metodologia aplicada da EF .................... 50

Tabela 5: Emissões de Metano e Óxido Nitroso Agrícolas (\% do total).................................. 62

Tabela 6: Contribuição da Agricultura para emissão de gases e outras emissões.................. 62

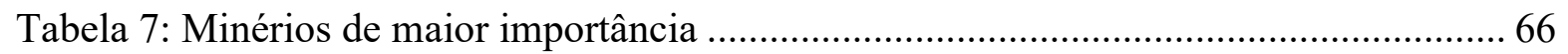

Tabela 8: Balanço da Pecuária Bovina Mundial ................................................................... 73

Tabela 9: Balanço da Pecuária Bovina de Corte no Brasil.................................................... 74

Tabela 10: Estrutura mínima de um rebanho de cria para produção .................................... 81

Tabela 11: Índices Zootécnicos de Produtividade da Pecuária de Corte............................... 85

Tabela 12: Rebanho Bovino - por categoria animal (Milhões de animais) ........................... 88

Tabela 13: Emissões de $\mathrm{CH}_{4}$, em gramas por dia, acumulado até abate .............................. 99

Tabela 14: Ações, Causas e Consequências de ações humanas ao Meio Ambiente ............ 108

Tabela 15: População mundial estimada e projetada ....................................................... 111

Tabela 16: Expectativa de vida mundial e projetada....................................................... 112

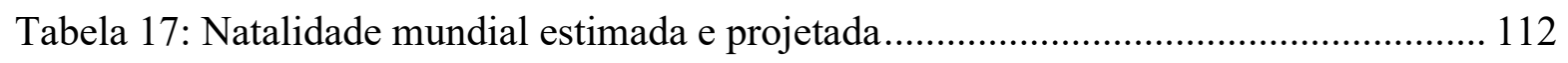

Tabela 19: Consumo de alimento per capita (kcal/pessoa/dia) ....................................... 128

Tabela 20: Estimativa e projeção do consumo de alimentos - principais países.................. 130

Tabela 21: Estimativa e projeção do consumo de alimentos - países em desenvolvimento 131

Tabela 22: Consumo Mundial de Carne Bovina (2011).................................................... 151

Tabela 23: Produção Mundial de Carne Bovina (2011)................................................... 154

Tabela 24: Regressão Múltipla - Consumo per capita e Pib per capita (1980-2011)........ 156

Tabela 25: Matriz Morfológica dos Cenários para 2040 ................................................. 161 


\section{LISTA DE FIGURAS}

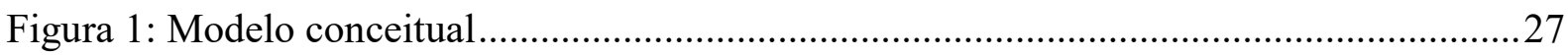

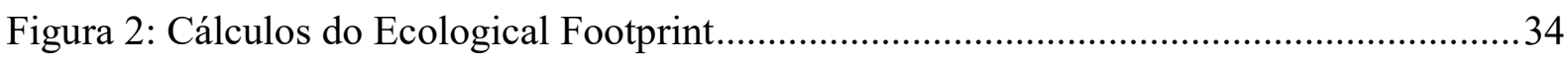

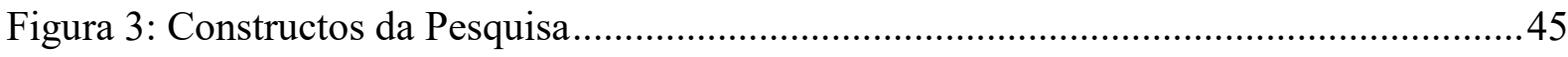

Figura 4: Relatório Mundial de Anos de Expectativa de Vida adquiridos (1990-2012).........58

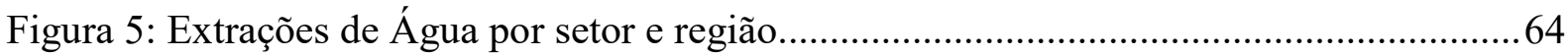

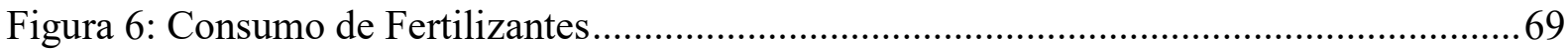

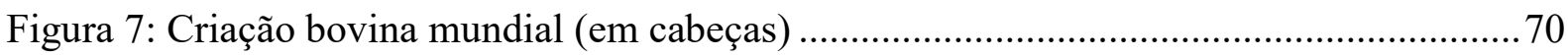

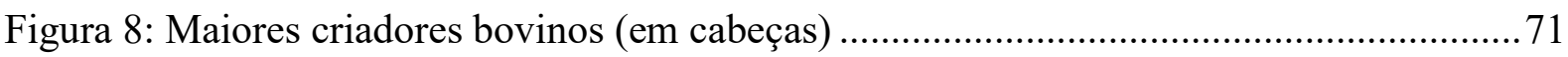

Figura 9: Produção de carne bovina (em toneladas)............................................................. 71

Figura 10: Maiores produtores de carne bovina (em toneladas) .......................................... 72

Figura 11: Perfil Brasileiro de Produção Bovina...................................................................... 73

Figura 12: Fluxograma de Etapas na Produção Pecuária Bovina.............................................80

Figura 13: Rendimento em Proporção de Rebanho de Cria .................................................... 82

Figura 14: Eficiência das vacas de descarte no sistema de cria..............................................83

Figura 15: Evolução da unidade animal por hectare nos estados da Amazônia - 1987/2013 ..84

Figura 16: Contribuição de países ao consumo de água mundial ........................................... 90

Figura 17: Consumo de água na produção industrial de alimentos ........................................91

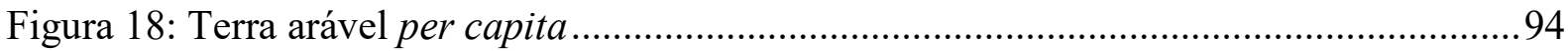

Figura 19: Previsão de Produção e Comércio Mundial Pecuarista em 2013 .......................... 102

Figura 20: Produção por grupo de Commodities e região em 2007 (milhões de toneladas) ... 104

Figura 21: Perda e Desperdício (per capita) de alimento por região e fase em 2007 ............ 104

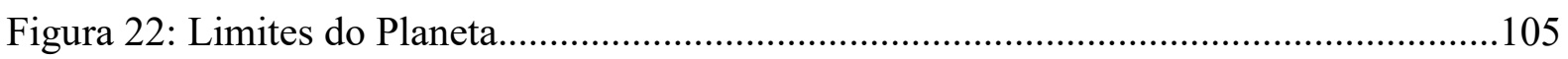

Figura 23: População Mundial: Rural e Urbana .................................................................. 111

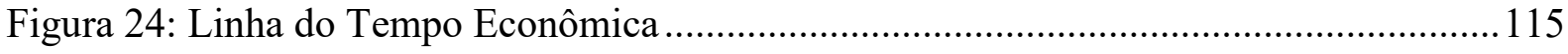

Figura 25: Comparação do PIB Agronegócio com o PIB Total Brasileiro ............................... 120

Figura 26: Participação do Agronegócio no PIB Brasileiro ..................................................... 121

Figura 27: Participação de cada segmento no PIB do Agronegócio Brasileiro........................ 121

Figura 28: Participação da Pecuária no PIB do Agronegócio Brasileiro ............................... 122

Figura 29: Pirâmide da Alimentação Saudável ................................................................... 127

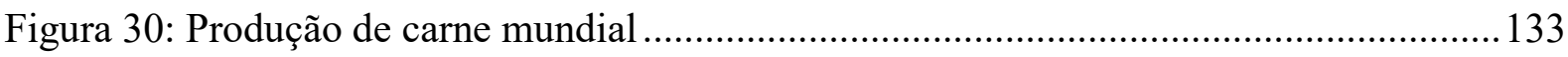


Figura 31: Projeção do Consumo Mundial de Carne Bovina ................................................ 134

Figura 32: Projeção do Consumo Per Capita de Carne Bovina no Brasil............................. 134

Figura 34: PH de consumo nos Estados Unidos em diferentes dietas (1996-2005) .............. 136

Figura 35: Tendência Global de Consumo em função do Pib per capita ................................ 157 


\title{
INTRODUÇÃO
}

\begin{abstract}
"A humanidade corre numerosos riscos que o naturalista e o biólogo são os primeiros a perceber, quando ainda escapam ao olhar da maioria dos homens. É, portanto dever do sábio tocar a campainha de alarme, ao invés de limitar-se, como é seu costume, à investigação dos fenômenos recém-descobertos". (LORENZ, 1974 p.5)
\end{abstract}

Durante a Pré-história, especificamente no período Paleolítico $(4,4$ milhões a.C. até 10.000 a.C.), o homem era nômade e dependia do que localizava para se alimentar, sobretudo plantas ou parte delas, como frutos e raízes. Durante o período Neolítico (12.000 a.C. a 4.000 a.C.), o fogo foi descoberto e junto com ele houve criações e descobertas de instrumentos de caça. Isso possibilitou a inclusão da carne animal como um item de consumo na alimentação. Para tal, o homem passou a domesticar animais para o seu próprio consumo e deu início a um processo que, depois de graus de evolução passou a ser conhecido como a agricultura. A partir disso, a agricultura passou a mudar não apenas hábitos alimentares, mas também a civilização humana, trazendo aos homens a necessidade de abandono da vida nômade e mudança para uma vida mais centralizada (em forma de aldeias e futuramente cidades) para o plantio e cultivo de alimentos. (DE CHARDIN, 2005 p.235; LOPES, K. R. F., 2010 p.20).

Durante os 8.500 anos que se seguiram, a agricultura evoluiu de forma lenta, por meio de tentativa e erro para produção de alimento e fibras. Ferramentas foram substituídas para que o trabalho se tornasse mais eficiente, mas o trabalho ainda se mostrava lento. Nos séculos $18 \mathrm{e}$ 19 a inovação agrícola evoluiu, iniciando com inventos que permitiam maior eficiência, organização e rapidez no plantio, como a primeira semeadeira mecânica. Durante o século 20, novos avanços tecnológicos fizeram com que a agricultura avançasse: máquinas (que substituíam equipamentos tradicionais), uso de fertilizantes, pesticidas e sementes aprimoradas. (MONSANTO, 2015).

Do início da agricultura até meados do século passado, o sistema de produção de alimentos predominante era baseado em pequenas propriedades familiares quase autossuficientes, na chamada "Pecuária de Corte". Os vegetais cresciam em hortas e pomares domésticos, lado a lado com a criação de cabras, galinhas e bovinos, que forneciam leite, ovos e carne. Os grãos 
eram triturados em moinhos de pedra e consumidos na forma integral, preservando as fibras e os benefícios naturais. (DE CHARDIN, 2005 p.236-240).

Porém mudanças ocorreram após a Segunda Guerra Mundial, impelidas por uma nova imagem rural e uso de tecnologias que ajudam a tecnificar a pecuária de corte. Uma dessas mudanças ocorreu no controle e na regulamentação da produção e importação de alimentos nos Estados Unidos. Foi desenvolvido um modelo alimentício liberal produtivista chamado "americano", que foi estabelecido rapidamente também na América Latina, Ásia e África, que dependia muito da produção de carne bovina e isso criava um incentivo para a produção industrial do gado e dos cultivos destinados à sua alimentação. Com a implantação desse modelo, sob o ponto de vista de produção, a agricultura sofreu duas mudanças fundamentais: a alteração de um modelo de grãos mistos e produção de gado para um regime especializado em grãos e operações intensivas de criação de gado, trazendo consequências ecológicas. (BELIK; MALUF, 2000).

Por outro lado, é possível observar outro elemento que pode também contribuir para que a pecuária bovina de corte adquira uma operação intensiva a cada ano - o aumento da população. Observa-se que entre 1900 e 2012, a população mundial cresceu de 1,6 bilhões para mais de 7 bilhões. (WORLD BANK, 2014h). À medida que as cidades cresciam, as lavouras foram deslocadas para lugares mais distantes dos centros urbanos, o que tornou necessária a construção de ferrovias e estradas para possibilitar o transporte de alimentos. Os vegetais e outros alimentos frescos cederam seu espaço no comércio e na mesa das pessoas para os produtos que podiam ser transportados com maior facilidade e que duravam mais tempo. Durante o século XX, o consumo de alimentos industrializados foi intensificado, devido a mudanças comportamentais e rotineiras ao estilo de vida sofridas pela população. Porém mesmo contemplando mudanças comportamentais, a produção agrícola foi impelida a aumentar seu nível de produção e incluir em seu modelo de negócio técnicas que contemplassem o cultivo de uma variedade de alimentos e abastecimento fresco e contínuo. (MONSANTO, 2015).

Com base nos fatos expostos até o momento, surge um raciocínio em outra vertente. Com a população mundial prevista para chegar a 9 bilhões de pessoas durante o século 21 (FAO, 2013), a demanda para a produção de alimentos, especialmente na pecuária, aumenta e para isso, o consumo de recursos naturais utilizados na produção e cultivo de alimentos também tende a aumentar de forma consequente. E devido à limitação de alguns desses recursos, a tendência é de que ocorra a intensificação desse esgotamento, agravado pelo aumento da poluição, disputas por recursos e as consequências de uma atmosfera que se aquece rapidamente 
pelas emissões de gases do efeito estufa. Todos estes fatores ainda podem produzir impactos econômicos, afetando significativamente o Produto Interno Bruto - PIB mundial. Todos esses efeitos serão notados de forma gradual com acumulado efeito para gerações vindouras. (MEADOWS, D.; RANDERS; MEADOWS, 2004 p.53-54).

No atual cenário global, realizar uma produção de carne bovina sustentável pode resultar em generosos e positivos frutos para a mitigação dos efeitos nocivos ao meio ambiente. Isso pode ser obtido por meio da conservação apropriada de água e solo, adoção de tecnologias de baixa emissão de gases do efeito estufa e que permitam a integração da lavoura-pecuária-floresta, adequado manejo da produção, colheita e armazenamento adequado e suficiente da produção colhida. Porém uma produção de carne bovina sustentável é reconhecida por muitos produtores como um desafio distante da real concretização, especialmente acentuado pelas tendências da necessidade de aumentos da produção. (MONSANTO, 2015).

Segundo dados da FAO (2014a) a população mundial passará a se alimentar cada vez melhor até 2030, com 3050 quilocalorias diárias disponíveis per capita, comparado com as 2360 quilocalorias diárias disponíveis per capita na década de sessenta e com as 2800 disponíveis atualmente. Essa mudança reflete, sobretudo, o aumento do consumo em muitos países em desenvolvimento, onde a média ficará em torno de 3000 quilocalorias per capita em 2030. Esse aumento do consumo gera uma tendência à obesidade (ou sobrepeso). A Organização Mundial de Saúde - OMS aponta a obesidade como um dos maiores problemas de saúde pública no mundo. A projeção é que, em 2025, cerca de 2,3 bilhões de adultos estejam com sobrepeso; e mais de 700 milhões, obesos. (ABESO, 2015; CARVALHO, E. O.; ROCHA, 2011).

Preocupações são expressas de que a agricultura poderá, em um futuro não muito distante, não ser capaz de produzir os alimentos necessários para alimentar uma crescente população mundial com níveis suficientes para levar uma vida saudável e ativa. No ano de 1700 , apenas $7 \%$ da superfície terrestre era utilizada para a agricultura. Atualmente essa área soma mais de $40 \%$. No entanto apenas uma parte restante da terra é atualmente adequada para o cultivo. (FAO, 2014a). Uma segunda preocupação é com o meio ambiente. De acordo com a FAO (2013), a saúde do planeta, a saúde e a segurança alimentar futura humana dependem da maneira como se lida com o planeta e assegurar o bem-estar é sinônimo de respeito pelo meio ambiente, para que a prosperidade sustentável a longo-prazo seja uma realidade para a humanidade. Dessa forma, a agricultura enfrenta uma escolha: por um lado a necessidade de produção contínua de 
alimentos, e por outro lado, a necessidade de conservação dos recursos naturais limitados tendo em vista futuras gerações humanas.

Assim, é possível presumir que mudanças sejam prudentes, contemplando as consequências já abordadas: mudança nos processos de cultivo e produção de alimentos (em especial na pecuária) e mudanças nos padrões de produção e consumo de alimentos, ambas visando uma redução na extração de recursos naturais. (MORILHAS; WECHSLER; KRUGLIANSKAS, 2007; QUIRINO; IRIAS; WRIGHT, 1999 p.32-33). Pesquisas com a finalidade de identificar o limite dos recursos naturais do planeta foram realizadas, fazendo uso do indicador Ecological Footprint (REES, WILLIAM; WACKERNAGEL, 1996; WACKERNAGEL; YOUNT, 1998), porém nelas não foi identificado um indicador de produção e consumo sustentável de alimentos abrangente (ou específico para pecuária bovina de corte) que contemple o consumo atual, o crescimento futuro e as variáveis que o influenciam. Com todos esses raciocínios apresentados, cria-se o panorama que fundamentou a pergunta chave desta pesquisa: Considerando-se que alguns recursos naturais do planeta Terra são finitos e não renováveis, quais cenários plausíveis de produção e consumo global sustentável de carne bovina podem ser projetados para 2040?

\section{$1.1 \quad$ Objetivos}

\subsubsection{Geral}

A partir do contexto apresentado até aqui, considerou-se como principal objetivo dessa pesquisa: A proposição de um modelo prospectivo com cenários globais para identificação de um padrão sustentável de produção e consumo de carne bovina pela população global para 2040, com base nos recursos naturais disponíveis e tendências sociais, econômicas e tecnológicas futuras.

O termo padrão, nessa pesquisa, se refere ao seu caráter etimológico original (do latim regula, vara de medida). De acordo com HOUAISS; VILLAR (2001), o termo padrão pode ser definido como a "base de comparação, algo que o consenso geral ou um determinado órgão oficial consagrou como um modelo aprovado ou ideal ". E o termo sustentável, nesta pesquisa, se refere ao seu caráter etimológico original (do latim sustentare). De acordo com (HOUAISS; 
VILLAR, 2001) o termo sustentável pode ser definido como "que pode ser sustentado, passível de sustentação ou suportável".

Dessa forma, "o padrão sustentável” utilizado como base nesta pesquisa será a metodologia Ecological Footprint (REES, WILLIAME, 1996), que trata-se de uma contabilidade ambiental, expressada em hectares globais - Gha, que contabiliza os recursos naturais (grãos e vegetais, carne, peixes, madeira e fibras, energia renovável etc.), segmentados em agricultura, pastagens, florestas, pesca, área construída, energia e absorção de dióxido de carbono $\left(\mathrm{CO}_{2}\right)$. Por meio dessa metodologia é possível avaliar a pressão do consumo das populações humanas sobre os recursos naturais e que permite comparar diferentes padrões de consumo e analisar a sua aderência a capacidade ecológica do planeta, visando à capacidade de atendimento sustentável a população prevista da Terra em um horizonte de 23-24 anos, juntamente com suas consequências futuras para as gerações vindouras.

O termo "pecuária bovina de corte" refere-se ao conjunto de atividades exercidas pelo pecuarista para a criação de bovinos que apresentam capacidade para a produção de carne. (TOYAMA; MARTIN; TACHIZAWA, 1978).

O termo "recursos naturais" se refere a elementos produzidos pela natureza (ar, água, rochas, minerais, solo, entre outros), que sofrem extração (de forma direta ou indireta) e são processados para a sobrevivência, civilização e conforto da humanidade. (SKINNER, 1996).

\subsubsection{Específicos}

Para que o objetivo geral fosse atingido, compreendeu-se que as seguintes etapas deveriam ser cumpridas, como objetivos específicos:

1. Caracterização dos principais recursos naturais relacionados à produção de carne bovina;

2. Caracterização das variáveis fundamentais associadas à evolução da produção e consumo de carne bovina;

3. Identificação e análise de indicadores sociais, econômicos e de sustentabilidade, juntamente com suas implicações para a produção e o consumo de carne bovina;

4. Identificação de tendências tecnológicas que possam afetar, diretamente ou indiretamente, a utilização de recursos naturais para a produção de carne bovina; 
5. Proposição de um modelo prospectivo que contemple cenários globais e identifique um padrão sustentável de produção e consumo de carne bovina, através da combinação do uso de recursos naturais, variáveis econômicas, tendências tecnológicas e padrões globais de consumo de alimentos;

6. Proposição de uma metodologia que promova a identificação de cenários futuros como apoio à tomadores de decisão em políticas públicas e estratégias tecnológicas e/ou de mercado para os negócios.

\subsection{Justificativa}

Podem ser considerados argumentos que fundamentaram a relevância desta pesquisa delineados nos seguintes aspectos:

Em primeiro lugar, recursos naturais são a fundação da prosperidade material de uma nação tanto atual como futura (BARNETT; MORSE, 1963 p.20) e em vista disso, a raça humana tem aprendido a modificar e explorar o meio ambiente para sua vantagem de diferentes formas. Há linhas de estudo que defendem que o homem não entende que é parte da natureza e não proprietário dela, que seu poder sobre ela não é baseado no controle e que estabilizar ou reduzir o consumo de recursos naturais per capita não é o suficiente. (EHRLICH, P.R.; EHRLICH; HOLDREN, 1973 p.4 e 11). Em contrapartida, diferentes autores acreditam que o uso de recursos naturais deve ser explorado como fator de competitividade e especialmente como item gerador de vantagem competitiva de nações ou organizações. (PORTER, 1998).

O uso crescente de recursos naturais é bastante acentuado pelo aumento do consumo. Os problemas de recursos e ambiente são às vezes até fáceis de descrever de forma quantitativa. Porém o ponto fundamental é que os fatores que contribuem para o crescimento do consumo de recursos e degradação ambiental são multiplicados, em vez de adicionados. (EHRLICH, P.R. et al., 1973 p.206; REILLY, 2012) Essa ideia é expressa pela equação descrita no quadro 1: 
Consumo de Recursos $=$ População $\times$ Consumo por pessoa

Ou de uma forma mais complexa:

$$
\mathrm{I}=\mathrm{P} * \mathrm{Ci}^{*} \mathrm{Ip}
$$

Impacto ambiental $(I)=$ População $(P) \times$ Consumo de produtos por pessoa (Ci) $x$ Impacto ambiental pela quantidade de cada item consumido (Ip)

Fonte: elaborado pela autora com base em EHRLICH, P.R. et al. (1973)

Além dos efeitos mencionados, há diferentes tipos de resíduos que são gerados pela sociedade moderna, os quais têm gerado possíveis efeitos ao ambiente. As forças externas do mercado contribuem para essa excessiva geração. A economia sugere a necessidade de equilíbrio ou o chamado General Equilibrium Model of Resources entre as variáveis de rendimento global, padrões de consumo, possibilidades tecnológicas de produção, o que resultaria em uma interrelação do mercado através da economia. Um modelo macroeconômico criado por Leontief propôs um planejamento futuro relacionado à emissão de resíduos e seus efeitos. Por meio desse modelo, ele concluiu que a base para um planejamento equilibrado é o tamanho da população e os níveis de demanda de produtos. (KNEESE, 1977 p.55-67).

Há autores que avaliam que a mudança ambiental é impulsionada pela produção versus tendências de consumo globais. E para se entender isso, é necessária a construção de elos mais fortes entre as ciências naturais e as ciências sociais a fim de se compreender as mudanças ambientais globais e para se elaborar políticas públicas que respondam a elas de uma maneira efetiva. (STERN, P. C.; YOUNG; DRUCKMAN, 1993 p.6). Os estudos da mudança global tipicamente fazem pressuposições, pelo menos, a respeito de três aspectos do comportamento humano: o que as pessoas estão fazendo que pudesse afetar o meio ambiente (e como esse comportamento pode modificar com o passar do tempo); como as pessoas são afetadas pelas mudanças no meio ambiente (e como a sensibilidade das mesmas a tais mudanças pode variar com o tempo); e quais informações as pessoas usam (ou poderiam usar no futuro) ao fazerem escolhas sobre suas relações com o meio ambiente. (STERN, P. C. et al., 1993 p.165). Com base nisso, é importante avaliar: 1) como as grandes transformações sociais em longo prazo afetam o meio ambiente global; 2) a proporção em que as transformações sociais podem ser invertidas, diminuídas ou redirecionadas; 3) condições sob as quais tais transformações de trajetória são possíveis. (STERN, P. C. et al., 1993 p.174). 
A relevância científica do tema, por sua vez, está diretamente relacionada ao desenvolvimento de um modelo prospectivo com cenários globais de produção sustentável de carne bovina, contemplando diferentes variáveis e que culmine em um padrão sustentável de produção e consumo global. Apresenta como diferencial ser um modelo único e que poderá futuramente ser empregado como indicador sustentável em diferentes ambientes. Além disso, essa pesquisa demonstra a possibilidade do uso de cenários prospectivos de longo prazo em diferentes setores, os quais evidenciam os impactos e as escolhas de políticas públicas e estratégias tecnológicas para que empresas e instituições possam trabalhar em prol de um futuro sustentável.

A busca de indicadores de desenvolvimento sustentável é um tema recorrente na literatura de ciência ambiental, ecologia industrial e gestão ambiental e política. Cientistas têm investigado componentes afim de selecionar indicadores, procedimentos de agregação e pesos. Isso deu origem a muitos índices ambientais agregados, os quais, infelizmente, nem sempre apontam na mesma direção. Possivelmente, o esforço mais influente para resolver ou contornar problemas de agregação e ponderação foi a metodologia Ecological Footprint - EF, que tem por objetivo responder a grande questão de "quanto o planeta precisa para repor todos os recursos em prol do consumo humano". Ela foi proposta há cerca de 18 anos, em forma de abordagem e método, que visa determinar o grau de (in) sustentabilidade de atividades e regiões / países. (REES, W. E., 1992 p.124-126).

A EF compara a biocapacidade descrita por vários recursos ecológicos (agricultura, pastagem, florestas, pesca, área construída, energia e área necessária para a absorção de dióxido de carbono) com diferentes classes de consumo (alimentos, moradia, mobilidade e transporte, bens e serviços, governo e infraestrutura) e tem como objetivo avaliar a pressão do consumo das populações humanas sobre os recursos naturais e tornou-se uma importante ferramenta de gestão ambiental e urbana que permite apontar ações de mitigação que podem ser feitas visando à redução de impactos. A EF de um país, estado, cidade ou pessoa corresponde ao tamanho das áreas produtivas terrestres e marinhas necessárias para sustentar determinado estilo de vida. É uma forma de traduzir, em hectares, a extensão de território que uma pessoa ou uma sociedade utiliza para morar, se alimentar, se locomover, se vestir e consumir bens de forma geral. (REES, WILLIAM; WACKERNAGEL, 1996 p.227-228). 
Uma vez que a metodologia aplicada na EF foi definida como base para o desenvolvimento dessa pesquisa, foi realizada uma Revisão Bibliográfica Sistemática - RBS para identificar as diferentes aplicações da metodologia em pesquisas científicas realizadas na última década (considerando que essa parte da pesquisa foi realizada durante o ano de 2015). A RBS desenvolvida foi detalhada mais a frente, no capítulo destinado a descrição da metodologia da pesquisa.

\subsection{Contribuições da pesquisa}

Do ponto de vista teórico, este trabalho preencheu uma lacuna não explicada nas pesquisas analisadas com aplicação da EF, com o desenvolvimento de uma metodologia de pesquisa inédita, seguido pela criação de um modelo que contemple o uso de recursos naturais para produção de alimentação de carne bovina global, avaliando juntamente variáveis ecológicas, econômicas e tecnológicas. Além disso, possui o diferencial de analisar padrões sustentáveis e fazer a junção em um modelo com cenários prospectivos.

A sustentabilidade é encarada como um assunto de suma importância, e em especial o desenvolvimento sustentável tem sido defendido como a solução para uma grande gama de problemas globais. (ELKINGTON, 2012 p.52). Segundo Herman Daily (ELKINGTON, 2012 p.92-93), uma sociedade sustentável precisa atender a três condições: 1) suas taxas de utilização de recursos naturais não devem exceder suas taxas de regeneração; 2) suas taxas de uso de recursos naturais não devem exceder a taxa pela qual a renovação sustentável dos substitutos é desenvolvida; 3) suas taxas de emissão de poluentes não devem exceder a capacidade de assimilação do meio ambiente.

Porém, capitalismo e sustentabilidade não compõem uma fácil aliança. O capitalismo, sendo ele de qualquer tipo, é um sistema econômico e político, no qual os proprietários individuais de capital são, de forma relativa, livres para dispor dele da maneira que o desejarem, "em especial" para seus próprios interesses. (ELKINGTON, 2012 p. 56-58).

Em vista disso, para a prática social, a pesquisa contribuiu para uma reflexão diferenciada com respeito ao futuro do planeta. Para isso, se faz necessário o entendimento de como promover uma sociedade sustentável que visualize o presente e o futuro com a mesma objetividade. Em algumas pesquisas do tema foi salientado que os resultados dos estudos não transferem uma 
conscientização ambiental de produção e consumo pela sociedade (GIAMPIETRO; SALTELLI, 2014; KITZES et al., 2008; VAN DEN BERGH; GRAZI, 2014), especialmente porque os resultados são transmitidos em uma linguagem que não transmite a ideia de que alguns dos recursos naturais são finitos. Dessa forma, a pesquisa visou, especialmente por meio do modelo prospectivo e seus cenários, evidenciar resultados do uso de recursos naturais para produção e consumo de alimentos pecuaristas, objetivando uma reflexão das organizações e dos cidadãos no tocante a necessárias ações e/ou mudanças comportamentais visando o futuro sustentável do planeta para futuras gerações.

Como contribuição prática, a pesquisa contribuiu para demonstrar como a análise de cenários prospectivos permite aos tomadores de decisão vislumbrarem as opções estratégicas possíveis e necessárias para assegurar a perenidade dos negócios, e as opções tecnológicas e de mercado necessárias para tanto. Além disso destacou a proposição de novos focos de atuação para as empresas atuantes no setor de pecuária bovina de corte.

\subsection{Modelo conceitual e escopo da pesquisa}

Por se tratar de uma pesquisa que discute um fenômeno complexo - o uso de recursos naturais para um nível de produção e consumo sustentável de alimentos pecuaristas pela população mundial - torna-se necessário que seu escopo seja definido de maneira clara (SEKARAN, 2006 p.90-91), a fim de que seja orientada a elaboração do trabalho e atenuação de eventuais divergências de pontos de vista no processo de análise. Por essa razão, foi desenvolvido o modelo conceitual exposto na figura 1 .

O modelo conceitual da pesquisa, ilustrado na figura 1, indica o processo realizado na alimentação humana, de forma contínua, o qual consome recursos naturais, que podem sofrer determinado nível de degradação ambiental - mas pode ser equilibrado para que haja um nível de produção sustentável de alimentos e seja possível vislumbrar cenários de consumo sustentável. 
Figura 1: Modelo conceitual

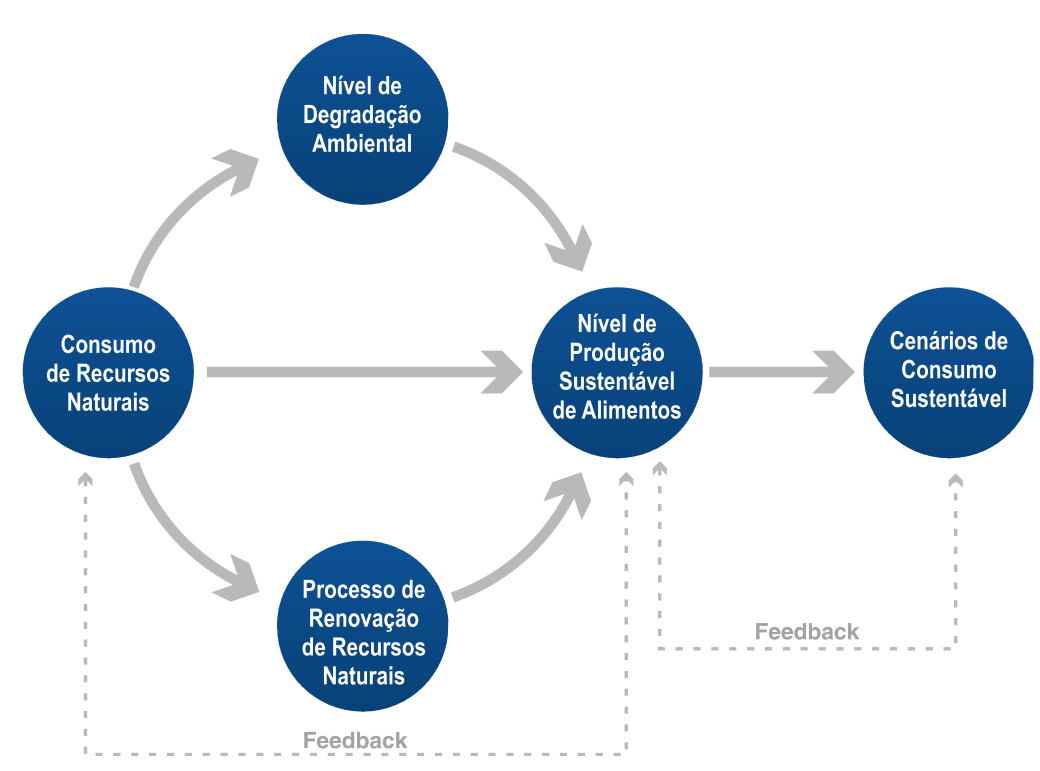

Fonte: Elaborada pela autora

Considerando que o uso de recursos naturais é bastante diversificado, qualquer pesquisa que trate desta temática tende a ser bastante complexa. Assim, definiu-se o foco em cinco vertentes principais, sendo elas:

a) Consumo de recursos naturais utilizados para produção pecuarista;

b) Degradação ambiental sustentável;

c) Produção pecuária sustentável;

d) Renovação sustentável de recursos naturais;

e) Consumo de alimentos pecuários pela população global (considerando indicadores econômicos, populacionais e tecnológicos).

\subsection{Estrutura da pesquisa}

Este trabalho foi concebido e estruturado em sete capítulos principais, além de seus elementos pré e pós-textuais, que foram acrescentados ao final do trabalho. A descrição de cada capítulo obedece à seguinte estrutura:

a) O Capítulo 1 contém os aspectos introdutórios à pesquisa, a saber: a contextualização do problema de pesquisa; a descrição de seus objetivos; a justificativa da pesquisa; as contribuições pretendidas, tanto do ponto de vista teórico como da prática; o escopo da pesquisa e seu modelo conceitual. 
b) Os Capítulos 2-7 têm por objetivo apresentar o referencial teórico utilizado nesta pesquisa. Também é papel desses capítulos apresentar a teoria que será utilizada como referencial para a análise do modelo proposto.

c) O Capítulo 8 contém os constructos definidos na pesquisa.

d) O Capítulo 9 descreve os aspectos metodológicos da pesquisa, como classificação, técnicas adotadas e procedimentos empregados.

e) O Capítulo 10 contêm as descrições do modelo contemplado nesta pesquisa, bem como as análises realizadas a partir do levantamento de dados secundários, devidamente definidos nos Capítulos 2-7, juntamente com os constructos definidos no capítulo 8 , incluindo as técnicas, procedimentos e etapas devidamente descritas no Capítulo 9.

f) O Capítulo 11 descreve os cenários contemplados das simulações do modelo criado (explicitado no capítulo 10).

g) O Capítulo 12, por sua vez, encerrará os elementos textuais apresentando as considerações finais da pesquisa, por meio da confrontação dos objetivos apresentados no Capítulo $1 \mathrm{com}$ as análises realizadas no Capítulo 10 e 11, bem como as eventuais limitações encontradas no decorrer do processo de pesquisa e elaboração deste trabalho, e as sugestões para pesquisas futuras.

h) E, finalmente, o trabalho será encerrado com a apresentação dos elementos pós-textuais, dentre os quais as referências utilizadas e eventuais apêndices e anexos, tais como instrumentos utilizados para a coleta de dados, além de outros que forem considerados relevantes. 


\section{MODELOS E PROCEDIMENTOS METODOLÓGICOS}

Conforme já explicitado no capítulo anterior, a pesquisa utilizou como base a metodologia Ecological Fooprint, com as devidas adaptações, seguida pela aplicação de Cenários Prospectivos. Em vista disso, este capítulo tem como premissa a abordagem dos métodos utilizados como base da pesquisa e por fim a metodologia desenvolvida nessa pesquisa, dividida através de etapas e procedimentos.

\subsection{Metodologia Ecological Footprint}

A busca de indicadores ou de parâmetros de desenvolvimento sustentável é um tema recorrente na literatura de ciência ambiental, ecologia industrial e gestão ambiental e política. (HUYSMAN et al., 2015; JAKOB; EDENHOFER, 2014; JONES-WALTERS; MULDER, 2009; OJEDE; MUGERA; SEO, 2013). Cientistas têm investigado componentes afim de selecionar indicadores, procedimentos de agregação e pesos e isso deu origem a muitos índices ambientais agregados, os quais, infelizmente, nem sempre apontam na mesma direção. (CHAPAGAIN, ASHOK KUMAR, 2006; CHAPAGAIN, ASHOK K; HOEKSTRA, 2004; CHAPAGAIN, A. K.; ORR, 2009; HOEKSTRA; MEKONNEN, 2012; MEKONNEN, M.; HOEKSTRA, 2010; MEKONNEN, M. M.; HOEKSTRA, 2011; VANHAM; MEKONNEN; HOEKSTRA, 2013).

Por muito tempo o desenvolvimento era considerado sinônimo de crescimento econômico. Para o filósofo PINTO (2005), o crescimento econômico tem caráter quantitativo, conservador, meramente expansivo que favorece apenas uma minoria, diferente do desenvolvimento que é encarado como qualitativo e transformador da realidade, feito em progressão geométrica e que possui um papel universalmente libertador. Para VAN BELLEN (2005), o desenvolvimento sustentável envolve o crescimento econômico conjunto com justiça e oportunidades para todos os seres humanos do planeta, sem privilégio de algumas espécies, sem destruir os recursos naturais e sem ultrapassar a capacidade de carga do sistema.

Com base nisso, é possível dizer que a sustentabilidade possui um caráter dinâmico, explicitado 
por SACHS; VIEIRA; WEBER (2002) como um processo de mudança, no qual a exploração dos recursos, a dinâmica dos investimentos, e a orientação das inovações tecnológicas e institucionais são realizadas de forma consistente, considerando as necessidades tanto atuais quanto futuras do planeta.

Dentro dessa perspectiva, possivelmente, o esforço mais influente para resolver ou contornar problemas de agregação e ponderação econômica e ambiental através de indicadores foi a metodologia do Ecological Footprint - EF (ou a chamada Pegada Ecológica). Ela foi proposta há cerca de 18 anos, tanto como uma abordagem e um método, que visa determinar o grau de (in) sustentabilidade de atividades e regiões / países. (ODEGARD, INGRID YM RUTH, 2011; ODEGARD, I. Y. R.; VAN DER VOET, 2014).

A EF compara a biocapacidade descrita por vários recursos naturais (agricultura, pastagem, florestas, pesca, área construída, energia e área necessária para a absorção de dióxido de carbono) com diferentes classes de consumo (alimentos, moradia, mobilidade e transporte, bens e serviços, governo e infraestrutura) e tem como objetivo avaliar a pressão do consumo das populações humanas sobre os recursos naturais e tornou-se uma importante ferramenta de gestão ambiental e urbana que permite apontar ações de mitigação que podem ser feitas visando à redução de impactos. A EF de um país, estado, cidade ou pessoa corresponde ao tamanho das áreas produtivas terrestres e marinhas necessárias para sustentar determinado estilo de vida. É considerada uma forma de traduzir, em hectares, a extensão de território que uma pessoa ou uma sociedade utiliza para morar, se alimentar, se locomover, se vestir e consumir bens de forma geral. (REES, W. E., 1992 p.124-126).

A EF é popular, não só por que supostamente fornece um indicador geral para a pressão ambiental ou de impacto, mas também porque ela ressoa com a noção de que as atividades humanas não devem exceder a capacidade de assimilação do meio ambiente, identificando o impacto que as decisões cotidianas geram sobre o ambiente. (BORUCKE et al. (2013); (HERENDEEN, 2000).

Atualmente, a média da EF mundial é de 2,6 hectares globais por pessoa, enquanto a biocapacidade disponível para cada ser humano é de apenas 1,7 hectare globais. Isso coloca a humanidade em um grave déficit ecológico de 0,9 gha/cap, ou, expressado de outra forma, a humanidade consome um planeta e meio, excedendo assim a capacidade regenerativa do 
planeta em 50\%. Desde meados da década de 1980, a humanidade passou a consumir mais do que o planeta naturalmente oferece e se mantém acima do limite necessário de um planeta. Projeções para 2050 apontam que, se a humanidade continuar a proceder desta forma, uma maior capacidade ecológica será necessária para que seja mantido o mesmo padrão de consumo. A EF da humanidade mais que duplicou desde 1966 e atualmente está em 2,9 hectares globais por habitante, indicando que o consumo médio de recursos naturais pelo brasileiro está bem próximo da EF mundial. (VAN DEN BERGH; GRAZI, 2014 p.10).

Um exemplo disso é que em 1961 era preciso apenas 63\% da Terra para atender às demandas humanas. Porém, em 1975 já era necessário 97\% da Terra. Em 1980 se exigia 100,6\% de Terra, portanto, já se necessitava maior capacidade ecológica. Em 2005 já se contabilizava a cifra de $145 \%$ de Terra. Isso quer dizer que é preciso quase uma Terra e meia para estar à altura do consumo geral da humanidade. Em 2011 a humanidade se aproximou de 170\% de Terra. Portanto, próximo a dois planetas Terra. A seguir esse ritmo, as estatísticas indicam que no ano 2030 serão necessários pelo menos três planetas Terra iguais a este que a humanidade vive. Se hipoteticamente se quisesse universalizar para toda a humanidade o nível de consumo que os países ricos como os Estados Unidos, a União Europeia e o Japão desfrutam, biólogos e cosmólogos afirmam que, seriam necessários cinco planetas Terra, o que torna-se irracional. (WWF, 2014 p.32-33).

Especialmente sob o tema de alimentação e/ou agricultura, alguns modelos baseados na EF foram pesquisados para analisar o futuro dos alimentos. (AGOSTINHO; PEREIRA, 2013; BLAIR; SOBAL, 2006; CERUTTI et al., 2010; CERUTTI et al., 2011; CERUTTI et al., 2013; KISSINGER; FIX; REES, 2007; MÓZNER, 2014; SARAVIA-CORTEZ et al., 2013).

\subsubsection{Fundamentos}

A medição da EF é dividida em duas partes: a demanda sobre a natureza (ou Pegada Ecológica, EF) e a oferta ecológica (ou Biocapacidade, BC), estimada para um período de tempo definido. Do lado da demanda, há o recurso de utilização EF (áreas construídas, consumo de energia e recursos renováveis), que é expresso em unidades de espaço ou hectares globais. Do lado da oferta, BC agrega a produção de vários ecossistemas em uma determinada área (como por exemplo, de terras aráveis, pastagens, florestas ou mares produtivos). Os fatores de ponderação harmonizam influências ou componentes heterogêneos e os convertem em diferentes unidades: 
(toneladas ( $\mathrm{t}$ ) ou hectares (ha)) em unidades padronizadas (Hectares globais, gha). Cada hectare global equivale a uma quantidade igual de produtividade biológica. (LAZARUS et al., 2014; REES, W. E., 2001; SCHAEFER et al., 2006).

$\mathrm{O}$ principal objetivo da metodologia EF é responder à pergunta concernente a condição necessária para o consumo sustentável: "A demanda humana está dentro da capacidade regenerativa do planeta?". (KITZES; WACKERNAGEL, 2009; SCHAEFER et al., 2006; VAN DEN BERGH; GRAZI, 2014).

\subsubsection{Demanda sobre a natureza - EF}

A medida traduzida na EF é a produtividade dos recursos necessários durante o período de tempo especificado (por exemplo, um ano), o produto selecionado (por exemplo, culturas, produto animal e etc.) e o tipo de terra ligado (por exemplo, pastagens, pastagens, área de pesca). Em suma, a EF é uma medida do consumo (ou demanda) de recursos renováveis (culturas, produtos de origem animal, madeira e peixe), através do resultado do consumo de energia e o uso de áreas urbanizadas, convertidas em unidades produtivas padronizadas - global hectares - gha. (LAZARUS et al., 2014).

O fator de equivalência (em gha/ha) traduz um tipo de terra específico (como terra de cultivo ou floresta) em um hectare. Este fator de equivalência representa a produtividade potencial média do mundo de um dado bioprodutivo em relação à produtividade potencial média mundial de todas as áreas bioprodutivas. Por exemplo, a produtividade média das terras agrícolas é superior à produtividade média de todos os outros tipos de terras, que são convertidos, aplicando-se seu correspondente fator de equivalência para serem expressos em hectares globais. A equivalência é a mesma para todos os países, mas varia de ano para ano devido a mudanças na produtividade relativa dos tipos de ecossistemas ou de uso da terra por fatores ambientais (como padrões climáticos). (LAZARUS et al., 2014) Os fatores de equivalência são derivados do índice de adequação de Global Agro-Ecological Zones - GAEZ, que consiste em um Modelo Agrícola de Rendimento. (FAO; IIASA, 2000). 


\subsubsection{Biocapacidade - BC}

A Biocapacidade - BC é uma metodologia que responde à pergunta: "Quantos recursos renováveis têm sido disponibilizados pela capacidade regenerativa da biosfera (ou que são produzidos pelos vários ecossistemas)? (SCHAEFER et al., 2006).

$\mathrm{BC}$ representa a maior parte da capacidade regenerativa da biosfera. É um agregado de produção de vários ecossistemas numa determinada área (por exemplo, de terras aráveis, pastagens, florestas, mar). Alguns deles também podem consistir em terras construídas ou degradadas. $\mathrm{O}$ BC da Terra aumenta com uma maior produtividade biológica e com maior produtividade por unidade de área. (LAZARUS et al., 2014; WWF, 2011;2014;2015).

Em 2004, a Terra tinha 11,4 bilhões de hectares de terra e mar biologicamente produtivos para aproximadamente um quarto da superfície do planeta (2,3 bilhões de hectares de água oceânica e terrestre, 1,5 bilhão de hectares de terras cultivadas, 3,5 bilhões de hectares de pastagens, 3,8 bilhões de hectares de florestas no planeta Terra e 0,2 mil milhões de hectares de terrenos urbanos). Com base nisso, é de vital importância relembrar que um hectare (gha) é uma unidade de terra que contém a produtividade média da Terra, ou seja, é uma unidade universal biologicamente produtiva, que inclui a sua capacidade de absorção de resíduos. (LAZARUS et al., 2014; SCHAEFER et al., 2006).

É válido ressaltar que a biocapacidade não depende apenas das condições naturais, mas também das práticas prevalecentes de uso da terra (por exemplo, agricultura, silvicultura e etc.). (GALLI et al., 2014) É possível identificar no fator de rendimento específico de um país discrepâncias, que podem ser atribuídas a diferentes níveis de produtividade de um tipo de terra e avanços tecnológicos. (KAIMOWITZ, D.; SMITH, 2001). Dessa forma, cada país pode ter seu próprio conjunto de fatores de rendimento que sofre oscilações ano a ano. E novamente, o fator de equivalência (em gha / ha) traduz um hectare de um tipo de terra específico (como pastagens, áreas florestais, águas marinhas ou áreas construídas) em um hectare global. (LAZARUS et al., 2014; SCHAEFER et al., 2006).

\subsubsection{Cálculos}

Os cálculos da EF e BC são construídos pela combinação da EF e da BC (indicados na figura 2), transformando a abordagem em uma discriminação algébrica, na qual são empregados 
extensos conjuntos de dados, originados de estatísticas nacionais e organizações científicas como agências da Organização das Nações Unidas - ONU ou estatísticas anuais das áreas dos países na agricultura, florestas e energia. A produção interna e o comércio são considerados para o consumo (ou demanda final). As lacunas de dados são preenchidas e analisadas com a ajuda de uma variedade de organizações governamentais, acadêmicas ou privadas. A margem de erro dos cálculos EF e BC com base nas lacunas das fontes de dados é de difícil quantificação. (LAZARUS et al., 2014; SCHAEFER et al., 2006).

Figura 2: Cálculos do Ecological Footprint

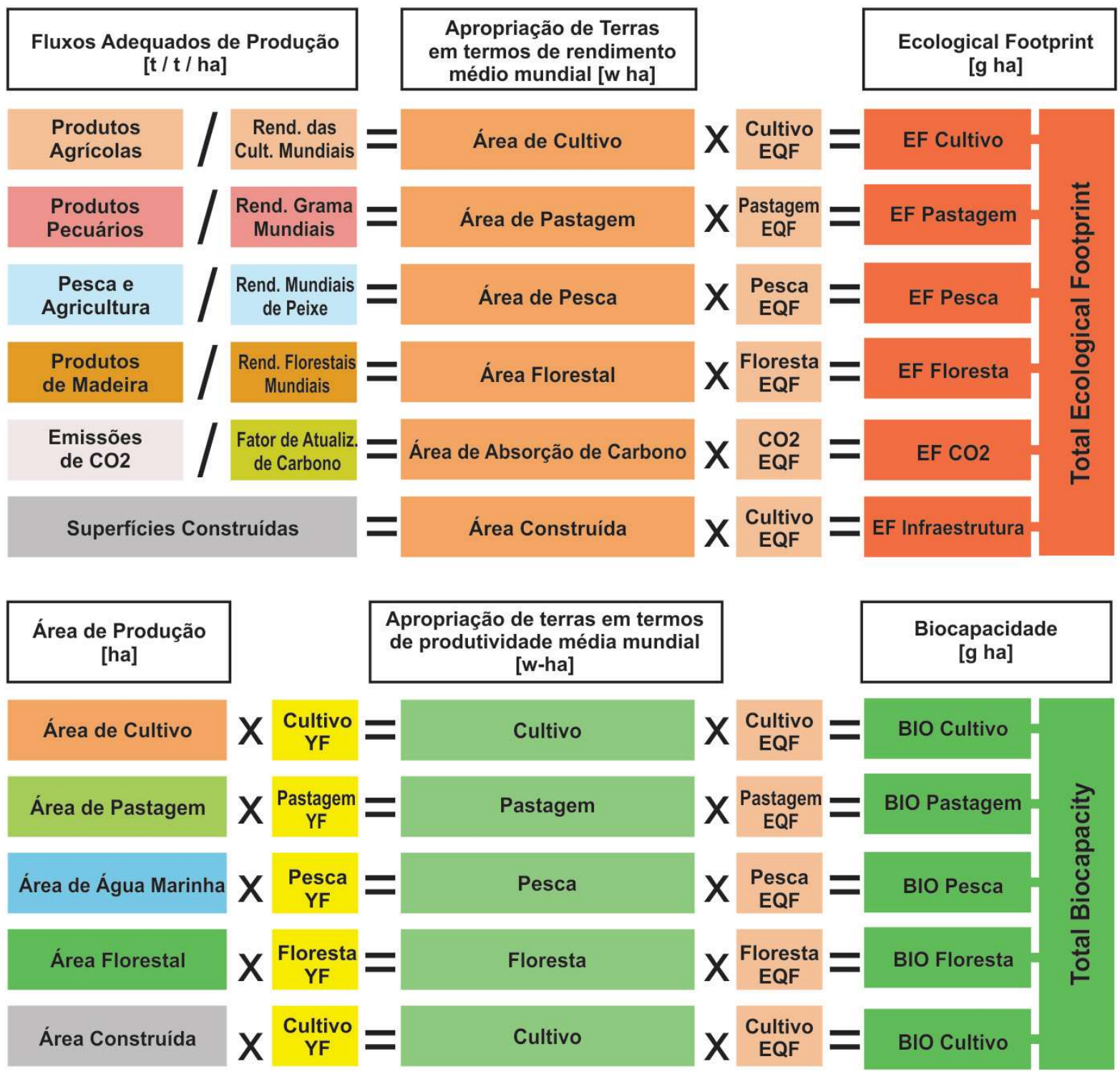

Fonte: (REES, WILLIAM; WACKERNAGEL, 1996 p.227-228)

Nos cálculos da EF realizados pela Global Footprint Network há diferentes planilhas parciais que consolidam a EF de cada país/região. (LAZARUS et al., 2014) Essas planilhas parciais resumem as EFs de Produção (EFP), Importações (EFI), Exportações (EFE) e Consumo (EFC). 
Existem sete planilhas no total: uma para cada um dos seis tipos de uso da terra; e uma para biocapacidade, que calcula a biocapacidade para cada tipo de uso da terra, com exceção do carbono (atualmente atribuído uma biocapacidade):

1. Carbono (Ef_Carbon): EF de carbono advindo da combustão de combustíveis fósseis e do comércio de eletricidade.

2. Terras de Cultivo: (Ef_Crop): EF de terras de cultivo incorporada em produtos agrícolas e em produtos resultados de gado e peixe (alimentos para forragem e peixe).

3. Pastagem: (Ef_Grazing): EF de grama para pastagem incorporada em produtos pecuários.

4. Áreas Marinhas: (Ef_Fish): EF de áreas marinhas incorporada em peixes e outros produtos aquáticos.

5. Florestas: (Ef_Forest): EF de produtos florestais incorporada em produtos florestais.

6. Infraestrutura: (Ef_Built): resume a EF associada à infraestrutura.

7. Biocapacidade (Biocap): área bioprodutiva de um país e a biocapacidade em cada um dos seis tipos de uso da terra.

Segundo LAZARUS et al. (2014), a EF de consumo é calculada de acordo com a equação $E F_{C}$ $=E F_{\mathrm{p}}+E F_{\mathrm{I}}-E F_{\mathrm{E}}$, onde:

$\mathrm{EF}_{\mathrm{C}}=\mathrm{EF}$ de consumo associada a um produto ou resíduos

$\mathrm{EFP}=\mathrm{EF}$ de produção associada a produto ou resíduo

$\mathrm{EF}_{\mathrm{I}}=\mathrm{EF}$ das importações associadas a produtos ou resíduos

$\mathrm{EF} E=\mathrm{EF}$ das exportações associadas a produtos ou resíduos

\subsubsection{Aplicações}

A Global Footprint Network (Organização sem Fins Lucrativos) é uma comunidade que tem por intuito estabelecer padrões internacionais para a metodologia da EF, a fim de estabelecê-la como indicador padrão de sustentabilidade.

As aplicações da EF variam do estudo da demanda de recursos a nível global, nacional a níveis regionais. Exemplos recentes de aplicações da EF a nível internacional são o "WWF - Living Planet Report 2014" (WWF, 2014) e o relatório "Living Forests Report 2011" (WWF, 2011). Exemplos de estudos da EF aplicados de forma nacional são: Exergy based Ecological Fooprint accounting for China" (SHAO; WU; CHEN, 2013), "Accounting for demand and supply of the 
biosphere's regenerative capacity: The National Footprint Accounts' underlying methodology and framework" (BORUCKE et al., 2013), "Ecological Footprint Time Series of Austria, the Philippines and South Korea for 1961-1999" (WACKERNAGEL et al., 2004).

\subsubsection{Limitações da EF e Planos de Ação na Pesquisa}

No entanto são identificadas por diferentes autores limitações na metodologia EF. Algumas dessas limitações seguem descritas, juntamente com as ações realizadas pela autora:

1. Ausência de robustez na política de dados e variáveis: visto que o uso de diferentes fontes de dados pode provocar alterações na escolha de variáveis, e/ou no sistema de ponderação, há necessidade de definição robusta para a seleção de dados. (SCHAEFER et al., 2006). A fim de minimizar essa limitação, para essa pesquisa foi utilizada uma única fonte de dados, a Global Footprint Network.

2. Componentes heterogêneos: Os cálculos de EF e BC agregam uma variedade de subcomponentes (consumo de alimentos, fibras, madeira, energia e uso predominante de terras) de acordo com a estimativa da biocapacidade. O fato de se obter um único valor como componente heterogêneo não garante que a interpretação seja realizada de forma simples. (SCHAEFER et al., 2006). Em vista dessa limitação, foi analisada a EF de apenas um ecossistema: Ef_Grazing ou Pastagem - para que diminuísse a possibilidade de agregação de componentes não relacionados ao objeto de estudo.

3. Limitação do escopo: $\mathrm{O}$ conceito da EF não consegue representar toda a gama de problemas ambientais. Um exemplo disso são recursos sem uma capacidade regenerativa significativa, os quais não se encaixam no conceito de produtividade da BC. (SCHAEFER et al., 2006). Tendo em mente que o escopo da pesquisa estava bastante definido, não houve preocupação com essa limitação.

4. Sensibilidade a problemas de qualidade de dados: É necessária alta qualidade para todas as variáveis e dados de entrada. A análise baseia-se no acesso a uma base de dados ambiental confiável aliada a técnicas estatísticas disponíveis, que contêm valores, que exigem algum tipo de técnica de imputação. Dessa forma, a margem de erro dos cálculos de EF e BC com base em lacunas das fontes de dados torna-se de difícil quantificação. (SCHAEFER et al., 2006). 
Considerando que a Global Footprint Network é a única entidade que possui dados robustos a respeito da $\mathrm{EF}$, foi considerado o risco de problemas nos dados, porém viu-se que em grande parte dos trabalhos acadêmicos, esses mesmos dados são utilizados, o que não afeta a credibilidade da pesquisa e de seus resultados.

5. Transparência das suposições e seleções: A construção do indicador composto envolve uma série de etapas em que cabe ao analista realizar julgamentos. Por exemplo, a seleção da variável de entrada (consumo de recursos e geração de resíduos), a escolha de fatores de ponderação e o tratamento de valores faltantes (técnica de imputação). Para esse tipo de situações, é necessária a descrição de um procedimento padrão adotado. (SCHAEFER et al., 2006). Considerando que a pesquisa envolve um modelo em construção e para tal, faz-se necessária a simulação de dados, seguidos por julgamentos, os quais foram validados com especialistas da área.

6. Base científica para os fatores de ponderação: Os cálculos de EF e BC incluem um conjunto de categorias de recursos, para os quais devem ser aplicados fatores de ponderação. Os procedimentos de estimação, por não estarem adequadamente documentados, não permitem a realização de análises independentes. (SCHAEFER et al., 2006). Para essa pesquisa foi realizada uma análise independente, visto que o objeto de pesquisa possui fatores de ponderação pré-determinados.

7. Quantidade ilimitada de planetas: a metodologia considera uma quantidade ilimitada de planetas, ao invés de considerar que assim como há uma quantidade finita de recursos, há somente um único planeta. (BOFF, 2012 p.25; FAO, 2013 p.124; GUTZLER et al., 2015 p.506). Essa limitação foi encarada como uma das motivações da pesquisa, visto que a metodologia apresenta resultados utilizando apenas esse indicador e por isso a pesquisa teve por objetivo apresentar um indicador diferenciado, que propicia uma visão mais realista do uso de recursos naturais na produção e consumo global de carne bovina.

\subsubsection{Adaptação da EF nessa pesquisa}

Uma vez que o objetivo geral dessa pesquisa consistiu na proposição de um modelo prospectivo com cenários globais para identificação de um padrão sustentável de produção e consumo de carne bovina pela população global para 2040, foi analisada a EF de apenas um ecossistema: 
Ef_Grazing ou Pastagem. Os dados da EF utilizada nessa pesquisa foram cedidos pela Global Footprint Network (GLOBAL FOOTPRINT NETWORK, 2016).

A EF de pastagem avalia a demanda por pastagens para alimentar o gado e a demanda incorporada de pastagens em bens comercializados. Os cálculos estimam as necessidades totais de alimento de todos os animais produzidos e a porcentagem de necessidades de energia pecuária derivadas de alimentos concentrados, colheitas forrageiras e resíduos de culturas. A diferença entre a necessidade total de ração e a oferta total de alimento cortado é considerada igual à demanda por pastagens. (LAZARUS et al., 2014).

A seção de pastagem da NFA 2016 baseia-se na metodologia e dados propostos por HABERL et al. (2007) para o cálculo da apropriação humana da produção primária líquida (ou Net Primary Production). O cálculo é iniciado com o número de animais em um país e suas necessidades de alimentação/ração. Essas necessidades de alimentação são parcialmente preenchidas através de alimentos produzidos pelo ecossistema: alimentos cultivados especificamente para serem alimentação animal, resíduos e gramíneas. Uma vez que a procura de alimento satisfeita pelas fontes acima tenha sido contabilizada, a quantidade restante de alimento requerido é assumida como sendo fornecida por meio de pastagem. A estimativa da quantidade de pastagem necessária é baseada na divisão do alimento de relva requerido pelo rendimento médio de pastagens. (LAZARUS et al., 2014).

Para os cálculos são utilizadas fichas técnicas - FT, as quais norteiam o pasto e as seções a serem calculadas na EF. Essas envolvem tanto a terra de pastagem incorporada como a EF da lavoura, uma vez que ambos os tipos de uso da terra contribuem para a alimentação do gado. (LAZARUS et al., 2014). Cada uma das FTs está descrita a seguir.

1. Número estimado de animais: As EFs reportadas por tipo de ração são calculadas multiplicando-se a quantidade total importada pelo valor de intensidade de EF correspondente.

2. Riqueza animal: A função dessa FT é determinar a intensidade da EF de animais e produtos de origem animal exportados pelo país atual em questão.

3. Intensidade estimada de animais: identifica se o bovino é um produto primário ou derivado da manada codificada, seus rendimentos (quantidade em tonelada produzida) e o fator de 
equivalência de solo. A intensidade calcula a EF da unidade de produção (ou o seu impacto) dividindo o fator de equivalência pelo fator de rendimento da unidade de produto bovina.

4. Quantidade de Ração/Alimento: é a soma de todas os alimentos consumidos por cada animal de pastagem, acrescido de erva e de resíduos de colheita em toneladas por peso vivo.

5. Categorias de Ração/Alimento e Intensidade: identifica as diferentes categorias de alimentação por tipo de animal e sua respectiva intensidade ou impacto de cada alimento em hectares globais por tonelada.

7. Ração/Alimento Bovino: enumera a quantidade de alimento calculada e a EF incorporada de cada tipo de uso da terra.

8. Pastagem: enumera a produção primária líquida de pastagens e a superfície de pastagens no país em questão e calcula-se os valores de rendimento do fator de rendimento e da grama.

9. Regiões: cada país é codificado com sua EF correspondente, de acordo com o código FAO do país.

10. Resíduos: essa variável inclui o fator de colheita; a taxa de valorização; a percentagem de resíduos de culturas recuperadas utilizados para alimentação bovina.

11. Demanda: é calculada a ingestão diária de alimento para as espécies identificadas em cada linha, por região e para o mundo como um todo.

Com base nessas fichas técnicas, a metodologia da EF para Ef_Grazing ou Pastagem pela Global Footprint Network é realizada. O cálculo global de Ef_Grazing foi cedido de forma completa em formato xlsx (Microsoft Excel) dividido em AreaPerCap; AreaTotHA; BiocapPerCap; BiocapTotGHA; EFConsPerCap; EFConsTotGHA; EFExportsPerCap; EFExportsTotGHA; EFImportsPerCap; EFImportsTotGHA. Para efeitos dessa pesquisa foram considerados os dados AreaTotHA; BiocapTotGHA; EFConsTotGHA; EFExportsTotGHA; EFImportsTotGHA. 
Uma vez que um dos diferenciais dessa pesquisa é o desenvolvimento de uma metodologia, seguida por um modelo prospectivo, o subtítulo a seguir têm como objetivo analisar diferentes metodologias de cenários prospectivos que poderiam ser aplicáveis a essa pesquisa.

\subsection{Metodologia de Cenários Prospectivos}

No âmbito de Estudos do Futuro, 'cenário’ é um termo utilizado por GODET (1993 p.70) para descrever um conjunto formado por uma descrição de uma situação futura juntamente com a evolução dos eventos, o qual permite passar de uma situação de origem para uma situação futura de forma coerente. SCHWARTZ (2000) define cenário como uma ferramenta para organizar as percepções de uma pessoa sobre ambientes futuros alternativos em que as consequências de uma visão vão acontecer, e ressalta que o principal objetivo deste processo é estabelecer estratégias que sejam compatíveis com todos os futuros possíveis; e, independente de qual futuro aconteça, que se esteja preparado para enfrentá-lo.

Mediante as definições mencionadas, é compreensível que a construção de cenários é uma técnica baseada na percepção individual do futuro. Porém, dentro dessa sucinta afirmativa é necessária a inclusão de um fator importante: o cenário não é somente um ato especulativo, mas também é orientado ao futuro. De acordo com GODET (1993), o futuro não é simples ou único, mas é múltiplo e por isso, é possível a construção de diferentes futuros potenciais. A descrição de um potencial futuro e das progressões necessárias para atingi-lo forma um cenário; e provavelmente por essa razão, é possível derivar uma infinidade de resultados do processo de planejamento por cenários. Para PORTER (1998), cenário é uma visão consistente do que o futuro poderia ser e por meio da construção de múltiplos cenários, é possível extrapolar sistematicamente os possíveis resultados da incerteza para uma opção estratégica.

A metodologia de cenários é uma das alternativas indicadas por diferentes estudiosos (CORNELIUS; VAN DE PUTTE; ROMANI, 2005; GARVIN; LEVESQUE, 2005; SCHOEMAKER, 1995) para se capturar em detalhes possibilidades amplas para o futuro, na tentativa de visualizar oportunidades em um ambiente de incertezas. Previamente à construção de cenários é necessário definir o escopo de análise, os atores envolvidos no processo e as tendências e incertezas associadas ao negócio (SCHOEMAKER, 1995). Como resultado do processo, são criados cenários descrevendo futuros genericamente diferentes, a partir dos quais podem ser formuladas diferentes estratégias. (SCHOEMAKER, 1992). 
Há diferentes metodologias que podem ser aplicadas, de forma combinada ou isolada, para a elaboração de cenários. Há algumas categorias que podem classificar os métodos de construção de cenários: Lógica Intuitiva (Intuitive Logics) abordada por SCHWARTZ (2000), Análise do Impacto Cruzado (Cross-impact Analysis), abordada por MARCIAL (2015), Análise do Impacto de Tendências (Trend-impact Analysis) indicada por HUSS; HONTON (1987) e Elaboração de Cenários desenvolvida por WRIGHT, J. T. C.; SPERS (2006). A seguir, serão explicitadas três das quatro metodologias mencionadas, juntamente com as respectivas etapas de aplicação, por terem possíveis aplicações no modelo dessa pesquisa.

\subsubsection{Lógica Intuitiva}

O método da Lógica Intuitiva tem como principal objetivo abranger a forma de tomada de decisões, por meio da criação de modelos mentais, e é definido por SCHWARTZ (2000) em oito etapas:

1. Identificação da questão principal: segue a premissa de que o desenvolvimento de cenários deve ser iniciado pelo assunto específico e complementado pelo uso de modelos de decisões que definirão as prioridades da questão a ser analisada.

2. Identificação dos fatores-chave no ambiente: esses fatores são forças que apresentam no ambiente próximo e que estão relacionadas de forma estreita com a questão principal identificada na etapa 1 .

3. Forças Motrizes: definição de forças macroambientais não tão óbvias de identificar, mas que assim como os fatores chave podem impactar tanto o desenvolvimento da questão principal do cenário como os fatores-chave.

4. Classificação por importância e incerteza: possui como foco identificar os três fatores ou tendências que tenham o maior nível de importância e de incerteza, levando em consideração os fatores chave e as forças motrizes (definidos nas etapas 2 e 3 ).

5. Seleção das lógicas dos cenários: as variáveis que foram classificadas na etapa 4 devem ser posicionadas nos eixos através do desenvolvimento dos cenários.

6. Descrição dos cenários: ocorre o detalhamento dos cenários, que é a parte fundamental, tendo como foco a lista de fatores-chave e as tendências 
identificadas nas etapas 2 e 3 e em forma de narrativa. Em seguida, devem ser verificadas as implicações de cada cenário.

7. Análise das implicações e opções: consiste no desenvolvimento de ações ou estratégias de adaptabilidade, que promovam a escolha de uma estratégia robusta, com ações que produzirão resultados satisfatórios para o assunto específico elaborado na etapa 1.

8. Seleção de indicadores e sinalizadores principais: concentra-se na seleção de indicadores e sinalizadores para o monitoramento em longo prazo.

\subsubsection{Análise do Impacto de Tendências}

A Análise de Impacto de Tendências enfoca o efeito de determinados eventos nas tendências das variáveis analisadas em um dado período de tempo, conforme explica BONTEMPO (2000). Ao contrário da lógica intuitiva, esse método objetiva capturar as tendências, extrapolá-las e verificar os efeitos de certos eventos relevantes na sua evolução. BONTEMPO (2000) esclarece que essa abordagem conecta métodos tradicionais de previsão como análises de séries de tempo e econometria com fatores qualitativos, compelindo na identificação de eventos que influem sob a variável analisada e na avaliação das probabilidades de sua ocorrência e de seus impactos.

De acordo com BOROUSH; THOMAS (1992), essa metodologia é dividida em três etapas principais:

\section{1- Preparação}

1.1 Definição de escopo: tem como objetivo a definição do limite de processo de cenários, ou seja, delimitar o objetivo do desenvolvimento de cenários.

1.2 Identificação das forças motrizes: consiste em uma análise qualitativa, com o objetivo do detalhamento de incertezas e rupturas do ambiente.

\section{2- Desenvolvimento}

2.1 Construção do conjunto de cenários: essa é a fase em que é realizada uma classificação de forma sistemática, construindo os vários estados alternativos das forças motrizes em forma de matriz e dessa forma possibilita a construção de cenários compreensíveis e lógicos. 
2.2 Escolha dos cenários alternativos a serem detalhados: devem ser selecionados os cenários que possuem maiores desafios, mas também os que propiciam as maiores oportunidades para a organização.

2.3 Preparação de projeções para cada cenário: devem ser relacionadas as tendências e eventos necessários para a ocorrência de cada cenário, projetando-se de forma qualitativa ou quantitativa cada variável no tempo com base nesse conjunto de hipóteses.

3- Apresentação e utilização

3.1 Documentação: por meio de gráficos e narrativas, os cenários devem ser descritos gerando uma documentação adequada para análise, onde serão apresentadas as hipóteses e implicações de cada cenário de forma clara e abrangente.

3.2 Implicações de cada cenário: a documentação deverá apresentar os cenários contrastados, possibilitando uma comparação das implicações de cada cenário.

\subsubsection{Elaboração de Cenários}

Segundo PORTER (1998), cenários são esboços parciais de alguns aspectos do futuro cuja estruturação pode consistir em formas puramente narrativas, ou até modelos detalhados com dados quantitativos. O cenário, como instrumento de apoio à decisão, pode ser encarado não como um exercício de predição, mas uma atividade que pretende fazer descrições plausíveis e consistentes de situações futuras possíveis. (WRIGHT, J. T. C.; SPERS, 2006).

Com base nisso, para WRIGHT, J. T. C.; SPERS (2006), há três possibilidades de visões do futuro: a visão extrapolativa, exploratória e normativa. A visão extrapolativa busca projetar o futuro, a partir do que ocorreu no passado. Na visão exploratória, admite-se que o futuro pode ser diferente do passado, e busca-se prever diferentes cenários daquilo que possa acontecer. Por fim, a visão normativa busca projetar o que a organização deseja que ocorra no futuro. Seria, dessa forma, o melhor cenário possível.

O método de elaboração de cenários elaborado por (WRIGHT, J. T. C.; SPERS, 2006) consiste em oito etapas:

1. Definição de escopo e objetivos dos cenários.

2. Identificação das variáveis, tendências e eventos fundamentais.

3. Estruturação das variáveis dos cenários, identificando as tendências pesadas e fatores invariantes, eventos incertos e fatos portadores do futuro. Também é necessário 
identificar as relações de causa e efeito entre as variáveis, identificando variáveis causais, intermediárias e resultantes.

4. Projeção dos estados futuros das variáveis, que são projeções quantitativas e qualitativas de 2 a 4 estados futuros por variável. As técnicas usualmente utilizadas nessa etapa são a extrapolação de tendências quantitativas e a técnica Delphi.

5. Identificação de temas motrizes dos cenários, classificados como: (1) tendencial, mais provável; (2) exploratório: considera o desenvolvimento de temas ou eventos direcionadores do ambiente. (3) normativo ou desejado.

6. Montagem de uma matriz morfológica de cenários, com uma análise de consistência de temas direcionadores, invariantes e com eventos incertos contendo estados futuros das variáveis causais, intermediárias e, por fim, das resultantes.

7. Redação e validação dos cenários. Essa etapa requer o detalhamento dos cenários, com a descrição da evolução dos mesmos e a explicitação das relações e sequências de causa e efeito entre as variáveis consideradas.

8. Elaboração dos cenários de transição ou de planejamento.

Com base nas 3 metodologias abordadas, a selecionada para aplicação nessa pesquisa foi a Elaboração de Cenários, desenvolvida por WRIGHT, J. T. C.; SPERS (2006). Ela foi selecionada, em virtude, especialmente, de suas vantagens, que podem ser descritas como a (1) utilidade de combinadas técnicas quantitativas e qualitativas; (2) avaliação de probabilidades de ocorrência de eventos futuros por meio da identificação de forças motrizes e (3) a possibilidade de identificação de problemas que poderiam ser ignorados ou deixados de lado por métodos menos abrangentes. (WRIGHT, J. T. C.; SPERS, 2006).

Como desfecho para o delineamento e aprofundamento na questão central dessa pesquisa, o próximo capítulo tem como intuito abordar os constructos definidos na pesquisa.

\subsection{Constructos de Análise da Pesquisa}

Considerando os objetivos da pesquisa e os elementos apresentados no referencial teórico, esse capítulo destinou-se a explanação dos principais elementos integrantes do constructo de análise que subsidiou a proposição de um modelo prospectivo que contemple cenários globais e identifique um padrão sustentável de produção e consumo de carne bovina, através da 
combinação do uso de recursos naturais, variáveis econômicas, tendências tecnológicas e padrões globais de consumo de alimentos.

A Figura 3 representa o modelo de constructos adotado para esta pesquisa, incorporando os elementos que delimitam seu escopo em cinco grupos:

Figura 3: Constructos da Pesquisa

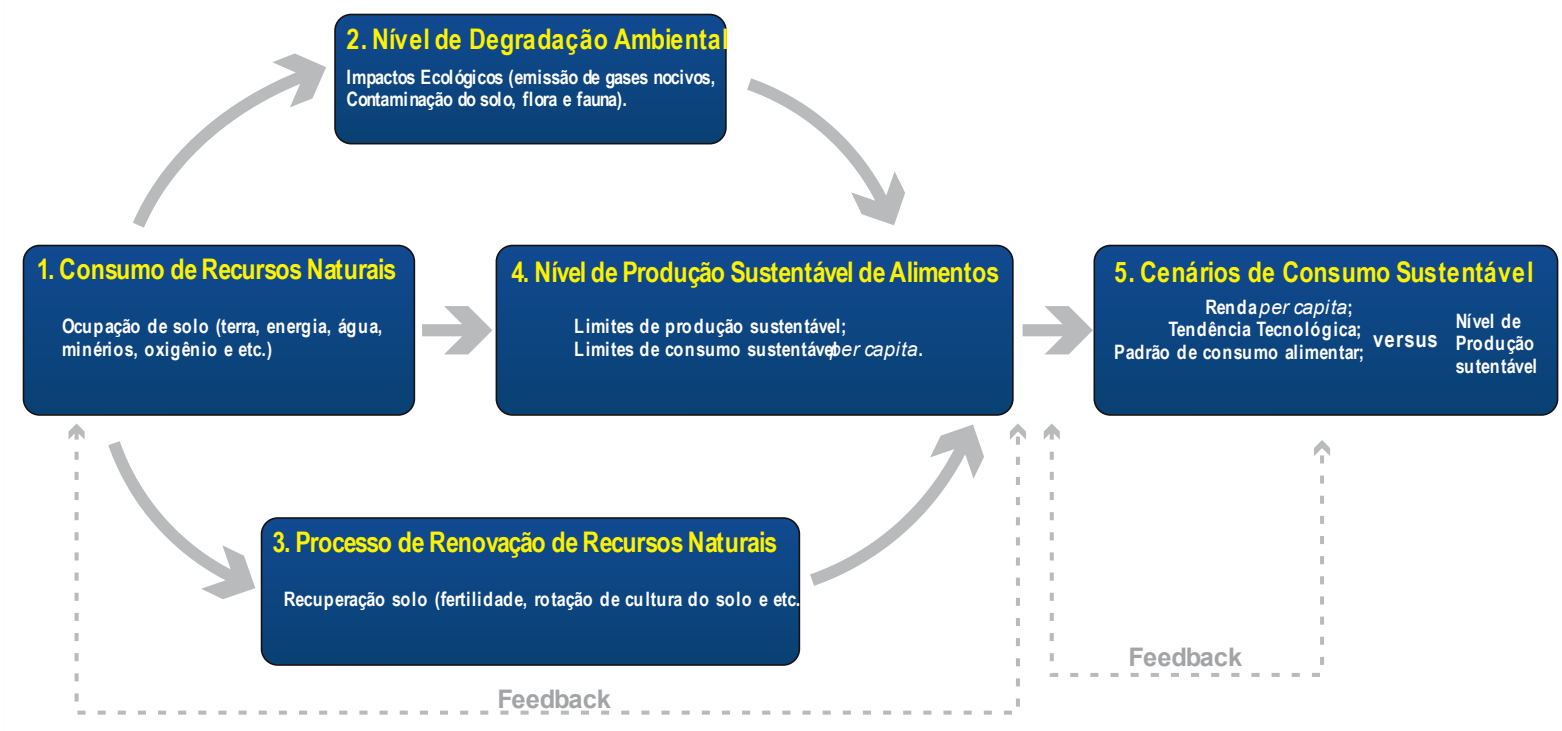

Fonte: desenvolvido pela autora

1. Consumo de Recursos Naturais - nesse quadrante foram caraterizados os recursos fundamentais e associados à evolução da produção de carne bovina: ocupação de solo, energia, água, minérios e oxigênio (explicitados no capítulo 2 dessa pesquisa e considerados na metodologia Ecological Footprint).

2. Nivel de Degradação Ambiental - nesse quadrante foram identificadas implicações ambientais na produção de carne bovina: emissão de substâncias e gases nocivos, contaminação do solo, flora e fauna (explicitados no capítulo 2 dessa pesquisa).

3. Processo de Renovação de Recursos Naturais - com base nas implicações identificadas no quadrante anterior, foram identificadas formas de mitigar e renovar os recursos naturais utilizados na produção de carne bovina: recuperação de biomassas degradadas, fertilidade do solo, rotação de cultura do solo e reaproveitamento/captação de recursos hídricos. (explicitados no capítulo 2 dessa pesquisa e considerados parcialmente na Biocapacidade da metodologia Ecological Footprint). 
4. Nível de Produção Sustentável - com base na análise dos três quadrantes anteriores, esse nível do modelo destina-se a identificar um limite de produção sustentável associado ao consumo per capita sustentável de carne bovina. Esse é um dos objetivos da metodologia Ecological Footprint - ser um indicador de sustentabilidade, porém ela é aplicada de forma geral e dessa forma a pesquisa destina-se a realizar uma aplicação de forma direta na produção pecuária bovina de corte.

5. Cenários de Consumo Sustentável - como parte final do modelo e com base nas implicações de produção e consumo de carne bovina, são analisados indicadores sociais (população), econômicos (renda per capita e padrão de consumo), e de sustentabilidade (biocapacidade) juntamente com índices de desenvolvimento tecnológico associado à produtividade agropecuária (eficiência no uso de recursos) versus níveis sustentáveis de produção pecuária bovina de corte projetados para 2040.

Lembrando que em virtude de o Brasil estar presente tanto no ranking dos maiores criadores bovinos como no dos maiores produtores de carne bovina, ele foi considerado uma referência para a análise nesse estudo, nos quesitos de produção e produtividade pecuária.

Á seguir, foi considerado o escopo metodológico aplicado nessa pesquisa, dividido por etapas e procedimentos aplicados.

\subsection{Escopo e Procedimentos Metodológicos}

Esse subtítulo tem como objetivo apresentar o escopo metodológico aplicado nessa pesquisa, discutindo e descrevendo os principais métodos e procedimentos que foram utilizados para a sua efetiva execução.

\subsubsection{Método de Pesquisa}

A escolha do instrumental metodológico pode parecer, a um leigo no assunto, ou mesmo a um pesquisador inexperiente, uma mera formalidade que todo autor deve cumprir, sob pena de que os textos científicos sejam considerados incompletos ou deficientes. $\mathrm{O}$ fato é que a descrição inadequada do escopo metodológico realmente compromete a qualidade da pesquisa, já que não 
permite ao leitor compreender a essência do que o pesquisador pretendia quando da elaboração de seu trabalho, muito menos se aquilo que obteve realmente está de acordo com os objetivos preestabelecidos. Desta forma, não se trata apenas da demonstração do conjunto de técnicas que o autor domina ou mantém maior proximidade ideológica, mas das condições às quais a própria pesquisa está subordinada.

De acordo com DUBÉ; PARÉ (2003), o rigor metodológico, por si só, não é um elemento suficiente para garantir a qualidade da pesquisa, mas há também a necessidade de se cumprirem requisitos mínimos para que seja desenvolvida uma pesquisa com qualidade e alto grau de relevância para a comunidade científica e para a sociedade como um todo. Neste sentido, MARCONI; LAKATOS (2010) apresentam condições fundamentais na escolha do instrumental metodológico, entre essas o tipo de pesquisa, que dependerá de vários fatores relacionados com a pesquisa, ou seja, a natureza dos fenômenos, o objeto da pesquisa [...] e outros elementos que possam surgir no campo da investigação.

Especificamente neste trabalho, dentre os fatores até então apresentados pela autora, merece consideração preliminar o contexto da pesquisa, que diz respeito não só à natureza dos fenômenos então observáveis, como também os resultados decorrentes desses fenômenos, especialmente em relação ao meio ambiente e seus recursos naturais. Neste sentido, em se tratando o objeto de análise (modelo prospectivo de produção e consumo sustentável de carne bovina) de um fenômeno contemporâneo do qual ainda não existem elementos teóricos que os fundamentem, emerge a necessidade do uso de uma abordagem qualitativa, exploratória, focada na sua descrição e que resulte na consolidação de seus fundamentos teóricos.

Considerando-se esses aspectos, a primeira fase dessa pesquisa foi classificada como qualitativa, de natureza exploratória, a qual segundo HAIR JR et al. $(2005$ p.83,86) é empregada para desenvolver uma melhor compreensão do assunto analisado ou quando as questões formuladas pelo pesquisador acerca do tema de pesquisa são vagas, há pouca teoria disponível para orientar as previsões, e podem mapear tendências e dar origem a hipóteses.

Como parte da primeira fase da pesquisa, foi desenvolvida uma pesquisa RBS. A RBS é uma ferramenta aplicada para mapear trabalhos publicados concernentes ao tema específico de pesquisa, a fim de que o pesquisador seja capaz de elaborar uma síntese do conhecimento existente sobre o assunto. (BIOLCHINI et al., 2007 p.135) Para efeitos de comparação com o 
conjunto de artigos presentes em cada base, foi realizada a RBS, de caráter narrativo e baseada em métodos, que tem por objetivo alcançar maior qualidade nas buscas e resultados da revisão bibliográfica, ou seja, obter a compreensão do "estado da arte" da utilização do modelo Ecological Footprint Analysis, por meio da compilação de dados, refinamento de hipóteses, estimação de amostras, definição ampliada do método de pesquisa a ser adotado para o problema e por fim definir a direção da pesquisa visando melhores resultados. (COOK; MULROW; HAYNES, 1997 p.3-4) Para isso foi necessário adotar um procedimento, um conjunto de passos, técnicas e ferramentas específicas. A definição para a RBS adotada neste trabalho é uma adaptação da proposta de LEVY; ELLIS (2006 p. 182-183), a qual foi realizada em três bases de dados de trabalhos acadêmicos científicos, com o filtro de trabalhos acadêmicos publicados nos últimos 10 anos (2004-2014) com o string de busca Ecological Footprint Analysis.

A pesquisa foi desenvolvida em 37 horas e obteve, após os filtros 1 e 2, a soma de 153 artigos publicados em periódicos internacionais e retorno médio de $28 \%$, conforme demonstrada pela tabela 1, seguida pela distribuição das publicações por base e ano na tabela 2.

Tabela 1: Revisão Sistemática Ecological Footprint

\begin{tabular}{|c|c|c|c|c|c|c|c|}
\hline $\begin{array}{c}\text { Registro das buscas na base } \\
\text { de dados e periódicos: String } \\
\begin{array}{c}\text { - Ecological Footprint } \\
\text { Analysis }\end{array}\end{array}$ & $\begin{array}{c}\text { F. } \\
\text { Preliminar }\end{array}$ & F1 & T1 & F2 & T2 & Exclui. & Rep. \\
\cline { 2 - 9 } & 2217 & 165 & $10: 00$ & 153 & $27: 00$ & 12 & 153 \\
\hline
\end{tabular}

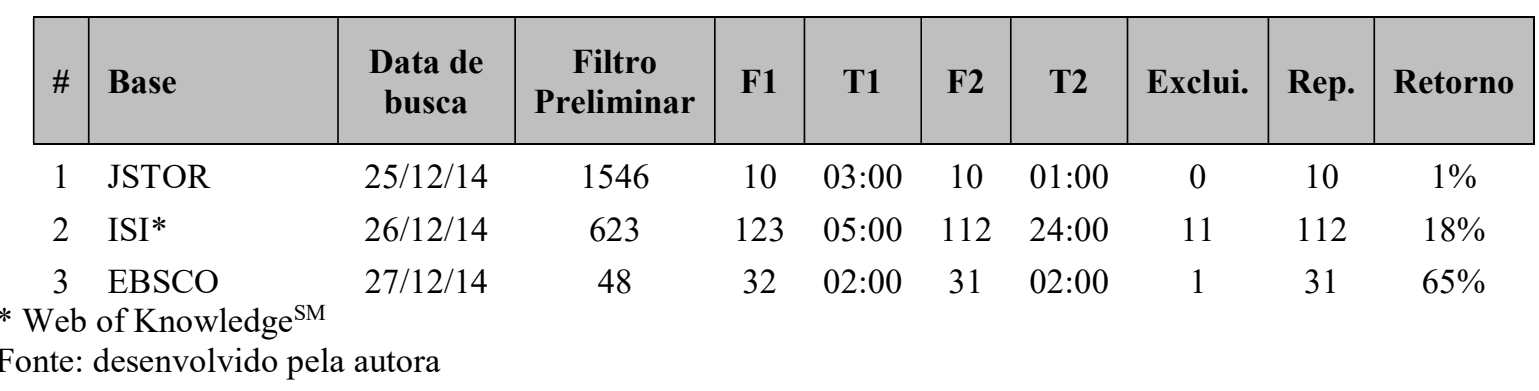

Tabela 2: Distribuição das publicações por base e ano

\begin{tabular}{cccc} 
Ano & JSTOR & ISI* & EBSCO \\
\cline { 2 - 4 } 2004 & 1 & 3 & - \\
\hline 2005 & 1 & 1 & 2 \\
\hline 2006 & 1 & 6 & 3 \\
\hline
\end{tabular}




\begin{tabular}{cccc}
\hline 2007 & 3 & 12 & 5 \\
\hline 2008 & 3 & 15 & 3 \\
\hline 2009 & - & 13 & 5 \\
\hline 2010 & - & 8 & 3 \\
\hline 2011 & - & 9 & 2 \\
\hline 2012 & - & 18 & 2 \\
\hline 2013 & 1 & 13 & 3 \\
\hline 2014 & - & 14 & 3 \\
\hline \multicolumn{4}{r}{ Fonte: desenvolvido pela autora }
\end{tabular}

Os dados apresentados nas tabelas mencionadas mostram que a produção científica relacionada ao tema é relativamente nova, visto que o artigo principal do indicador Ecological Footprint é da década de 90 (REES, W. E., 1992) e por isso há margem para a construção de novos estudos e de aprimoramentos no modelo.

A segunda parte deste levantamento buscou analisar os estudos que foram realizados nas publicações identificadas nos últimos dez anos nas três bases analisadas.

A tabela 3 apresenta dados que possibilitam o entendimento de que $56 \%$ dos trabalhos publicados no tema da EF são casos de estudos de regiões, normalmente aplicados ao urbanismo; 22\% a agropecuária ou meio ambiente, com aplicações a energia, água ou combustíveis fosseis; $12 \%$ a indústrias de madeira, frutas ou universidades com o intuito de mensurar a EF e utilizá-lo como forma de ensino de sustentabilidade e 10\% são notas ou comentários que fazem alusão a uma pesquisa realizada concernente ao indicador ou alguma nota de correção. Um fato interessante é que os trabalhos identificados não apresentam aplicações da EF com uma visão global e cenários prospectivos - isso demonstra que um estudo com essas características apresenta ineditismo na academia.

Tabela 3: Distribuição das publicações por ano, base e caso de estudo da EF

\begin{tabular}{|c|c|c|c|c|c|c|c|c|c|c|c|c|}
\hline \multirow{2}{*}{ Ano } & \multicolumn{4}{|c|}{ JSTOR } & \multicolumn{4}{|c|}{ ISI* } & \multicolumn{4}{|c|}{ EBSCO } \\
\hline & CEP & AGRO & ORG & COM & CEP & AGRO & ORG & $\mathrm{COM}$ & CEP & AGRO & ORG & $\mathrm{COM}$ \\
\hline 2004 & 1 & - & - & - & 2 & - & - & 1 & - & - & - & - \\
\hline 2005 & - & - & - & 1 & 1 & - & - & - & 1 & 1 & - & - \\
\hline 2006 & - & 1 & - & - & 3 & 1 & 1 & 1 & 1 & 1 & 1 & - \\
\hline 2007 & 3 & - & - & - & 7 & 3 & 1 & 1 & 1 & 2 & - & 2 \\
\hline 2008 & 1 & - & - & 2 & 9 & 4 & 2 & - & 2 & 1 & - & - \\
\hline
\end{tabular}




\begin{tabular}{|l|cccc|cccc|cccc|}
2009 & - & - & - & - & 8 & 2 & 1 & 2 & 3 & 1 & 1 & - \\
\hline 2010 & - & - & - & - & 6 & 2 & - & - & 2 & 1 & - & - \\
\hline 2011 & - & - & - & - & 6 & 2 & 1 & - & 1 & 1 & - & - \\
\hline 2012 & - & - & - & - & 9 & 1 & 7 & 1 & - & 1 & 1 & - \\
\hline 2013 & - & - & - & 1 & 6 & 4 & 2 & - & 1 & 3 & - & - \\
\hline 2014 & - & - & - & - & 9 & 1 & 1 & 3 & 2 & - & - & 1 \\
\hline
\end{tabular}

* Web of Knowledge ${ }^{\mathrm{SM}}$

Nota: CEP (Cidade, Estado, País); AGRO (agropecuária, meio ambiente); ORG (empresas, indústrias, universidades e etc); COM (comentários ou correções à artigos publicados)

Fonte: desenvolvido pela autora.

A tabela 4 apresenta uma distribuição da metodologia empregada nos trabalhos analisados. Em suma, $48 \%$ se baseiam unicamente na aplicação da EF; $18 \%$ aplicaram a EF com técnicas estatísticas como Monte Carlo, Partial Least Square - PLS ou métodos econométricos variados; $20 \%$ análises comparativas do EF e indicadores de sustentabilidade e apenas 14\% apresentaram sugestões de melhoria na metodologia aplicada na pesquisa.

Ao todo, conforme apresentado na Tabela 1, 153 artigos receberam análise nos campos de Título, Resumo e Palavras-Chave (filtro 1) e Introdução e Conclusão (filtro 2). Dentre os artigos analisados, apenas dois (AGOSTINHO; PEREIRA, 2013; ALVARENGA; DA SILVA JÚNIOR; SOARES, 2012) foram publicados por pesquisadores brasileiros.

Tabela 4: Distribuição das publicações por ano e metodologia aplicada da EF

\begin{tabular}{ccccc}
\hline Ano & $\begin{array}{c}\text { Aplicação } \\
\text { Tradicional }\end{array}$ & $\begin{array}{c}\text { Aplicação de } \\
\text { Métodos } \\
\text { Estatísticos }\end{array}$ & $\begin{array}{c}\text { Comparações } \\
\text { com } \\
\text { Indicadores }\end{array}$ & $\begin{array}{c}\text { Aplicação } \\
\text { Tradicional } \\
\text { +Sugestões } \\
\text { de Ajustes }\end{array}$ \\
\hline 2004 & 3 & & 1 & \\
\hline 2005 & 3 & & & 1 \\
\hline 2006 & 3 & 2 & 2 & 3 \\
\hline 2007 & 9 & 6 & 3 & 2 \\
\hline 2008 & 10 & 3 & 4 & 4 \\
\hline 2009 & 9 & 3 & 4 & 2 \\
\hline 2010 & 5 & 3 & 1 & 2 \\
\hline 2011 & 6 & 2 & 3 & \\
\hline 2012 & 11 & 2 & 5 & 2 \\
\hline 2013 & 9 & 5 & 2 & 1 \\
\hline 2014 & 6 & 1 & 5 & 5 \\
\hline
\end{tabular}


Durante a RBS desenvolvida com base no assunto Ecological Footprint Analysis, foram identificadas algumas pesquisas baseadas em produção de alimentos de forma individual, mas nenhuma com proposta similar a essa pesquisa. Dessa forma identificou-se um campo a ser analisado a fim de produzir contribuições acadêmicas e sociais.

Em continuidade a primeira fase de pesquisa foi realizada uma pesquisa exploratória, por meio de um levantamento de informações em dados secundários, com base em recursos naturais juntamente com as consequências advindas da pecuária bovina de corte, com o objetivo de identificar os benefícios e malefícios ambientais. Nessa fase foram buscados indicadores de sustentabilidade que ajudassem a responder a pergunta de pesquisa proposta na pesquisa.

$\mathrm{Na}$ segunda fase, essa pesquisa é classificada como qualitativa e quantitativa, de natureza descritiva, a qual segundo GIL (2010), tem como objetivo primordial a descrição das características de determinada população ou fenômeno ou o estabelecimento entre variáveis e pode ir além da simples identificação e determinar a natureza da relação e portanto se aproximar das pesquisas explicativas. MILES; HUBERMAN; SALDANA (2013) destacam três principais características de dados qualitativos coletados de forma correta: (1) são estritamente relacionados a uma situação específica estudada, (2) possuem um grande potencial de fornecem descrições densas que estão sobre o objeto de estudo e (3) são úteis para validar dados quantitativos recolhidos a partir do mesmo objeto. Nessa fase, foram pesquisadas as fases da produção pecuária bovina de corte e identificados dados que demonstram a produção, consumo e a EF atual da pecuária bovina de corte no mundo. Como já mencionado no capítulo 6, para essa pesquisa foi utilizada a metodologia EF como base, seguidas as devidas adaptações relatadas.

Segundo EISENHARDT (1989), o desenvolvimento de modelos e/ou teorias é a atividade central de pesquisadores e tradicionalmente, muitos autores têm desenvolvido modelos e/ou teorias pela combinação de observações da literatura, senso comum e experiência, porém isso em muitas situações conduz à distorções tênues da realidade empírica dos objetos pesquisados. Na terceira fase dessa pesquisa, foi aplicado o método de MILES et al. (2013), o qual codifica procedimentos para análise de dados qualitativos, quantitativos e o desenvolvimento de teorias, com o objetivo de desenvolver o modelo prospectivo de nível sustentável de produção e consumo pecuarista bovino. Os procedimentos utilizados como base consistiram nas fases 1 e 2, ou seja, iniciado pelo levantamento qualitativo de informações secundárias sobre a temática 
de recursos naturais e sua aplicação na pecuária bovina de corte. Á partir disso, foi possível compreender as implicações da pecuária no meio ambiente e deu-se origem ao modelo da pesquisa que analisa as consequências ambientais e as diferentes variáveis que implicam direta ou indiretamente na produção e no consumo da pecuária bovina de corte.

A quarta fase dessa pesquisa objetivava a experimentação do modelo prospectivo desenvolvido na terceira fase e a projeção de cenários futuros. BRUYNE; HERMAN; SCHOUTHEETE (1982) classifica quatro modos de investigação: estudos de caso, comparação, experimentação e simulação. Para essa quarta fase foi selecionada a técnica de simulação como experimento do modelo desenvolvido. Para BRUYNE et al. (1982) e KLEIBOER (1997), simulação é compreendida como a construção e manipulação de um modelo, que pode representar ou refletir as características centrais de um sistema, processo ou ambiente, real ou proposto, sem necessariamente o uso de um computador, pois é possível fazer uma simulação apenas por conjecturas tais como "e se", que podem ser mais abertas e se aproximar de técnicas preditivas de cenários.

BRUYNE et al. (1982) salienta que a simulação é recomendada quando o pesquisador dispõe de dados empíricos e busca um modelo, utilizando a literatura teórica como ponto de partida e faz uso da simulação para realizar sucessivos testes a fim de identificar um modelo funcionalista do objeto estudado e para isso, utiliza o princípio da parcimônia (partindo do mais simples para o mais complexo) e baseando-se em teorias e/ou modelos existentes, visando criar um modelo que tenha solidez tanto do ponto de vista matemático-computacional quanto teórico. Dessa forma, com base na terceira fase, foram realizadas projeções e simulações nos dados coletados e analisados.

Após a validação do modelo, o objetivo é fazer uma previsão sobre acontecimentos futuros, baseando-se em dados do presente. Segundo VICENTE (2005), esse é o principal motivo para que se desenvolvam simulações de projeção, com a finalidade de criar cenários hipotéticos nos quais são compreendidas dinâmicas de mudanças e entendimento de processos. Como continuação da quarta fase, são desenvolvidos cenários prospectivos que irão nortear ações que podem ser realizadas visando benefícios atuais e futuros da produção e consumo de carne bovina. Várias são as metodologias que podem ser utilizadas, de forma combinada ou isolada, para a elaboração de cenários, explicitadas no capítulo 7. Nessa pesquisa, foram elaborados os cenários mediante a aplicação da metodologia desenvolvida por WRIGHT, J. T. C.; SPERS 
(2006), em que são descritas três possibilidades de visões do futuro: a visão extrapolativa, exploratória e normativa.

\subsubsection{Procedimentos}

As fases que constituíram essa pesquisa, juntamente com seus procedimentos estão descritas detalhadamente nas subseções seguintes.

\subsubsection{Primeira Fase}

Uma vez que a pesquisadora não possui conhecimentos aprofundados sobre o tema Recursos Naturais, essa fase baseou-se no levantamento de informações acerca do tema, juntamente com as consequências ambientais da produção e consumo bovino. Além disso, foram analisados indicadores de sustentabilidade para produção e consumo mundial e dentre os investigados, passou-se a considerar como preponderante para responder a pergunta de pesquisa definida inicialmente a metodologia EF. Para isso foram utilizadas fontes renomadas no assunto, tanto nacionais como a Empresa Brasileira de Pesquisa Agropecuária - Embrapa como internacionais a FAO, Global Footprint Network, entre outras.

\subsubsection{Segunda Fase}

Essa segunda fase foi composta de análises das fases que compõe a pecuária bovina de corte (fases de criação, tipos de alimentação, solo apropriado e etc.). Além disso, foram verificados dados quantitativos de produção e consumo mundial.

Inicialmente foi aplicado o Princípio de Pareto (SANDERS, 1987), que é também conhecido como a "regra dos $80-20 "$, por meio do qual foram determinados os países que representam $80 \%$ da produção mundial de carne bovina (Estados Unidos, China, Brasil, Argentina, Rússia, México, França, Índia, Itália, Reino Unido, Alemanha, Austrália, Canadá, Japão, África do Sul, Colômbia, Espanha, Paquistão, Coréia, Egito, Uzbequistão, Venezuela, Ucrânia, Indonésia e Vietnã) e $80 \%$ do consumo mundial de carne bovina (Estados Unidos, China, Brasil, Argentina, Austrália, México, Rússia, França, Alemanha, Canadá, Itália, Índia, Reino Unido, África do Sul, Colômbia, Paquistão, Uzbequistão, Ucrânia, Nova Zelândia, Espanha, Irlanda, Japão, Venezuela e Uruguai) em séries históricas de 1980 a 2011. A partir disso, esses países se tornam foco da pesquisa. Os dados utilizados foram coletados na FAO (2014a). 
Em seguida, foram identificados níveis de produção de carne bovina (em tonelada), produção por cabeça (por arroba), de cada um desses países em mesmas séries históricas (1980 á 2011). Os dados utilizados foram coletados na FAO (2014a).

Como variáveis sociais, foram identificados dados de consumo (em tonelada), consumo (gramas/pessoa/dia), tamanho da população e Pib per capita de cada um desses países em mesmas séries históricas (1980 á 2011). Os dados utilizados foram coletados na FAO (2014a); WORLD BANK (2014e;2014h).

Ademais, aplicando a metodologia EF como base inicial do modelo (explicitada no capítulo 6), foi definida como mais apropriada ao estudo a análise/inclusão da EF de apenas um ecossistema: Ef_Grazing ou Pastagem. Esses dados em mesmas séries históricas (1980 a 2011) da EF utilizada nessa pesquisa foram obtidos por meio da Global Footprint Network (GLOBAL FOOTPRINT NETWORK, 2016), na qual são contemplados dados EF de área, biocapacidade, produção, consumo, importação e exportação convertidos em Global Hectare - Gha.

\subsubsection{Terceira Fase}

A terceira fase é iniciada pelo uso da estatística para investigar questões. A questão investigada é o consumo de carne bovina, por meio da análise de relações entre duas variáveis (Consumo e PIB per capita) em cada um dos países em mesmas séries históricas (1980 á 2011). Segundo HAIR JR et al. (2005), quando há uma ligação coerente e sistemática entre variáveis, pode-se dizer que há uma relação e essa relação pode ser avaliada por meio de técnicas associativas como a correlação e a regressão múltipla. Para todos os países foi realizada a técnica associativa de regressão, lembrando que a relação buscada não é necessariamente causal, mas a presença dela entre as variáveis e prováveis linhas de tendência. (HAIR JR et al., 2005 p.310).

Depois de realizada a análise de associação (regressão múltipla), foi desenvolvida uma tendência global de consumo bovino em função da renda per capita, baseado em dados de consumo de 2011. Ao mesmo tempo, foram utilizadas as equações das regressões múltiplas de cada país para projetar sua demanda per capita futura, com a ressalva de que caso o demanda projetada per capita para 2040 fosse menor do que o atual consumo per capita (2011), fosse mantido o atual consumo para a demanda projetada per capita. Com base nesse cálculo, foi projetada a demanda total por país para 2040. 
Para os índices de população e Pib per capita projetados, foram utilizados dados de estudos desenvolvidos por COOPERS (2015) para 2050.

O dado de biocapacidade utilizado nas simulações foi obtido por meio da Global Footprint Network (GLOBAL FOOTPRINT NETWORK, 2016) e foi mantido em todas as simulações realizadas.

\subsubsection{Quarta Fase}

Com base nos dados levantados e projetados, foram realizadas algumas simulações para o ano de 2040, com o objetivo especial de identificar um cenário sustentável, ou seja, reserva ou equalização de biocapacidade.

A primeira simulação baseou-se no atual cenário global de produção e consumo de carne bovina, juntamente com os impactos decorrentes.

A segunda simulação seguiu a premissa de projetar os dados de população, Pib per capita, demanda per capita e demanda total para 2040, fazendo uso da eficiência do uso de recursos naturais utilizada em 2011 e seus impactos decorrentes.

A terceira simulação tem como objetivo identificar níveis de consumo e produção de carne bovina sustentáveis ou adequados ambientalmente para 2040.

A quarta simulação tem como premissa a aplicação de um nível de eficiência moderado para redução dos impactos decorrentes da produção e consumo global de carne bovina.

Após realizar as simulações, foram elaborados cenários globais prospectivos para produção e consumo de carne bovina.

De acordo com a metodologia de elaboração de cenários selecionada para essa pesquisa, uma das etapas consiste na validação por especialistas dos cenários desenvolvidos. Essa validação foi realizada através de entrevistas, conduzidas por meio de questionário estruturado. A seleção dos especialistas entrevistados se deu através de busca de currículos na Plataforma Lattes (http://lattes.cnpq.br/) pelo termo chave de produção "pecuária bovina de corte", com 
pesquisadores doutores de nacionalidade brasileira. Foi utilizada uma técnica de amostragem não probabilística, que procura obter uma amostra de respondentes conveniente.

A entrevista foi realizada de forma online, por meio de um questionário estruturado, no qual eram abordadas questões centrais concernentes a produção e o consumo de carne bovina no Brasil e no Mundo.

As questões e tópicos abordados na pesquisa estão delineados a seguir.

1- Quais são as principais dificuldades da produção bovina de corte no Brasil e no Mundo?

2- Quais são os diferenciais da produção bovina de corte brasileira, comparada a outros grandes produtores como EUA, China e Argentina?

3- Quais tecnologias estão sendo empregadas atualmente para a melhoria da eficiência produtiva?

4- Quando se fala de sustentabilidade, em quais aspectos ela é aplicada de forma prática na pecuária bovina de corte?

5 - Quando se analisa o consumo de carne bovina no mundo, qual é a tendência vislumbrada por especialistas e quais variáveis implicam nisso?

6-Após a apresentação dos 4 cenários apresentados, indique o cenário que considera (1) extrapolativo (que excede os limites), (2) exploratório (que necessita fundamentos aprofundados) e (3) normativo (que tem capacidade de ser concretizado).

\subsubsection{Limitações do método e procedimentos}

O método de análise desenvolvido para essa pesquisa é de natureza exploratória, adequado, portanto à investigação em profundidade dos temas abordados, porém, está sujeito a determinadas limitações.

Inicialmente há prevista uma subjetividade presente em qualquer investigação no campo das ciências sociais, que se soma às limitações decorrentes da estratégia de investigação escolhida: o desenvolvimento de modelos e/ou teorias. Embora o atual modelo desenvolvido para essa pesquisa tenha ponto de início em um modelo conceituado, foram realizadas adaptações, as quais não passaram por testes reais e efetivos em campo. 
Apesar de ter sido possível constatar, por exemplo, que há um alinhamento de modo geral entre teorias analisadas e especialistas a respeito das percepções de produção e consumo de carne bovina, foi possível constatar também algumas limitações dessa pesquisa. São elas:

- Processamento manual de dados: pode ocasionar em erros de input pela pesquisadora.

- Aplicação de dados provenientes da Global Ecological Network, os quais são apenas imputados no modelo, sem sofrerem análise pormenorizada para a construção do mesmo.

- Número de especialistas entrevistados para validação dos cenários futuros: foram convidados 150 pesquisadores/especialistas brasileiros. No entanto, somente 3 pesquisadores participaram efetivamente da pesquisa. Não foram selecionados pesquisadores estrangeiros pelo curto prazo de execução das entrevistas.

- Processo de entrevista e detalhamento de informações: em vista do período de coleta da pesquisa ter ocorrido em período de recesso e/ou férias em universidades e institutos de pesquisa, em alguns casos, os entrevistados não puderam dedicar muito tempo à entrevista, ou preferiram não ser entrevistados pessoalmente, solicitando, assim, que o roteiro de entrevista fosse enviado por e-mail, ou que a entrevista fosse realizada por skype. Nota-se que, em alguns casos, isso prejudicou a riqueza de informações das entrevistas.

- Vieses da pesquisadora e dos entrevistados: pode ter havido a interferência de vieses pessoais da pesquisadora e dos entrevistados durante a coleta e análises dos dados. Apesar dos cuidados metodológicos descritos, visando à objetividade e imparcialidade na coleta de dados, a realização de entrevistas em profundidade tende a deixar a pesquisa sujeita a tal tipo de viés. 


\section{REVISÃO TEÓRICA}

\subsection{Recursos Naturais}

O ser humano pode ser considerado um inquilino da Terra, que depende da disponibilidade de terra, energia, água e ar no planeta para sua sobrevivência. Ultrapassar os limites existentes desses itens significa caminhar para o suicídio e o ecocídio. A situação atual apresenta, após 200 anos de desenvolvimento econômico, ganhos significativos, propiciados pela Revolução Industrial, de redução das taxas de mortalidade e o crescimento da expectativa de vida (conforme figura 4). Atualmente, em média, as pessoas vivem mais e melhor. (WHO, 2014; WORLD BANK, 2014f).

Figura 4: Relatório Mundial de Anos de Expectativa de Vida adquiridos (1990-2012)

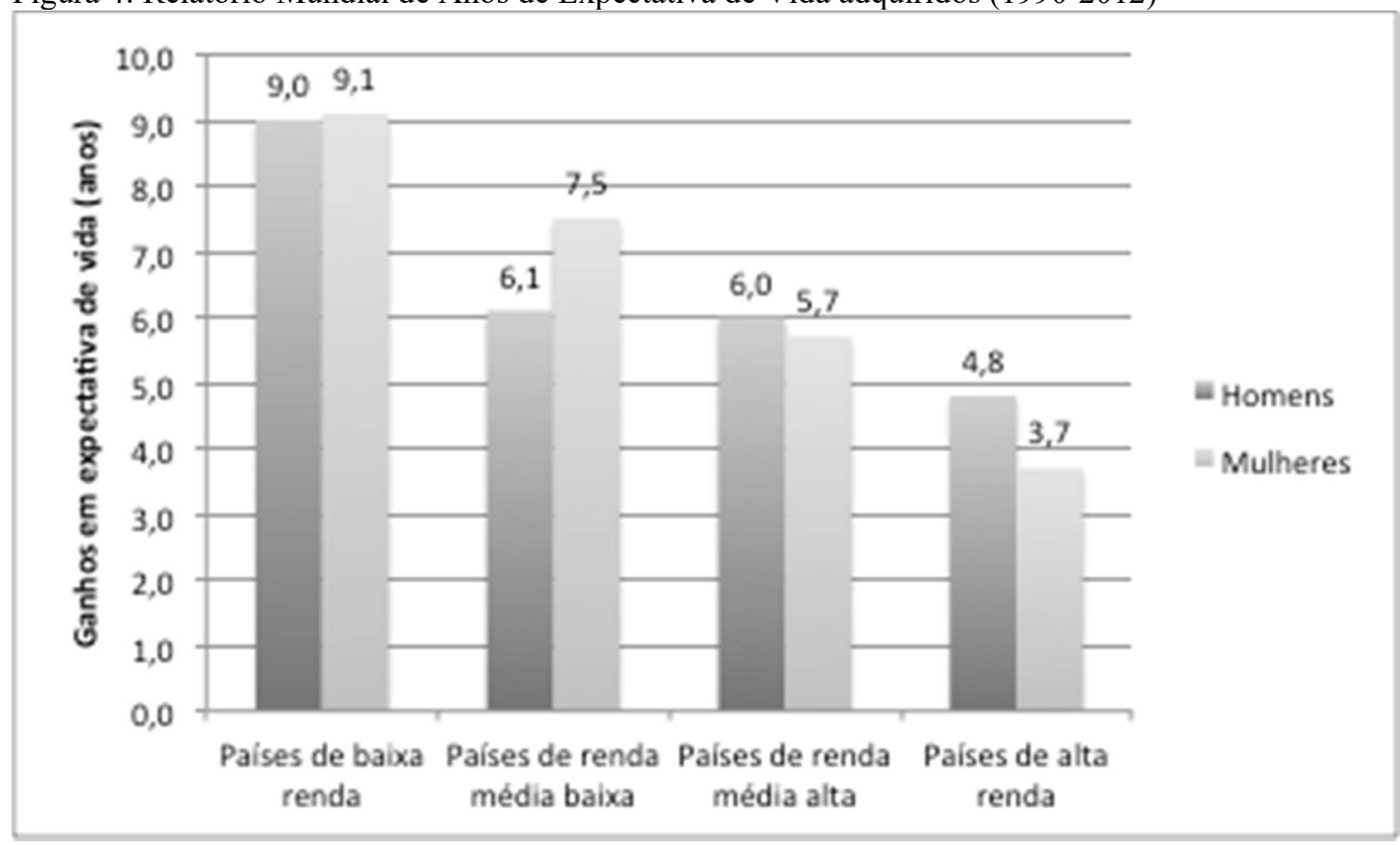

Fonte: (WHO, 2014)

Em contrapartida, o consumo médio da humanidade aumentou. Entre 1800 e 2010 a população mundial cresceu, aproximadamente, sete vezes (de 1 bilhão para 7 bilhões de habitantes) (WORLD BANK, 2014h) e a economia (PIB) aumentou cerca de 50 vezes (WORLD BANK, 2014e). Mas o crescimento da riqueza se deu à custa da pauperização do planeta, ou seja, uso excessivo de recursos naturais, especialmente os não renováveis. (WTO, 2010)

Os recursos naturais - terras, água e material genético - são essenciais para a produção de alimentos, o desenvolvimento rural e os meios de vida sustentáveis. Alguns recursos, como os 
alimentos, podem ser substituídos anualmente, pelo crescimento sazonal das plantas, constituindo dessa forma recursos renováveis; enquanto isso outros bens como minerais, carvão e petróleo, são recursos não renováveis, que se esgotam porque o planeta contém quantidades fixas, que estão sendo continuamente consumidas. (SKINNER, 1996 p.1).

Segundo HOUAISS; VILLAR (2001) a palavra recurso pode significar "riqueza, fundos ou meios de que se pode dispor". Para WTO (2010) recursos naturais são "estoques de materiais existentes em ambiente natural que são escassos e economicamente úteis". Ou seja, se forem usados de forma excessiva, terminarão. Neste caso, é necessário saber qual é a disponibilidade para o presente, estimando o futuro. (SKINNER, 1996 p.11).

O homem aprendeu a extrair os recursos de que necessita, de todos os locais acessíveis da Terra, inclusive dos oceanos e da atmosfera. A exploração atual projetada dos recursos terrestres, somada à dispersão dos seus resíduos, é tão grande, que é preciso dar-lhes atenção além de limites geográficos e ambientes locais, para que se tenha uma visão realista de suas quantidades totais. A fim de ordenar tais suprimentos, em perspectiva correta, deve-se examinar as principais feições do planeta. Alimentos, fibras naturais como algodão e produtos florestais tais como madeira e polpa para papel são derivados de plantas, que se regeneram sazonalmente e, por isso, constituem recursos renováveis. A planta em crescimento remove dióxido de carbono da atmosfera e, pelo processo da fotossíntese, usa a energia do Sol para combiná-lo com água do solo, produzindo carboidratos e oxigênio, sendo este último liberado para a atmosfera. Os carboidratos de plantas são alimentos básicos de todos os animais, incluindo o homem, tanto por consumo direto como indireto, através do consumo de animais herbívoros. O consumo de plantas pelos animais é, essencialmente, um processo de decomposição, no qual os carboidratos são novamente reduzidos à água e dióxido de carbono, por meio do oxigênio da atmosfera. Deste modo, a razão química pela qual os animais respiram oxigênio é queimar seu suprimento de alimento contendo carboidratos. A energia retida pela planta em crescimento, durante a fotossíntese é liberada no processo de decomposição e fornece a energia necessária à vida animal. O processo de crescimento e consumo é cíclico; similarmente o mesmo dióxido de carbono e água podem ser utilizados indefinidamente. $\mathrm{O}$ único componente do ciclo que não volta ao seu estado inicial é a energia solar, que pode ser considerada inesgotável. No horizonte de vida do homem, desde que os solos e a água que nutrem as colheitas sejam adequadamente cuidados e recompostos, o suprimento de alimentos, fibras e produtos florestais fornecidos não deve se esgotar. (CAVALCANTI; FURTADO, 1995 p.139; SKINNER, 1996 p.2 e 12). 
Embora a produção de recursos alimentares possa ser ilimitada, há um limite para a capacidade de produção anual. As plantas apenas se desenvolvem em uma zona restrita, onde a atmosfera encontra a superfície da Terra - zona na qual os ingredientes essenciais: dióxido de carbono, água e energia solar estão disponíveis nas proporções necessárias. A superfície terrestre tem área fixa e a razão pela qual a energia solar que a atinge é constante, de modo que estes dois valores preestabelecidos limitam a razão máxima de produção de alimentos vegetais. Apesar de ser possível utilizar a superfície de maneira mais efetiva e, talvez, desenvolver plantas que utilizem a energia solar com maior eficiência do que as atuais, os limites fixados pela área e quantidade de energia permanecerão. Porém, a população da terra cresce continuamente desde o aparecimento do homem e atualmente ela aumenta numa taxa muito superior àquela dos alimentos vegetais. Mesmo que se façam esforços enormes para expandir a produção de alimentos de todas as fontes, inclusive dos oceanos, é inevitável que a população pare de crescer algum dia, ou então o consumo de alimentos ultrapassará a razão de produção. (MARTINE, 2007 p.182; SKINNER, 1996 p.3).

O atual nível de população da terra não teria sido atingido, se não existisse o complexo sistema de controle de saúde, distribuição de energia, transporte e comunicação, que constitui a infraestrutura da civilização. Similarmente, existe uma infraestrutura dos minerais e combustíveis, que é imprescindível. Esses materiais, no entanto, ao contrário dos produtos vegetais, não se formam por meio de rápidos processos cíclicos e não podem ser regenerados, uma vez minerados ou retirados. A Terra contém quantidades fixas de todos os recursos nãorenováveis que, em sua maioria, podem ser utilizados apenas uma vez. Carvão e óleo queimados, fertilizantes fosfáticos distribuídos e argilas transformadas em tijolos são permanentemente consumidos. Até mesmo os metais como ferro, chumbo e cobre, que podem ser recuperados como sucata, sofrem perdas após cada ciclo de uso e a longo prazo estarão irremediavelmente perdidos. O consumo de alguns recursos não-renováveis não é permanente. (SKINNER, 1996 p.4).

O consumo de recursos minerais em diferentes áreas geográficas não é uniforme, devido ao desenvolvimento irregular da industrialização através do mundo. A simples elevação do consumo mundial per capita de todos os recursos minerais, ao nível atualmente desfrutado pela população dos Estados Unidos, abalaria severamente as reservas conhecidas de muitos metais. Para enfrentar o crescimento do consumo per capita e de população, torna-se necessário 
apreciar e compreender a natureza dos recursos conhecidos e potenciais. (SKINNER, 1996 p.67). A taxa de crescimento do consumo varia entre os minerais. Nem todas as taxas de consumo aumentam constantemente de ano para ano, porque ocorrem flutuações curtas, que podem provocar oscilações. (MARTINE, 2007 p.183; SKINNER, 1996 p.6).

Os diferentes tipos de recursos podem ser classificados com base em seu uso. Primeiramente existem elementos químicos de utilidade devido às suas propriedades metálicas. Estes podem ser subdivididos em dois grupos com base em sua ocorrência - aqueles relativamente abundantes na crosta terrestre, como ferro, alumínio, manganês e titânio, e aqueles relativamente escassos, como cobre, chumbo e zinco. Em segundo lugar, há os materiais nãometálicos, que podem ser subdivididos em diferentes grupos, de acordo com seu uso (SKINNER, 1996 p.7-8). Mediante isso, faz-se necessário analisar os recursos naturais utilizados no processo de produção e consumo de alimentos (em especial na pecuária), processos regenerativos e seus atuais níveis.

\subsubsection{Atmosfera}

A atmosfera é continuamente misturada, por ser gasosa e apresentar composição uniforme; é acessível e, portanto, fácil de amostrar. A composição atmosférica é relativamente simples, sendo conhecida com precisão considerável, por isso a estimativa das abundâncias dos vários gases atmosféricos pode ser colocada na categoria de reservas medidas. Três gases - nitrogênio, oxigênio e argônio - perfazem 99,9\% do volume da atmosfera, sendo o nitrogênio um componente básico de fertilizantes vegetais, seu mais importante constituinte. (LEACH et al., 2012). Oxigênio e argônio, juntamente com os gases raros, neônio, xenônio e criptônio, são recuperados da atmosfera, mas em quantidades relativamente pequenas; a utilização dos gases não os remove permanentemente, o que permite classificá-los como recursos utilizáveis. Devido às pequenas quantidades utilizadas, a remoção temporária não tem efeitos sobre a composição da atmosfera, que constitui fonte inesgotável dos poucos elementos nela concentrados. (SKINNER, 1996 p.14). Segundo BITTENCOURT (2012), a agricultura afeta a qualidade do ar e a atmosfera de quatro maneiras: produção de dióxido de carbono devido às queimadas; metano oriundo da produção de arroz e animais; óxido nitroso oriundo de fertilizantes e esterco; e amônia de esterco e urina. Na tabela 5 é possível identificar que a emissão de metano tem se mostrado constante, ao contrário do óxido nitroso que se mostra em 
crescimento. A queima de biomassa, realizada para a limpeza do solo para plantio emite substâncias poluentes para a atmosfera e essa é uma prática bastante comum na agricultura tropical, seja para estimular o desenvolvimento de forragens para os rebanhos, seja para limpar o terreno para novos plantios, principalmente no caso do arroz, mas cuja poluição se estende para regiões além da origem das queimadas. (BITTENCOURT, 2012 p.134).

Tabela 5: Emissões de Metano e Óxido Nitroso Agrícolas (\% do total)

\begin{tabular}{|l|l|l|l|l|l|}
\hline & $\mathbf{1 9 9 0}$ & $\mathbf{2 0 0 0}$ & $\mathbf{2 0 0 5}$ & $\mathbf{2 0 0 8}$ & $\mathbf{2 0 1 0}$ \\
\hline Metano & 47,65 & 45,93 & 43,36 & 43,61 & 42,53 \\
\hline Óxido Nitroso & 63,58 & 64,98 & 65,29 & 69,11 & 70,13 \\
\hline
\end{tabular}

Fonte: desenvolvido pela autora com base em WORLD BANK (2014a) e WORLD BANK (2014b)

\begin{tabular}{|c|c|c|c|c|c|}
\hline & $\begin{array}{l}\text { Dioxido de } \\
\text { Carbono }\end{array}$ & Metano & Óxido Nitroso & Óxido Nitrico & Amônia \\
\hline Efeitos & $\begin{array}{l}\text { Mudanças } \\
\text { Climáticas }\end{array}$ & $\begin{array}{l}\text { Mudanças } \\
\text { Climáticas }\end{array}$ & $\begin{array}{l}\text { Mudanças } \\
\text { Climáticas }\end{array}$ & Acidificação* & $\begin{array}{l}\text { Acidificação e } \\
\text { Eutrofização* }\end{array}$ \\
\hline $\begin{array}{c}\text { Uso na } \\
\text { Agricultura e } \\
\text { Contribuição } \\
\text { estimada no total } \\
\text { de emissões } \\
\text { globais }\end{array}$ & $\begin{array}{c}\text { Mudança no uso } \\
\text { da terra, } \\
\text { especialmente } \\
\text { desflorestamento }\end{array}$ & $\begin{array}{l}\text { Ruminantes (15\%) } \\
\text { Produção de Arroz } \\
\qquad 11 \%) \\
\text { Queima de } \\
\text { Biomassa (7\%) }\end{array}$ & $\begin{array}{c}\text { Pecuária (incluindo } \\
\text { o estrume aplicado } \\
\text { a terra) } \\
\text { Fetilizantes } \\
\text { Minerais (8\%) } \\
\text { Queima de } \\
\text { Biomassa (3\%) }\end{array}$ & $\begin{array}{l}\text { Queima de } \\
\text { Biomassa } \\
\text { Estrume e } \\
\text { Fertilizantes } \\
\text { Minerais (2\%) }\end{array}$ & $\begin{array}{c}\text { Pecuária (incluindo } \\
\text { o estrume aplicado } \\
\text { a terra) } \\
\text { Fetilizantes } \\
\text { Minerais (17\%) } \\
\text { Queima de } \\
\text { Biomassa (11\%) }\end{array}$ \\
\hline $\begin{array}{c}\text { Emissões } \\
\text { agrícolas de } \\
\text { fontes } \\
\text { antropogênicas** } \\
\text { (\% do total) }\end{array}$ & $15 \%$ & $49 \%$ & $66 \%$ & $27 \%$ & $93 \%$ \\
\hline $\begin{array}{l}\text { Mudanças } \\
\text { esperadas nas } \\
\text { emissões } \\
\text { agrícolas para } \\
2030\end{array}$ & $\begin{array}{c}\text { Estável ou em } \\
\text { Declínio }\end{array}$ & $\begin{array}{l}\text { Arroz: Estável ou } \\
\text { em Declínio } \\
\text { Pecuária: Aumento } \\
\text { de } 60 \%\end{array}$ & $\begin{array}{c}\text { Aumento entre } \\
35 \%-60 \%\end{array}$ & & $\begin{array}{c}\text { Pecuária: Aumento } \\
\text { de } 60 \%\end{array}$ \\
\hline
\end{tabular}

Fonte: Adaptado de BITTENCOURT (2012)

Para alguns países a emissão de gases do efeito estufa pela agricultura representa importante parcela do total de emissões, apesar deste ser raramente o tipo de emissão dominante. Esta participação da emissão de gases pela agricultura pode crescer à medida que as emissões derivadas da produção industrial e de energia crescem menos rapidamente. Existe também a preocupação com outras fontes de emissão, como a de metano, ácido nitroso, e amônia, (expostos na tabela 6) os quais, em alguns países podem representar cerca de $80 \%$ do total de 
emissões de gases do efeito estufa pela agricultura. (MORILHAS; SCATENA; MACEDO, 2009).

\subsubsection{Hidrosfera}

A hidrosfera, contemplando o recurso mineral mais importante de todos, indispensável à produção de alimentos e manutenção das atividades humanas, é considerada um corpo de água condensada sobre ou próximo a superfície da Terra. Na hidrosfera podem ser encontrados outros recursos vitais: os oceanos, que cobrem $70,8 \%$ da superfície da Terra, com profundidade média de 3,93 quilômetros, que atuam como coletores para muitos dos materiais solúveis carregados dos continentes, retirados por intemperismo das rochas e solos, e aqueles provenientes de emanações vulcânicas. Através dos tempos, os oceanos atingiram a composição atual, com 3,5\% em peso de sólidos dissolvidos. Esse conteúdo de sólidos corresponde aproximadamente, a 38,4 x $10^{6}$ toneladas de material, em cada quilômetro cúbico de água do mar; e nas proporções relativas, entre os principais elementos em solução, são essencialmente constantes em todos os oceanos. Sódio e cloro, os dois elementos que constituem o sal comum (de cozinha) são os mais abundantes e, juntamente com magnésio, enxofre, cálcio e potássio, constituem $99,5 \%$ do total de sólidos dissolvidos no mar. Cada quilômetro cubico de água do mar contém ainda quantidades significativas de outros 64 elementos, como zinco, 11,3 toneladas; cobre e estanho, 3,4 toneladas cada; prata 0,24 toneladas; ouro, 430 gramas. (SKINNER, 1996 p.15). Apesar da variedade de elementos presente na água do mar, apenas quatro deles estão sendo recuperados comercialmente em quantidades significativas: sódio e cloro (recuperados como cloreto de sódio) magnésio e bromo. (DE CHARDIN, 2005 p.77; SKINNER, 1996 p.16).

Embora exista certa parcela de água presa nos minerais da crosta, é com a água livre da hidrosfera que o homem supre suas necessidades. Sua quantidade total é estimada em $1359 \mathrm{x}$ $10^{6}$ quilômetros cúbicos ou $1359 \times 10^{18}$ litros distribuídos de maneira muito irregular: 97,2\% estão nos oceanos e 2,15\% retidos nas calotas polares e geleiras. Estes dois maiores reservatórios são de pequena utilidade prática, a não ser como meio de transporte; os oceanos são muito salgados, as calotas de gelo muito distantes e os custos de transformação ou recuperação muito elevados para justificar seu uso em grande escala. A água restante da hidrosfera, $0,65 \%$ é a fração utilizada pelo homem e seria rapidamente consumida se não 
existisse o ciclo hidrológico. Este ciclo movido pela energia solar consiste na evaporação e transpiração, seguida de condensação e precipitação; ele assegura um suprimento contínuo, motivo pelo qual a água constitui um recurso renovável que envolve problemas de abundancia, distribuição e abastecimento. (SKINNER, 1996 p. 119).

Na figura 5 é possível identificar que em torno de $69 \%$ da água no mundo é extraída para o setor agrícola, aproximadamente 16\% é utilizada de forma industrial e apenas 15\% utilizada de forma municipal ou para o saneamento e alimentação da população. (UNESCO-WWAP, 2012 p.5).

Figura 5: Extrações de Água por setor e região

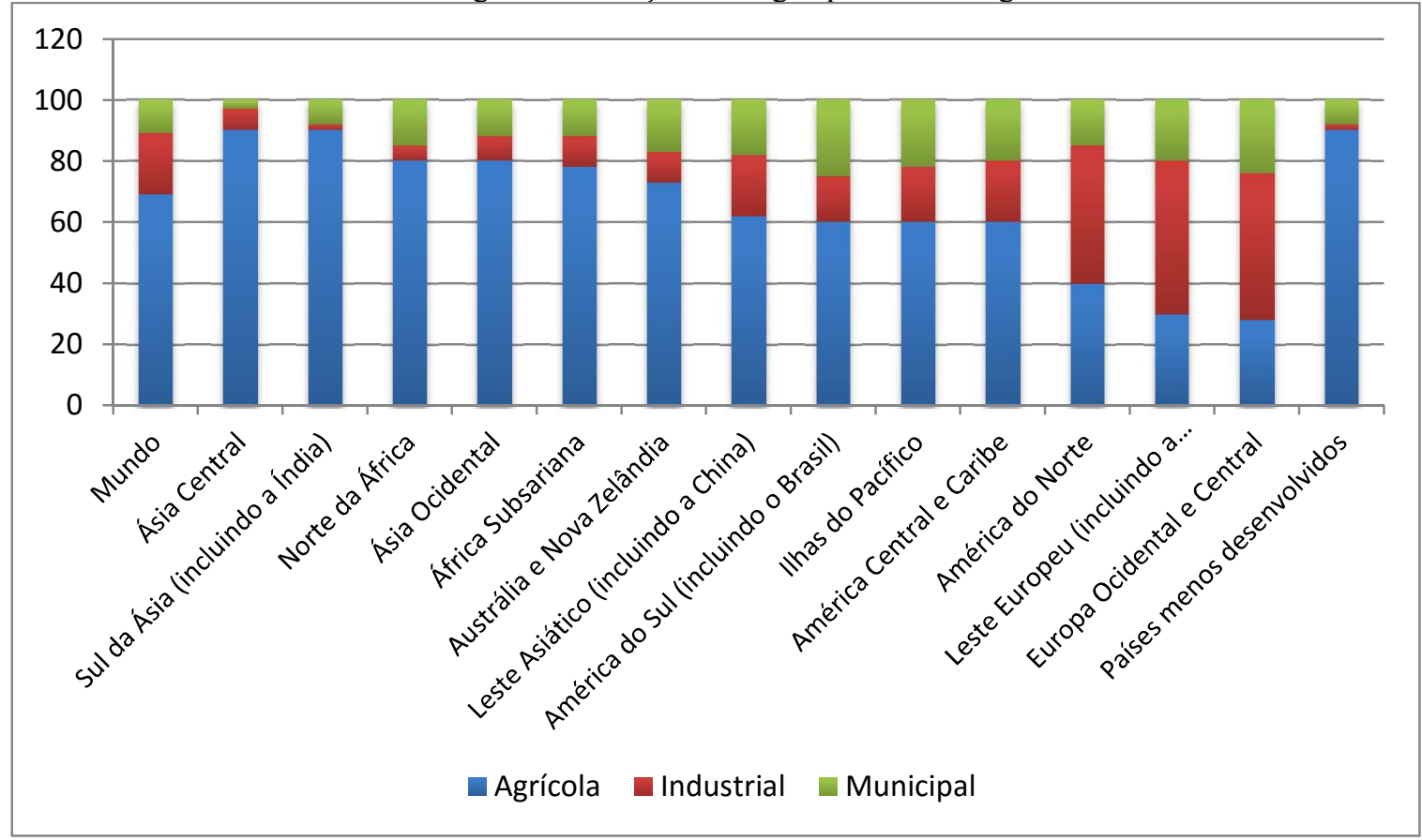

Fonte: FAO. AQUASTAT online data-base in UNESCO-WWAP (2012)

Apesar da chuva constituir o único suprimento constante de água, existe um reservatório temporário muito importante à disposição do homem. Qualquer ocorrência aquífera do subsolo é denominada água de subsuperfície; o qual constitui um recurso muito importante, mas infelizmente a sua reposição é bastante lenta, sendo que a retirada excessiva de água pode causar a exaustão local. Abaixo da superfície do terreno, existe uma zona em que todos os poros e cavidades das rochas se apresentam saturados por água subterrânea, cujo limite superior constitui o nível hidrostático. Este nível sempre existe, podendo aflorar na superfície, como no caso dos lagos e rios, ou encontrar-se a mais de uma centena de metros de profundidade. A 
água existente abaixo do nível hidrostático move-se por infiltração, fluindo lentamente para os oceanos. Este percurso no subsolo pode ser comparado a um grande rio, de fluxo extremamente lento, no qual a água pode permanecer de algumas horas a milhares de anos, antes de atingir os oceanos. O nível hidrostático é irregular, devido à resistência oferecida pelas rochas ao fluxo de água e tende a refletir o relevo superficial. (SKINNER, 1996 p. 123 e 125).

As águas subterrâneas são essenciais para a sobrevivência e para a segurança alimentar de regiões mais pobres da África e da Ásia, mas também para o fornecimento doméstico de uma grande parte da população do restante do mundo. (UNESCO-WWAP, 2012 p.5). O volume global de águas subterrâneas armazenadas é pouco conhecido, porém as estimativas variam entre 15,3 milhões e 60 milhões de $\mathrm{km}^{3}$, incluindo os oito milhões a dez milhões de $\mathrm{km}^{3} \mathrm{de}$ água doce. (UNESCO-WWAP, 2012 p.6).

Acima do nível hidrostático existe uma região insaturada que contém a água vadosa. Próximo à superfície há uma zona rica em raízes de vegetais que contém a água do solo; esta não tem mobilidade, permanecendo estática pela aderência a superfície dos grãos minerais. Pouco abaixo, mas ainda na zona insaturada, a água vadosa flui lentamente em direção ao corpo de água subterrânea. A água vadosa não pode ser considerada um recurso, embora seja responsável pela reposição - muito lenta - da água subterrânea retirada. (SKINNER, 1996 p. 125). Até o ano de 2010, o agregado de captação das águas subterrâneas mundiais está estimado em cerca de $1.000 \mathrm{~km}^{3}$ por ano, e aproximadamente $67 \%$ dessas águas são usadas para irrigação, $22 \%$ para fins domésticos e 11\% para fins industriais. Ao longo dos últimos cinquenta anos houve aumento em pelos menos três vezes e o aumento é progressivo de $1 \%$ a $2 \%$ ao ano. As estimativas indicam que a captação das águas subterrâneas seja responsável por $26 \%$ da retirada total de água no mundo. (UNESCO-WWAP, 2012 p.6). Embora a água seja um recurso renovável, há quem estime que no ano 2.100, caso o comportamento de uso não seja alterado, ela acabe. (MEADOWS, D. et al., 2004 p.69).

\subsubsection{Crosta Terrestre}

A crosta terrestre é constituída por muitos tipos diferentes de rochas e minerais. Oxigênio, silício, alumínio, ferro, magnésio, cálcio, potássio e sódio são alguns dos principais componentes encontrados na litosfera e alguns deles são utilizados como importantes elementos na produção de alimentos. Os diferentes arranjos cristalinos e combinações químicas destes elementos produzem a diversidade de rochas e minerais. A crosta da Terra supre a maior parte 
dos recursos minerais, apresentando diferenças óbvias e importantes em relação à hidrosfera e à atmosfera. Em primeiro lugar, ela é constituída predominantemente de minerais que são sólidos cristalinos de composição bastante simples. Em segundo lugar, nota-se na natureza, que os minerais não estão sendo distribuídos ao acaso, mas concentrados em depósitos e rochas especificas. Os elementos químicos da crosta não se distribuem de maneira uniforme como na atmosfera e oceanos, mas ao invés disso estão distintamente segregados. Desse modo, mesmo os elementos que apresentam pequena concentração média na crosta podem ser encontrados em acumulações locais muito ricas. (SKINNER, 1996 p.17).

Tabela 7: Minérios de maior importância

\begin{tabular}{|c|c|c|c|}
\hline Classificação & Mineral & Característica & Aplicação na Agricultura \\
\hline \multirow{6}{*}{$\begin{array}{c}\text { Recursos } \\
\text { Minerais } \\
\text { Metálicos } \\
\text { (abundantes e } \\
\text { raros) }\end{array}$} & $\begin{array}{l}\text { Ferro (magnetita, } \\
\text { hematita) }\end{array}$ & $\begin{array}{l}\text { É o principal elemento na composição do aço. Utilizado } \\
\text { para produzir ferramentas, máquinas, pontes e etc. }\end{array}$ & Fertilizante \\
\hline & Alumínio (bauxita) & $\begin{array}{l}\text { Possui uma boa condução de calor e maleabilidade. } \\
\text { Utilizado para produção de automóveis, aviões, cabos, } \\
\text { planelas e etc. }\end{array}$ & \\
\hline & $\begin{array}{l}\text { Manganês } \\
\text { (pirolusita) }\end{array}$ & $\begin{array}{l}\text { Presente na composição do aço. Utilizado na siderurgia, } \\
\text { fabricação de pilhas, trilhos e etc. }\end{array}$ & Fertilizante \\
\hline & Chumbo (galena) & $\begin{array}{l}\text { Metal não-abundante. Utilizado em tubulações, baterias, } \\
\text { placas, isolante de radiação e munição. }\end{array}$ & \\
\hline & $\begin{array}{l}\text { Cobre (calcopirita, } \\
\text { malaquita) }\end{array}$ & $\begin{array}{c}\text { É combinado ao estanho na formação do bronze. } \\
\text { Utilizado na produção de cabos elétricos, peças } \\
\text { automotivas, fios e etc. }\end{array}$ & \\
\hline & Estanho (cassiterita) & Utilizado na produção de ligas e folhas de flandres & \\
\hline \multirow{3}{*}{$\begin{array}{l}\text { Recursos } \\
\text { Minerais Não- } \\
\text { Metálicos }\end{array}$} & Diamante & $\begin{array}{c}\text { Utilizado na fabricação de jóias e pontas de brocas } \\
\text { usadas na perfuração de poços artesianos }\end{array}$ & \\
\hline & Calcário & Utilizado na produção de cimento, cal, giz e etc. & Fertilizante \\
\hline & Areia & Utilizada na produção de vidro e concreto & \\
\hline
\end{tabular}

Fonte: Elaborada pela autora baseado em SKINNER (1996)

Os metais podem ser divididos em duas classes (destacados na tabela 7), em função de sua ocorrência na crosta: os metais raros, de abundância inferior a $0,01 \%$ e os metais abundantes - ferro, alumínio, manganês, cromo e titânio - de abundância superior a 0,01\%. (SKINNER, 1996 p.19).

\subsubsection{Minerais}

Mineral é um corpo natural sólido e cristalino formado em resultado da interação de processos físico-químicos em ambientes geológicos. Cada mineral é classificado e denominado não apenas com base na sua composição química, mas também na estrutura cristalina dos materiais que o compõem. (KLEIN; DUTROW, 2009 p.28). 
Ao contrário dos metálicos, os minerais não-metálicos não podem ser facilmente classificados em termos de abundância na crosta; permitem, no entanto, uma classificação baseada em seus usos. Os minerais utilizados principalmente em fertilizantes e produtos químicos em geral (utilizados na agricultura) correspondem a 33\% do valor da produção de não-metálicos. (SKINNER, 1996 p.69).

Os minerais para fertilizantes constituem um recurso extremamente vital, essencial ao aumento da produção de alimentos, necessário a população humana em expansão. Felizmente a maioria dos compostos necessários é abundante e largamente distribuída, não havendo ameaças de possível exaustão. (NASCIMENTO, 2004; SKINNER, 1996 p.69).

O ciclo de crescimento das plantas necessita de muitos elementos químicos. Oxigênio e hidrogênio (os dois constituintes da água) juntamente com o carbono (derivado do dióxido de carbono da atmosfera) perfazem $98 \%$ do peso dos vegetais. No entanto, nitrogênio, fósforo, potássio, cálcio e enxofre também são essenciais às plantas terrestres - que representam a fonte principal de alimento do solo. A disponibilidade desses elementos determina, em parte, o crescimento vegetal, devendo apresentar-se em forma solúvel, assimilável pelas plantas. A maioria dos solos, por exemplo, contem $1 \%$ ou mais de potássio que não pode ser utilizado pelas plantas, pois está sob forma de minerais insolúveis aluminosos ou silicatados, como os feldspatos. Portanto, para aumentar o crescimento dos vegetais, pela adição de um fertilizante potássico, frequentemente adiciona-se esse elemento na forma de cloreto, seu composto solúvel mais abundante. (SKINNER, 1996 p.70).

\subsubsection{Metais}

Os metais apresentam características peculiares e versáteis, tais como maleabilidade, ductilidade, brilho, alta condutividade térmica e elétrica. São de valor incalculável nas aplicações tecnológicas, tendo-se tornado o padrão pelo qual os arqueólogos e historiadores costumam avaliar o desenvolvimento de uma comunidade em função da habilidade com que são trabalhados. (SKINNER, 1996 p.19).

Definimos como metais geoquimicamente raros aqueles com abundância inferior a $0,01 \%$ na crosta. É interessante saber que o cobre, o chumbo, o zinco e o níquel, explorados em escala 
grande e crescente, são geoquimicamente raros, pertencendo à mesma categoria que o ouro, a prata e a platina. Porém, a maioria dos especialistas acredita que é neste grupo de recursos que o déficit aparecerá em primeiro lugar, constituindo um sério desafio ao desenvolvimento tecnológico. Os elementos raros pertencem ao grupo de recursos vitais que acelerou o importante desenvolvimento tecnológico dos últimos cem anos, especialmente na obtenção e distribuição de energia elétrica; comunicações por telégrafo, rádio e televisão, aeronáutica, foguetes e energia nuclear. (SKINNER, 1996 p.42).

\subsubsection{Fertilizantes}

Os fertilizantes são essenciais para a agricultura moderna e para a produção de alimentos. A eficácia dos fertilizantes nitrogenados, fosfáticos e outros depende igualmente da sua solubilidade. Os recursos minerais mais procurados para a obtenção e fertilizantes são, portanto, os compostos naturais solúveis ou aqueles que podem ser tornados solúveis, com um mínimo de tratamento. (SKINNER, 1996 p.70).

O potássio é um dos fertilizantes essenciais, ao lado do fósforo e nitrogênio. Rochas ou minerais que apresentem teores elevados de potássio poderão ser fontes alternativas potenciais para produção de sais de potássio e/ou de termofosfatos potássicos ou ainda para aplicação direta nos solos como fertilizantes de potássio de solubilização lenta. (NASCIMENTO, 2004 p.13). Não causa surpresa, portanto, o fato do consumo mundial de sais de potássio aumentar em quase 10\% ao ano, como consequência da crescente demanda de alimentos. (SKINNER, 1996 p.71). O potássio, como um elemento abundante, possui grande distribuição nos minerais silicáticos. No caso de fertilizantes, no entanto, é procurado sob forma de alguns minerais solúveis, praticamente confinados a uma classe especial de depósitos minerais, conhecidos como evaporitos marinhos. Esses são resultantes da acumulação de sais, pela evaporação de água do mar. (SKINNER, 1996 p.71).

O ciclo do fósforo é o mais afetado pelo cultivo intenso da terra. É um elemento vital a vários processos do corpo humano, acumulando-se principalmente no esqueleto sob forma do mineral apatita, que não retorna ao solo após a morte. Esse fato torna imprescindível a sua aplicação como fertilizante. (SKINNER, 1996 p. 75). 
O nitrogênio é o principal recurso obtido na atmosfera. Ele é fornecido ao solo na forma de nitrato solúvel ou ainda em compostos amoniacais. (SKINNER, 1996 p. 77). O uso de fertilizantes nitrogenados tem aumentado. Algumas das razões desse aumento da utilização podem ser atribuídas à expansão de terras agrícolas e o aumento da produtividade devido ao uso de variedades de maior rendimento, que também têm índices mais altos de colheita. (ODEGARD, INGRID YM RUTH, 2011 p.49). Porém o uso humano de nitrogênio reativo $\left(\mathrm{N}_{\mathrm{r}}\right)$ no ambiente resulta em profundos impactos benéficos e prejudiciais. Seus impactos benéficos resultam da produção de alimentos e aplicação industrial. Os impactos negativos ocorrem porque a maior parte do $\mathrm{N}_{\mathrm{r}}$ utilizado na produção de alimentos e de toda a quantidade de $\mathrm{N}_{\mathrm{r}}$ formado durante a combustão de combustíveis fósseis são perdidos com o ambiente, e assim uma cascata de mudanças ambientais são provocadas, as quais impactam negativamente as pessoas e os ecossistemas. (LEACH et al., 2012 p.40). No entanto, segundo GALLOWAY et al. (2007), algumas medidas de gestão de custos de recursos naturais podem ser realizadas para a conservação da terra, como por exemplo o uso eficaz da água e de nitrogênio na produção pecuária com menores impactos.

Devido as suas inúmeras aplicações, o enxofre não é lembrado como elemento fertilizante; no entanto, $40 \%$ da produção mundial é utilizada na obtenção de superfosfato de amônia, ambos fertilizantes essenciais. A indústria química utiliza apenas $20 \%$ em grande parte na produção de inseticidas e fungicidas para proteção agrícola. (SKINNER, 1996 p. 77).

Figura 6: Consumo de Fertilizantes

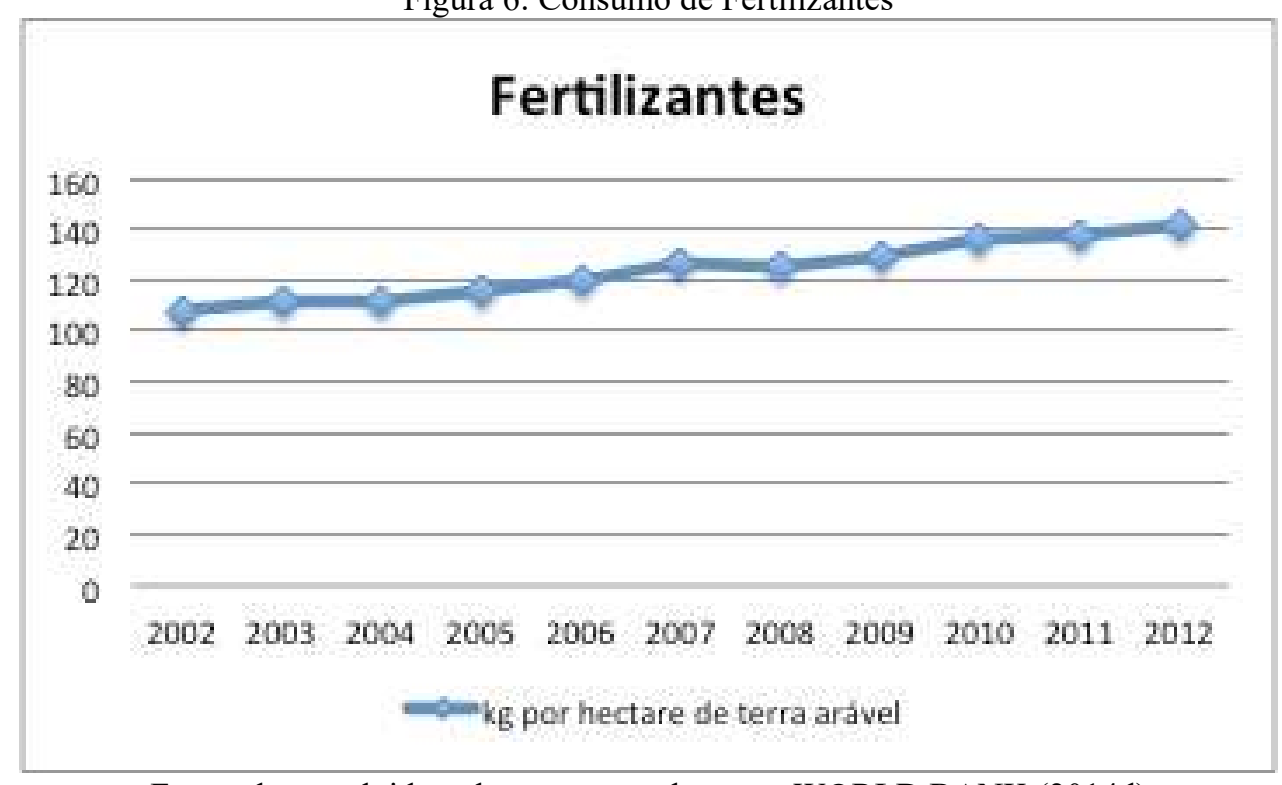

Fonte: desenvolvido pela autora com base em WORLD BANK (2014d) 
A figura 6 indica que o consumo de fertilizantes cresce a cada ano e seguindo esse histórico há uma tendência de intensificação de seu uso. Segundo MAY (2010), nas principais categorias de impactos ambientais relacionados ao cultivo agrícola estão presentes os fertilizantes, causando efeitos na saúde humana, contaminação na água e em produtos alimentícios e perdas na fauna, flora silvestres e diversidade biológica.

Nesse subtítulo foi possível analisar os recursos naturais, disponibilizados pelo planeta, e aplicados na pecuária. A seguir, foram discutidos os métodos de criação, nos quais são utilizados os recursos naturais mencionados anteriormente, juntamente com variáveis influenciadoras da produção e seus principais indicadores.

\subsection{Produção Bovina de Corte}

De acordo com dados da FAOSTAT (2014) mostrados nas Figura 7 e 8, verifica-se que, em 2014, de um total de 1,4 bilhão de cabeças, $44 \%$ de sua concentração está dividida entre Brasil (14\%) Índia (13\%), na China (8\%) e nos Estados Unidos (6\%). Entre os três principais rebanhos bovinos comerciais (Brasil, Estados Unidos e China), o brasileiro foi o que apresentou maior taxa de crescimento no período de 1993 a 2014.

Figura 7: Criação bovina mundial (em cabeças)

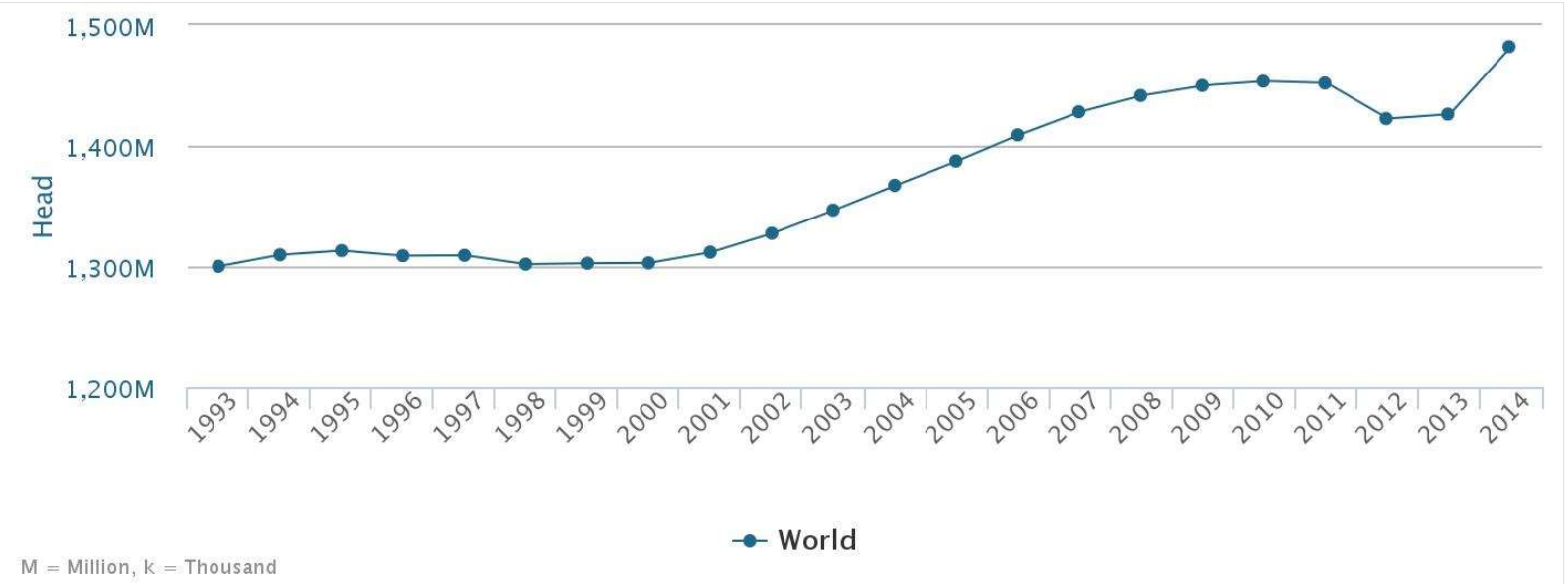

Fonte: desenvolvido pela autora com base em FAO (2014a) 
Figura 8: Maiores criadores bovinos (em cabeças)

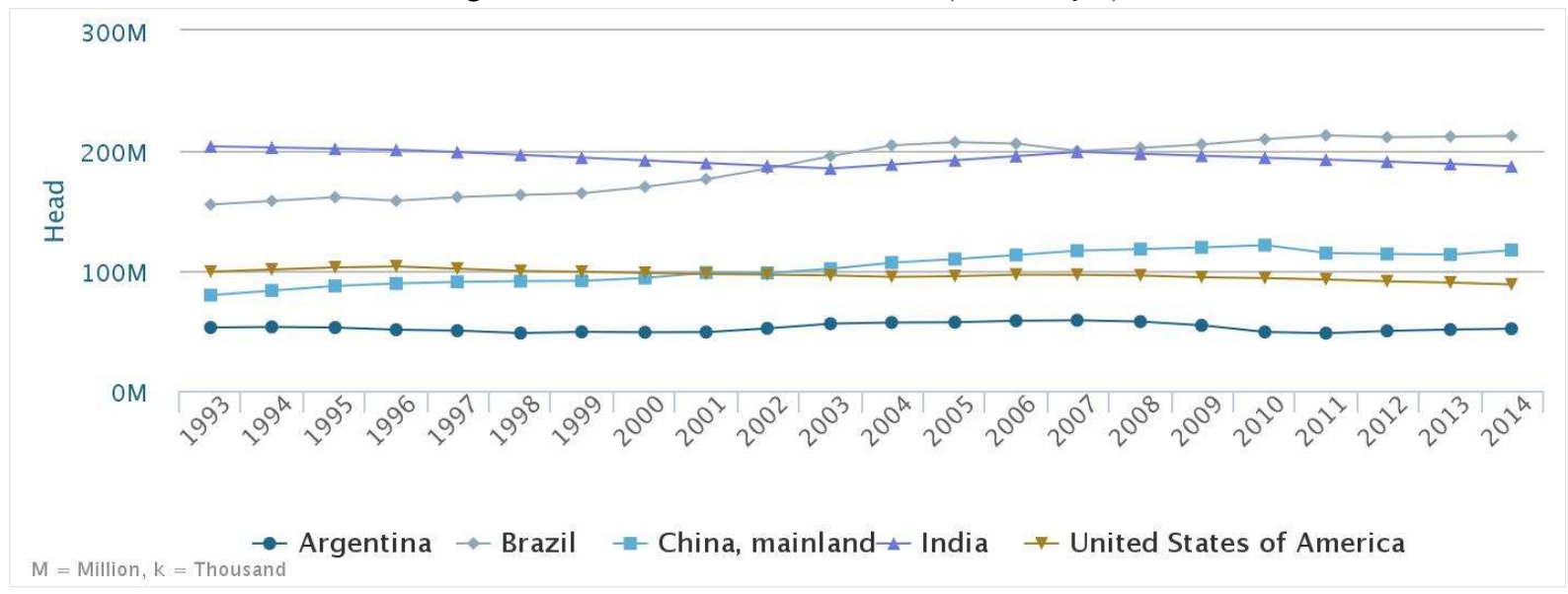

Fonte: desenvolvido pela autora com base em FAO (2014a)

Na figuras 9 e 10, verifica-se que em 2013, de um total de 63 milhões de toneladas de carne produzidas, $48 \%$ de sua concentração está dividida entre 4 dos 5 maiores criadores bovinos: Estados Unidos (18\%), Brasil (15\%), China (10\%) e Argentina (4\%).

Figura 9: Produção de carne bovina (em toneladas)

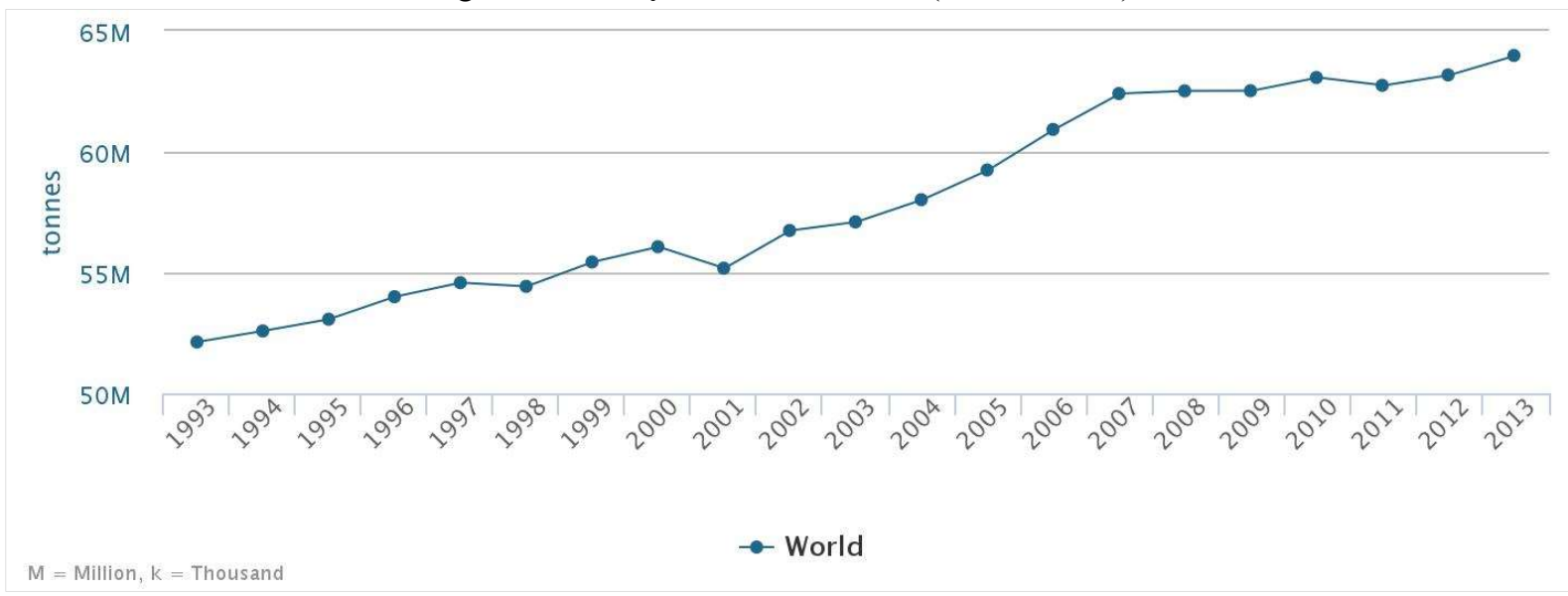

Fonte: desenvolvido pela autora com base em FAO (2014a) 
Figura 10: Maiores produtores de carne bovina (em toneladas)

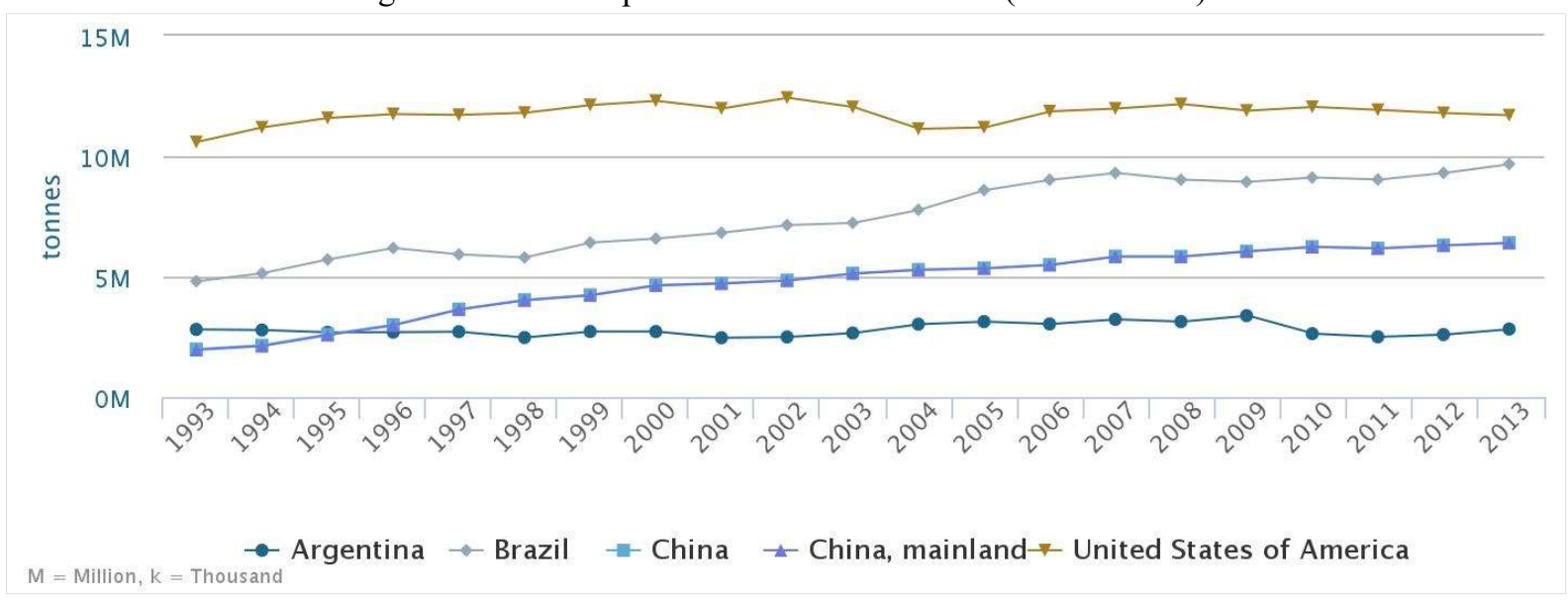

Fonte: desenvolvido pela autora com base em FAO (2014a)

Em virtude de o Brasil estar presente tanto no ranking dos maiores criadores bovinos como no dos maiores produtores de carne bovina, ele será considerado uma referência para a análise desse estudo, nos quesitos de produção e produtividade pecuária. Considerando o total do rebanho bovino brasileiro, cerca de $90 \%$ é constituído de gado de corte, cujo sistema de produção destina-se à produção de carne.

Para efeitos dessa pesquisa, os dados de produção brasileira (indicados na figura 11) foram selecionados como parâmetros, uma vez que o país possui o segundo maior rebanho bovino do mundo e o primeiro maior rebanho comercial. O país é também o terceiro maior exportador de carne em toneladas e em faturamento. (BEEF2LIVE, 2015a;2015b). 
Figura 11: Perfil Brasileiro de Produção Bovina

\section{PERFIL BRASILEIRO \\ DE PRODUÇÃO BOVINA}

Importação de animais vivos 273 cabeças

Peso Médio de Carcaça: 239,50Kg

Rendimento Médio

Caraça (Zebu):

$52,3 \% \sim 55 \%$

EXPORTAÇÃO $(20,77 \%)$

2,09 milhões TEC
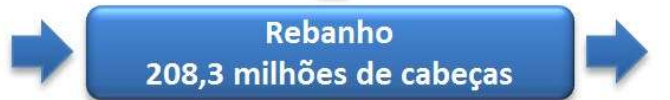

Exportação de animais vivos

681.312 cabeças

Desfrute: $20,11 \%$

Confinamentos:

2,02 milhões de cabeças

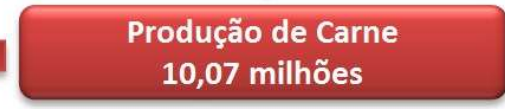

TEC $=$ Toneladas Equivalente Carcaça

Fonte: ABIEC (2014)

O sistema de produção de gado de corte tem como característica a aplicação de um conjunto de tecnologias e práticas de manejo, bem como o tipo de animal, o propósito da criação, a raça ou agrupamento genético e a ecorregião em que a atividade é desenvolvida.

Tabela 8: Balanço da Pecuária Bovina Mundial

\begin{tabular}{|c|c|c|c|c|c|c|c|c|c|c|c|c|}
\hline \multirow[b]{2}{*}{ Anos } & \multicolumn{2}{|c|}{ Brasil } & \multicolumn{2}{|c|}{ Índia } & \multicolumn{2}{|c|}{ China } & \multicolumn{2}{|c|}{$\begin{array}{l}\text { Estados } \\
\text { Unidos }\end{array}$} & \multicolumn{2}{|c|}{ Austrália } & \multicolumn{2}{|c|}{$\begin{array}{l}\text { União } \\
\text { Européia }\end{array}$} \\
\hline & 2013 & $2014 *$ & 2013 & 2014* & 2013 & $2014 *$ & 2013 & $2014 *$ & 2013 & $2014^{*}$ & 2013 & 2014* \\
\hline $\begin{array}{l}\text { Rebanho Bovino - milhões de } \\
\text { cabeças }\end{array}$ & 211 & 214 & 330 & 332 & 104 & 104 & 88,3 & 86,6 & 28,4 & 29,1 & 87,6 & 87,9 \\
\hline Abate - milhões de cabeças & 46,5 & 42,1 & 37,8 & 40 & 41,3 & 42 & 33,2 & 31,3 & 8,6 & 8,4 & 27,3 & 27,6 \\
\hline Produção de carne $* *$ & 9,1 & 9,9 & 3,75 & 3,95 & 5,63 & 5,75 & 11,7 & 11 & 2,27 & 2,26 & 7,69 & 7,76 \\
\hline Taxa de abate (\%) & 22 & 20 & 11 & 12 & 40 & 40 & 38 & 35 & 30 & 30 & 31 & 31 \\
\hline $\begin{array}{l}\text { Produção de Bezerros - } \\
\text { milhões de cabeças }\end{array}$ & 57,9 & 51,3 & 64,5 & 65,5 & 41,6 & 42,4 & 33,7 & 33,3 & 9,2 & 8,75 & 29,8 & 29,9 \\
\hline Exportações $* * *$ & 1,8 & 1,94 & 1,65 & 1,75 & 0,03 & 0,02 & 1,11 & 1,04 & 1,53 & 1,54 & 0,26 & 0,27 \\
\hline
\end{tabular}

* 2014 - previsões. ${ }^{* *}$ Mil ton eq carcaça. ${ }^{* * *}$ milhões ton eq. carcaça.

Fonte: (CSR/UFMG, 2015)

É possível dizer que o Brasil mantém a liderança mundial em exportação, tanto em quantidade, quanto em volume financeiro (dados indicados nas tabelas 8 e 9). Vários fatores contribuíram 
para o aumento das exportações brasileiras nos últimos anos, entre eles estão aspectos sanitários, melhoria na qualidade e precocidade do rebanho brasileiro, maior demanda de alimentos pelos mercados emergentes e menor custo de produção do produto nacional em relação aos seus maiores concorrentes. (FAO; IFAD; WFP, 2014).

O rebanho, produção de carne, consumo interno e as exportações aumentaram nos últimos anos, apesar do consumo per capita ter estabilizado com ligeira queda no ano de 2013. Há uma perspectiva de aumento do consumo mundial em 1,5\% ao ano, podendo atingir até 76 milhões de toneladas em 2022. Por sua vez, o consumo interno acompanha o crescimento da renda per capita de carne bovina (atualmente de $36 \mathrm{~kg}$, chegando a $59 \mathrm{~kg}$ em 2030), o que refletirá diretamente no crescimento do mercado da carne. (FAO et al., 2014).

Tabela 9: Balanço da Pecuária Bovina de Corte no Brasil

$20052006200720082009201020112012 \quad 2013 \quad 2014^{*}$

\begin{tabular}{|c|c|c|c|c|c|c|c|c|c|c|}
\hline $\begin{array}{l}\text { Rebanho Bovino - milhões de } \\
\text { cabeças }\end{array}$ & 207 & 206 & 200 & 205 & 206 & 211 & 216 & 213 & 211 & 199 \\
\hline Taxa de abate total (\%) & 25,3 & 27,4 & 25,1 & 23,2 & 23,1 & 23,5 & 21,3 & 22,0 & 22,0 & 21,8 \\
\hline Abate (milhões) & 52,4 & 56,4 & 50,1 & 46,9 & 47,5 & 49,2 & 45,3 & 46,6 & 46,5 & 43,3 \\
\hline Taxa de abate de matrizes (\%) & 46,8 & 48,5 & 48,1 & 45,4 & 48,2 & 48,2 & 49,3 & 48,3 & 46,6 & 47,6 \\
\hline Produção de Carne ** & 10,5 & 10,6 & 9,3 & 8,8 & 9,0 & 9,3 & 8,7 & 8,9 & 9,1 & 8,52 \\
\hline Consumo interno * & 6,33 & 6,47 & 5,64 & 5,62 & 6,04 & 6,26 & 6,14 & 6,57 & 6,59 & 6,48 \\
\hline Consumo per capita $* * *$ & 35,0 & 36,0 & 31,0 & 30,0 & 32,0 & 33,0 & 31,7 & 33,5 & 33,0 & 32,0 \\
\hline Exportação ** & 1,86 & 2,1 & 2,2 & 1,83 & 1,61 & 1,55 & 1,32 & 1,5 & 1,8 & 2,1 \\
\hline Importação ** & 43,0 & 25,0 & 26,0 & 24,0 & 30,0 & 30,0 & 35,0 & 55,0 & 53,0 & 62,0 \\
\hline
\end{tabular}

Fonte: (CSR/UFMG, 2015)

\subsubsection{Pastagem}

Os sistemas de produção de carne bovina são, geralmente, divididos em atividades ou fases de cria, recria e engorda, cujos respectivos produtos seriam os bezerros (machos ou fêmeas), os garrotes e novilhas e o boi gordo. Embora haja heterogeneidade quanto à adoção de tecnologias, esses sistemas baseiam-se, quase na sua totalidade, no uso de pastagens. Segundo a Associação Nacional dos Confinadores - ASSOCON, cerca de três milhões de animais são produzidos em sistema de confinamento, alimentados com ração, sem acesso a pasto. (SBA, 2016). 
De acordo com dados da FAO (2014a) existiam, em 2011, dos 275 milhões de hectares dedicados à agricultura no Brasil, 196 milhões (71\%) eram utilizados em pastagens no país para aproximadamente 212 milhões de cabeças de gado, com ampliação da taxa de lotação das pastagens. Uma característica importante da pecuária brasileira é ter a maior parte de seu rebanho criado a pasto, que se constitui na forma mais econômica e prática de produzir e oferecer alimentos para os bovinos. Por conseguinte, as pastagens desempenham papel fundamental na pecuária brasileira, garantindo baixos custos de produção. Enquanto que em países como os Estados Unidos, o confinamento é a base do processo de oferta do alimento para o gado e exige o uso intensivo de mão de obra, máquinas, equipamentos e combustível fóssil, no Brasil essa colheita é realizada pelo próprio animal, por meio do pastejo, com adição da vantagem de não depender de fatores instáveis como altas nos preços de grãos para alimentação do rebanho e resultando na redução de custos, riscos econômicos e impactos ambientais, a melhoria no bem-estar do animal e a geração de um produto tido como mais saudável, com qualidade nutricional elevada, sendo possível o uso do termo mercadológico "boi verde ou de capim", poderoso ingrediente para conquista de mercados exigentes na aquisição de carne. (CARVALHO, T. B. D.; ZEN; TAVARES, 2009; DALEY et al., 2010; DEBLITZ, 2012; DIAS-FILHO, 2011; FAO, 2013; NUERNBERG et al., 2005).

A pecuária bovina de corte, predominante no Brasil, baseada no uso de plantas forrageiras adaptadas às condições de clima e solo da região e na utilização limitada de insumos e presente no cenário econômico há muitos anos, tem sofrido acentuado desenvolvimento nas últimas décadas, através da expansão da fronteira agrícola, com a incorporação de novas terras, em sua maioria desprovida de infraestrutura e tendo desgaste do solo pelo sistema intensivo de produção de grãos. (CARVALHO, T. B. D.; ZEN, 2009). Porém, ela pode ser considerada como uma atividade possível de ser implantada e conduzida com relativo sucesso, sem que seja necessário o preparo mais cuidadoso da terra, ou o uso mais intensivo de insumos, de tecnologia e de mão de obra. Isto é, na pecuária é possível produzir, embora com baixa eficiência e talvez por conta disso, o país tem sofrido pressões ambientais e de mercado, para o aumento da disponibilidade de tecnologia (tecnologias de recuperação e manejo de pastagens, lançamento de cultivares mais produtivas de capins, melhoramento genético do rebanho e etc.) com incentivo a mudança de atitude para o setor produtivo de carne. (DIAS-FILHO, 2014). 
Com o intuito de fazer um bom manejo da pastagem e do pastejo, é realizado um trabalho no sentido de aumentar a área de pastagem (suprimento) para fornecer mais alimento a um mesmo rebanho, atendendo a demanda necessária. Esse processo pode ser caracterizado como a "fase primária" de expansão de pecuária em áreas de fronteira agrícola, no qual o aumento de produção é alcançado, sobretudo com a expansão útil das áreas de pastagem. (DIAS-FILHO, 2011).

Nos últimos anos têm se observado uma busca por uma produção bovina de maneira mais profissionalizada e verticalizada, com um movimento de incorporação de tecnologias ao setor, apoiada em alguns investimentos em formação, recuperação ou reforma de pastagens, mas, sobretudo, em investimentos na qualidade do rebanho e essa é chamada por DIAS-FILHO (2011) de "fase secundária". Nesse contexto, é possível destacar a avançada utilização de estudos de genética, que contribuíram para a identificação de características que produzem maior ganho de peso e redução no tempo de engorda do animal, e que ao mesmo tempo possibilitaram o cruzamento e posterior aclimatação ao país de raças diferenciadas, além do desenvolvimento de processos de inseminação artificial, resultando em maior produtividade a produção pecuária.

Os principais processos em sistemas de produção de alimento para pastagem são a utilização da energia luminosa e o suprimento de nutrientes para o crescimento da planta forrageira. Em sistemas de produção animal, dois outros estágios são de grande importância: (1) as plantas devem ser consumidas pelos animais e (2) convertida em produto animal. Cada um desses estágios tem sua própria eficiência e pode sofrer influência do manejo e contribuir para a eficiência do processo como um todo, que possui como essência o alcance do balanço efetivo entre as deficiências do processo produtivo: crescimento, utilização e conversão. (HODGSON, 1990).

Uma primeira parte do estágio 1 pode ser contemplada pela eficiência de crescimento de uma planta forrageira, que depende em grande parte do potencial genético e das condições do meio (recursos disponíveis), gerando uma produção líquida de matéria seca, que é função do crescimento da forragem nova e da morte e desaparecimento de forragem velha. (ANDRADE, R. P., 2001). 
A segunda parte do estágio 1 comporta o cuidado com a eficiência na utilização forragem, que pode ser definida como a proporção da forragem bruta acumulada e que é removida por animais em pastejo, antes de entrar em senescência (envelhecimento), ou seja, a métrica de eficiência de utilização corresponde à minimização das perdas de tecidos foliares por senescência. (MAZZANTI; LEMAIRE; GASTAL, 1994).

O estágio 2 é contemplado pela eficiência de conversão de nutrientes ingeridos em produto animal. Animais com alto potencial de produção possuem alta capacidade de ingestão de matéria seca e uma eficiência de conversão maior do que animais de menor potencial para uma mesma circunstância. Uma alta conversão significa alto consumo de matéria seca e baixa eficiência em utilização de forragem acumulada, que possui alto índice de perda de material por senescência e morte. (HODGSON, 1990).

Porém nenhum desses estágios será eficiente se não houver cuidados, que se iniciam com a escolha adequada da gramínea forrageira. No Brasil, existe um elevado número de opções de gramíneas para formação de pastagens, e seleção de espécie a serem cultivadas, que devem passar por critérios de topografia, drenagem do solo, pluviosidade da região, ocorrência de veranicos, ocorrência de pragas e doenças, nível de tecnologia exigida para manutenção, demanda de forragem a ser atendida, disponibilidade de sementes ou mudas, entre outros. (HODGSON, 1990).

Após diferentes análises técnicas de solo, é realizada a calagem, com o objetivo de neutralizar a acidez do solo e ao mesmo tempo fornecer cálcio $(\mathrm{Ca})$ e magnésio $(\mathrm{Mg})$, e fosfatagem, para fornecimento de fósforo $(\mathrm{P})$. A calagem se faz necessária devido à sensibilidade das gramíneas forrageiras à acidez do solo, a qual reduz a absorção de nutrientes de interesse e, consequentemente, o crescimento e a produção da pastagem. A fosfatagem, por sua vez, corrige a baixa disponibilidade de $\mathrm{P}$, característica da maioria dos solos brasileiros. Devido à baixa mobilidade desse nutriente no solo, opta-se pela realização do procedimento durante o processo de preparo da área para facilitar sua incorporação e melhorar a eficiência de uso do fertilizante. Nutrientes como nitrogênio $(\mathrm{N})$, potássio $(\mathrm{K})$ e, em menor escala, o enxofre (S) são, geralmente, fornecidos após o estabelecimento das pastagens e durantes os ciclos de crescimento, em adubação de cobertura. Esses nutrientes têm por característica importância essencial para a sobrevivência e produção da gramínea forrageira. Após a nutrição do solo, a disponibilidade do $\mathrm{N}$ é que irá determinar a produção de forragem, de forma que as respostas à adubação 
nitrogenada são expressivas em termos de produção de forragem. Isso ocorre porque o $\mathrm{N}$ é componente da clorofila, que é a enzima responsável pela fotossíntese e das proteínas, ou seja, está diretamente relacionado com o processo de produção de energia e fixação de $\mathrm{CO}_{2}$ pela planta forrageira. (TAIZ; ZEIGER, 2009).

\subsubsection{Adubação e Nutrição Nitrogenada}

Pecuaristas, de forma geral, consideram a adubação sob dois diferentes aspectos: cultural e técnico. No aspecto cultural, entendem que é uma ação inviável, visto que esse passa de geração para geração. No aspecto técnico, muitos deles obtiveram maus resultados, especialmente econômicos. Alguns estudos atribuem o mau resultado ao não ajuste no manejo do pastejo na medida de aplicação da adubação ou aplicação de técnicas e estratégias de adubação.(CASTAGNARA et al., 2011; MARTUSCELLO et al., 2006; MESQUITA; NERES, 2008; PACIULLO; GOMIDE; RIBEIRO, 1998).

A maior ou menor viabilidade econômica no processo de adubação é dependente do valor que foi gasto para sua realização, da quantidade de produto animal produzido e do valor com que a arroba do boi produzida foi comercializada. O preço de adubação e o valor da arroba do boi são dependentes de uma série de fatores que não são diretamente controlados pelo pecuarista, como por exemplo, a quantidade de adubo animal produzido. Porém, normalmente esse fator é produto da taxa de lotação e do desempenho dos animais no pasto. PARIS et al. (2009) notou maiores taxas de lotação e desempenhos por animal em pastos que receberam $200 \mathrm{~kg} \mathrm{~N} / \mathrm{ha}$, devido a maior proporção de folhas e maior valor nutritivo da forragem disponível. GIMENES et al. (2011) verificou aumentos de 20\% em desempenho animal e de 30\% nas taxas de lotação devido ao aumento na dosagem de $\mathrm{N}$ de 50 para $200 \mathrm{~kg} / \mathrm{ha} / \mathrm{ano}$. Dessa forma, é possível identificar benefícios pela adubação nitrogenada em conjunto com o manejo adequado da espécie forrageira adotada no pasto.(PACIULLO et al., 1998).

A nutrição nitrogenada afeta o crescimento natural das plantas forrageiras em diversos processos, como por exemplo na velocidade de aparecimento de folhas longas em vegetação por perfilho (individual). (CRUZ; BOVAL, 2000). Estudiosos (ALEXANDRINO et al., 2004; GASTAL; NELSON, 1994; PEREIRA et al., 2010) constaram um aumento de três a quatro vezes sobre a taxa de alongamento de folhas (TAIF) e lineares sobre a taxa de aparecimento de folhas (TApF) devido ao uso de adubação nitrogenada. Porém, devido ao ritmo de crescimento 
mais acelerado, estudos (ANDRADE, A. C. et al., 2005; MARTUSCELLO et al., 2006; MAZZANTI et al., 1994; PEREIRA, 2009) demonstraram que plantas adubadas com $\mathrm{N}$ (independente do método de pastejo adotado) atingem um número máximo de folhas por perfilho de forma precoce, o que resulta na diminuição na duração de vida das folhas, resultando em decréscimos na eficiência de utilização e produtividade do sistema de pastagem. Em contrapartida, para uma dada condição de ambiente favorável (regime pluviométrico e térmico adequados) o nitrogênio pode gerenciar o ritmo de crescimento das plantas forrageiras, aumentando a velocidade dos ciclos de renovação - folhas e perfilhos no pasto.(ALEXANDRINO et al., 2004; CASTAGNARA et al., 2011; FRICKE; MCDONALD; MATTSON-DJOS, 1997).

\subsubsection{Valor Nutritivo}

A composição química das partes da plantas forrageiras (lâminas foliares, bainhas, colmos e inflorescência) varia e o valor nutritivo depende de proporções de componentes morfológicos. Diferentes estudos demonstram modificações no valor nutritivo da forragem em pastagens adubadas. (CASTAGNARA et al., 2011; FREITAS et al., 2007; MESQUITA; NERES, 2008; PACIULLO et al., 1998; RIBEIRO; PEREIRA, 2010). PACIULLO et al. (1998) não identificou melhoria em digestibilidade com a adição de doses de nitrogênio em pastos de capim do tipo elefante, diferente de CASTAGNARA et al. (2011), que observou perda de proteínas e fibras e aumento de digestibilidade.

\subsubsection{Criação Bovina}

Para a Associação Nacional da Indústria de Carne Bovina dos Estados Unidos (do inglês "National Cattlemen's Beef Association" ou NCBA), sustentabilidade dentro da cadeia produtiva bovina pode ser definida como atender à crescente demanda por carne bovina, equilibrando a responsabilidade ambiental, oportunidade econômica e diligência social. Porém, mensurar esses desempenhos com precisão representa um desafio, uma vez que esta cadeia de fornecimento de carne é um dos sistemas alimentares mais complexos. (BEEFPOINT, 2016b). O ciclo de vida da carne bovina é iniciado na fase de cultivo de alimentos para o gado e essa produção segue contínua para a alimentação do animal vivo, desde o nascimento até sair do confinamento para o abatedouro. (BEEFPOINT, 2000). O fluxograma do ciclo de vida está indicado na figura 12 . 
Nos bastidores da produção, o sistema passou a ser analisado muito mais como tipo de atividade do que como tecnologia de processos. Em anos recentes, devido à incorporação de novas tecnologias que visam o aumento da produtividade, os sistemas intensivos de produção aumentaram em algumas regiões; são os chamados confinamentos ou semi-confinamentos. Com isso, a produção pecuária bovina de corte tem sido estratificada em diferentes etapas, mas de forma geral envolve: cria, recria e engorda. (BARCELLOS, J. O. J.; SUÑE; SEMMELMANN, 2004).

Figura 12: Fluxograma de Etapas na Produção Pecuária Bovina

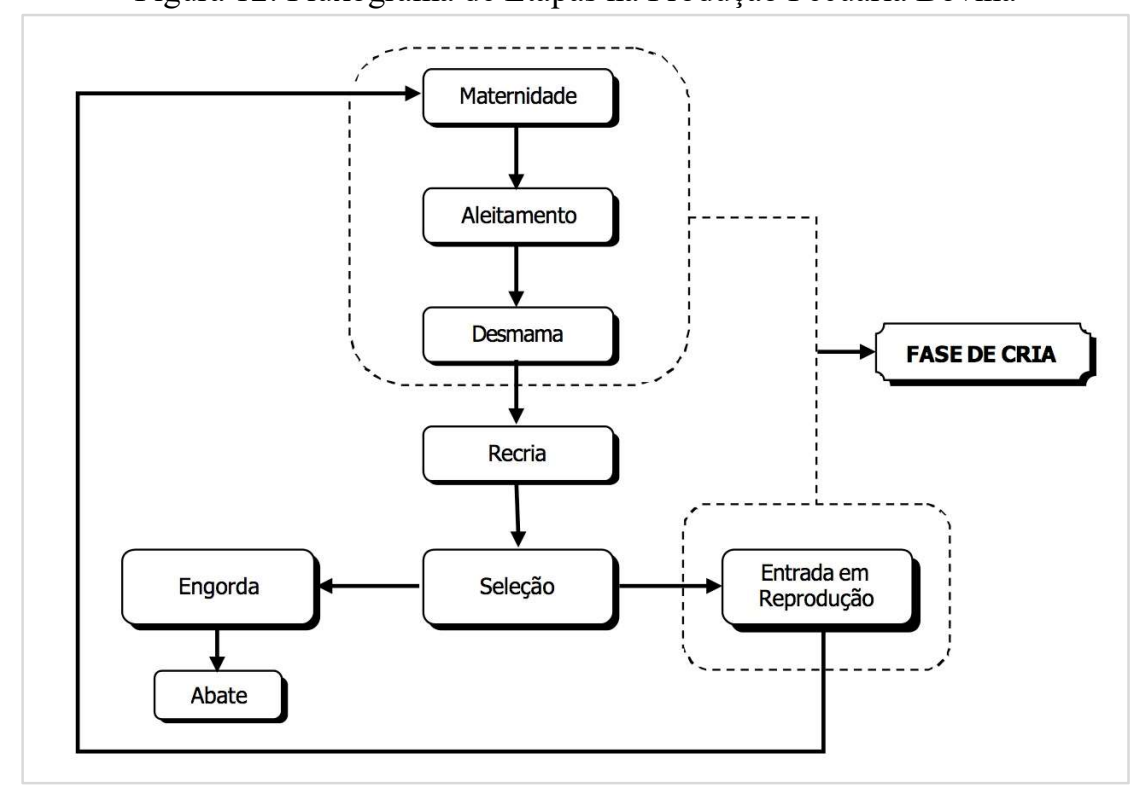

Fonte: OLIVEIRA et al. (2006)

\subsubsection{Fase de Cria}

A fase de cria na bovinocultura de corte corresponde não só aos bezerros e bezerras criados na propriedade, mas também às matrizes (envolvendo vacas em reprodução e novilhas aptas à cobertura) e os reprodutores. (CARVALHO, T. B. D.; ZEN, 2009).

No passado, a tecnologia de processos gerenciava o sistema de produção, com a premissa de que o melhor caminho para aumentar a rentabilidade do sistema era o aumento de produtividade. Devido à eficiência alimentar ser maior nos animais jovens, essas melhorias foram destinadas a estas categorias para acasalar mais cedo ou abater em idades menores. A consequência disso foi o aumento do número de bezerros nascidos, crescimento do efetivo e diminuição do peso de abate (animais mais jovens e menores), o que levou a ganhos em uma etapa e perda em outra, pois o valor econômico obtido pelo novilho passou a ser pouco 
expressivo dentro do sistema. Dessa forma o aumento na escala não compensava, na maioria das vezes, a queda no valor individual do novilho mais leve. Além disso, os frigoríficos desejavam e continuam exibindo novilhos mais pesados. (CARVALHO, T. B. D.; ZEN, 2009).

Segundo OLIVEIRA et al. (2006), há uma diversidade considerável de sistemas de produção, e mesmo nas regiões de pecuária mais evoluída as práticas não são idênticas. $O$ conceito de produção intensificada ou sistema tecnificado consiste em práticas capazes de explorar com a máxima eficiência os recursos existentes, objetivando tornar a exploração mais competitiva com outras atividades agrícolas e de certa forma, mais econômica. Quando a utilização de pastos tem elevado grau de importância para o sistema de produção, é considerado o conceito de produção de carne por unidade de área ( $\mathrm{kg}$ de $\mathrm{PV} / \mathrm{ha}$ ou $\mathrm{kg}$ de carcaça/ha), produção de bezerros por unidade de área e também mensurações individuais (GMD/dia), o que caracteriza a eficiência das glebas destinadas à produção de alimento para o rebanho. (CORSI, 1985; OLIVEIRA et al., 2006).

A cria é considerada como baixa eficiência por unidade de área, pois para a produção do bezerro são necessárias outras categorias animais. (CORRÊA, 1996). A estrutura mínima para produção bovina está indicada na tabela 10 .

Tabela 10: Estrutura mínima de um rebanho de cria para produção

\begin{tabular}{lccc} 
Categoria Animal & ${\text { Quantidade }(\mathbf{c a b})^{\mathbf{1}}}$ & Peso (Kg) & Total de Kg \\
\hline Vaca & 1,00 & 450 & 450 \\
Novilha de 1 ano & 0,20 & 200 & 40 \\
Novilha de 2 anos & 0,20 & 300 & 60 \\
Vaca descarte & 0,20 & 470 & 94 \\
Touro & 0,04 & 600 & 24 \\
Bezerro & 0,80 & 60 & 48 \\
\hline Total & 2,44 & - & 716 \\
${ }^{1}$ Rebanho de cria com idade de acasalamento aos 2 anos, renovação de matrizes \\
na ordem de 20\% e taxa de nascimentos de 80\%. Uso de touros na proporção de \\
1:25.
\end{tabular}

Fonte: (BARCELLOS, J. O. J. et al., 2004)

Essa é uma unidade do núcleo de cria, cuja área necessária situa-se em torno de 2 hectares. Para um rebanho formado por 1.000 matrizes seriam necessários 2.000 hectares. O rendimento em proporção nesse módulo está indicado na figura 13. 
Figura 13: Rendimento em Proporção de Rebanho de Cria

ㅁ produção de bezerros $=400 \times 160 \mathrm{~kg}=64.000 \mathrm{~kg}$

口 produção de bezerras $=200 \times 160 \mathrm{~kg}=32.000 \mathrm{~kg}$ (200 sobram para reposição)

口 produção de vacas de descarte $=200 \times 470 \mathrm{~kg}=94.000 \mathrm{~kg}$

व total produzido $=190.000 \mathrm{~kg}$, ou seja $95 \mathrm{~kg}$ de peso vivo/hectare.

Fonte: (BARCELLOS, J. O. J. et al., 2004)

Nessa análise a cria projetada é de média para alta produtividade e seu rendimento é bruto. Quando se acrescenta o custo de produção, o capital estocado em animais e a demanda intelectual, a situação fica mais desvantajosa para a pecuária de corte. Portanto, é compreensível que produtores menos capitalizados e mais pessimistas mudem a forma de exploração de suas propriedades. (BARCELLOS, J. O. J. et al., 2004; CORRÊA, 1996).

Essa baixa eficiência sempre foi conhecida por técnicos e produtores, mas pelo dinheiro fácil de outrora e pela busca de altos índices de produtividade, muitos recursos e investimentos na melhoria dos campos - pastagens cultivadas, fertilização do solo e até suplementação - foram empregados intensivamente. No entanto, a nova ordem econômica, agora num momento de parcos recursos, exige uma mudança de atitudes. Portanto, será necessário produzir muitos quilogramas de bezerro por vaca ao ano, na maioria dos sistemas e produção, agora alicerçada nas limitações ambientais e na capacidade de gerir os recursos intelectuais e financeiros da propriedade rural. (CORRÊA, 1996).

Neste contexto, os processos tecnológicos relacionados ao manejo tornam-se as ferramentas mais importantes para, a um baixo custo, gerar altas produtividades na cria. Assim, o ajuste da temporada de acasalamento, a manipulação do escore da condição corporal, o desmame antecipado e a busca de genótipos mais adaptados e longevos serão práticas rotineiras neste novo cenário. Não será permitido à vaca utilizar pastagens cultivadas. Como tecnologia complementar, a suplementação mineral, específica para a vaca de cria, terá papel fundamental para a manutenção da eficiência reprodutiva nestes novos campos. Serão necessárias novas formulações minerais, com outros níveis de fósforo $(+80 \mathrm{~g} / \mathrm{kg})$, selênio, zinco, enxofre e manganês, capazes de assegurar à vaca de cria todos os seus desafios no novo ambiente. Fontes 
de boa qualidade e garantia de consumo da mistura mineral também serão aspectos preponderantes no programa de suplementação mineral. (CORRÊA, 1996).

Dentro do sistema de produção Cria, um produto chama especial atenção, que é a vaca de descarte. Ele é o produto principal, ao contrário do bezerro. Além disso, representa grande amplitude no seu potencial de acumular peso. Talvez esse seja um dos caminhos rápidos e eficientes para aumentar a produtividade do sistema através do aumento do peso de abate.

Figura 14: Eficiência das vacas de descarte no sistema de cria

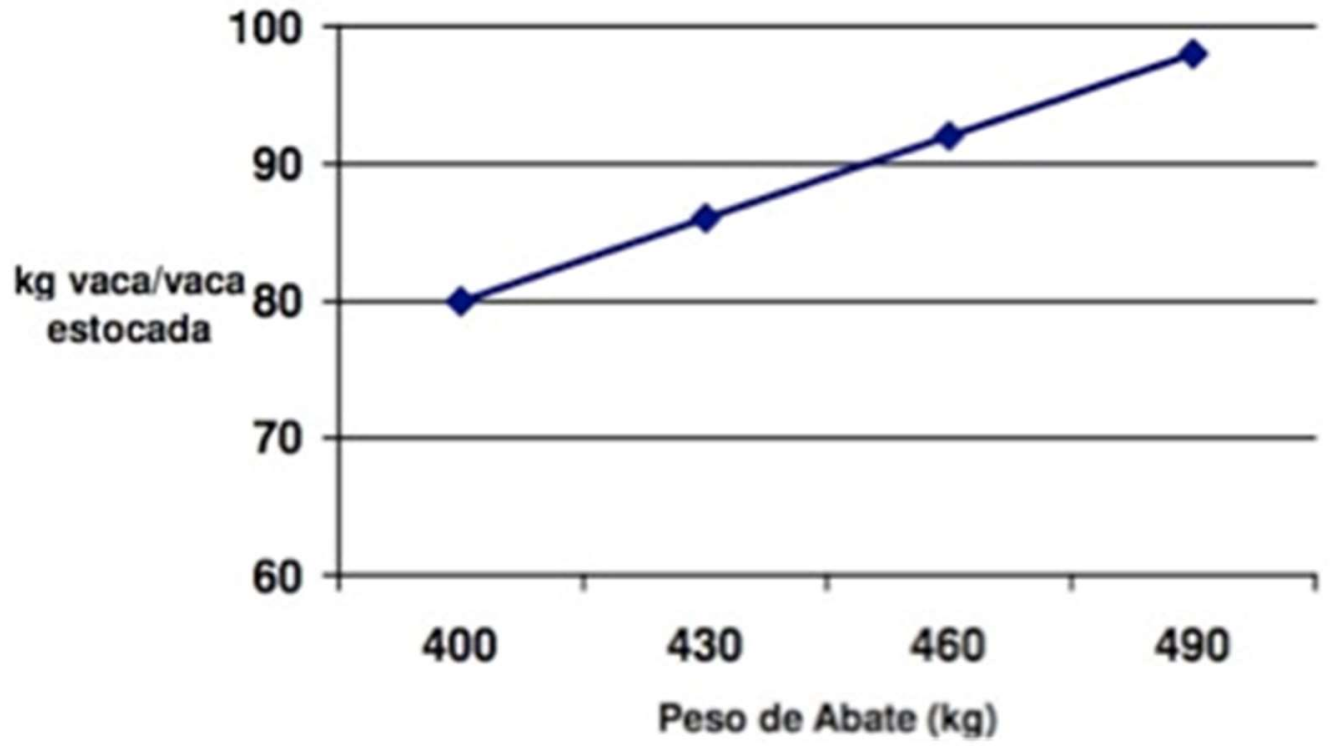

Fonte: (BARCELLOS, J. O. J. et al., 2004)

O aumento do peso de abate segue princípios da curva de crescimento (indicados na figura 14) e permite que as vacas depositem uma grande quantidade de carne a baixo custo. Cada vaca descartada pode produzir, a partir do desmame do último bezerro até o abate, próximo de $100 \mathrm{~kg} / \mathrm{vaca}$ estocada no sistema. Essa categoria animal com certeza será a que melhor aproveitará o sistema onde o produtor libera áreas para agricultura, pois tem a capacidade de aproveitar eficientemente as restevas de lavoura de baixa qualidade, o que não poderia ser aproveitada por outros componentes da cria. (CSR/UFMG, 2015).

A produção de carne na Amazônia tem historicamente crescido (conforme figura 15) graças à expansão de pastagens, mas esse quadro começa a mudar com a intensificação dos sistemas de pecuária induzida, tanto pela pressão do mercado e exigências ambientais, como pelo maior controle do desmatamento na Amazônia. O resultado desta situação é uma diminuição dos 
rebanhos de cria, com forte abate de fêmeas e o deslocamento da cria para zonas sem qualquer potencial agrícola, as chamadas zonas marginais. (CSR/UFMG, 2015).

Figura 15: Evolução da unidade animal por hectare nos estados da Amazônia - 1987/2013

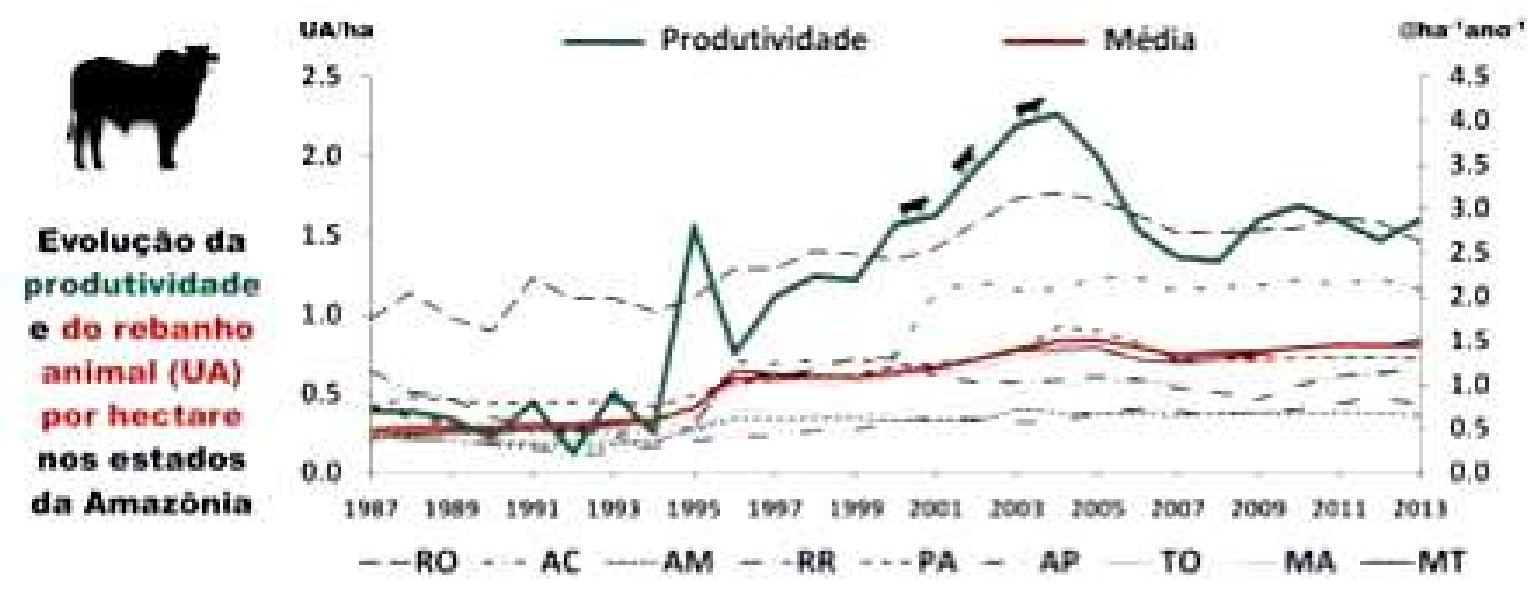

Fonte: (CSR/UFMG, 2015)

Segundo OLIVEIRA et al. (2006), o objetivo dos criadores bovinos é que os recursos financeiros investidos sejam eficientes para aplicar tecnologias que otimizem o desmame de um bezerro pesado e saudável por ano, de cada vaca do rebanho, e que incluam:

a) A escolha dos grupos genéticos (matrizes e reprodutores para monta a campo ou com utilização das biotécnicas reprodutivas) que farão parte do planejamento genético do rebanho;

b) O manejo adequado, principalmente do ponto de vista nutricional e bioclimatológico dos touros, quando em monta no campo;

c) O manejo nutricional das matrizes (ou doadoras e receptoras, quando o caso) na estação de monta de no pré e pós-parto;

d) $\mathrm{O}$ manejo das pastagens e o planejamento alimentar das diferentes categorias envolvidas;

e) A execução dos métodos de aleitamento e formas de desmame;

f) A utilização de métodos de suplementação para os bezerros, tais como o uso de cocho privativo ("creep feeding") ou pasto privativo ("creep grazing");

g) O manejo e a escrituração zootécnica de maneira a ter o controle total do sistema produtivo e dos custos envolvidos na produção de modo a administrar os recursos e estimar lucros, bem como realizar a meta-avaliação do processo administrativo. 
São avaliados diferentes índices zootécnicos para analisar a produtividade da criação de gado de corte (indicados na tabela 11).

Tabela 11: Índices Zootécnicos de Produtividade da Pecuária de Corte

\begin{tabular}{lcc} 
Parâmetro & Média Brasileira & Sistema Tecnificado \\
\hline Taxa de natalidade (\%) & 60 & 80 \\
Taxa de mortalidade até a desmama (\%) & 8 & 4 \\
Taxa de desmama (\%) & 55 & 76 \\
Taxa de mortalidade pós desmama (\%) & 4 & 2 \\
Idade do primeiro parto (meses) & 48 & $24-36$ \\
Intervalo entre partos (meses) & 21 & 14 \\
Idade de abate (meses) & 48 & 30 \\
Taxa de abate (\%) & 21 & 33 \\
Peso da Carcaça (kg) & 200 & 230 \\
Lotação animal/ha & 0,9 & 1,6 \\
Kg de carcaça/ha & 34 & 80 \\
\hline
\end{tabular}

Fonte: BEEFPOINT (2000)

A taxa de mortalidade de animais, tanto em pré como em pós-desmame são bastante elevadas se comparadas com os valores aceitáveis de 4 e $2 \%$, respectivamente observados em sistemas eficientes de pasto (sistema tecnificado). (BEEFPOINT, 2000).

Da mesma maneira que se preconiza uma alta taxa de natalidade, busca-se maximizá-la de tal modo que as perdas de animais sejam mínimas, e para que o retorno dos investimentos efetuados em prol desses animais (alimentação e sanidade) seja maximizado. Para BEEFPOINT (2000), quanto maior a taxa de natalidade, maior o número de bezerros produzidos em relação ao número de matrizes da propriedade, indicando que um menor número de fêmeas é necessário para gerar uma mesma população de bezerros, ou ainda, uma área menor seria necessária para a produção de um mesmo número de bezerros. Assim, cada vaca do rebanho deveria produzir 1 bezerro por ano, em um intervalo entre partos de 13 a 14 meses, desmamar entre 0,83 e 0,90 bezerro por ano e, ao longo de sua vida útil, gerar oito crias, sendo descartada com aproximadamente 135 meses (11 anos). 
Um dos índices também considerados durante a fase de cria é o intervalo de partos (IP). O IP tende a superestimar a eficiência reprodutiva de um rebanho, por apenas considerar vacas que tiveram pelo menos dois partos, eliminando fêmeas que nunca reproduziram ou que tiveram apenas um parto. Em bovinos, o período ideal é um intervalo médio de parto de doze meses. Isso levaria a produção de um bezerro por vaca/ano. No entanto, a prática brasileira da bovinocultura de corte considera esse prazo mais longo do que o desejável e isso leva em muitas situações, ao comprometimento do desempenho geral do rebanho. Segundo BEEFPOINT (2000), a taxa média de natalidade do rebanho brasileiro está ao redor de $60 \%$, ou seja, por ano, nascem 60 bezerros para cada 100 fêmeas do rebanho. É como se um pecuarista fosse proprietário de um hotel com 100 hóspedes, mas somente 60 pagassem sua estadia ou, analisando de outra forma, cerca de $40 \%$ das fêmeas do rebanho nacional não produz um bezerro por ano e, portanto não cumprem sua principal função.

Um dos índices mais criticados na pecuária nacional é a idade para o abate, que atualmente aplica-se a de 48 meses. Considerando-se que o peso de abate dos animais machos varia ao redor de $450 \mathrm{~kg}$ de peso vivo ou 15 arroba, conclui-se que o ganho de peso médio diário do rebanho nacional é menor do que $290 \mathrm{~g} / \mathrm{dia}$ ao longo do ano, valor esse muito abaixo do potencial genético dos animais. Nesse sentido, se o ganho de peso médio diário fosse aumentado para 400 ou $600 \mathrm{~g} / \mathrm{dia}$, a idade de abate dos animais seria respectivamente de 3 e 2 anos. (BEEFPOINT, 2000).

Outro índice considerado é o rendimento de carcaça, que atualmente na pecuária brasileira é tido como satisfatório, sendo que os incrementos pouco expressivos podem ser obtidos através do uso de raças especializadas na produção de carne. Valores entre 55 e 59\% são satisfatórios, até porque aqueles acima de $60 \%$ são difíceis de serem concebidos na prática. (BEEFPOINT, 2000).

\subsubsection{Fase de Recria e Engorda}

A recria e a engorda, frente à expansão da agricultura, são etapas do processo que tem maior flexibilidade em tecnologia de processos e maior competitividade sobre o custo de oportunidade da terra do que a cria. Portanto, o impacto do reordenamento do uso do solo produz menores efeitos sobre estas atividades. Porém, os processos que demandam tecnologias mais intensivas, como a inclusão de suplementos, pastagens cultivadas ou grãos produzidos dentro do próprio 
sistema, começam a aproximar-se de rendimentos marginais cada vez menores e em muitos casos poderão inviabilizar o sistema. Todas essas tecnologias terão mais um caráter de oportunidade de negócio do que constituintes primários do sistema de produção destinado a recria ou engorda. (OLIVEIRA et al., 2006).

A necessidade de aumentar o peso do abate obrigatoriamente passará pela elevação de 2 a 3 meses na idade de engorda. Para isto será necessário uma recria e uma engorda a partir de genótipos de frame moderado, com uma curva de crescimento um pouco mais avançada do que a novilhos atuais. Assim, a deposição de gordura, conforme a exigência do mercado, ocorrerá sobre pesos mais elevados e não precocemente como o observado atualmente. Esse será com certeza um sistema mais sustentável e com menor custo. O primeiro inverno da recria será decisivo para estes objetivos e a tecnologia necessária é da década de 70. Portanto, assim como ocorreu um importante aprendizado durante o processo de intensificação da pecuária de corte e agora a exigência é desintensificar para sobreviver, aquelas tecnologias que tinham sido superadas voltam ao rol dos sistemas produtivos locais. (OLIVEIRA et al., 2006).

Com exceção dos aspectos relacionados aos problemas estruturais do setor e mesmo com uma nova conjuntura na pecuária, caracterizada por baixos preços do produto final e por uma pressão da agricultura, a engorda como negócio, tem apresentado os melhores resultados dos últimos anos, simplesmente por uma transferência de renda entre os elos dentro da porteira. A relação de troca boi: bezerro ou boi gordo: boi magro tem sido uma das melhores da última década. A pecuária de corte empobreceu, mas o terminador vem ganhando muito dinheiro, simplesmente porque sua matéria prima tem estado muito barata. Sua eficiência tem sido maior devido ao baixo custo do que a sua produtividade em quilogramas adicionados no sistema. Historicamente tem sido assim. Preços ou crise na bovinocultura de corte impacta a base de produção. Por outro lado as diferenças entre os elos se alargam. (CORRÊA, 1996; OLIVEIRA et al., 2006).

$\mathrm{Na}$ engorda e na recria deverá ocorrer uma discussão importante: inovação tecnológica ou inovação de processos. Ou seja, mudar o tipo de novilho produzido (Inovação Tecnológica) ou desenvolver novos processos de produção (Tipo de Engorda). Talvez seja necessário que ambas as atitudes devam ser implementadas. Com certeza o novilho atual não é o que o mercado deseja e os processos de criação não são os que garantem a renda ao produtor. Provavelmente o novo produto será um novilho com idade entre 24-36 meses, com 480-530 kg de peso, com 3-6 mm de gordura, cujos processos para produção são muito mais diversificados do que num sistema mais intensivo de animais jovens. (CORRÊA, 1996; OLIVEIRA et al., 2006). 
O rebanho brasileiro vem crescendo ao longo dos anos, mas a proporção de bois de 3 a 4 anos de idade e acima de 4 continua estável, embora se note uma redução da idade de abate, conforme explicitado na tabela 12 .

Tabela 12: Rebanho Bovino - por categoria animal (Milhões de animais)

$\begin{array}{lllllllll}2005 & 2006 & 2007 & 2008 & 2009 & 2010 & 2011 & 2012 & 2013\end{array}$

\begin{tabular}{llllllllll}
\hline Touros & 2,73 & 2,72 & 2,63 & 2,62 & 2,58 & 2,56 & 2,51 & 2,37 & 2,30 \\
Vacas & 72,9 & 69,5 & 66,3 & 68,9 & 70,8 & 71,6 & 72,4 & 70,2 & 69,2 \\
Novilhas 2 a 3 anos & 15,5 & 14,9 & 15,7 & 15,9 & 15,1 & 15,0 & 15,4 & 15,1 & 16,0 \\
Novilhas 1 a 2 anos & 24,2 & 25,5 & 25,2 & 24,1 & 24,1 & 25,2 & 25,5 & 25,6 & 25,9 \\
Bezerras & 28,4 & 28,7 & 26,7 & 28,2 & 28,6 & 29,6 & 30,3 & 29,9 & 28,9 \\
Bezerros & 28,2 & 28,5 & 26,6 & 28,0 & 28,5 & 29,5 & 30,0 & 29,9 & 29,0 \\
Novilhos 1 a 2 anos & 20,1 & 21,3 & 21,3 & 20,3 & 20,4 & 21,2 & 21,9 & 22,0 & 22,1 \\
Novilhos 2 a 3 anos & 10,9 & 10,8 & 11,5 & 12,0 & 11,3 & 11,1 & 12,3 & 12,3 & 12,7 \\
Bois 3 a 4 anos & 3,44 & 3,22 & 3,44 & 3,96 & 4,10 & 3,78 & 4,10 & 4,28 & 3,99 \\
Bois acima de 4 anos & 0,69 & 0,59 & 0,65 & 0,82 & 0,96 & 0,97 & 1,14 & 1,37 & 1,26 \\
\hline TOTAL & 207 & 206 & 200 & 205 & 206 & 211 & 216 & 213 & 211
\end{tabular}

Fonte: (CSR/UFMG, 2015)

\subsubsection{Insumos para produção de alimentos pecuaristas}

Com o crescimento populacional relativamente alto esperado até 2030 , é previsto que a demanda por alimentos (entre eles carne) e água tenha aumento. De acordo com BARLOW; CLARKE (2003) há uma estimativa de que em um horizonte de 25 anos, até $2 / 3$ da população estará vivendo com severa escassez de água doce. BROWN, L.; FLAVIN; FRENCH (2000) afirma que, o mundo ao se defrontar com a escassez de água também enfrentará a escassez de alimentos, uma vez que são necessárias, em média, 1000 toneladas de água para produzir uma tonelada de grãos, ou seja, uma relação 1000:1. Portanto a competição pela água provavelmente afetará os mercados mundiais de alimentos.

Em muitos países, a disponibilidade de água para a agricultura já é limitada e incerta, e esperase que essa situação piore ainda mais. A exploração de água para a agricultura corresponde a 44\% do total da água extraída nos países da Organização de Cooperação e de Desenvolvimento Econômico - OCDE, mas equivale a mais de $60 \%$ nos casos de oito países OCDE que dependem fortemente da agricultura irrigada. Nos BRICs (Brasil, Federação Russa, Índia e China), a agricultura é responsável por $74 \%$ da exploração de água (oscilando entre $20 \%$, no caso da 
Federação Russa, e 87\%, no caso da Índia). Nos países menos desenvolvidos (LDCs, na sigla em inglês), a proporção é de mais de 90\%. (HOEKSTRA; MEKONNEN, 2012 p.3236).

Como já abordado, a poluição por contribuição de áreas agrícolas é do tipo difusa e por meio dela podem ser originados problemas sérios. Um exemplo disso é a entrada de fertilizantes, principalmente dos nitrogenados e fosfatados. Segundo GOELLNER (2004), dependendo do manejo do solo, problemas sérios de eutroficação com produção de fitoplanctoxinas que afetam toda a vida aquática e também são extremamente tóxicas ao homem podem ser ocasionados. Também podem ocorrer a geração, no próprio corpo da água, de outros contaminantes como as nitrosaminas e trihalometanos carcinogênicos ao homem. Águas com elevados teores de nitritos e nitratos podem ocasionar, principalmente em neonatais, intoxicações denominadas de metemoglobinemia que podem, em alguns casos, ser fatais.(GOELLNER, 2004 p.5-6).

A irrigação constitui apenas uma pequena parte do consumo agrícola de água, mas é responsável por mais de $40 \%$ da produção mundial, participando em menos de $20 \%$ das terras cultivadas. Globalmente, a produtividade das lavouras irrigadas é 2,7 vezes maior do que a da produção abastecida somente pela água das chuvas e, por isso, a irrigação continuará desempenhando um importante papel na produção de alimentos. A área equipada para a irrigação aumentou de 170 milhões de hectares, em 1970, para 304 milhões de hectares, em 2008. Ainda existe um potencial de expansão, em particular na África Subsaariana e na América do Sul, em lugares onde existe água suficiente disponível. (HOEKSTRA; MEKONNEN, 2012 p.3236).

As preocupações com a insegurança alimentar estão aumentando ao redor do mundo, e mais água será necessária para atender às crescentes demandas por alimentos e energia (biocombustíveis). A exploração de água para a agricultura tende a diminuir com o aumento nos níveis de desenvolvimento. (HOEKSTRA; MEKONNEN, 2012 p.3236).

Um indicador de consumo de água que pode confirmar o uso anteriormente comentado é o Water Footprint Network ou conhecido como "Pegada Hídrica - PH”. Ele analisa o consumo de água de forma direta e indireta, tanto do consumidor quanto do produtor. A Pegada Hídrica de um indivíduo, comunidade ou empresa é definida como o volume total de água doce que é utilizado para produzir os bens e serviços consumidos pelo indivíduo, comunidade ou produzidos pelas empresas. (FAO, 2013 p.148). 
Ao se analisar a PH de países, identifica-se a China, Índia e Estados Unidos com os maiores índices totais (figura 16), com PHs totais de 1.207; 1.182; e $1.053 \mathrm{~m} 3 /$ ano, respectivamente. Cerca de $38 \%$ do $\mathrm{PH}$ da produção mundial encontra-se dentro desses três países. O próximo país no ranking é o Brasil, com total de $\mathrm{PH}$ no seu território de $482 \mathrm{~m} 3 /$ ano. A Índia é o país com o maior PH azul no seu território: 243 m3/ano, que é de 24\% do azul PH global. Irrigação do trigo é o processo que leva a maior parcela (33\%) em no PH azul da Índia, seguido de irrigação de arroz (24\%) e de irrigação de cana de açúcar (16\%). A China é o país com o maior PH cinza dentro de suas fronteiras: 360 m3/ano, que é 26\% do cinza PH global.

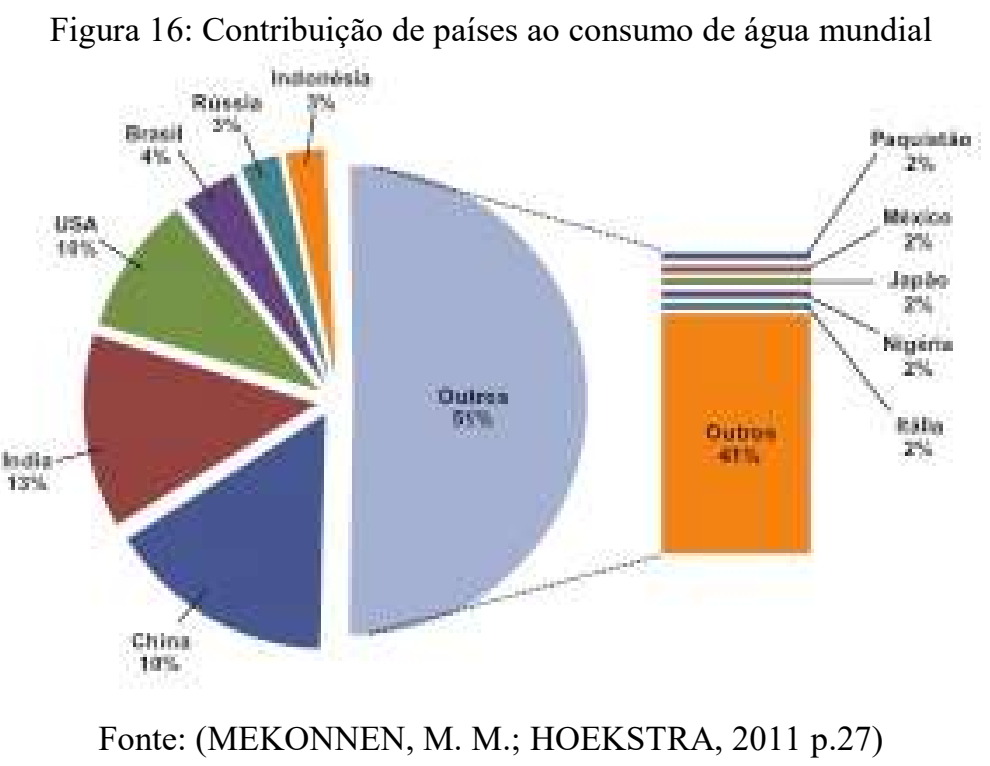

Em todos os países, a PH relacionada com a produção agrícola tem a maior participação na $\mathrm{PH}$ total dentro do país (demonstrado na figura 17). China e os Estados Unidos têm as maiores PHs em seu território relacionadas com a produção industrial; 22\% da PH global em relação à produção industrial se encontra na China e 18\% nos Estados Unidos. Bélgica é o país em que a produção industrial tem a maior participação na $\mathrm{PH}$ total no país. A PH de indústrias na Bélgica contribui $41 \%$ para a PH total do país; produção agrícola ainda contribui 53\%. (HOEKSTRA; MEKONNEN, 2012 p.3232).

Segundo WFN (2005), a PH média global anual relacionada com a produção agrícola e industrial e de abastecimento de água doméstica para o período 1996-2005 foi de $9.087 \mathrm{~m} 3 /$ ano 
(74\% verde, azul 11\%, 15\% de cinza)*. A produção agrícola leva a maior fatia, representando $92 \%$ do PH global. A contribuição da produção industrial é de $4,4 \%$ da PH total e abastecimento doméstico de água de 3,6\%. (HOEKSTRA; MEKONNEN, 2012 p.3233).

Figura 17: Consumo de água na produção industrial de alimentos

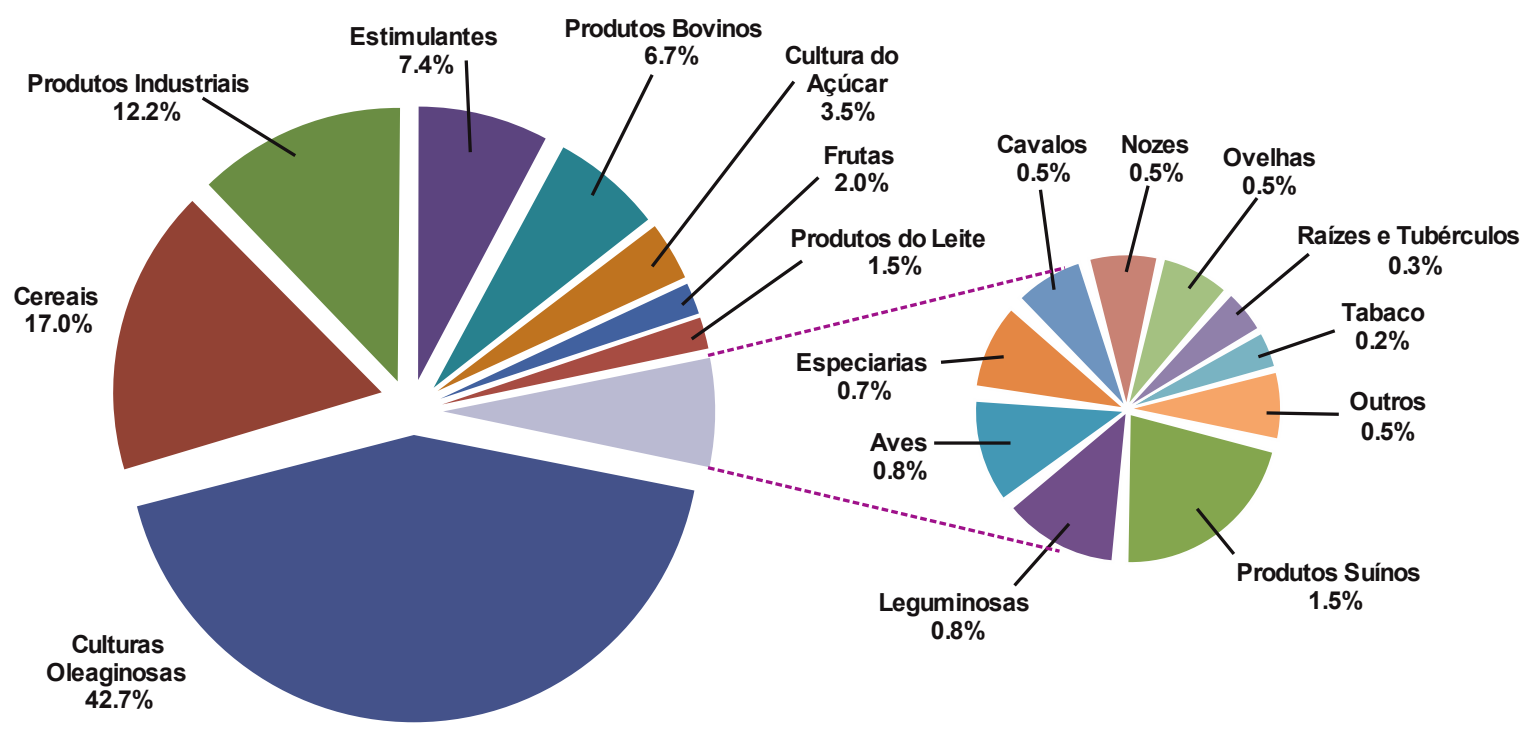

Fonte: (MEKONNEN, M. M.; HOEKSTRA, 2011 p.22)

A PH mundial relacionada com a produção de bens para exportação é 1; 762 m3/ano. No setor agrícola, 19\% da $\mathrm{PH}$ total refere-se à produção para exportação; no setor industrial esta é de 41\%. A PH relacionada ao abastecimento de água doméstica não diz respeito a exportar em tudo. Tomado como uma média dos três setores que utilizam água, descobriu-se que $19 \%$ da PH global não é para consumo interno, mas para exportação. (HOEKSTRA; MEKONNEN, 2012 p.3233).

A PH média global anual relacionada ao consumo foi de $1.385 \mathrm{~m} 3 /$ ano per capita ao longo do período 1996-2005. O consumo de produtos agrícolas determina em grande parte o PH mundial relacionada com o consumo, contribuindo para 92\% da $\mathrm{PH}$ total. O consumo de produtos industriais e de uso doméstico de água contribuem 4,7\% e 3,8\%, respectivamente. Quando olhamos para o nível de categorias de produtos, o consumo de cereais contribui com a maior participação para a PH global (27\%), seguido por carnes $(22 \%)$ e produtos lácteos $(7 \%)$. (HOEKSTRA; MEKONNEN, 2012 p.3233).

\footnotetext{
* Verde (Água armazenada no solo ou temporariamente no topo do solo ou vegetação); Azul (Águas superficiais e subterrâneas); Cinza (Água doce necessária para assimilar a carga de poluentes).
} 
O ranking entre países indica que os industrializados têm PHs per capita na faixa de 1.250$2.850 \mathrm{~m} 3 /$ ano. O Reino Unido, com uma PH de $1.258 \mathrm{~m} 3 /$ ano, é na parte inferior dessa faixa, enquanto que os Estados Unidos, com uma pegada de $2.842 \mathrm{~m} 3 /$ ano, está na parte alta. As diferenças podem ser parcialmente explicadas por diferenças no padrão de consumo. Nos Estados Unidos, por exemplo, o consumo médio de carne bovina - um dos grandes consumidores de água - foi de $43 \mathrm{~kg} /$ ano per capita, cerca de 4,5 vezes a média global, enquanto que no Reino Unido, a média foi de $18 \mathrm{~kg} /$ ano per capita, cerca de duas vezes a média global. Outro fator por trás das diferenças na PHs é o consumo de água e poluição por unidade de produto por país. (HOEKSTRA; MEKONNEN, 2012 p.3234).

A PH per capita nos países em desenvolvimento varia muito mais do que em países industrializados. Há valores em um intervalo 550-3.800 m3/ano per capita. Na extremidade baixa é a República Democrática (DR) do Congo, com 552 m3/ano per capita. Na parte alta, encontra-se a Bolívia (3.468 m3/ano per capita), Níger (3.519 m3/ano per capita), e Mongólia (3.775 m3/ano per capita). As explicações para esses números podem ser identificadas pela diferença nos padrões de consumo e na diferença nas PHs dos produtos consumidos na outra mão. Na faixa de relativamente grandes PHs per capita, há ambos os países industrializados e em desenvolvimento. Estes últimos encontram-se nesse intervalo geralmente não por causa de seu grande relativo consumo, (embora haja um grande consumo relativo de carne que pode desempenhar esse papel), mas por causa de suas produtividades especialmente baixas de água e grandes PHs por tonelada de produto consumido. Na Bolívia, por exemplo, o consumo de carne é de 1,3 vezes a média global, mas a PH por tonelada de carne é de cinco vezes a média global. Para o Níger, o consumo de cereais per capita é 1,4 vezes superior à média global, mas a PH de cereais por tonelada é de seis vezes a média mundial. (HOEKSTRA; MEKONNEN, 2012 p.3234).

A PH azul per capita, dos países do Norte da África Central e Sudoeste da Ásia aparecem no topo. Os consumidores no Turquemenistão têm a maior PH azul de todos os países, ou seja, 740 m3/ano per capita em média. Outros países com uma grande PH azul são (em ordem decrescente): Irã (589), Emirados Árabes Unidos (571), Egito (527), Líbia (511), Tajiquistão (474), Arábia Saudita (447), e Paquistão (422 m3/ano per capita). A média da PH azul global de consumo é de 153 m3/ano per capita, que é de 11 \%do total PH. A variação na PH azul per capita entre os países é grande, muito maior do que a variação no total de $\mathrm{PH}$ per capita. 
Considerando que a maior PH total per capita (Mongólia) é cerca de sete vezes o menor total de $\mathrm{PH}$ per capita (RD Congo), a diferença no caso da $\mathrm{PH}$ azul é mais do que um fator de cem. (HOEKSTRA; MEKONNEN, 2012 p.3234).

O estudo mostra que cerca de um quinto da PH global no período de 1996-2005 não foi resultado apenas do consumo interno, mas também para exportação. O volume relativamente grande dos fluxos de água virtual internacionais e as dependências de água externos associados reforçam o argumento para colocar a questão da escassez de água num contexto global. (HOEKSTRA; MEKONNEN, 2012 p.3234).

A PH média global relacionada com o consumo é $1.385 \mathrm{~m} 3 /$ ano per capita ao longo do período 1996-2005. Os países industrializados têm PHs na faixa de 1.250-2.850 m3/ano per capita, enquanto os países em desenvolvimento mostram uma gama muito maior de 550-800 m3/ano per capita. Dois fatores determinam a magnitude da PH do consumo nacional: (i) o volume e o padrão de consumo e (ii) a $\mathrm{PH}$ por tonelada de produtos consumidos. Este último, no caso de produtos agrícolas, depende de fatores como clima, irrigação, adubação e prática e rendimento da cultura. Os pequenos valores de $\mathrm{PH}$ para países em desenvolvimento dizem respeito a volumes de baixo consumo. (HOEKSTRA; MEKONNEN, 2012 p.3236).

O aumento estimado global da população mundial vai levar a um aumento significativo na demanda de alimentação e ocupação de terras. A combinação desses processos gerou o interesse internacional para o tema de segurança alimentar global. Os principais fatores que influenciam a segurança alimentar mundial são o encolhimento de terras agrícolas, a redução da pesca, o aumento da riqueza em países como China e Índia, com consequente aumento da demanda por alimentos, aquecimento global e uma intensificação global da agricultura e maiores pressões sobre os solos. (GARDI et al., 2014 p.900).

A produção de biocombustíveis também representa uma grande preocupação no que diz respeito à disponibilidade de terras para a produção de colheitas. Há alguns cenários desenvolvidos pela Agência Internacional de Energia para o uso da terra (IEA) que estimam que cerca de $5 \%$ da área cultivada da UE teria que ser convertida para a produção de biocombustíveis, a fim de substituir 5\% do seu abastecimento de gasolina, enquanto que 15\% de sua área cultivada teria que ser convertida para substituir 5\% do abastecimento de gasóleo. (ESCOBAR et al., 2009). 
A queda contínua das terras aráveis per capita é frequentemente citada como um indicador de problemas iminente. A causa subjacente para esses problemas é percebida como uma demanda crescente por produtos agrícolas que enfrentam recursos naturais finitos, tais como terra, água e potencial genético. (BRUINSMA, 2009 p.3).

A escassez desses recursos naturais finitos seria agravada pelas exigências de concorrentes, originários de urbanização, usos industriais e uso na produção de biocombustíveis, por forças que mudariam sua disponibilidade como as alterações climáticas e a necessidade de preservar os recursos para as gerações futuras. Apesar de ainda existir um potencial para o aumento nas áreas de lavouras, entre cinco milhões e sete milhões de hectares $(0,6 \%)$ de terras agrícolas são perdidas anualmente por causa da aceleração da degradação da terra, bem como da urbanização, provocando assim a redução no número de fazendas à medida que cada vez mais pessoas migram para as cidades.

Figura 18: Terra arável per capita

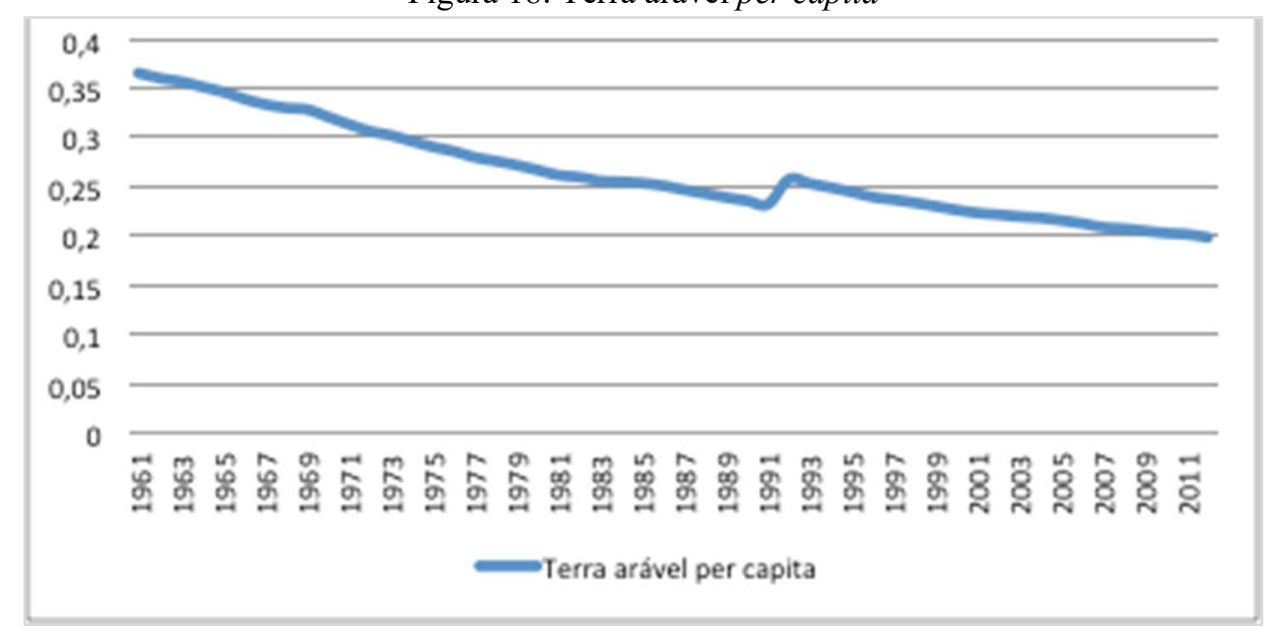

Fonte: (WORLD BANK, 2014c)

O aumento da população significa que a quantidade de terra cultivada por pessoa também está diminuindo severamente: de 0,4 hectare, em 1961, para 0,2 hectare, em 2011 (conforme a figura 18). (HOEKSTRA; MEKONNEN, 2012 p.3236; WORLD BANK, 2014c).

Atualmente, cerca de $12 \%$ (mais de 1500 milhões de hectares) da superfície terrestre $(13.400$ milhões hectares) é utilizada na produção agrícola (terra arável e das terras com cultivo permanente). Essa área representa um pouco mais de um terço (36\%) da terra que se estima ser de algum grau apropriado para a produção das colheitas. $\mathrm{O}$ fato de que continuam a existir 
alguns 2,7 bilhões hectares com potencial de produção (inexplorados) sugere que há ainda margem para uma maior expansão das terras agrícolas. No entanto, há também uma percepção, pelo menos em algumas áreas, de que não existe mais, ou há pouca terra apropriada para produção de colheitas. Isso acontece porque algumas das terras que poderiam potencialmente ser usadas para a agricultura estão sujeitas a restrições ecológicas e de poluição, enquanto outra parte é protegida ou ocupada por outros usos da terra (por exemplo, florestas e bosques, assentamentos humanos). (BRUINSMA, 2009 p.9).

A expansão de terra no setor da pecuária é preocupante, tendo em conta o encargo que coloca sobre os recursos naturais a nível global. No início do século XXI, 7\% de terra livre de gelo da Terra foi usada para o cultivo do consumo humano direto e $30 \%$ foi usada para a produção de alimentos e aragem para os animais (incluindo terras aráveis e pastagens) (LENKA; LENKA; BISWAS, 2015). Dado o uso tradicional das terras menos produtivas para pastagem de animais, esta proporção de 4:1 de terra dedicada à alimentação animal em relação ao uso para alimentação humana não é recente. Porém a rápida industrialização contemporânea da produção de animais, juntamente com a crescente produção de não ruminantes (suínos e frangos) em relação aos ruminantes (bovinos, ovinos e caprinos, que pastam principalmente), está aumentando a demanda por terras aráveis, água e nutrientes associados a seu uso.

Segundo FADEL (1999), porcos e galinhas respondem por 70\% da produção total de carne (em peso por carcaça), onde os sistemas industrializados fornecem mais da metade da carne de porco e quase três quartos da produção de aves. A industrialização tem sido associada com a concentração regional e pode ser observada na maioria dos países desenvolvidos e em desenvolvimento (GALLOWAY et al., 2007 p.622-623).

Sistemas industrializados são baseados em dietas para não ruminantes contendo grandes quantidades de grãos de cereais e refeições de petróleo, em contraste com os sistemas tradicionais, que utilizam grandes quantidades de subprodutos e resíduos de produtos e, para os ruminantes, resíduos de colheitas e forrageiras. A produção de suínos e aves industrializadas responde por mais de $75 \%$ da concentração de alimento à base de cereais ou oleaginosas. Sua influência sobre os recursos para a alimentação animal é, portanto, bastante surpreendente. Embora ruminantes consumam $69 \%$ dos alimentos para animais em geral, não ruminantes consomem $72 \%$ de toda a alimentação animal, que é cultivada em terras aráveis. Com base em todos os alimentos consumidos, os ruminantes convertem isso em carne de maneira muito 
menos eficiente do que não ruminantes, devido à menor qualidade dos alimentos para animais e outros fatores, mas a maioria dos alimentos para ruminantes é forragem da terra e outros materiais que os seres humanos não podem comer. Não ruminantes, por outro lado, consomem grandes quantidades de alimentos cultivados em terras nas quais poderiam se cultivar alimentos, trazendo um conflito inevitável com outros usos potenciais para terras aráveis. Assim, como a produção animal industrial continua a aumentar, a concorrência entre a produção de alimentos para animais e de culturas alimentares para a terra e outros recursos irão aumentar. (STEINFELD et al., 2006).

O crescimento da produção de não ruminantes em relação aos ruminantes tem sido impulsionada pela queda dos preços reais para os cereais e as eficiências de alimentação de conversão mais elevadas relativas de não ruminantes. Se os grãos se tornam muito mais caros, a vantagem econômica de não ruminantes pode diminuir. No entanto, as quantidades de terra de pastagem, resíduos de colheitas e subprodutos potencialmente disponíveis não são suficientes para permitir um grande aumento na produção de ruminantes, especialmente dada a recente expansão dos biocombustíveis (ESCOBAR et al., 2009). Assim, aumentos projetados de demanda por carne serão provavelmente alcançados principalmente por não ruminantes. (GALLOWAY et al., 2007 p.622-623).

Os consumidores têm contribuído para a industrialização de uma parte da produção de ruminantes através do desenvolvimento de confinamento e o rápido crescimento nos setores de suínos e aves. Embora a necessidade de terra para pastagem não diminui, o número de animais ruminantes globalmente continua a aumentar a uma taxa muito mais lenta do que a de não ruminantes. E enquanto isso, a utilização de terras aráveis, sem dúvida, tem maiores custos para a sociedade e para o meio ambiente, incluindo o conjunto de impactos ambientais associados à produção agrícola intensiva, tais como uso de pesticidas e/ou fertilizantes e perdas, a conversão em escala de terra integral em algumas áreas, custo de oportunidade grande com relação a outros usos humanos e ambientais (produção de alimentos ou combustível para os seres humanos, habitat animal, etc.). Tal como acontece com água e nitrogênio, muitos destes efeitos negativos sobre os recursos de terra não estão incluídos no preço final do produto vendido (GALLOWAY et al., 2007 p.623).

Um exemplo disso é o consumo de carne de porco e frango. Calcula-se que o consumo da carne desses animais no Japão implica a utilização de cerca de $2.2 \times 10^{6}$ hectares de terras em outros 
países para a produção de alimentos para animais, que é igual a 50\% das terras aráveis no Japão, sem mencionar os determinantes do uso da terra e conversão de terras em uma determinada área. (PRETTY et al., 2001). Outro exemplo é a rápida expansão da produção de soja no Brasil, que foi acompanhada por seus efeitos devastadores sobre a savana e floresta tropical (GALLOWAY et al., 2007). Essa expansão tem sido associada ao crescimento da produção mundial de carne (FEARNSIDE, 2001; KAIMOWITZ, D.; SMITH, 2001) em que cerca de 11 X $10^{6}$ hectares no Brasil são utilizados para alimentar porcos e frangos industrializados, com um pouco mais da metade da área plantada com essa produção para exportação. A maioria das terras do Brasil usada para aumentar as exportações de soja está associada à produção de porcos e de frango para a Europa, embora, no passado, a China emergiu como um grande importador da soja brasileira. A China se tornou a responsável por cerca de $20 \%$ dos cerca de $4 \times 10^{6}$ hectares de soja exportado pelo Brasil. (KAIMOWITZ, DAVID et al., 2004).

A agricultura - incluindo colheitas, gado, florestas, pescas e aquicultura - é a principal atividade humana responsável pela gestão dos recursos naturais a nível local e regional. $40 \%$ das terras do planeta são utilizadas para cultivos e pastagens, e 70\% de toda a água doce é destinada à irrigação na produção de alimentos para pessoas e um abastecimento alimentar estável para o gado. (FAO, 2013 p.219). Os resultados de tal utilização em larga escala de terra e de recursos hídricos produzem cada vez mais ambientes ameaçadores. (ALIGLERI; ALIGLERI; KRUGLIANSKAS, 2009 p.54). Por exemplo, a agricultura é a principal fonte de nitrato de amônia e poluição, tanto em águas subterrâneas e de superfície e é um dos principais contribuintes para a poluição dos cursos de água de fosfato. As emissões de gases com efeito de estufa (GEE) provenientes da agricultura, da silvicultura e outros usos da terra contribuem significativamente para a ameaça do aquecimento global. Os setores de terra são responsáveis por quase $30 \%$ de todas as emissões de GEE induzidas pelo homem na atmosfera, uma contribuição comparável à do setor da energia e muito superior no total das emissões de transporte. A produção agrícola e pecuária é, de forma isolada, responsável por metade do metano e dois terços do óxido nitroso emitido para a atmosfera pela atividade humana. Tais impactos negativos para a atmosfera, solo e água têm, por sua vez, gerado impacto negativo na produção agrícola e no bem-estar humano. $\mathrm{O}$ aumento da salinidade do solo, esgotamento de aquíferos e redução na degradação do solo atinge altos índices, que colocam em risco a capacidade e habilidade dos agricultores produzirem de forma pura e com segurança alimentar. (FAO, 2013 p.220). 
Embora a agricultura persista em ser um dos principais utilizadores de terra e água, ela poderá buscar novas formas de manter esses recursos a fim de manter a sua viabilidade, e ao mesmo tempo minimizar os impactos negativos sobre os ecossistemas e o bem-estar humano. Garantir alimentação e água suficiente para uma população mundial e ao mesmo tempo alcançar um nível de desenvolvimento rural sustentável exige uma gestão responsável dos recursos naturais e, portanto, em um sistema de agricultura sustentável.

A pecuária, desde muito tempo fornece comida, fibra, fertilizante, combustível, tração, e transporte para os seres humanos e exerceu impactos significativos sobre a evolução das sociedades humanas. (GALLOWAY et al., 2007 p.622). No entanto, mudanças significativas estão ocorrendo na composição da produção de gado. O crescimento do gado tem diminuído gradualmente, de quase $2 \%$ ao ano na década de 1960 para menos de $1 \%$ ao ano ao longo da última década. O suíno tem experimentado um declínio ainda maior, a partir de uma taxa de crescimento de mais de $4 \%$ ao ano, há 50 anos para apenas $0,8 \%$ ao ano desde 2000 . Os níveis de estoques de aves de capoeira continuam a ser significativos, crescendo a uma média de 3\% ao ano. A produção de animais vivos - e a alimentação econômica mundial - é cada vez mais impulsionada por uma mudança na dieta e nos padrões de consumo de produtos pecuários. Durante a última década, o consumo de carne nos países em desenvolvimento da Ásia (onde se concentra a maior parte do aumento populacional mundial) tem crescido em cerca de $3 \%$ ao ano, e o consumo de produtos lácteos aumentou em quase 5\% ao ano. (FAO, 2013 p. 138).

Globalmente, a produção de gado é o maior utilizador de terras agrícolas. Do lado negativo, há implicações ambientais associadas à expansão da produção pecuária. Por exemplo, por meio da expansão da terra para o desenvolvimento de ações pecuária, o crescimento do setor tem sido uma força principal no desmatamento na América Latina e no Caribe e em outras regiões. Operações de gado em escala intensiva, principalmente nos países industrializados, e especialmente em regiões em desenvolvimento, são uma importante fonte de problemas ambientais por meio da produção de afluentes. Em paralelo, o crescimento no setor de ruminantes contribui para a concentração de gases de efeito estufa na atmosfera através de emissões de metano e óxido nitroso a partir do processo digestivo dos animais. (FAO, 2013 p.140).

A pecuária é também responsável por aproximados 18\% dos GEEs emitidos no mundo. Dentre os gases do efeito estufa produzidos pela pecuária, os mais significativos são $\mathrm{CO}_{2}, \mathrm{CH}_{4}$ e $\mathrm{N}_{2} \mathrm{O}$. 
Grandes quantidades de GEE são provenientes do metano emitido pela fermentação entérica dos ruminantes, da queima de resíduos agrícolas, da decomposição da matéria orgânica e do uso de combustíveis fósseis. A produção de metano por bovinos é conhecida como metanogênese, onde o $\mathrm{CH}_{4}$ é produzido pelo uso de energia proveniente da dieta pelo animal e representa uma perda em eficiência alimentar. As emissões de metano pelos bovinos estão entre $2 \%$ a $12 \%$ da energia bruta ingerida (conforme dados na tabela 13). O Painel Intragovernamental sobre Mudanças Climáticas - IPCC (ou em inglês Intergovernmental Panel on Climate Change) calcula que um bovino emita em média 1,1 tonelada de $\mathrm{CO}_{2}$ eq $\left(\mathrm{CO}_{2}\right.$ equivalente) por ano na forma de metano entérico $\left(1 \mathrm{~kg}\right.$ de metano $=21 \mathrm{~kg}$ de $\left.\mathrm{CO}_{2} \mathrm{eq}\right)$. Consequentemente, a atividade agropecuária com um rebanho de 211 milhões de cabeças, representa $37 \%$ das emissões de GEE brasileiras, atingindo um total de $446 \mathrm{Mt} \mathrm{CO}_{2}$ eq. Logo, a agropecuária se tornou o $3^{\circ}$ setor mais emissor de GEE, logo atrás do setor de Energia e Mudança no Uso da Terra. (FAO, 2013 p.140).

Tabela 13: Emissões de $\mathrm{CH}_{4}$, em gramas por dia, acumulado até abate

\begin{tabular}{|c|c|c|c|c|c|c|}
\hline \multirow[b]{2}{*}{ Tratamento } & \multirow[b]{2}{*}{ GMD Kg/dia } & \multirow[b]{2}{*}{ Dias até Abate * } & \multicolumn{4}{|c|}{ Emissões de $\mathrm{CH}_{4}$} \\
\hline & & & g/dia & Acumulado (Kg) & g. $\mathrm{CH}_{4} / \mathrm{kg}$ ganho $\mathrm{PV}$ & $\mathrm{Kg}$ ano \\
\hline Pasto adubado ** & 0,47 & 766 & 89,9 & 68,8 & 191 & 32,8 \\
\hline Não adubado ** & 0,3 & 1200 & 92,8 & 111 & 309 & 33,9 \\
\hline iLP1*** & 0,46 & 783 & 112 & 87,6 & 243 & 40,9 \\
\hline iLPF1*** & 0,46 & 783 & 88 & 68,9 & 191 & 32,1 \\
\hline iLP6*** & 0,33 & 1091 & 97 & 106 & 294 & 35,4 \\
\hline
\end{tabular}

Fonte: (CSR/UFMG, 2015)

Na pecuária, a produtividade animal se relaciona com o consumo alimentar e a eficiência de ganho de peso vivo, gerando emissões de metano entérico variadas. $\mathrm{O}$ baixo índice produtivo da pecuária bovina de corte se torna o grande problema na emissão de GEEs, pois é o metano produzido por animais com baixas taxas de ganho de peso (ou perdendo peso na seca) e por vacas vazias ou por novilhas que entraram tarde na reprodução, que aumenta a relação entre a produção de metano por quilograma de carne ou de leite produzido. E isso pode ser agravado, pois um aumento de temperatura da ordem de $3^{\circ} \mathrm{C}$ (aumento previsto pelo IPCC até 2100) poderá causar a perda de até $25 \%$ da capacidade de pastagens para bovinos de corte, o que equivaleria a um aumento de custo de produção de $20 \%$ a 45\%. Essa perda de área deve ocorrer principalmente por causa do aumento de 30 a 50 dias do período sazonal de seca nas áreas hoje 
aptas para pastagens. Todos esses fatores reforçam a necessidade pela busca de sistemas mais eficientes e adaptados ao novo cenário climático mundial. (FAO, 2013 p.140).

Diversas estratégias podem ajudar a mitigar a emissão de metano, como a melhoria da dieta, incluindo aumento de concentrado volumoso inclusão de lipídios e uso de aditivos protéicos, além do uso de aditivos alimentares (antimicrobianos, óleos essenciais, probióticos, entre outros) que promovam eficiência metabólica. A título de ilustração, bovinos de corte criados em pasto, em sistemas de integração lavoura/pecuária, e posteriormente terminados em confinamento, emitiram em média 40,3 kg de metano/cabeça/ano, durante três anos em um período experimental, indicando que os animais com maiores ganhos diários de peso podem emitir menores quantidades do gás. (FAO, 2013 p.140).

Outra alternativa é a redução do rebanho, mantendo o mesmo nível de produtividade. O aumento de produtividade pode ser alcançado pela adoção de sistemas de integração lavourapecuária-floresta (iLPF) como forma de obter uma maior quantidade de produtos em uma mesma área. Nesse aspecto, sistemas de produção integrados como a iLPF apresentam grande potencial para intensificação da produção pecuária, proporcionando ganhos produtivos, econômicos e ambientais. Estudos sobre ecossistemas de pastagens nos biomas da Amazônia, do Cerrado e da Mata Atlântica, considerando os estoques de carbono no solo em comparação à vegetação nativa, indicaram que, de modo geral, solos sob pastagens bem manejadas em sistemas de integração lavoura/pecuária acumulam carbono em níveis semelhantes ou superiores à vegetação nativa. Por outro lado, a degradação das pastagens promove perda do carbono acumulado. (FAO, 2013 p.140).

No entanto, a maioria da pecuária brasileira continua abaixo de suas reais potencialidades, mantendo um sistema tradicional extensivo de baixa taxa de lotação $(<1 \mathrm{UA} / \mathrm{ha})$ e produtividade $(<120 \mathrm{~kg}$ de peso vivo ou 4 arrobas/ha/ano). Como visto, o aumento histórico da produção foi obtido através da expansão das novas áreas de pastagens no lugar de áreas de matas e florestas, com grande impacto ambiental. Portanto, estratégias que permitam aumentar a taxa de lotação, fertilidade do rebanho, o ganho médio diário, o peso da carcaça e o retorno financeiro por área, são hoje necessárias para acomodar o crescimento da pecuária sem novos desmatamentos. (CSR/UFMG, 2015; FAO, 2013 p.140). 
A pecuária utiliza 3,4 bilhões de hectares de pastagens e da produção de cerca de um quarto das terras agrícolas do mundo. No total, o gado faz uso de mais de dois terços da superfície do mundo sob a agricultura, e um terço da área total da terra global. A criação de gado é a única fonte de subsistência para, pelo menos, 20 milhões de famílias de pastores, e um importante, muitas vezes a principal, fonte de renda para pelo menos 200 milhões de famílias de pequenos agricultores na Ásia, África e América Latina. O gado fornece energia para cultivar, pelo menos, 320 milhões de hectares de terra ou de um quarto do total da área cultivada global. $\mathrm{O}$ gado fornece os nutrientes de plantas para grandes áreas de terras cultiváveis. (DE HAAN et al., 1997 p.12).

O rápido crescimento do setor de carnes tem sido sustentado pelo aumento da demanda por carne de aves, que tem consistentemente aumentado em cerca de três vezes a taxa de crescimento da população sobre cada uma das últimas cinco décadas. Para outras carnes, o crescimento da produção per capita estagnou ou permanece insignificante, especialmente para ruminantes (bovinos, ovinos e caprinos) e suínos (exceto na China). Além disso, em muitos países em desenvolvimento, onde a necessidade de aumentar o consumo de proteína é maior, o setor produtivo não tem participado na "revolução pecuária". Por exemplo, ainda existem cerca de 20 países em desenvolvimento onde o consumo per capita de carne é inferior a $10 \mathrm{~kg} / \mathrm{ano}$, em comparação com uma média de $80 \mathrm{~kg} /$ ano em países desenvolvidos. Razões culturais ou religiosas podem explicar esse nível de consumo em alguns países, mas as capacidades produtivas baixas são, em geral, a principal causa. (FAO, 2013 p.140).

O crescimento da produção e do consumo mundial de leite tem sido muito menos dinâmico. Até recentemente, o crescimento per capita estava em grande parte estagnado, mantendo-se inalterado durante várias décadas. O consumo per capita nos países em desenvolvimento continua a ser muito inferior ao dos países industrializados, em parte refletindo os hábitos de consumo, bem como baixa renda e pobreza. Porém essa diferença está gradualmente diminuindo, especialmente no Leste e Sul da Ásia. Por exemplo, na Ásia Oriental, a ingestão de produtos lácteos per capita mais do que duplicou na última década. (FAO, 2013 p.142).

A demanda pela alimentação por cereais é muitas vezes considerada um elemento dinâmico e por isso afeta as condições do crescimento do setor dos cereais, especialmente nos países desenvolvidos. Recentemente, no entanto, particularmente nas regiões em desenvolvimento, esse dinamismo tem sido praticamente inexistente e o crescimento na produção pecuária tem 
se sobressaído, com um crescimento despojado em alimentos compostos por animais. Portanto, o mundo está obtendo mais carne, leite e ovos por quilograma de alimento à base de cereais, o que aponta para ganhos de produtividade na criação e produção de animais (indicados na figura 19). Algumas dessas melhorias estão relacionadas com modificações na composição da produção de gado, assim como aves requerem quantidades muito pequenas de alimentação cereal por quilograma de carne do que, por exemplo, carne de bovino. Outras forças também levaram a redução no consumo de grãos. Entre elas está o crescente uso de leguminosas na alimentação de gado. A produção mundial de soja cresceu mais de 4\% ao ano na última década e em 5\% na década de 1990. Por implicação, a produção e o consumo de farelo de soja como ração aumentou os mesmos níveis, o que sugere um aumento relativo no uso de leguminosas na alimentação. (FAO, 2013 p.144).

Figura 19: Previsão de Produção e Comércio Mundial Pecuarista em 2013

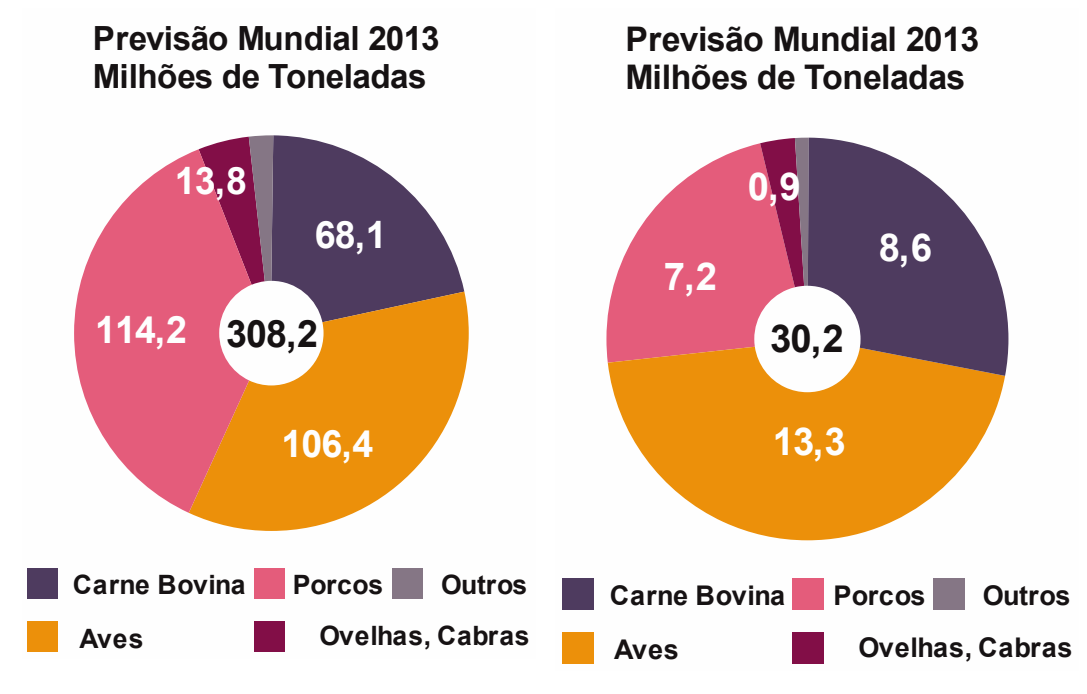

Fonte: (FOUNDATION, 2014 p.10)

O crescimento contínuo da participação dos países em desenvolvimento na produção pecuária mundial está associado a uma mudança de pastagem e de produção "caseira" para sistemas de alimentação com rações concentradas. Consequentemente, as mudanças nos sistemas de produção tendem a aumentar os índices médios de consumo de grãos desses países em desenvolvimento, equilibrando com as tendências opostas que resultam de melhorias na produtividade. (FAO, 2013 p.144). 


\subsubsection{Perdas e Desperdício na Agropecuária}

De acordo com FAO (2015) a perda de alimentos e resíduos alimentares refere-se à diminuição de alimentos em fases subsequentes da cadeia de abastecimento alimentar destinada ao consumo humano. Essa perda ou desperdício pode ocorrer em toda a cadeia produtiva, desde a produção inicial até o consumo final das famílias, de forma acidental ou intencional, mas acaba por conduzir a menos alimentos disponíveis. $\mathrm{O}$ alimento que é derramado ou estragado antes de atingir o produto final é também denominado como perda.

A causa da perda pode ser a ocorrência de problemas na colheita, armazenagem, embalagem, transporte, infraestrutura ou mecanismo de mercado/preço, bem como quadros institucionais e jurídicos. Por exemplo, bananas colhidas que caem de um caminhão considera-se perda de alimentos. Alimentos que estão aptos para consumo humano, mas não são consumidos porque estão estragando ou foram deixados estragar e passam a ser descartados são considerados como desperdício de alimentos. Isso pode ser por causa de regras rígidas ou incompreendidas datas de marcação, armazenamento inadequado, compra ou práticas de cozinha. (FAO, 2015).

Segundo FAO (2015 p.1) as consequências das perdas e desperdício de alimentos são muitas: representam um desperdício de recursos utilizados na produção, como terra, água, energia e insumos; produzem emissões desnecessárias de $\mathrm{CO}_{2}$, repercutem em perda de valor econômico dos alimentos produzidos pois têm um impacto direto e negativo sobre a renda dos agricultores e consumidores (considerando que muitos pequenos agricultores vivem à margem de insegurança alimentar, uma redução das perdas de alimentos poderia ter um impacto imediato e significativo sobre a sua subsistência).

Cerca de um terço do alimento produzido para consumo humano é perdido ou desperdiçado globalmente, o que é cerca de 1,3 bilhões de toneladas por ano (figuras 20 e 21). 
Figura 20: Produção por grupo de Commodities e região em 2007 (milhões de toneladas)

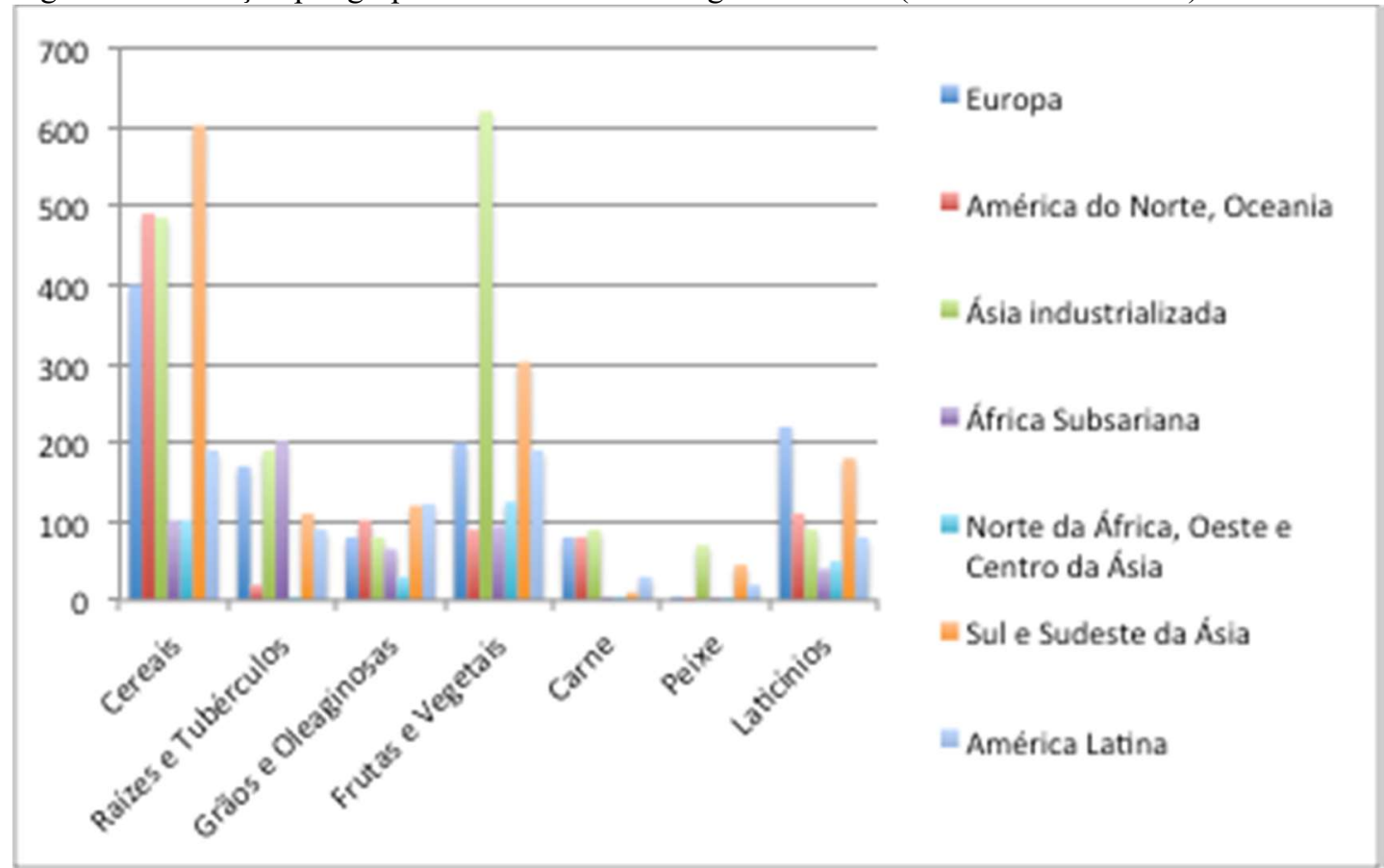

Fonte: (GUSTAVSSON et al., 2011 p.4)

O alimento é desperdiçado durante todo o processo, ou seja, desde o inicial na produção agrícola até a última etapa que finda no consumo final das famílias. Em países de média e alta renda, uma grande quantidade de alimentos é desperdiçada, mesmo que ainda esteja adequada para consumo humano.

Figura 21: Perda e Desperdício (per capita) de alimento por região e fase em 2007

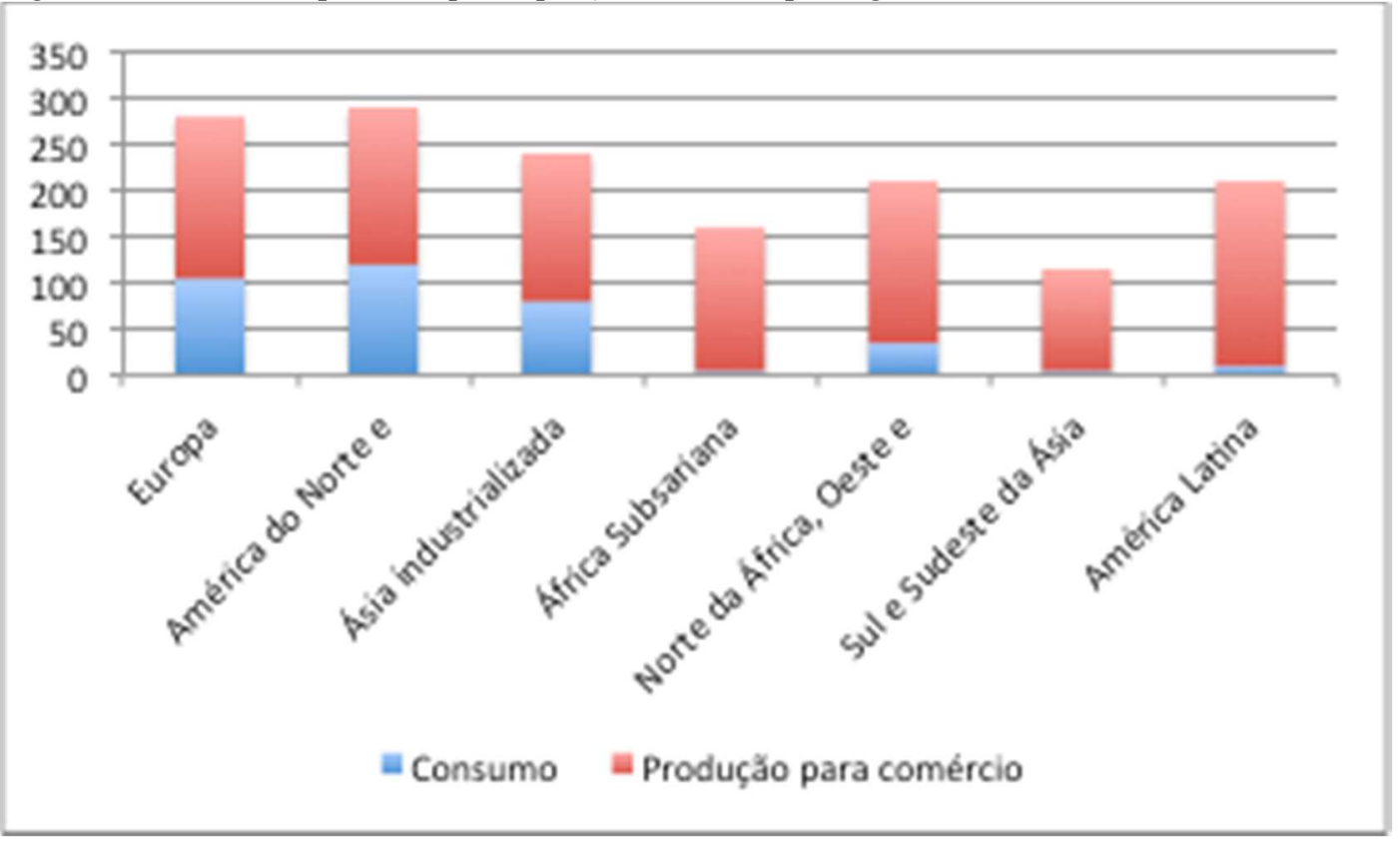

Fonte: (GUSTAVSSON et al., 2011 p.5) 
Uma perda significativa de alimentos e resíduos, no entanto, também ocorre no início da cadeia de abastecimento alimentar. Em países de baixa renda (conforme visto na figura 21), o alimento é perdido, especialmente durante os estágios iniciais e intermediários da cadeia de abastecimento alimentar e uma quantidade muito menor de alimento é desperdiçada ao nível do consumidor.

Na figura 21 é possível perceber que a perda de alimentos per capita na Europa e na América do Norte é de 120-170 kg/ano; na África Sub-Sahariana e Sul/Sudeste da Ásia é 280-300 $\mathrm{kg} / \mathrm{ano}$. O total de produção per capita consumida é, na Europa e na América do Norte, cerca de $300 \mathrm{~kg} / \mathrm{ano}$ e, na África Sub-Sahariana e Sul/Sudeste da Ásia 460 kg/ano. A quantidade per capita de alimentos desperdiçados pelos consumidores na Europa e na América do Norte é 95$115 \mathrm{~kg} / \mathrm{ano}$, enquanto que este número na África Sub-Sahariana e Sul/Sudeste da Ásia é de apenas 6-11 kg/ano. Esse dado leva ao entendimento de que as perdas de alimentos nos países industrializados são tão elevadas como nos países em desenvolvimento, mas nos países em desenvolvimento mais de $40 \%$ das perdas de alimentos ocorrem em níveis pós-colheita e processamento, enquanto em países industrializados, mais de $40 \%$ das perdas de alimentos ocorrem a níveis de retalho e consumidores. Os resíduos alimentares no nível consumidor em países industrializados (222 milhões de toneladas) são quase tão altos quanto o total da produção de alimentos líquidos na África Sub-Sahariana (230 milhões de toneladas).

\subsubsection{Consequências do uso de recursos naturais na Agropecuária}

O período geológico "Holoceno" é marcado por condições ambientais extremamente previsíveis e estáveis dos últimos 10.000 anos, as quais promoveram lucro (com o capital natural oferecido por uma biosfera estável) associado ao trabalho humano e permitiram o estabelecimento de comunidades humanas e a evolução para sociedades modernas atuais. Porém, segundo estudos atuais do sistema terrestre, o mundo passou a atuar em um novo período chamado "Anthropocene", em que as atividades humanas são as maiores responsáveis pelas alterações à escala planetária. Dado o ritmo e a escala dessas alterações, já não se pode excluir com exatidão a possibilidade de chegar a pontos críticos de inflexão que poderiam abruptamente e irreversivelmente mudar as condições de vida na Terra. (ZALASIEWICZ et al., 2008). 
A vida na Terra depende de alguns processos ambientais interligados, operando em grandes escalas temporais e espaciais. As correntes oceânicas trazem nutrientes das profundezas para apoiar os produtivos ecossistemas marinhos. Geleiras funcionam como instalações de armazenamento de água gigantes, enquanto a ação glacial desenvolve solos férteis e ajuda a regular o clima. O dióxido de carbono na atmosfera é dissolvido e armazenado nos oceanos, ajudando a manter o clima estável. Ciclos de nitrogênio e fósforo fornecem nutrientes essenciais para que as plantas cresçam, as reações químicas formam uma camada protetora de ozônio, e as grandes camadas de gelo polares ajudam a regular a temperatura global. Isso torna o planeta Terra um lugar complexo e dessa forma não é de se esperar que haja uma única métrica capaz de capturar todos os elementos e dinâmicas de sistemas complexos da natureza, interligados nem como eles se relacionam com as atividades humanas de forma semelhante - complexos e interligados. No entanto, pode-se começar a capturar essa complexidade analisando alguns indicadores, correlacionando-os e vinculando-os a algumas variáveis. (STEFFEN et al., 2011 p. 845-848).

Conforme já salientado, os recursos naturais são divididos em renováveis (repostos ou que podem ser reaproveitados e/ou revitalizados após o seu uso) naturalmente, ou através da ação humana, e não-renováveis (não possuem possibilidade de renovação em um curto ou médio período de tempo). (CAVALCANTI; FURTADO, 1995; SKINNER, 1996).

De acordo com a World Wide Funde for Nature - WWF, a perda e degradação de habitat, ou seja, do ambiente em que os seres vivos vivem é a principal causa de perda de biodiversidade do planeta (WWF, 2014). Como alternativa a esse problema, o estabelecimento e a manutenção de áreas protegidas poderia ajudar tanto na preservação da biodiversidade como do capital natural, tendo como elemento-chave a identificação das áreas mais importantes e o monitoramento de seu estado de forma física, espacial e temporal.

As imagens de satélite tornam possível o monitoramento das mudanças no uso e cobertura da terra ao redor do mundo em diferentes resoluções. Compreender a causa dessas mudanças, tais como desmatamento, expansão da agricultura ou fragmentação por estradas pode auxiliar no desenvolvimento de estratégias de conservação eficazes. Dados de uso da terra também podem ser analisados para ajudar a entender os trade-offs e as consequências das escolhas dos seres humanos para seu consumo e comercialização. (WWF, 2014 p. 73). Atualmente há bancos de dados, como por exemplo, o Global Land Cover (GLC) da Food and Agriculture Organization 
of United Nations (FAO), destinados à avaliação dos recursos terrestres e hídricos da Terra, baseados em uma combinação de fontes nacionais, regionais e subnacionais de cobertura da terra. (FAO, 2013). Um segundo exemplo é o banco de dados do Internacional Institute for Applied Systems Analysis (IIASA) em que são analisados dados de uso da terra para examinar as pressões nas florestas. De acordo com esse instituto, as florestas do planeta de forma geral estão diminuindo em área e em qualidade e isso gera graves impactos sobre a biodiversidade uma vez que a maioria das espécies terrestres vive em florestas - e com a sobrecarga na capacidade de absorção de emissões de carbono, contraem consequências que afetam os serviços dos ecossistemas, tais como fornecimento de água e prevenção de inundações. (WWF, 2014 p.78).

De acordo com um modelo desenvolvido pela WWF, as tendências atuais de desmatamento apontam para perdas catastróficas e irreversíveis de biodiversidade e mudança climática descontrolada. As estatísticas indicam que até 2030, a perda será estimada em um extra de 69 milhões de hectares de florestas em todo o mundo. Com base nisso, o modelo da WWF sugere que, com políticas governamentais e utilização mais inteligente da terra, seria possível atender a demanda mundial por alimentos e por produtos florestais sem uma maior perda de florestas entre agora e 2030. Após este tempo, porém, se o consumo continua a crescer, o resultado poderá se resumir em perdas significativas de outros ecossistemas importantes, tais como pastagem, e grandes aumentos nos preços dos alimentos. Além disso, o aumento da procura de madeira, em particular para a bioenergia até 2050 significaria um aumento de $25 \%$ na área de floresta natural visando à gestão para a colheita comercial, juntamente com um extra de 250 milhões de hectares de novas plantações de árvores. Estas previsões levantam questões importantes em torno de como gerenciar os trade-offs, e ajudar a apontar para possíveis soluções - como melhor uso de recursos, de forma mais eficaz, acompanhada da redução de práticas agrícolas intensivas, redução do consumo de carne acompanhada da utilização intensiva de terras em países de alta renda. (WWF, 2011). Em vista disso, a análise do uso de recursos naturais especificamente na alimentação se faz necessária para melhor entendimento na aplicação do estudo.

Analisando que os recursos naturais renováveis não são necessariamente duráveis por longos períodos de tempo ou infinitos, ou seja, sua disponibilidade poderá extinguir (destacado pela tabela 14), torna-se necessário o desenvolvimento de medidas e/ou a fim de minimizar os efeitos da inevitável exploração da biodiversidade, considerando a importância do tempo nos processos 
de renovação da natureza e do controle do consumo. (BRUNDTLAN, 1987; DE VRIES; VAN KEULEN; RABBINGE, 1995; WWF, 2011;2014).

Tabela 14: Ações, Causas e Consequências de ações humanas ao Meio Ambiente

\begin{tabular}{|cll|}
\hline \multicolumn{1}{|c}{ Ação } & \multicolumn{1}{c|}{ Causas } & \multicolumn{1}{c|}{ Consequências } \\
\hline \multirow{2}{*}{ Desflorestamento } & Agricultura Intensiva & Redução da biodiversidade \\
& $\begin{array}{l}\text { Exploração de minas, de pedreiras e de petróleo } \\
\text { Construção de barragens, túneis e estradas } \\
\text { Economia / política dos países }\end{array}$ & $\begin{array}{l}\text { Desaparecimento de culturas } \\
\text { Infertilidade do solo }\end{array}$ \\
\hline \multirow{2}{*}{$\begin{array}{c}\text { Poluição das Águas } \\
\text { (Superficial e }\end{array}$} & Resíduos urbanos divididos em: & Diminuição de oxigênio \\
Subterrânea) & Resíduos industriais & Ameaças à: \\
& & Qualidade de vida \\
\hline \multirow{3}{*}{ Poluição dos Solos } & Agricultura (fertilizantes e inseticidas) & Saúde \\
& Lixões & Meio Ambiente \\
\hline & & Contaminação do solo \\
& Atividade industrial & Perda de nutrientes \\
\hline \multirow{2}{*}{ Poluição da Atmosfera } & Circulação rodoviária & Contaminação da vegetação \\
& & Contaminação aos animais \\
\hline Esgotamento dos & Abuso dos recursos naturais & Smog (fumo e névoa) \\
& Destruição dos recursos naturais & Chuvas Ácidas \\
\hline
\end{tabular}

Fonte: desenvolvido pela autora

O principal desafio da política do desenvolvimento sustentável é encontrar um equilíbrio entre a exploração dos recursos naturais e a conservação desses, uma vez que grande parte deles não são renováveis.

Segundo WWF (2015) a expressão “desenvolvimento sustentável” conheceu a sua popularidade a partir do início dos anos 1990 e se refere ao uso dos recursos naturais de forma a não esgotá-los, mantendo ou renovando os ciclos de reposição. Seguindo esse entendimento, a humanidade deve preservar (proteger) e conservar (utilizar de forma racional objetivando a renovação) a natureza.

Estudos recentes têm produzido novas análises aprofundadas sobre o assunto. Uma abordagem chamada de "Limite Planetário" (ou na sigla em inglês PB - Planetary Boundaries), ilustrada na figura 22, foi desenvolvida com o objetivo de definir um espaço operacional seguro para as sociedades humanas com o fim de se desenvolverem e prosperarem, com base na evolução do nosso entendimento do funcionamento e resiliência do sistema Terra. 
Figura 22: Limites do Planeta

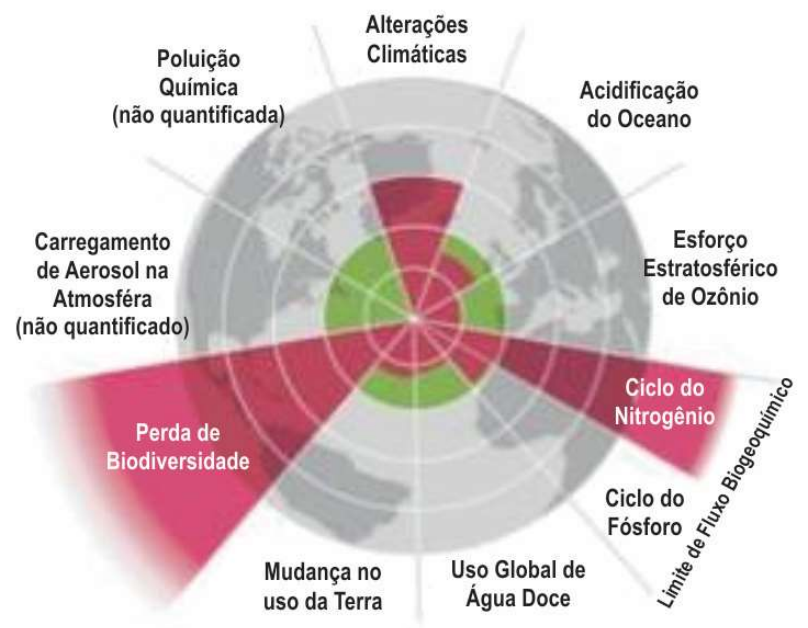

Fonte: (WWF, 2014 p.67)

Desde a sua introdução, essa abordagem tem sido objeto de escrutínio científico e ao mesmo tempo interesse e discussões no âmbito da política, governança, e setores de negócios como uma abordagem para informar os esforços em prol da sustentabilidade a nível global. (STEFFEN et al., 2015 p.737). O Limite Planetário tem o intuito de orientar as sociedades humanas através da definição de um "espaço operacional seguro" em que a sociedade humana pode continuar a se desenvolver e ao mesmo tempo prosperar. Segundo STEFFEN et al. (2015 p.738) a proposição e o respeito a limites do planeta reduz a ameaça de que atividades antropogênicas (ou alterações bruscas) inadvertidamente conduzam o sistema da Terra a um estado de instabilidade. O Limite Planetário contempla nove processos ou limites, que estão sendo modificados pela ação humana.

Para cada um desses processos, foi realizada uma tentativa de definir, com base no melhor conhecimento científico disponível, limites seguros a fim de assegurar a estabilidade do planeta. Através desses limites planetários se estabelece um "espaço operacional seguro para a humanidade", em que há uma melhor perspectiva de um futuro contínuo e próspero para futuras gerações.

As nove fronteiras identificadas são as alterações climáticas, a acidificação dos oceanos, perda de ozônio, a interferência com os ciclos globais de nitrogênio e fósforo, o uso global de água doce, mudança do sistema da terra, a perda de biodiversidade, carregamento de aerossol atmosférico (ainda não quantificados) e poluição química (ainda não quantificados). Enquanto 
exatos pontos de inflexão são impossíveis de determinar com qualquer grau de certeza, três fronteiras planetárias são avaliadas com certo grau de confiança pois seus limites já foram ultrapassados: a integridade da biosfera, mudanças climáticas e alterações no ciclo do nitrogênio. (STEFFEN et al., 2015).

O conceito de "limites planetários" sugere que a existência do mundo que se conhece e que se sustenta depende agora de um novo plano de ações. Isso reforça a necessidade de um novo paradigma de desenvolvimento, talvez acompanhado de um realinhamento de políticas de desenvolvimento, modelos de negócios e escolhas de estilo de vida da população. (STEFFEN et al., 2015).

\subsubsection{Variáveis influenciadoras na produção de alimentos pecuaristas}

Na criação de bovinos de corte, uma das maiores preocupações dos pecuaristas é o manejo alimentar, que pode impactar de forma direta a rentabilidade advinda do rebanho, e esses passam a ser conhecedores de nutrição animal e de características dos alimentos. Essa prática visa o manejo com o maior nível de eficiência e uma produção de mais qualidade, tendo em vista algumas das variáveis abordadas a seguir, que resultam em uma pecuária com desempenho desejado, recursos disponíveis e maior eficiência de mercado.

\subsubsection{Crescimento Populacional}

Nenhum censo foi realizado para se confirmar com exatidão a população de antigas civilizações. A população está sujeita a ciclos de crescimento e queda. Pelos últimos milhares de anos, não há evidência para provar que houve mais pessoas em algumas partes do mundo do que há hoje.

A figura 23 indica a distribuição da população nas áreas rural (que apresenta pouco crescimento) e urbana (que apresenta contínuo crescimento). 
Figura 23: População Mundial: Rural e Urbana

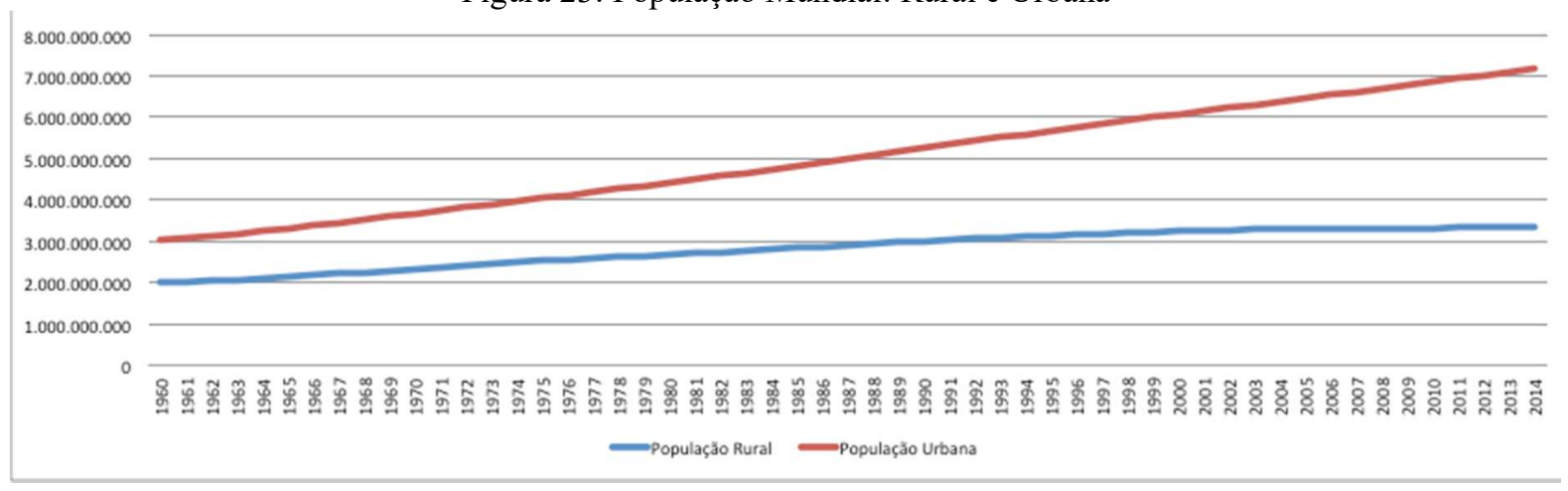

Fonte: desenvolvida pela autora com base em WORLD BANK (2014g) e WORLD BANK (2014i)

Dados e projeções (tabela 15) desenvolvidas pela Organização das Nações Unidas - ONU (ONU, 2003) indicam que uma desaceleração bastante drástica do crescimento demográfico mundial está por vir. A população mundial identificada no ano 2000 de 6.071 .000 milhões está projetada para crescer para 8.130 milhões em 2030 e 8.920 milhões em 2050. A taxa de crescimento da população mundial atingiu seu ápice na segunda metade da década de $1960 \mathrm{em}$ $2,04 \%$ ao ano e caiu para $1,35 \%$ na segunda metade da década de 1990 . Uma nova tendência de desaceleração vai trazê-la novamente para baixo, em 0,7\% em 2025-30 e 0,3\% em 2045-50. (ALEXANDRATOS et al., 2006 p.16).

Tabela 15: População mundial estimada e projetada

\begin{tabular}{|c|c|c|c|c|c|c|c|c|c|}
\hline & \multicolumn{5}{|c|}{ População (milhões) } & \multicolumn{4}{|c|}{$\begin{array}{l}\text { Níveis de Crescimento (\% por faixa } \\
\text { de ano) }\end{array}$} \\
\hline & 1970 & 2000 & 2015 & 2030 & 2050 & $\begin{array}{l}1970- \\
2000\end{array}$ & $\begin{array}{l}2000- \\
2030\end{array}$ & $\begin{array}{l}2030- \\
2050\end{array}$ & $\begin{array}{l}2000- \\
2050\end{array}$ \\
\hline Mundo & 3692 & 6071 & 7197 & 8130 & 8919 & & & & \\
\hline Países em desenvolvimento & 2603 & 4731 & 5802 & 6709 & 7509 & 2,0 & 1,2 & 0,6 & 0,9 \\
\hline África Subsariana & 262 & 607 & 853 & 1134 & 1509 & 2,9 & 2,1 & 1,4 & 1,8 \\
\hline Leste / Norte da África & 183 & 392 & 521 & 643 & 774 & 2,9 & 2,1 & 1,4 & 1,8 \\
\hline América Latina e Caribe & 281 & 515 & 623 & 705 & 762 & 2,0 & 1,1 & 0,4 & 0,8 \\
\hline Sul da Ásia & 708 & 1340 & 1685 & 1972 & 2208 & 2,2 & 1,3 & 0,6 & 1,0 \\
\hline Leste da Ásia & 1169 & 1877 & 2119 & 2256 & 2256 & 1,5 & 0,6 & 0,0 & 0,4 \\
\hline Países industriais & 727 & 905 & 965 & 1003 & 1019 & 0,7 & 0,3 & 0,1 & 0,2 \\
\hline Países em transição & 351 & 411 & 399 & 380 & 343 & 0,5 & $-0,3$ & $-0,5$ & $-0,4$ \\
\hline
\end{tabular}

Fonte: (ALEXANDRATOS et al., 2006 p.16)

Isso deverá acontecer devido ao nível mundial de natalidade que diminuirá de 2,83 filhos por mulher (1995-2000) para 2,02 de 2045-2050 (tabela 17) e a expectativa de vida que aumentará de 65 para 74 anos (tabela 16). E como consequência da redução esperada da natalidade, a taxa de crescimento anual da população deverá cair de 1,35\% ao ano em 1995-2000 para 0,33\% ao ano em 2045-2050. (ONU, 2003 p.1). 
Tabela 16: Expectativa de vida mundial e projetada

\begin{tabular}{lcc}
\hline Principais áreas & $1995-2000$ & $2045-2050$ \\
\hline Mundo & 64,6 & 74,3 \\
Regiões mais desenvolvidas & 74,8 & 81,6 \\
Regiões menos desenvolvidas & 62,5 & 73,1 \\
Países menos desenvolvidos & 48,7 & 66,4 \\
Outros países menos desenvolvidos & 65,4 & 75,1 \\
África & 50,0 & 64,9 \\
Ásia & 65,7 & 76,0 \\
América Latina e Caribe & 69,4 & 78,5 \\
Europa & 73,2 & 80,5 \\
América do Norte & 76,4 & 81,8 \\
Oceania & 73,2 & 80,9 \\
\hline
\end{tabular}

Fonte: (ONU, 2003 p.4)

Tabela 17: Natalidade mundial estimada e projetada

2045-2050

\begin{tabular}{lccccc} 
Principais áreas & $1995-2000$ & Baixo & Médio & Alto & Constante \\
\hline Mundo & 2,83 & 1,54 & 2,02 & 2,50 & 3,83 \\
Regiões mais desenvolvidas & 1,58 & 1,35 & 1,85 & 2,35 & 1,70 \\
Regiões menos desenvolvidas & 3,11 & 1,56 & 2,04 & 2,52 & 4,02 \\
Países menos desenvolvidos & 5,46 & 2,00 & 2,47 & 2,95 & 5,84 \\
Outros países menos desenvolvidos & 2,79 & 1,40 & 1,90 & 2,39 & 3,42 \\
África & 5,22 & 1,92 & 2,40 & 2,88 & 5,75 \\
Ásia & 2,72 & 1,42 & 1,91 & 2,41 & 3,41 \\
América Latina e Caribe & 2,72 & 1,36 & 1,86 & 2,36 & 2,94 \\
Europa & 1,42 & 1,34 & 1,84 & 2,34 & 1,45 \\
América do Norte & 2,01 & 1,35 & 1,85 & 2,35 & 2,02 \\
Oceania & 2,45 & 1,41 & 1,92 & 2,42 & 3,12 \\
\hline
\end{tabular}

Fonte: (ONU, 2003 p.4)

Apesar dessa queda drástica projetada na taxa de crescimento, os incrementos anuais absolutos continuam a ser consideráveis. Setenta e nove milhões de pessoas foram acrescentadas à população mundial a cada ano na segunda metade da década de 1990 e a previsão é de que o número permanecerá em mais de 50 milhões por ano até meados de 2030. Porém rápidos declínios após 2035 deverão reduzir o incremento anual para 26 milhões em 2050. Praticamente todos esses aumentos serão identificados nos países em desenvolvimento. No outro extremo, a população da África Sub-Sahariana continuará a crescer a 1,2\% ao ano no mesmo período (2045-50). Em 2050, 18 milhões dos 26 milhões adicionados anualmente à população mundial 
se concentrará na África Sub-Sahariana. Alguns países, a maioria na África, têm projeções demográficas que sugerem que as suas populações em 2050 serão multiplicadas. Esta perspectiva traz consigo uma importante questão relacionada ao consumo de alimentos e nutrição em um futuro previsível. (ALEXANDRATOS et al., 2006 p.16).

A diferença de trajetórias de crescimento entre as regiões mais desenvolvidas e as menos desenvolvidas é o produto de seus níveis atuais de natalidade. Embora existam diferenças consideráveis na natalidade entre os países das regiões mais desenvolvidas, em praticamente todos eles a natalidade possui atualmente um nível abaixo de substituição (ou seja, abaixo de 2,1 filhos por mulher) e, embora seja projetado para subir um pouco no futuro, permanecerá abaixo do nível de substituição até 2050. Assim, para as regiões mais desenvolvidas como um todo, a natalidade deverá diminuir a partir de 1,58 filhos por mulher em 1995-2000 para 1,56 crianças por mulher em 2005-2010 e, em seguida, subirá lentamente a 1,85 filhos por mulher em 2045-2050. (ONU, 2003 p.1).

Por meio dessa projeção é possível identificar que o crescimento está diminuindo, apesar da base populacional ser maior. E o crescimento projetado após 2040 ocorrerá não porque o nível de natalidade sofrerá crescimento, mas porque haverá um maior número de pessoas em idade de procriação. De acordo com as estimativas analisadas, o crescimento populacional estará estabilizado em 2040, de forma que as pessoas só terão o número necessário de fillhos para substituí-las. (HAKKERT, 2011). Como a população continua a crescer, torna-se necessária a ampliação da capacidade agropecuária. Caso contrário, em algumas décadas, a fome poderá ser um problema político, econômico e numérico.

Analisando a influência comportamental na forma como a humanidade define prioridades de consumo, Darwin \& Garcia (BALATSKY; BALATSKY; BORYSOV, 2015) identificaram o comportamento humano como funções de um sistema, o qual é um produto do desenvolvimento histórico juntamente com suas características, criado ao longo do tempo na história da cultura humana. As transformações ocorridas nesse sistema são incorporadas aos seres humanos, as quais podem incluir sabedoria de vida relacionada ao meio que os rodeia e ao mesmo tempo estruturas e funções de adaptação a novos formatos de sociedades. Dessa forma, é possível entender que o ciclo de vida e seus padrões atuam em um processo que sofre mudanças estruturais e funcionais, o qual muitas vezes podem provocar alterações que influenciam o curso normal do comportamento. (DARWIN; GARCIA, 2009 p.70-84) 
Além disso, o comportamento humano sofre alterações ao longo do tempo devido a impulsos gerados por transformações sociais, culturais e econômicas. (DARWIN; GARCIA, 2009 p.75; LORENZ, 1974 p.34) Isso pode ser identificado, por exemplo, nas alterações nos níveis de consumo, que consequentemente trouxeram novos auges de consumo de recursos do planeta. É possível afirmar que o rápido crescimento populacional em todo o mundo causa uma necessidade grande de bens de consumo e a cada momento, surgem novos modelos, novas tecnologias, novos produtos, aumentando o consumismo (DARWIN; GARCIA, 2009 p.76; LORENZ, 1974 p.37).

\begin{abstract}
"O consumismo é um processo eticamente condenável, pois faz com que as pessoas comprem mais do que realmente necessitam. Por meio de complexos sistemas de propaganda, que envolvem sutilezas psicológicas e recursos espetaculares, industriais e produtores induzem a população a adquirir sempre os novos modelos de carros, geladeiras, relógios, calculadoras e outras utilidades, lançando fora o que já possuem". (SUTCLIFFE; HOOPER; HOWELL, 2008)
\end{abstract}

O consumo excessivo, por sua vez, gera desperdício. Há uma diferença entre o consumo por necessidade e aquele de significado simbólico. O consumo de significado simbólico é aquele pelo qual o consumidor tende a desejar um novo modelo de aparelho ou produto sem ter em vista a sua real finalidade, mas somente pelo fato de que o produto possui um novo atributo. Como exemplo, pode-se ilustrar um aparelho celular que tem como função principal efetuar e receber ligações. No entanto, existem diversos modelos, que a cada dia estão mais modernos, mais avançados e que desempenham não só a sua função principal, mas também inúmeras outras. Juntamente com a mídia e a publicidade, as empresas "criam necessidade" desses bens, induzindo o cidadão ao consumo, muitas vezes, desnecessário. O consumismo exagerado, somado ao aumento populacional no globo terrestre, faz com que existam cada vez mais indústrias, que por sua vez consomem grande quantidade de energia e matérias-primas, gerando grandes quantidades de resíduos, causando enormes impactos ambientais.

Por outro lado, o consumo se tornou uma fórmula de bem estar e de prazer, o qual pode gerar uma vida com maior nível de felicidade, e contribuir para uma vida mais longa. (COSTA; IGNÁCIO, 2011 p.5).

\title{
2.6.12 A Economia de Mercado
}

Um dos primeiros pensadores econômicos ao se preocupar com a alimentação, trouxe atenção a um conceito que se tornou fundamental nas discussões econômicas: a escassez. O conceito de 
escassez foi identificado na Era da Razão (figura 24) - época marcada por mudanças políticas e descobertas tecnológicas que transformaram o modo de produção de bens. (KISHTAINY et al., 2013 p.50).

Figura 24: Linha do Tempo Econômica

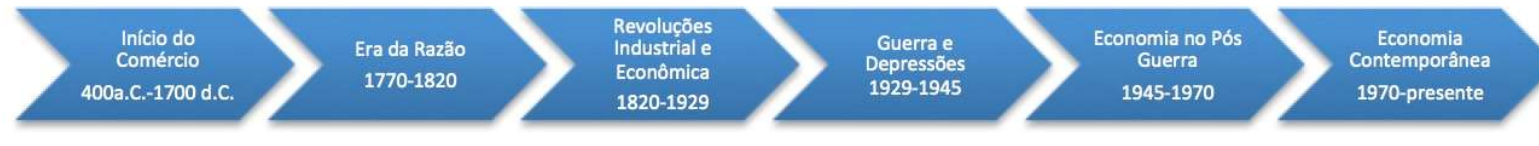

Fonte: (KISHTAINY et al., 2013)

Thomas Malthus (1766) introduziu o conceito de uma escassez geral no pensamento econômico clássico. De acordo com Malthus, leis naturais definiam que o crescimento da população é sempre substancialmente mais rápido do que o crescimento da produção agrícola, e isso implicaria em um forte e constante controle, operando na dificuldade de subsistência da população. De modo mais geral, a escassez malthusiana denota a ideia de que os recursos naturais essenciais têm um limite físico finito. Isso implica na existência de limites para o crescimento econômico (ideia que iria de encontro com o pensamento desenvolvido no século XVII de que uma grande população produz sempre benefícios a economia). Anos mais tarde, Ricardo (1817) deu uma nova interpretação econômica à escassez, que se refere à qualidade decrescente de terra: terra, como um recurso natural, a terra está prontamente disponível, mas sua qualidade apresenta declínio com o aumento da produção. Ao longo do tempo, a distinção entre a escassez Malthusiana e Ricardiana perdeu sua relevância. A economia neoclássica adotou uma noção mais abstrata de escassez que não se refere especificamente aos recursos naturais, mas é baseado de forma geral em desejos e preferências humanas. (BAUMGÄRTNER et al., 2006 p.488-489; STIGLITZ, 1974).

Na segunda metade do século 20, houve várias tentativas de revitalizar a discussão sobre o conceito de escassez econômica, referindo-se às considerações econômicas clássicas, bem como às ciências naturais tais como a termodinâmica ou ecologia (BARBIER, 1989;1999). Contribuições pioneiras foram feitas, por exemplo, por BARNETT; MORSE (1963), BOULDING (1966), GEORGESCU-ROEGEN (1986), MEADOWS, D. H. et al. (1972), e DALY (1991). Todos esses se referem, em algum sentido, ao conceito malthusiano da escassez geral da natureza. 
DALY (1991) introduz a ideia de que há dois tipos diferentes de escassez: a "escassez absoluta", que ele distingue de "escassez relativa". A diferença entre a escassez "relativa" e "absoluta" foi abordada por diferentes autores. (BARBIER, 1989; BARBIER et al., 1995; SAHU; NAYAK, 1994; UNDERWOOD; KING, 1989). A característica que as difere é que a escassez relativa busca a alocação ótima dos recursos naturais (através de uma economia ambiental) e a escassez absoluta se preocupa com a distribuição justa dos recursos naturais (através de uma economia ecológica). (SAHU; NAYAK, 1994; UNDERWOOD; KING, 1989).

Segundo BAUMGÄRTNER et al. (2008 p.384-385), a economia ecológica é caracterizada com base na atuação da economia de forma sustentável. Uma segunda característica é que a economia ecológica não é impulsionada somente por um interesse cognitivo, ou seja, entender e explicar o mundo e seus recursos como são, mas também por um interesse de gerir o mundo com base em uma ideia de como deveria ser ou ações ideais. (BAUMGÄRTNER et al., 2006; BOCKSTAEL et al., 1995 p.144).

No entanto, para alguns a sustentabilidade relacionada à economia não perdura - mas o desenvolvimento econômico é o pilar sustentador de uma sociedade. (BOCKSTAEL et al., 1995) Simon Kuznets (1901-1985) foi um economista nascido na Ucrânia, ganhador do Prêmio Nobel de 1971, que fez importantes contribuições aos estudos macroeconômicos. Originalmente, a "Curva de Kuznets" foi uma representação gráfica elaborada para expressar a hipótese de que o aumento da desigualdade de renda é uma tendência natural dos primeiros ciclos do desenvolvimento, mas que se reverte com o passar do tempo. A Curva Ambiental de Kuznets (CAK) tem a mesma forma do "U invertido", mas é aplicada para a área ambiental. A CAK tem sido usada pelas pessoas que defendem o desenvolvimento econômico como uma prioridade em relação ao meio ambiente. (AL-MULALI et al., 2015; BAGLIANI; BRAVO; DALMAZZONE, 2008).

A ideia básica da CAK é que o desenvolvimento só causa grandes problemas ambientais em suas etapas iniciais e à partir de certo ponto, o aumento da renda per capita e da educação levaria à uma menor degradação ambiental e com isso, altas doses de desenvolvimento seriam úteis não só para reduzir as desigualdades sociais, mas também para salvar a natureza. (DIETZ, S.; ADGER, 2003). Embora haja pesquisas realizadas no tema, a CAK ainda não possui comprovação efetiva. 
Pelos dados já abordados dessa pesquisa, a produção e o consumo de alimentos sofre constantes aumentos e a degradação ambiental continua a ser um item de extrema preocupação. (BROWN, J. H. et al., 2014; DIETZ, S.; ADGER, 2003). Embora haja uma particularidade da economia que visa o uso de recursos em benefício da sociedade, há uma outra particularidade que visa o uso de recursos de forma sustentável. (CHANG et al., 2013; DRECHSLER et al., 2007; EDWARDS; ABIVARDI, 1998).

Por outro lado, é importante considerar as teorias de crescimento e desenvolvimento econômico como impulsionadoras da produção pecuária bovina de corte. Segundo BRUE (2005), o crescimento econômico, considerado o aumento da produção real de um país (PIB) que ocorre durante determinado tempo, é resultado (1) da maior quantidade de recursos naturais, (2) melhorias na qualidade dos recursos e (3) avanços tecnológicos que impulsionam a produtividade. O PIB real per capita de um país, ou seja, o padrão de vida - aumenta quando sua produção real aumenta mais rapidamente do que sua população. E o desenvolvimento econômico é o processo pelo qual uma nação melhora seu padrão de vida durante determinado período.

A dependência crescente de alimentos concentrados na produção animal, juntamente com a crescente liberalização do comércio e melhoria da infraestrutura de transporte e tecnologia, resultou em um aumento concomitante no comércio de alimentos. A maioria da comida consumida em todo o mundo é cultivada de forma local. Onde não há produção local suficiente para atender a demanda, o comércio global tem sido fundamental para preencher a lacuna. A escala de alimentos e comércio agrícola hoje não tem precedentes. Em termos reais, o valor dos fluxos internacionais aumentou em torno de cinco vezes nos últimos 50 anos, refletindo as tendências globais no volume global do comércio. No entanto, essa expansão foi desigualmente distribuída entre as regiões. Durante grande parte do período, os países de alta renda ultrapassaram as regiões em desenvolvimento, embora vários desses últimos têm vantagens comparativas em alimentos e produção agrícola. (ODEGARD, INGRID YM RUTH, 2011).

As taxas de crescimento divergentes no setor agrícola podem ser observadas em países individuais e grupos de países, dependendo de mudanças em suas posições comerciais agrícolas. Em geral, as taxas de crescimento da produção na maioria das regiões em desenvolvimento têm sido um pouco menor do que as de demanda, assim como as importações agrícolas desses países têm crescido mais rapidamente do que as exportações, erodindo gradualmente os seus excedentes tradicionais no comércio agrícola. (FAO, 2013 p.148). 
Tradicionalmente, os países em desenvolvimento têm sido importadores de produtos provenientes da agricultura temperada - especialmente cereais - exportadores líquidos de arroz e importadores líquidos de trigo e cereais secundários. O trigo é o maior item da cesta de alimentos que provoca déficit nos países em desenvolvimento. Entre 1970 e 2010, mais da metade do incremento no consumo de trigo foi recebida pelo aumento das importações de trigo, e vários países tornaram-se totalmente dependentes de importações de trigo. (FAO, 2013 p.150).

Ao mesmo tempo, os países em desenvolvimento exportadores líquidos têm aumentado as suas exportações nas últimas décadas. Índia e China se juntaram aos exportadores líquidos tradicionais da América do Sul, como Brasil e Argentina, e os exportadores de arroz da Ásia, incluindo a Tailândia. Índia e China se tornaram exportadores líquidos de outros cereais. As exportações líquidas de grãos da China cresceram em meados dos anos 1980, e a Índia tem sido um exportador líquido ocasional de trigo desde 2000. (FAO, 2013 p.150). As exportações mundiais de café, chá, cacau e especiarias quase triplicaram entre 2000 e 2010, de US\$29 bilhões em 2000 para US\$ 79 bilhões em 2010. O café, de forma isolada, foi responsável por cerca de um terço dessa expansão. Alemanha e Brasil são os principais países entre importadores e exportadores, respectivamente. (FAO, 2013 p.154).

O déficit líquido global de alimentos e comércio de produtos agrícolas de países em desenvolvimento, como um grupo, seria muito mais profundo se não fosse o desempenho excepcional de alguns emergentes agroexportadores, como o Brasil, que adquiriu uma posição proeminente como um exportador de oleaginosas e produtos derivados do gado. As importações em grande escala de produtos agrícolas na última década, especialmente matérias-primas e commodities primárias da China, também têm gerado um impacto sobre essa tendência. (FAO, 2013 p.152).

Frutas e legumes têm sido responsáveis por aumentos consistentes na posição como exportador líquido de muitos países. Este agregado de produtos tornou-se o mais importante em termos de valor. Ao longo da década 2000-2010, o setor de frutas e vegetais cresceu em mais de $11 \%$ ao ano, a nível mundial, quase $20 \%$ na África e em 17\% na Ásia, mas a Europa continua a ser o maior exportador. O comércio de milho e soja, duas colheitas de alimentação primárias, tem crescido em $2,8 \%$ e 7,0\% ao ano na última década; essas taxas são mais elevadas do que qualquer coisa vista sobre as duas décadas anteriores. (FAO, 2013 p.152). 
O comércio internacional de óleos vegetais também tem crescido rapidamente, em 17\% ao ano. Países asiáticos responderam por mais da metade das exportações mundiais em 2010, por causa do rápido aumento das exportações líquidas provenientes de países como a Malásia e a Indonésia. As importações na China têm ganhado muito destaque, e Argentina e Brasil continuam a ser os principais exportadores da América Latina. (FAO, 2013 p.152).

Como um todo, tradicionalmente grandes excedentes comerciais de açúcar dos países em desenvolvimento diminuíram rapidamente desde o início de 1990, uma vez que vários países em desenvolvimento tornaram-se grandes importadores. Essa retração reflete também o apoio interno e proteção comercial em alguns dos principais países importadores de açúcar. Globalmente, as exportações de açúcar e mel cresceram 11\% na última década. A maior parte deste crescimento foi impulsionado pelas Américas e Ásia. As exportações de oleaginosas também cresceram muito rapidamente, em mais de 15\% ao ano. (FAO, 2013 p.154).

Em muitas economias emergentes, a agricultura tem gradualmente se movido para o aumento da comercialização de alimentos de alto valor, tais como aves, suínos e peixes. Para aves e peixes, a expansão do comércio tem superado em muito o consumo interno. $\mathrm{O}$ valor agregado das exportações líquidas da pesca provenientes de países em desenvolvimento já ultrapassa o valor total dos pilares tradicionais de exportações agrícolas, como café, chá, cacau, bananas e açúcar. (FAO, 2013 p.154).

O comércio de carnes e subprodutos, enquanto apenas um décimo do volume do comércio de alimentação, também está crescendo muito rapidamente, particularmente para não ruminantes. Durante a última década, o comércio mundial de carne de porco e carne de frango cresceu a taxas anuais de 5,6\% e 6,8\%, respectivamente, que é aproximadamente igual a uma duplicação do volume de comércio a cada 10-12 anos. O comércio como uma percentagem do total da produção também está crescendo rapidamente para a carne suína e aves, tendo duplicado nas últimas duas décadas para cerca de 10\% para ambos os setores (FAO, 2013 p.156).

Segundo FAO (2013 p.156), a expansão do mercado de carne provavelmente continuará até pelo menos 2050. Contudo, apesar de um aumento do consumo de carne e do comércio em geral, o crescimento favorável de renda e a abundância de proteína de alta qualidade indicam que está mudando a relação entre a produção de carne e o ambiente. $\mathrm{O}$ rápido crescimento no 
comércio de alimentos para animais e carne cortou as ligações tradicionais entre pecuária e a base de recursos locais. Por exemplo, a produção de nutrientes desde a produção intensiva de animais muitas vezes excede a capacidade de absorção da área circundante, e aumentando os custos de transporte e distâncias significa que esses nutrientes, muitas vezes não são devolvidos para a terra de forma produtiva. Ao mesmo tempo, aumentar a produção de alimentos concentrados leva seu próprio pedágio ambiental através do uso e da perda de fertilizantes e pesticidas, o uso dos escassos recursos hídricos, ou conversão de terras de grande valor ecológico. (STEINFELD et al., 2006).

Para o importador do produto de carne acabada, esses efeitos ambientais são obscurecidos por um sistema de produção e comércio, que subavalia os recursos ambientais e subestima o potencial dano ambiental inerente ao processo de produção. Porém esses efeitos podem ser significativos. Um estudo estima que os custos externos da produção agrícola dos EUA (por exemplo, o custo dos danos às pessoas e aos ecossistemas, o controle do governo e processos de limpeza não suportados pelos produtores ou consumidores) são no total entre US\$ 9,4 e 20,6 bilhões por ano (TILMAN et al., 2002). Quantificar o link real, mas escondido entre o consumo e a produção é uma questão relevante para a política que tem sido estudada por outros bens intensivos em recursos naturais. Por exemplo, TEGTMEIER; DUFFY (2004) indicaram que as externalidades econômicas e ambientais do uso de água geralmente não são incluídas no preço pago pelos consumidores estrangeiros.

A acrescida integração comercial tem proporcionado aos consumidores uma maior variedade de produtos a preços mais baixos, produzidos através de cadeias de valor cada vez mais complexas. (FAO, 2013 p.154)

Figura 25: Comparação do PIB Agronegócio com o PIB Total Brasileiro

\section{Evoluçăo do PIB de Agronegócios e PIB Total Brasileiro (\%)}

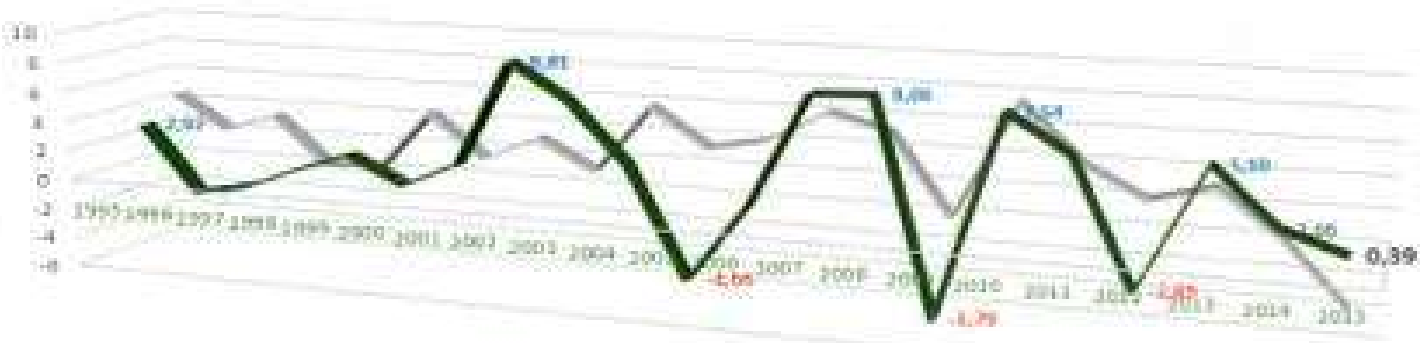

Total PIB Agro PIB

Fonte: (CEPEA/ESALQ, 2015) 
Na figura 26, é possível visualizar a evolução do chamado "PIB do agronegócio" (que mede a geração de riquezas em todas as cadeias do setor agropecuário, desde a produção de insumos, passando pela produção nas fazendas até a chegada às indústrias de alimentos) e o seu ganho de importância no decorrer do tempo (indicados na figura 25).

Figura 26: Participação do Agronegócio no PIB Brasileiro

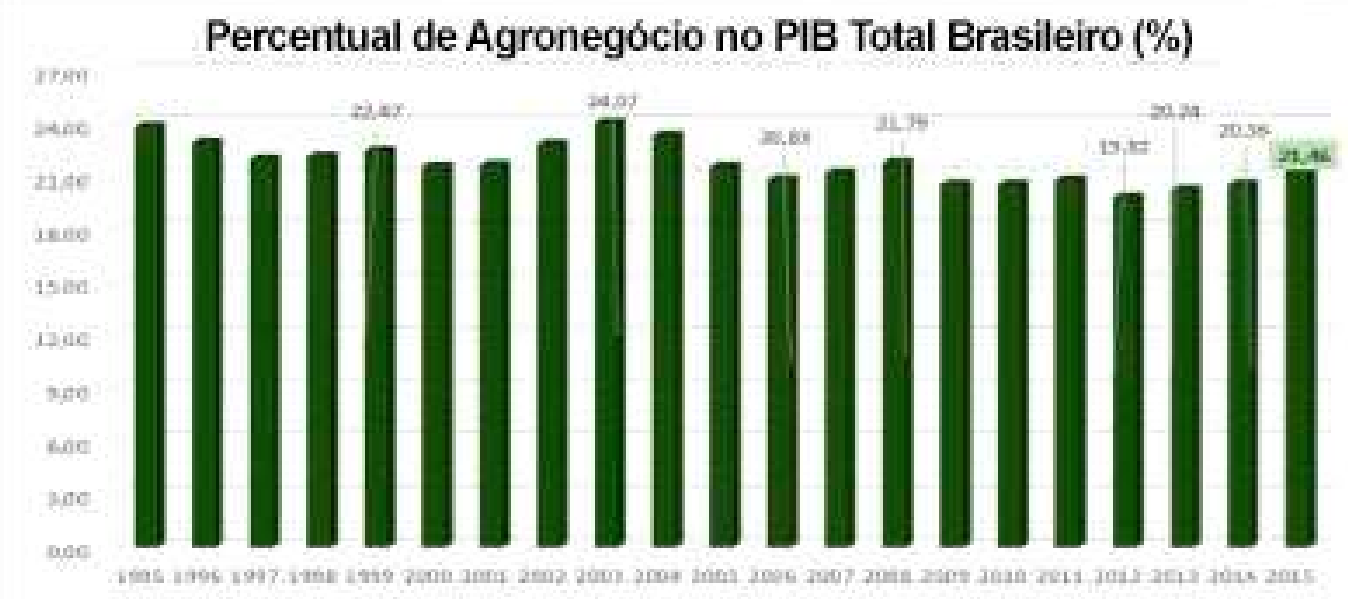

Fonte: (CEPEA/ESALQ, 2015)

Nas figuras 27 e 28 é possível identificar a constante participação do agronegócio no PIB Brasileiro, dividido em insumos agropecuários (12\%), produção agropecuária (30\%), agroindústria (28\%) e serviços de distribuição (30\%).

Figura 27: Participação de cada segmento no PIB do Agronegócio Brasileiro

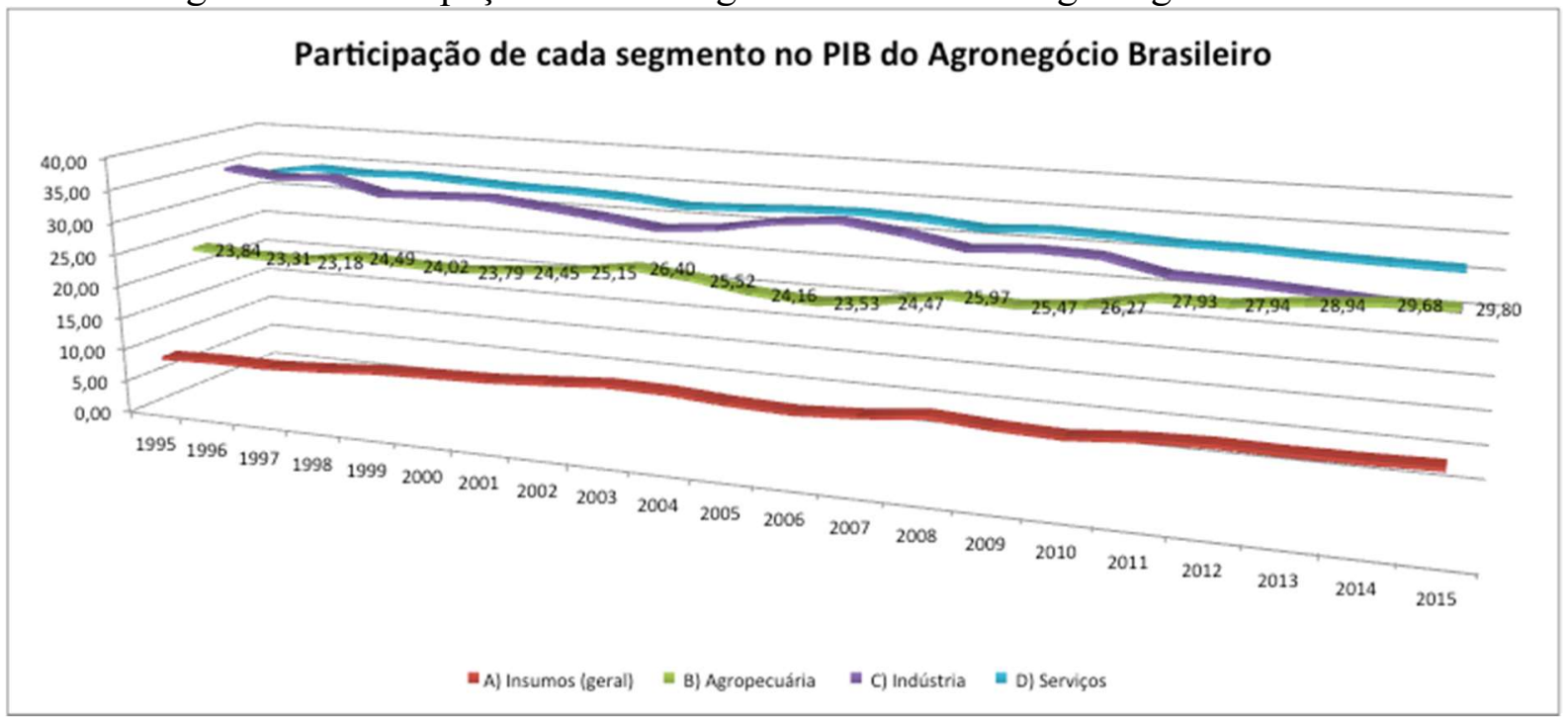

Fonte: (CEPEA/ESALQ, 2015) 
Figura 28: Participação da Pecuária no PIB do Agronegócio Brasileiro

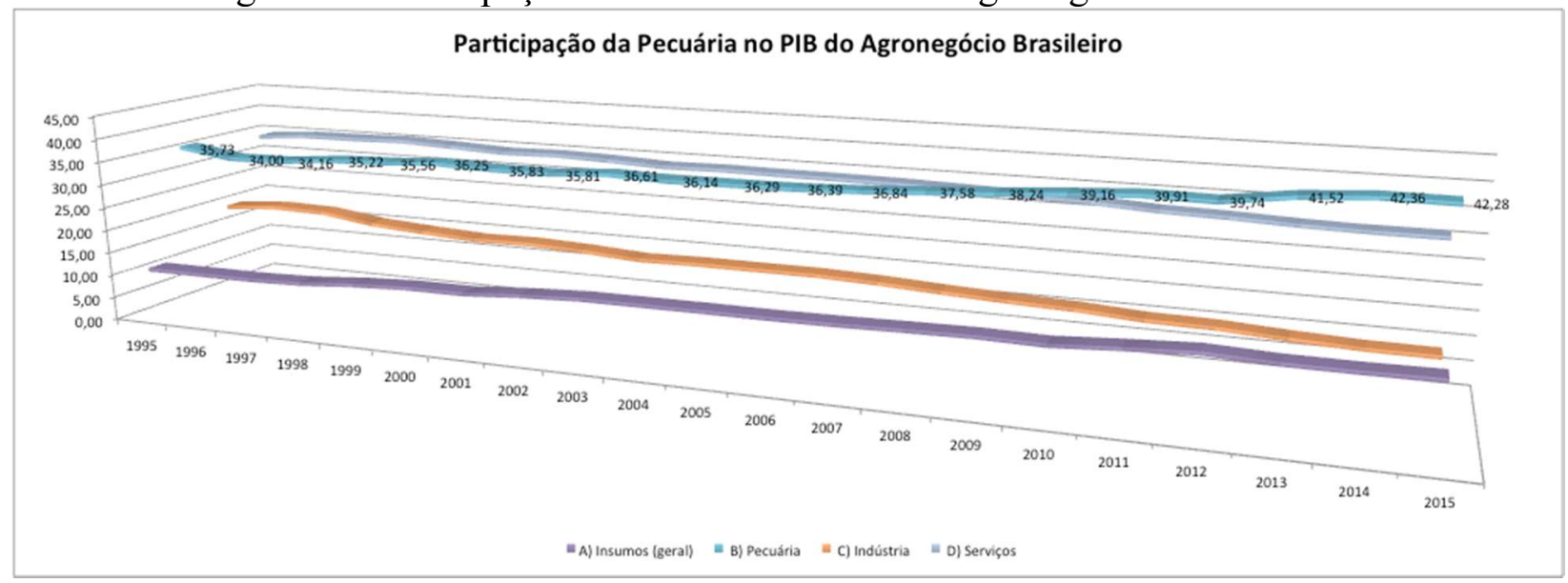

De acordo com CEPEA/ESALQ (2015), o Produto Interno Bruto (PIB) da pecuária bovina de corte é o maior entre as cinco cadeias produtivas do agronegócio brasileiro. É possível perceber na figura 26 o contínuo crescimento da produção pecuária ao longo dos anos. Em 2015, os segmentos de insumos, produção primária, processamento e serviços movimentaram cerca de $\mathrm{R} \$ 188$ milhões, mais do que o dobro dos R \$ 91,4 bilhões da cadeia da soja.

Segundo CNA (2016), a expectativa é de que a pecuária brasileira continue competitiva no mercado externo, considerando especialmente a exportação de embarques diretos para a China e de carne in natura para os Estados Unidos.

\subsubsection{O Desenvolvimento Tecnológico}

Para LORENZ (1974), os sábios da humanidade reconheceram que não era bom para o homem alcançar facilmente a satisfação de sua aspiração instintiva (obter o prazer e evitar o sofrimento) e por isso, os homens descobriram que graças a uma combinação engenhosa (tecnologia), é possível aumentar o prazer e, através de sua constante modificação, evitar que esse prazer seja desgastado pelo hábito.

A ecologia humana se transforma com maior rapidez do que qualquer ser vivo. A velocidade disso é definida pelo progresso de sua tecnologia, que está em alta velocidade e em progressão geométrica. Mediante o exposto, o homem é obrigado a provocar modificações profundas, levando até mesmo a ruína do ambiente em que vive, levando ao esgotamento de recursos do 
planeta. O sentimento é de que o homem só irá se aperceber que está provocando um vandalismo ecológico quando esses produzirem consequências econômicas. (LORENZ, 1974).

Para que haja uma utilização mais sustentável da base de recursos limitada, são necessárias melhorias substanciais na gestão e uso da terra, água e insumos. Os investimentos contínuos são necessários em tecnologias melhoradas para reduzir as perdas na biodiversidade e limitar as emissões de carbono provenientes da agricultura. Desenvolvimento e transferência de tecnologia por si só não irão eliminar as disparidades de rendimento ou reduzir o desperdício ou perdas pós-colheita. Os agricultores estão propensos a adotar tecnologias se houver sólidos incentivos para fazê-lo: isso exige bom funcionamento dos mercados de entrada e saída, a melhoria da infra-estrutura, e melhores ferramentas de finanças e gestão de risco. (ALEXANDRATOS et al., 2006; DAY et al., 2014; SUTTON et al., 2013).

Para ajudar a reverter o caminho insustentável que a sociedade humana iniciou no que diz respeito à utilização de bens e serviços do ecossistema algumas estratégias foram desenvolvidas para ajudar a mover a sociedade humana em direção à sustentabilidade. Uma dessas estratégias é a tecnologia sustentável. Sem uma mudança fundamental na maneira como a humanidade mede o bem-estar, a eficácia das tecnologias sustentáveis não será capaz de competir com alternativas não-sustentáveis. (BLIGNAUT; ARONSON; DE GROOT, 2014).

A tecnologia pode influir na mudança ambiental por identificar novas formas de descobrir e explorar recursos naturais. Além disso, a tecnologia pode aumentar ou diminuir o impacto da atividade humana sobre o meio ambiente.(MORSE; VOGIATZAKIS, 2014).

Melhorias de eficiência são muitas vezes apontadas como meios eficazes para a redução do consumo de recursos. Para muitos, e talvez, em particular, para engenheiros, a ideia de que as reduções no consumo de recursos podem ser alcançadas através de soluções baseadas em tecnologia é especialmente atraente. (QUIRINO et al., 1999 p.109). Como tal, a melhoria na eficiência é frequentemente citada como um componente crítico de engenharia verde. Porém a concentração em melhorias de eficiência certamente tem foco em benefícios econômicos e sociais e de forma secundária em redução no consumo de recursos. E apesar dos avanços tecnológicos, fatores como o crescimento da população, aumento do poder aquisitivo, mudança no comportamento do consumidor, e outros fatores, favorecem o aumento do consumo de recursos. (BLAIR; SOBAL, 2006; DAHMUS, 2014 p.883-884). 
Por outro lado, a mudança tecnológica encarada como um fator que contribui para a eficiência encontra um trade-off: na visão do engenheiro, a eficácia pode se basear na redução do consumo de recursos e na visão do economista a melhoria de eficiência é encarada como potencial aumento do consumo de recursos. (HERRING, 1999). Para muitos, e talvez, em particular, para os engenheiros, a ideia de que a redução no consumo de recursos e, portanto, redução dos impactos ambientais associados ao consumo de recursos, pode ser alcançada através de soluções baseadas em tecnologia é especialmente atraente. (DAHMUS, 2014).

Embora tenham se realizado com sucesso melhorias em níveis de eficiência em produto e processo ao longo dos séculos, ainda assim, não têm ocorrido na mesma velocidade reduções no nível de consumo de recursos naturais. Em vez disso, impulsionado pelo crescimento da população, aumento do poder aquisitivo, mudança no comportamento do consumidor, e outros fatores, o consumo de recursos continua a aumentar. Em contrapartida, a divergência entre a visão do engenheiro (de que as melhorias da eficiência são vistas como a redução do consumo de recursos) e a visão do economista (de que as melhorias de eficiência são vistas como potencial aumentando do consumo de recursos) persiste. (HERRING, 1999;2006; HERRING; SORRELL; ELLIOTT, 2009; SMIL, 2005).

O setor agropecuário brasileiro teve de adaptar-se às novas exigências do comércio mundial devido aos avanços tecnológicos e crescimento do mercado de carne a nível global, principalmente em relação à melhor qualidade dos produtos e segurança alimentar, por meio de certificações sanitárias e de rastreabilidade. Algumas tendências verificadas no mercado de carne brasileiro, como a concorrência a nível global e transformações da organização da produção, resultaram numa evolução tecnológica que viabilizou o uso de Pesquisa \& Desenvolvimento como ferramenta de impulso ao crescimento do mercado nacional. A implementação tecnológica ocorrida nos últimos anos, especialmente para as fases de cria, a qual inclui os programas de melhoramento genético animal e os de cruzamento industrial, têm contribuído para elevar a produtividade do setor bovino de corte. (SCARE; ANTOLINI; MIRANDOLA, 2014). Vários estudos (ALBUQUERQUE; MEYER, 2005; BRITO; FRIES, 1994; FRIES; SCHENKEL, 1993; LOPES, P. et al., 1995; MARTINS et al., 1997; TORRES JUNIOR et al., 1997) têm sido desenvolvidos com o intuito de que desenvolvimento, adaptações e comparações de métodos sejam realizados visando o progresso de diversos agrupamentos genéticos. 
Segundo BARROS; HAUSKNECHT (2005), o progresso tecnológico exerce papel fundamental na elevação do bem-estar da sociedade e tem sido encarado como a única forma de fazer com que os fatores de produção ampliem a capacidade de geração de renda, criando novas formas de combinação de recursos, permitindo o uso de insumos antes nunca utilizados, elevando a produtividade do trabalho e dos recursos envolvidos. De acordo com BARROS; HAUSKNECHT (2005), por meio do desenvolvimento tecnológico, foi possível alcançar tanto a elevação da produtividade como a estabilidade na oferta de alimentos, livrando a humanidade de crises de desabastecimento e aumentos drásticos de preços.

Em um dos estudos desenvolvidos para compreender a produtividade do setor agropecuário nos Estados Unidos, Cochrane (1993) in SHEPHERD (1981) identificou que agricultores investiam em suas nas atividades sem obter acréscimos significativos em longo prazo e por isso investigou a diferença de produtividade em três grupos distintos de agricultores: (1) os modernos e dispostos a adotar novas tecnologias; (2) os que aguardam resultados para adoção de uma nova tecnologia e (3) os que não fazem uso de tecnologia. Ao longo do estudo foi descoberto que o grupo 1 apresenta maior produtividade, porém sendo um pequeno grupo, sua pequena quantidade de produção é insuficiente para reduzir os preços praticados no mercado. O grupo 2, ao ver o resultado do grupo 1, adota a nova tecnologia, aumenta a produção e consequentemente a oferta de mercado aumenta e com isso os preços passam a cair progressivamente. O grupo 3 que não investe em tecnologia, passa a manter o seu mesmo custo unitário, mas uma vez que se sentem impelidos a reduzir o preço, passam a não cobrir os custos de produção. O modelo de Cochrane (1993) indica que o aumento de produtividade advindo do progresso tecnológico e dos ganhos em escala são as únicas formas de assegurar a redução sistemática dos custos médios, garantindo a permanência da produção e em longo prazo, o crescimento da agropecuária.

No quadro 2, é possível identificar algumas das tecnologias que podem ser aplicadas para o aumento da produtividade na agropecuária. Segundo BARROS; HAUSKNECHT (2005), para a elevação da produção por animal, o melhoramento genético representa o passo fundamental, o qual envolve tecnologias de inseminação, transferência de embrião, fertilização in vitro e etc. O controle sanitário e melhoramento da nutrição complementam as possibilidades de expansão da produção por animal. Um dos fatores fundamentais na nutrição dos animais foi o alto incremento na mineralização do rebanho brasileiro, considerado um solo com baixa fertilidade 
- característica de um clima tropical. Além disso, a prática de fornecer alimentação suplementar possibilitou o aproveitamento de produtos originando subprodutos do processamento de matéria prima em semi-confinamento e melhoramento genético e nutrição em ambientes de confinamento.

Quadro 2: Tecnologia em Pecuária de Corte

Tecnologias que elevam a produção por animal

Melhoramento genético

Sanidade

Mineralização

Semiconfinamento

Confinamento
Tecnologias que elevam a produção por área

Pastejo rotacionado

Adubação

Irrigação

Integração lavoura-pecuária

Fonte: (BARROS; HAUSKNECHT, 2005)

$\mathrm{O}$ conjunto de práticas que permite o aumento da produtividade por área envolve em boa medida, técnicas de manejo de pastagem, como por exemplo: pastejo rotacionado, a recuperação da fertilidade do solo, o manejo dos pastos cm adubação, irrigação e a integração lavoura-pecuária. Nesse conjunto de práticas, a agricultura e a pecuária se complementam, pois de um lado há a recuperação da fertilidade do solo e das pastagens realizadas pela agricultura e de outro lado, a necessidade de rotação de cultura na agricultura sugere que o pasto possa ser utilizado pela pecuária como elemento que reduz as dificuldades agronômicas advindas de plantios sucessivos de uma mesma cultura. (BARROS; HAUSKNECHT, 2005)

Nesse subtítulo foi verificado que a pecuária bovina de corte têm utilizado uma quantidade considerável de recursos naturais em sua produção e que isso tem gerado diferentes níveis de impactos ambientais. A seguir foi explicitado o consumo de carne bovina, juntamente com os impactos decorrentes dele e suas variáveis influenciadoras.

\subsection{O Consumo de Carne Bovina}

Para uma vida saudável é importante que se tenha uma dieta variada, equilibrada e moderada. Ou seja, além de se ingerir alimentos dos mais diversos tipos moderadamente, é necessário haver um equilíbrio entre eles. (VECCHIA; MAJEM, 2015). A formação dos hábitos alimentares pode ser influenciada por uma série de fatores: fisiológicos, psicológicos, socioculturais e econômicos. No entanto, para ajudar as pessoas a terem uma dieta com variedade, equilíbrio e moderação o Departamento de Agricultura dos EUA (USDA) desenvolveu, há quase duas décadas atrás, o Food Guide Pyramid ou Guia da Pirâmide 
Alimentar, que continha os elementos de uma dieta saudável. Essa pirâmide foi disseminada em escolas, na mídia, e até mesmo estampada em rótulos de alimentos. Porém, anos mais tarde, identificou-se que a informação incorporada na presente pirâmide não apontava o caminho para uma alimentação saudável, pois baseava-se em evidências científicas instáveis.

Figura 29: Pirâmide da Alimentação Saudável

\section{PIRÂMIDE DA ALIMENTAÇÃO SAUDÁVEL}

Departamento de Nutrição, Harvard School of Public Health

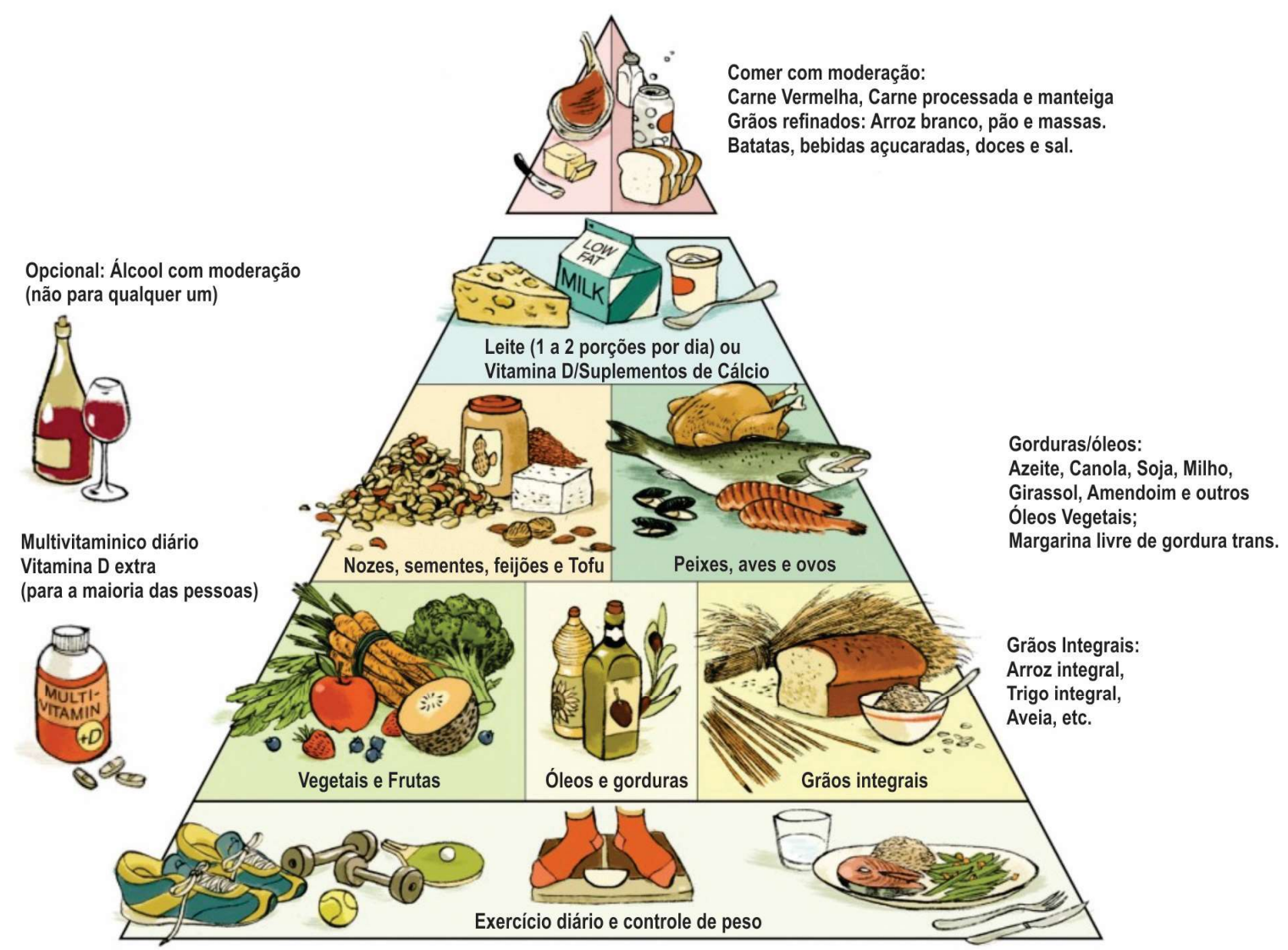

Fonte: (HARVARD, 2015)

Em 2005, o Guia da Pirâmide Alimentar foi substituído pela My Pyramid ou Minha Pirâmide, em que foram realizadas pequenas adaptações da versão original. Em 2011, My Pyramid foi substituído por My Plate ou Meu Prato, que utilizava símbolos mais simples e inteligíveis, porém, segundos críticos, deixava a desejar no quesito orientações para hábitos saudáveis. Como uma alternativa para o conselho de nutrição do USDA, membros do corpo docente da Escola Harvard de Saúde Pública elaboraram a Pirâmide da Alimentação Saudável (figura 29), que leva em consideração uma remodelagem na definição de uma alimentação saudável e a 
inclusão de uma rotina de exercícios físicos, acompanhado de hábitos de controle da alimentação. (HARVARD, 2015).

Embora sejam desenvolvidos métodos para controle e manutenção de hábitos saudáveis de alimentação, os índices indicam que a alimentação da população não segue parâmetros científicos. Um exemplo disso é que algumas pesquisas indicam que a população que vive em áreas rurais (ou região não urbanizada destinada a atividades de agricultura, pecuária, extrativismo, silvicultura ou conservação ambiental) tende a possuir níveis inadequados de alimentação, com acentuado consumo de produtos derivados de animais e baixo consumo de frutas, cereais e derivados. Isso muitas vezes é atribuído à prática da agricultura de subsistência, em que a produção é realizada para a sobrevivência do agricultor e seus familiares. (CARVALHO, E. O.; ROCHA, 2011 p.183; NUNES et al., 2014 p.4). Em contrapartida, na área urbana, o consumo alimentar é marcado pelo consumo excessivo de produtos processados, entre os quais ofast food predomina, conjugando o prazer e a regionalidade no hábito alimentar. (FRANÇA et al., 2012 p.5; SALAS MARTINS et al., 1994).

Aumentos na demanda de carne, baixos custos de alimentação, melhoria dos transportes, mudanças na tecnologia e organização da produção animal estão agora contribuindo para a criação de novos padrões de produção e consumo (FOUNDATION, 2014). O consumo alimentar, em termos de kcal/dia/pessoa, é a variável chave utilizada para medir e avaliar a evolução da situação mundial de alimentos. O mundo tem sofrido aumentos significativos no consumo de alimentos per capita. Nas três décadas de 1999-2001, houve um aumento de uma média de $2400 \mathrm{kcal} /$ pessoa/dia para quase $2.800 \mathrm{kcal} /$ pessoa/dia. (identificados na tabela 19 ).

Tabela 18: Consumo de alimento per capita (kcal/pessoa/dia)

\begin{tabular}{lccccccc}
\hline & $\mathbf{1 9 6 9 / 7 1}$ & $\mathbf{1 9 7 9 / 8 1}$ & $\mathbf{1 9 8 9 / 9 1}$ & $\mathbf{1 9 9 9 / 0 1}$ & $\mathbf{2 0 1 5}$ & $\mathbf{2 0 3 0}$ & $\mathbf{2 0 5 0}$ \\
\hline Mundo & 2411 & 2549 & 2704 & 2789 & 2950 & 3040 & 3130 \\
Países em desenvolvimento & 2111 & 2308 & 2520 & 2654 & 2860 & 2960 & 3070 \\
África Subsariana & 2100 & 2078 & 2106 & 2194 & 2420 & 2600 & 2830 \\
- Excluindo Nigéria & 2073 & 2084 & 2032 & 2072 & 2285 & 2490 & 2740 \\
Leste / Norte da África & 2382 & 2834 & 3011 & 2974 & 3080 & 3130 & 3190 \\
América Latina e Caribe & 2465 & 2698 & 2689 & 2836 & 2990 & 3120 & 3200 \\
Sul da Ásia & 2066 & 2084 & 2329 & 2392 & 2660 & 2790 & 2980 \\
Leste da Ásia & 2012 & 2317 & 2625 & 2872 & 3110 & 3190 & 3230 \\
Países industriais & 3046 & 3133 & 3292 & 3446 & 3480 & 3520 & 3540 \\
Países em transição & 3323 & 3389 & 3280 & 2900 & 3030 & 3150 & 3270 \\
\hline
\end{tabular}

Fonte: (ALEXANDRATOS et al., 2006 p.8) 
Este crescimento foi acompanhado por uma mudança estrutural significativa, na qual dietas se deslocaram mais para produtos animais, óleos vegetais, etc., e se moveram para longe de alimentos básicos, como raízes e tubérculos (Tabelas 19 e 20).

O aumento do consumo de alimentos na média mundial refletiu predominantemente o aumento da população dos países em desenvolvimento. Atualmente há oito países em desenvolvimento com uma população de 100 milhões ou mais. Desses, apenas Bangladesh permanece em níveis muito baixos de consumo de alimentos. China, Indonésia, Brasil e México fizeram a transição para níveis bastante elevados (na faixa 2900-3150 kcal). Em anos mais recentes (a partir de finais dos anos 1980) a Índia e o Paquistão também fizeram alguns progressos e agora estão se aproximando de níveis medianos de consumo de alimentos per capita após longos períodos de quase estagnação (Tabela 20). 
Tabela 19: Estimativa e projeção do consumo de alimentos - principais países

\begin{tabular}{|c|c|c|c|c|c|c|}
\hline kg/pessoa/ano & 1969/71 & $1979 / 81$ & $1989 / 91$ & 1999/01 & 2030 & 2050 \\
\hline \multicolumn{7}{|c|}{ Mundo } \\
\hline Cereais & 148,7 & 160,1 & 171 & 165,4 & 165 & 162 \\
\hline Cereais (todos os usos) & 302,8 & 325 & 329,3 & 308,7 & 331 & 339 \\
\hline Raízes e tubérculos & 83,7 & 73,4 & 64,5 & 69,4 & 75 & 75 \\
\hline Açucar (equiv. açuçar cru) & 22,4 & 23,4 & 23,3 & 23,6 & 26 & 27 \\
\hline Grãos & 7,6 & 6,5 & 6,2 & 5,9 & 6 & 6 \\
\hline Óleaginosas & 6,8 & 8,3 & 10,3 & 12 & 16 & 17 \\
\hline Carne & 26,1 & 29,5 & 33 & 37,4 & 47 & 52 \\
\hline Leite e produtos lácteos & 75,3 & 76,5 & 76,9 & 78,3 & 92 & 100 \\
\hline Outros Alimentos (kcal/pessoa/dia) & 216 & 224 & 241 & 289 & 325 & 340 \\
\hline Total alimentos (kcal/pessoa/dia) & 2411 & 2549 & 2704 & 2789 & 3040 & 3130 \\
\hline \multicolumn{7}{|c|}{ Países em desenvolvimento } \\
\hline Cereais & 146,3 & 161,7 & 173,7 & 165,7 & 166 & 163 \\
\hline Cereais (todos os usos) & 191,8 & 219,1 & 238,6 & 238 & 268 & 279 \\
\hline Raízes e tubérculos & 78,8 & 69,6 & 60,1 & 67 & 75 & 77 \\
\hline (Em desenvolvimento menos China) & 61,8 & 59 & 58,4 & 62,8 & 76 & 80 \\
\hline Açucar (equiv. açuçar cru) & 14,7 & 17,5 & 19,2 & 20,7 & 25 & 26 \\
\hline Grãos & 9,2 & 7,8 & 7,3 & 6,7 & 7 & 7 \\
\hline Óleaginosas & 4,9 & 6,5 & 8,6 & 10,4 & 14 & 16 \\
\hline Carne & 10,7 & 13,7 & 18,2 & 26,7 & 38 & 44 \\
\hline (Em desenvolvimento menos China e Brasil) & 10,7 & 12,5 & 13,6 & 15,9 & 26 & 32 \\
\hline Leite e produtos lácteos & 28,6 & 34 & 38,1 & 45,2 & 67 & 78 \\
\hline Outros Alimentos (kcal/pessoa/dia) & 123 & 140 & 171 & 242 & 285 & 300 \\
\hline Total alimentos (kcal/pessoa/dia) & 2111 & 2308 & 2520 & 2654 & 2960 & 3070 \\
\hline \multicolumn{7}{|c|}{ Países industriais } \\
\hline Cereais & 132,3 & 139,4 & 154,4 & 162,4 & 159 & 156 \\
\hline Cereais (todos os usos) & 531,1 & 542 & 543,7 & 591,8 & 641 & 665 \\
\hline Raízes e tubérculos & 74,2 & 67,1 & 69,4 & 66,7 & 61 & 57 \\
\hline Açucar (equiv. açuçar cru) & 40,5 & 36,7 & 32,6 & 33,1 & 32 & 32 \\
\hline Grãos & 3,4 & 2,8 & 3,2 & 3,6 & 4 & 4 \\
\hline Óleaginosas & 13,2 & 15,7 & 18,5 & 21,5 & 24 & 24 \\
\hline Carne & 69,7 & 78,5 & 84,3 & 90,2 & 99 & 103 \\
\hline Leite e produtos lácteos & 189,1 & 201 & 211,2 & 214 & 223 & 227 \\
\hline Outros Alimentos (kcal/pessoa/dia) & 486 & 500 & 521 & 525 & 565 & 580 \\
\hline Total alimentos (kcal/pessoa/dia) & 3046 & 3133 & 3292 & 3520 & 3520 & 3540 \\
\hline \multicolumn{7}{|c|}{ Países em transição } \\
\hline Cereais & 200,5 & 189,2 & 179,1 & 168,7 & 164 & 158 \\
\hline Cereais (todos os usos) & 653 & 777,6 & 767,8 & 499,1 & 618 & 688 \\
\hline Raízes e tubérculos & 140,2 & 118,4 & 97,1 & 103,3 & 99 & 94 \\
\hline Açucar (equiv. açuçar cru) & 41,9 & 45,9 & 43,4 & 36,5 & 39 & 41 \\
\hline Grãos & 4,1 & 3,1 & 2,3 & 1,6 & 2 & 2 \\
\hline Óleaginosas & 7,4 & 9,2 & 10,2 & 10,1 & 15 & 18 \\
\hline Carne & 49,5 & 62,9 & 70,7 & 44,4 & 59 & 68 \\
\hline Leite e produtos lácteos & 185,7 & 181,3 & 177,2 & 160,2 & 179 & 193 \\
\hline Outros Alimentos (kcal/pessoa/dia) & 331 & 372 & 333 & 317 & 365 & 390 \\
\hline Total alimentos (kcal/pessoa/dia) & 3323 & 3389 & 3280 & 2900 & 3150 & 3270 \\
\hline
\end{tabular}

Fonte: (ALEXANDRATOS et al., 2006 p.25) 
Tabela 20: Estimativa e projeção do consumo de alimentos - países em desenvolvimento

\begin{tabular}{|c|c|c|c|c|c|c|}
\hline $\mathrm{kg} /$ pessoa/ano & $1969 / 71$ & $1979 / 81$ & $1989 / 91$ & 1999/01 & 2030 & 2050 \\
\hline \multicolumn{7}{|c|}{ África Subsariana } \\
\hline Cereais & 115,3 & 114,3 & 118,8 & 123,3 & 142 & 155 \\
\hline Raízes e tubérculos & 193 & 175 & 184,3 & 191,2 & 211 & 205 \\
\hline (África Subsariana menos Nigéria e Gana) & 184,3 & 182,6 & 179,5 & 165,9 & 194 & 191 \\
\hline Açucar (equiv. açuçar cru) & 7,8 & 9,8 & 8,6 & 10 & 12 & 15 \\
\hline Grãos & 11 & 9,7 & 8,9 & 9,8 & 12 & 14 \\
\hline Óleaginosas & 8 & 8,4 & 8,5 & 8,9 & 12 & 13 \\
\hline Carne & 10,2 & 10,5 & 9,8 & 9,5 & 14 & 18 \\
\hline Leite e produtos lácteos & 29,6 & 33,7 & 29,8 & 28,3 & 34 & 38 \\
\hline Outros Alimentos (kcal/pessoa/dia) & 139 & 141 & 130 & 128 & 170 & 185 \\
\hline Total alimentos (kcal/pessoa/dia) & 2100 & 2078 & 2106 & 2194 & 2600 & 2830 \\
\hline \multicolumn{7}{|c|}{ Leste / Norte da África } \\
\hline Cereais & 179,3 & 199,7 & 211,8 & 203,5 & 199 & 193 \\
\hline Raízes e tubérculos & 16,6 & 26,5 & 31,8 & 33,7 & 33 & 33 \\
\hline Açucar (equiv. açuçar cru) & 20,4 & 28 & 28,2 & 27,7 & 29 & 30 \\
\hline Grãos & 6,2 & 6,3 & 8 & 6,6 & 7 & 7 \\
\hline Óleaginosas & 7,5 & 10,9 & 12,5 & 12,1 & 14 & 15 \\
\hline Carne & 12,6 & 17,3 & 19,6 & 21,7 & 35 & 43 \\
\hline Leite e produtos lácteos & 68,1 & 84,1 & 75 & 73,2 & 90 & 101 \\
\hline Outros Alimentos (kcal/pessoa/dia) & 224 & 277 & 298 & 333 & 370 & 385 \\
\hline Total alimentos (kcal/pessoa/dia) & 2382 & 2834 & 3011 & 2974 & 3130 & 3190 \\
\hline \multicolumn{7}{|c|}{ América Latina e Caribe } \\
\hline Cereais & 118,7 & 130,1 & 130,1 & 132,6 & 140 & 139 \\
\hline Raízes e tubérculos & 94,1 & 74,3 & 63,9 & 63,3 & 62 & 58 \\
\hline Açucar (equiv. açuçar cru) & 40,5 & 48,1 & 46 & 48,5 & 49 & 47 \\
\hline Grãos & 14,2 & 12,6 & 10,5 & 11,2 & 11 & 10 \\
\hline Óleaginosas & 6,8 & 10,1 & 12,1 & 11,8 & 15 & 16 \\
\hline Carne & 33,5 & 40,5 & 42,8 & 58,5 & 79 & 90 \\
\hline Leite e produtos lácteos & 84 & 96,9 & 94,5 & 108,8 & 136 & 150 \\
\hline Outros Alimentos (kcal/pessoa/dia) & 240 & 246 & 258 & 272 & 310 & 330 \\
\hline Total alimentos (kcal/pessoa/dia) & 2465 & 2698 & 2689 & 2836 & 3120 & 3200 \\
\hline \multicolumn{7}{|c|}{ Sul da Ásia } \\
\hline Cereais & 150,4 & 151,1 & 164,3 & 157,1 & 167 & 169 \\
\hline Raízes e tubérculos & 16,9 & 19,9 & 18,7 & 23,5 & 31 & 36 \\
\hline Açucar (equiv. açuçar cru) & 20,3 & 20,6 & 23,7 & 25,6 & 30 & 32 \\
\hline Grãos & 14,5 & 11,3 & 12,3 & 10,1 & 8 & 7 \\
\hline Óleaginosas & 4,6 & 5,8 & 7,2 & 9,7 & 15 & 18 \\
\hline Carne & 3,9 & 4,1 & 5 & 5,5 & 12 & 18 \\
\hline Leite e produtos lácteos & 37 & 41,6 & 55,1 & 67,6 & 106 & 129 \\
\hline Outros Alimentos (kcal/pessoa/dia) & 84 & 89 & 104 & 141 & 180 & 200 \\
\hline Total alimentos (kcal/pessoa/dia) & 2066 & 2084 & 2329 & 2392 & 2790 & 2980 \\
\hline \multicolumn{7}{|c|}{ Leste da Ásia } \\
\hline Cereais & 152,2 & 181,4 & 199,5 & 186,7 & 176 & 162 \\
\hline Raízes e tubérculos & 96,6 & 80,8 & 57,1 & 65,8 & 61 & 53 \\
\hline Açucar (equiv. açuçar cru) & 5,7 & 8 & 10,5 & 11,6 & 17 & 20 \\
\hline Grãos & 4,8 & 4,3 & 2,6 & 2 & 2 & 2 \\
\hline Óleaginosas & 3,5 & 4,7 & 7,8 & 10,6 & 15 & 17 \\
\hline Carne & 9,2 & 13,2 & 22,6 & 39,8 & 62 & 73 \\
\hline Leite e produtos lácteos & 3,7 & 5 & 7,4 & 11,3 & 21 & 24 \\
\hline Outros Alimentos (kcal/pessoa/dia) & 98 & 121 & 179 & 322 & 405 & 440 \\
\hline Total alimentos (kcal/pessoa/dia) & 2012 & 2317 & 2625 & 2872 & 3190 & 3230 \\
\hline
\end{tabular}

Fonte: (ALEXANDRATOS et al., 2006 p.26) 
No início do século XIX, o consumo anual mundial de carne era de cerca de $10 \mathrm{~kg}$ per capita, e a maior parte da carne era produzida principalmente por pequenos proprietários que utilizam recursos locais de terra, água e nutrientes (DELGADO et al., 1999; NAYLOR et al., 2005). De acordo com STEINFELD et al. (2006), em 1961 (o mais antigo recorde mundial), o consumo mundial de carne aumentou para cerca de $23 \mathrm{~kg}$ per capita. No início do século XXI, o consumo de carne per capita aumentou para $40 \mathrm{~kg}$ em média e $80 \mathrm{~kg}$ em países desenvolvidos. $\mathrm{O}$ comércio tem crescido mais rápido do que a produção. Globalmente, a participação do comércio como uma parte do consumo total de carne aumentou de 9,2\% em 1979-1981 para 12,8\% em 1999-2001. (FAO, 2013 p.122-123).

Urbanização e rendimentos crescentes são os principais motores de mudanças esperadas nos padrões de consumo. Nas últimas décadas, economias emergentes como a Ásia Ocidental, Norte da África, América Latina e Leste da Ásia têm sofrido mudanças rápidas e significativas nos padrões e níveis de consumo de alimentos. A disponibilidade per capita de alimentos nestas regiões está agora próxima de $3.000 \mathrm{kcal} /$ dia. Raízes, tubérculos e grãos têm sido gradualmente substituídos pelo aumento do consumo de trigo, arroz, açúcar, óleos vegetais, carne e produtos lácteos. Em contraste, o consumo per capita da África ainda está bem abaixo do limite de 2.500 $\mathrm{kcal} /$ dia. No outro extremo, a América Latina consome altas quantidades de carne per capita. (FAO, 2013 p.123).

A figura 30 mostra o atual consumo de carne ao redor do mundo, o qual é liderado pelo Hemisfério Norte, seguido de perto pelo restante do mundo. As projeções do aumento da população implicam em uma produção ainda maior de carne, o que implica em mais pressão para o desmatamento para a formação de pastos, maior consumo de água e alimentos para a alimentação dos animais, maior quantidade de emissão de gases do efeito estufa, entre outras questões. Isso indica que a industrialização e o comércio de carne influenciam tanto na apropriação de recursos chave para produção de carne como nos países chave consumidores de carne. (GERBENS-LEENES; NONHEBEL; IVENS, 2002). 


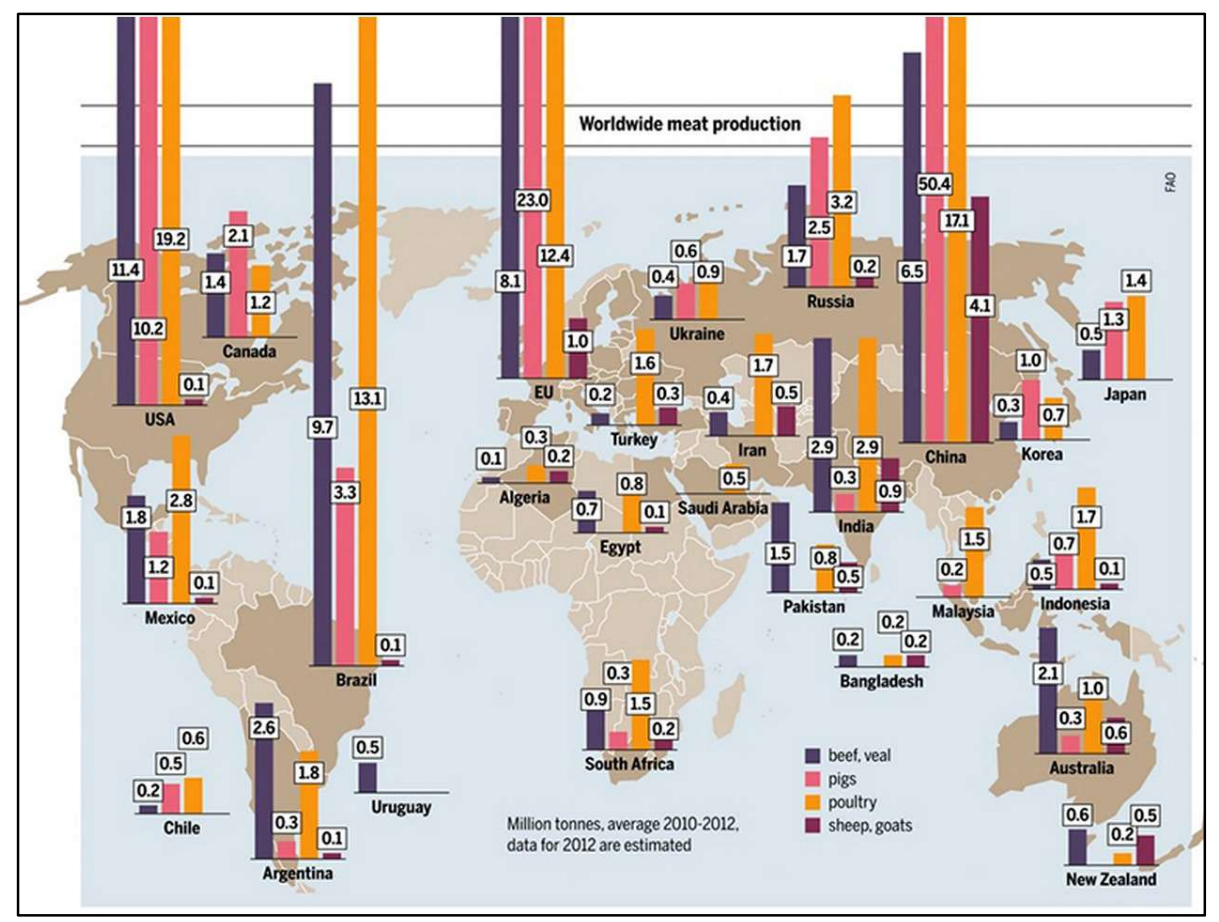

Figura 30: Produção de carne mundial

Fonte: Atlas da Carne (GERBENS-LEENES et al., 2002)

Estudos agrícolas sobre a segurança alimentar (GRIGG, 1994) estimaram que a mudança de uma dieta vegetariana para uma dieta rica em carne leva a um aumento de três vezes na terra necessária. Os resultados de um estudo comparativo sobre as necessidades de terra para cultivo (dieta carnívora versus dieta vegetariana) apresentaram uma diferença de três pontos (BOUMA; BATJES; GROOT, 1998; DE VRIES et al., 1995). Porém quando se considera uma dieta incluindo carnes, não só implica o consumo de mais tipos de carne, mas as mudanças ocorrem em todas as categorias de alimentos. As mudanças nos chamados itens vegetarianos no cardápio (óleos, bebidas, frutas, queijo, sorvete, bolos, etc.) também apresentam impactos sobre as necessidades de terra. 
Figura 31: Projeção do Consumo Mundial de Carne Bovina

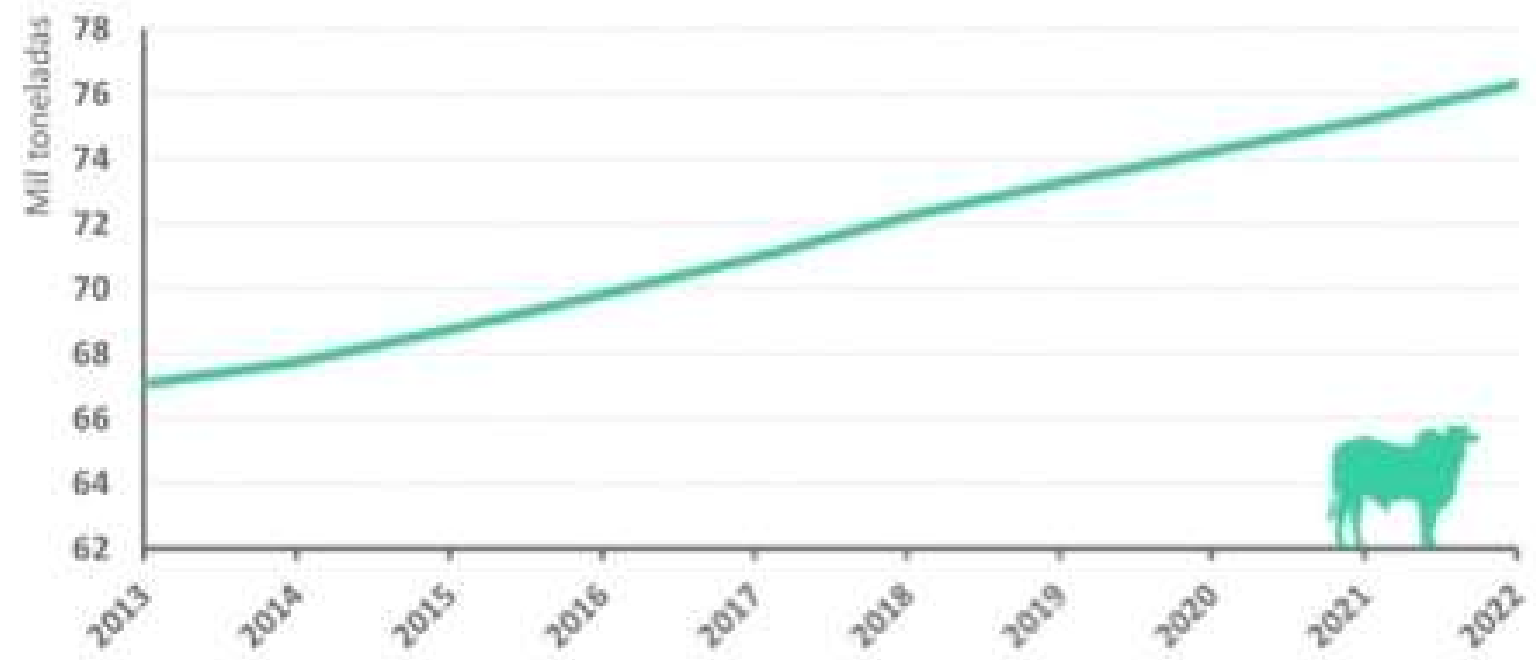

Fonte: (CSR/UFMG, 2015)

Figura 32: Projeção do Consumo Per Capita de Carne Bovina no Brasil

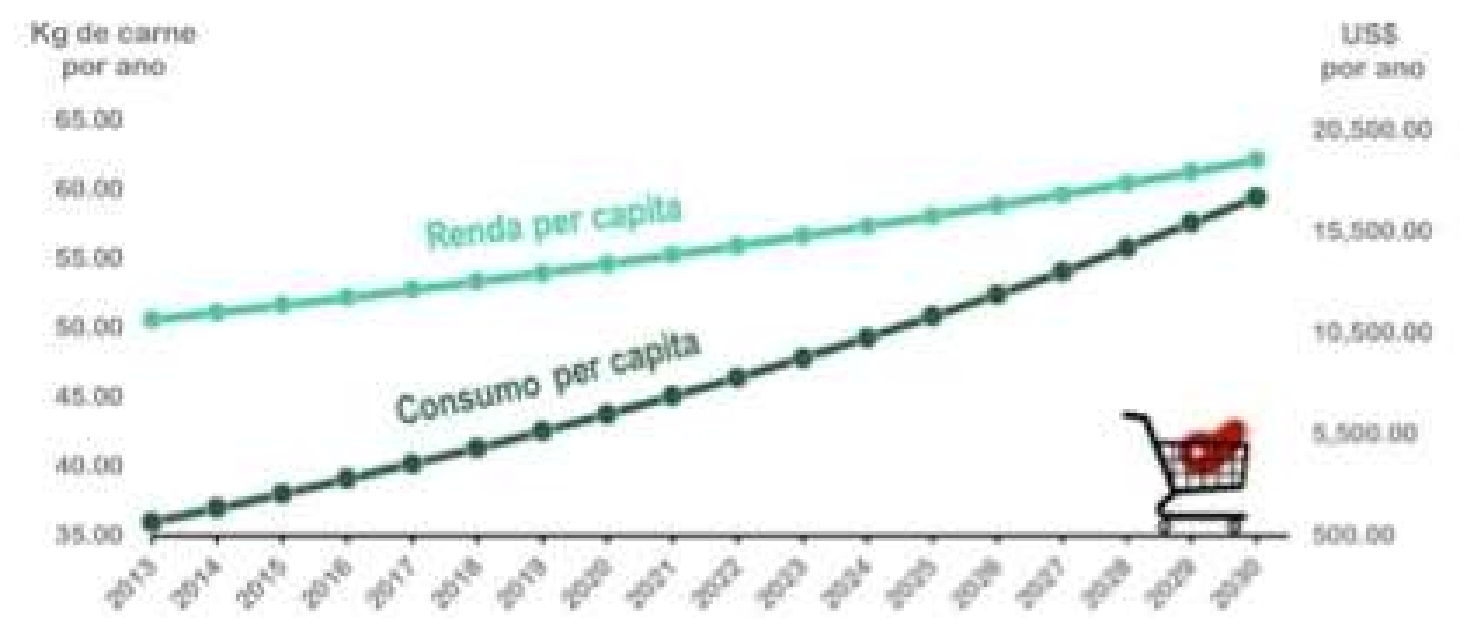

Fonte: (CSR/UFMG, 2015)

As figuras 31 e 32 evidenciam números que reforçam a necessidade de aumento da produtividade no setor produtivo de carne bovina, a fim de que se atinja uma maior produção com a mesma ou menor área de pastagem, haja vista que os mercados nacional e internacional estão à procura de produtos produzidos de acordo com os conceitos de bom manejo ambiental, bem-estar animal, certificação de origem e responsabilidade social.

Para atender ao crescente volume de cortes especiais de carne cobiçados pelo consumidor, há necessidade de conhecimento e atuação sistemática sobre os fatores que influenciam a qualidade das carcaças e, consequentemente, da carne, para que o Brasil se torne mais competitivo e passe a oferecer produtos mais homogêneos e que atendam às exigências dos frigoríficos e às necessidades do consumidor. 
Um dos quesitos levantados nesse aspecto é a redução de idade de abate, que incide na busca de eficiência do sistema (pasto e confinamento) e do atendimento das exigências de carcaças de qualidade com cobertura adequada de gordura, uma vez que a transformação dos alimentos consumidos em ganho de peso decresce com o aumento da idade do animal, o que pode resultar em gordura excessiva na carcaça. $\mathrm{O}$ abate dos animais com excesso de deposição de gordura não é interessante para o frigorífico, pois diminui o rendimento de cortes cárneos e aumenta a quantidade de aparas.

\subsubsection{O Consumo de Água}

Além da água utilizada para a produção de carne bovina, há também parte dela que é destinada diretamente ao consumo. O Water Footprint Network (comumente conhecido como Pegada Hídrica - PH) faz uma distinção entre a PH de produção e a de consumo. A identificada como consumo é a soma de uso direto e indireto de água dos recursos hídricos nacionais e internacionais através do consumo doméstico. VANHAM et al. (2013) avaliou em uma pesquisa diferentes tipos de dieta alimentar (referência "REF":1.996-2.005kcal; saudável "DGE": valores nutricionais baseados na Sociedade de Nutrição Alemã; vegetariana "VEG": mesmos valores da dieta saudável com substituição de carnes por outros produtos de mesmo valor nutricional; dieta combinada "COM": combina itens das dietas saudável e vegetariana). Os autores analisaram a variação no consumo de água nos Estados Unidos no período de 19962005 .

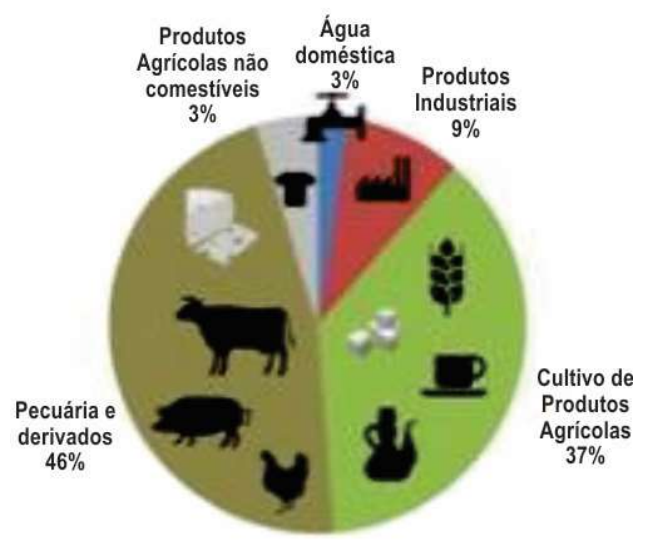

Fonte: (VANHAM et al., 2013 p.3) 
Para a produção de alimentos, a água sofre diferentes níveis de utilização devido a particularidades da produção em questão. Um exemplo disso é a produção agrícola, utilizada para alimentação humana e alimentação animal na produção pecuária. VANHAM et al. (2013 p.3) identificou que a PH de consumo doméstico representa apenas uma pequena fração da $\mathrm{PH}$ total. Mas dentre essa PH, 83\% dela é resultante da alimentação (detalhado na figura 33).

Os resultados da pesquisa indicaram que a dieta com menor consumo de água é a vegetariana, seguida por uma dieta combinada (indicado na figura 34). A redução no consumo de carne tem o maior impacto na redução da $\mathrm{PH}$.

Figura 34: PH de consumo nos Estados Unidos em diferentes dietas (1996-2005)

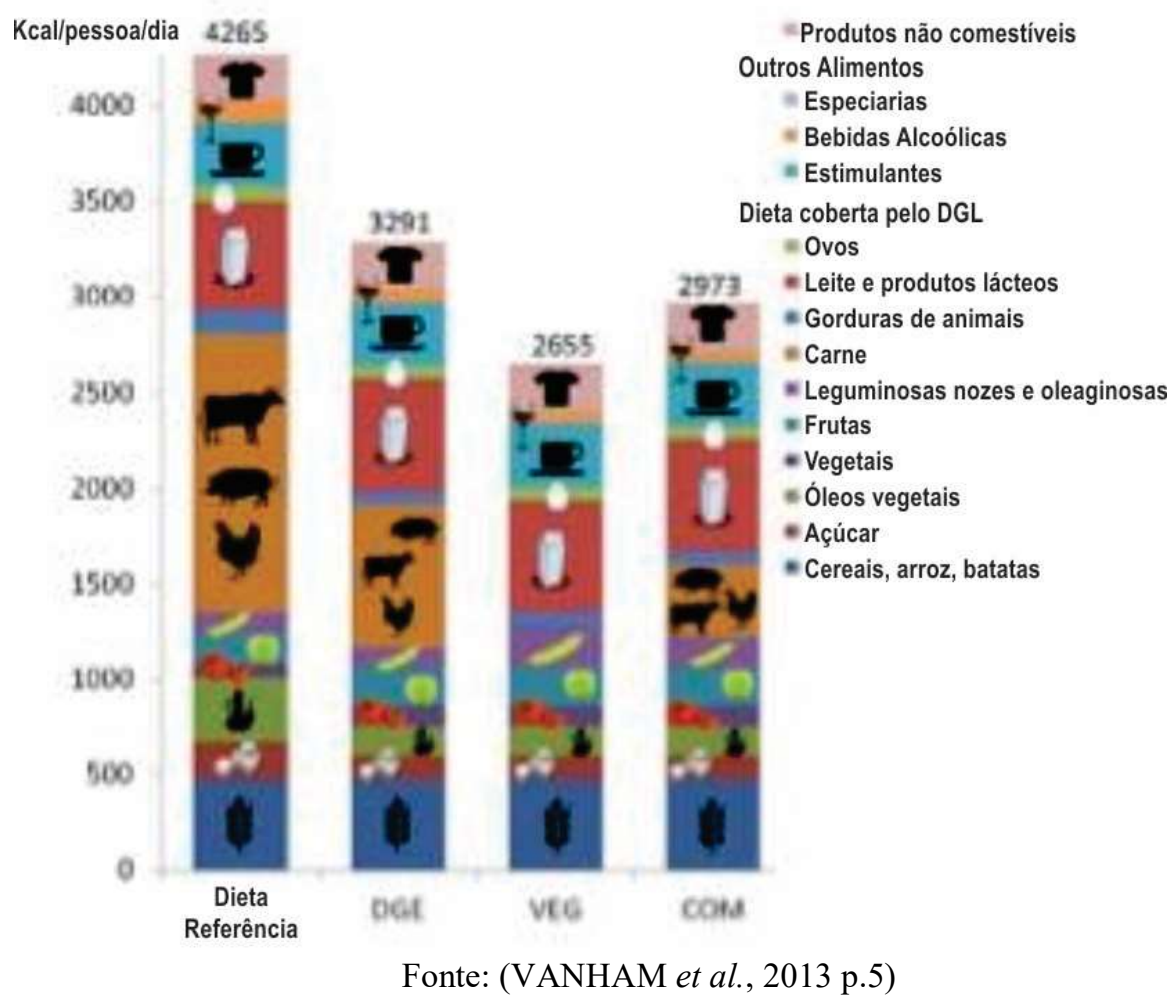

Além disso, foi identificado também que a dieta vegetariana é a que consome menor quantidade de água classificada como verde (água armazenada no solo ou temporariamente no topo do solo ou vegetação). (VANHAM et al., 2013 p.6).

Embora os resultados identificados sejam direcionados a uma pesquisa realizada com dados dos Estados Unidos, esse comportamento de consumo é notado também em outros países. Uma mudança de hábitos de consumo alimentar é prudente do ponto de vista ambiental e físico da população, porém é algo que pode ser desenvolvido em longo prazo através de medidas de conscientização e uso de variáveis que podem influenciar o consumo. 


\subsubsection{Variáveis influenciadoras no consumo de alimento}

Chegou-se à conclusão de que possivelmente há variáveis que influenciam nesse resultado, tais como variáveis sociais, politicas, econômicas, tecnológicas e culturais, citadas às vezes como "forças propulsoras", que possuem não somente a capacidade de influenciar, mas também de conduzir à mudanças globais. (FAO, 2013 p. 124).

De acordo com NEKOLA et al. (2013), algumas dessas forças podem ser:

1. Crescimento Populacional;

2. Crescimento Econômico;

3. Instituições Político-Econômicas;

4. Atitudes e convicções.

\subsubsection{Crescimento Populacional}

De Malthus até os dias de hoje, um tema central na redução do uso de recursos tem sido a exaustão dos recursos naturais induzida pelo crescimento, pela população humana e pela economia, e a ameaça que isso constitui para o bem-estar humano. Estudiosos esperavam entender os efeitos do crescimento populacional sobre o uso de recursos, sobre o bem estar econômico e social e, recentemente, sobre o meio ambiente. (NEKOLA et al., 2013) Poucos debates nas ciências sociais são tão acalorados quanto os que envolvem os impactos do crescimento populacional. As exigências impostas ao meio ambiente para a provisão de recursos e para a absorção de resíduos e poluentes sofrerão variação conforme $\mathrm{o} \mathrm{n}^{\mathrm{o}}$ de pessoas da população. Nessa hipótese, o crescimento populacional poderia ser considerado como a força primordial e não única, que precipita a degradação ambiental. (BRANDER, 2007 p.33; DIETZ, T.; ROSA; YORK, 2007 p.13).

Malthus levantou a hipótese de que uma população, cujo crescimento não fosse contido, dobraria seu número a cada 25 anos, ao passo que o produto do cultivo de uma mesma área de terra, no melhor dos casos, só poderia aumentar de uma quantidade fixa, que seria evidentemente uma proporção cada vez menor do produto total. Malthus estava se referindo à população e o colapso nas ilhas britânicas no século XIX. (NEKOLA et al., 2013 p.128). Apesar de Malthus considerar um crescimento da população de 3\% ao ano e ignorar o progresso tecnológico, é possível considerar que após 100 anos, ele seria 0,125 , ou seja, o resultado da 
contribuição da população adicional após um século de crescimento incontido levaria a produção alimentar como um assunto impossível de ser negligenciado. (DIETZ, T. et al., 2007; EHRLICH, P. R.; EHRLICH, 2013) Segundo a teoria de Malthus, a incompatibilidade do crescimento finito da agricultura e o continuo crescimento da população resulta em um declínio per capita e interrupção do crescimento - que seria o efeito da escassez econômica. (SINGER, 1988 p.90).

Cada pessoa extrai do meio ambiente algo visando suas necessidades básicas de vida alimento, água, vestuário, moradia e assim por diante. Ao passo que o padrão de vida é alterado, o consumo do meio ambiente também se altera e passa a gerar um impacto proporcional sobre o meio ambiente global. (STERN, P. C. et al., 1993 p.XXII e XXIII). O tamanho máximo ou ideal de uma população pode ser determinado pela capacidade física do planeta de suportar pessoas. Essa capacidade é determinada pela área de terra/espaço físico, disponibilidade de recursos minerais e água, potencial produção de comida e habilidade/capacidade de sistemas biológicos absorverem civilizações sem avarias que privam a humanidade de serviços essenciais. (JORGENSON; BURNS, 2007; MORSE; VOGIATZAKIS, 2014; ÖZLER; OBACH, 2009; WANG; WANG; SHAO, 2014).

Há quem pense que o crescimento da população resulta indiscutivelmente em crescimento econômico. Calculando que o crescimento econômico global continuará mantendo-se numa taxa elevada no futuro (de acordo com projeções das Nações Unidas e Banco Mundial para cerca de 10 bilhões em 50 anos) a produção econômica global se quadruplicaria entre 1990 e 2040. A produção e o consumo de bens são regidos por uma lei natural fundamental - a conservação da matéria. Dessa forma, qualquer coisa que entre na produção e consumo deve sair, seja como bens e serviços úteis ou como resíduos de materiais. Uma vez que a conversão de insumos em produtos úteis nunca é completa, é justo dizer que a atividade econômica inevitavelmente pressiona o meio ambiente ao gerar resíduos (os quais geram custos sociais). (EHRLICH, P.R. et al., 1973 p.226).

O tamanho, a estrutura e o crescimento da população tem um efeito duplo sobre o funcionamento da economia: eles são os principais determinantes da oferta de força de trabalho, e ao mesmo tempo, influenciam no consumo. Se os homens trabalhassem apenas com suas mãos e se os recursos naturais fossem livres e ilimitados, as consequências econômicas da dinâmica populacional se compensariam mutuamente. Cada acréscimo na população 
aumentaria a oferta e a procura mais ou menos na mesma proporção. (QUIRINO et al., 1999 p.39). A acumulação de capital e o consumo competem pelos mesmos recursos e dessa forma, cada aumento da população eleva o consumo e ao mesmo tempo a necessidade de acumular capital para proporcionar aos trabalhadores adicionais emprego produtivo. Por meio dessa análise é possível verificar que o crescimento populacional nem sempre é benéfico para o desenvolvimento econômico, mas que a avaliação do seu papel deve ser feita à luz das condições específicas em que cada país de encontra. (STERN, P. C. et al., 1993 p.69 e 70).

A teoria de Malthus recebe críticas de alguns economistas que afirmam que ele estava errado em suas afirmações. BRANDER (2007 p.2) analisa as afirmativas de Malthus como um “julgamento prematuro" baseado em um curto período histórico e não como uma previsão segura. Além isso, Malthus considerava que a melhoria nas condições humanas derivadas de avanços tecnológicos era possível, mas não provável. (BRANDER, 2007 p.5).

Há quem avalie que a solução dos problemas virá apenas pela estabilização da população, pois o contínuo crescimento de capital de uma sociedade não é sustentável assim como o contínuo crescimento da população. Estudos indicam que a solução para o consumo de recursos naturais não é a redução da quantidade de seres que os consomem e sim uma mudança e mentalidade e comportamento, que é um tanto mais além do que o controle de natalidade. (MEADOWS, D. et al., 2004 p.237 e 240).

\subsubsection{Crescimento Econômico}

A atividade econômica tem sido extensiva, gerando crescimento e ao mesmo tempo de forma involuntária, mudanças ambientais em nível global. O crescimento econômico pressiona o meio ambiente e o nível de pressão é determinado pelo padrão de bens e serviços produzidos, número da população e da quantidade ou base de recursos utilizados para o desenvolvimento econômico. (EHRLICH, P. R.; EHRLICH, 2013).

Muitos estudiosos têm procurado investigar aspectos da população e o consumo de alimentos, que é o tema central dessa pesquisa e alguns têm encontrado correlação entre variáveis como alimentação e renda per capita de cidades e países. (SCHLINDWEIN; KASSOUF, 2006;2007; VANHAM et al., 2013). Há quem responsabilize a pobreza sobre pelos efeitos ambientais. (BRANDER, 2007 p.9; SINGER, 1988 p.230 e 235). 
Contudo, ao longo das últimas décadas vêm ocorrendo muitas mudanças socioeconômicas e demográficas em todas as regiões do mundo. Entre essas mudanças pode-se destacar composição das famílias, participação da mulher no mercado de trabalho e na urbanização, entre outros. (SICHIERI; CASTRO; MOURA, 2003). Essas mudanças se dão em paralelo e influenciam na geração de uma nova tendência de gastos familiares com alimentação. (SCHLINDWEIN; KASSOUF, 2006 p.550).

Segundo PROCHASKA; SCHRIMPER (1973 p.595), a afluência econômica é um importante fator que influencia na demanda por variedade de alimentos e isso é comprovado ao longo dos tempos. Um exemplo disso é o gasto per capita para alimentação "fora de casa" que modificou de US\$ 83 (1951) para US\$ 141 (1971). Enquanto nos últimos anos as taxas de atividade masculina na economia mantiveram-se em patamares semelhantes $(75 \%)$, as das mulheres se ampliaram significativamente, passando de 30\% para 45\%. (REDMAN, 1980). Quando se compara a participação da mulher no mercado de trabalho e a taxa de urbanização, verifica-se uma forte inter-relação entre essas duas variáveis. Considerando-se praticamente o mesmo período, (últimos 25 anos), tem-se um acréscimo de quase 14 pontos percentuais na taxa de urbanização. Essas mudanças refletem, de certa forma, uma nova tendência de gastos com alimentação como, por exemplo, o aumento no consumo de alimentos prontos e da alimentação fora de casa, bem como uma mudança do consumo de alimentos tradicionais "tempointensivos" para o consumo de alimentos de fácil e rápido preparo. (SCHLINDWEIN; KASSOUF, 2007 p.423-424).

Pesquisas realizadas em países africanos indicaram que quando os índices de renda per capita são baixos, o alimento de origem animal apresenta queda de demanda, enquanto que o consumo de grãos, frutas e hortaliças sofre aumento contínuo. (BRASHARES et al., 2011). Isso nos leva a interpretar que alterações em renda per capita provocam alterações no consumo de alimentos. (VANHAM et al., 2013).

\subsubsection{Instituições Político-Econômicas e o Marketing}

O meio ambiente global reage às ações dos mercados, dos governos e da economia política internacional. Os mercados são normalmente imperfeitos, e o impacto da atividade econômica sobre o meio ambiente depende de qual método de administração ambiental em mercado 
imperfeito está sendo aplicado. A estrutura e as políticas governamentais também podem ter significativas consequências ambientais, intencionais ou não. E a economia política internacional, com sua divisão global da mão de obra e riqueza pode promover abusos ambientais. Os efeitos dependem da política em nível nacional e do comportamento de agentes econômicos particulares. (HOCKLEY; JONES; GIBBONS, 2008).

A globalização e o desenvolvimento das tecnologias de informação têm facilitado o crescimento da confiança entre as pessoas ao redor do mundo. Os governos incentivam ao consumo e inflação enfrenta oscilações a fim de alimentar o desenvolvimento econômico. (BROWN, J. H. et al., 2014 p.24-25) Assumindo que melhores padrões implicam maior consumo, é natural esperar uma maior demanda de recursos em um futuro próximo. Assim, o padrão de distribuição de recursos, como energia, alimentos e água, e, como uma categoria separada, o PIB, teria de ser reajustado acompanhando a evolução da economia. Esse crescimento exige novas demandas significativas sobre os recursos e com a alimentação não é diferente: o consumo de alimentos tem relação com o crescimento econômico de uma nação ou população. (BRASHARES et al., 2011; TEGTMEIER; DUFFY, 2004).

Na década de 80, a literatura de marketing passa a concentrar esforços em uma discussão voltada para as necessidades, preferências e desejos do cliente, e posteriormente para customer value, como foco de estratégias para a geração de vantagem competitiva. Apesar dos avanços nessas discussões, o valor para o cliente ainda é encarado como um constructo complexo. Uma proposta para o entendimento desse construto é expressa na definição de WOODRUFF; GARDIAL (1996 p.142) que estabelece o valor para o cliente como "a preferência e avaliação, percebida pelo cliente, dos atributos do produto, desempenho dos atributos, e consequências geradas pelo uso, que facilitam ou bloqueiam o alcance dos objetivos e propósitos dos clientes nestas situações". No entanto, compreender como os consumidores traduzem características e consequências de uso em valores permanece um desafio.

Seguindo essa nova lógica do consumo, faz-se necessário entender os fenômenos que provocaram profundas alterações sociais e culturais e, consequentemente, no comportamento dos consumidores. O consumo moderno é resultado de vários séculos de mudanças sociais, econômicas e culturais. Cultura (integração lógica e social de representações coletivas) e consumo assumiram uma relação sem precedentes no mundo moderno. (BOURDIEU; MICELI, 1974). Sob este mesmo aspecto, o consumo adquire uma dimensão simbólica e passa 
a exercer uma função social, tanto de inclusão e dissociação. Os atos de consumo exprimem também uma posição social, por serem característicos de um grupo de determinado status. (BOURDIEU; MICELI, 1974). Ao mesmo tempo em que o valor funcional dos produtos diminuiu em sua importância, aumentou o seu espaço de valor enquanto troca simbólica (uma rede de significados conectados com áreas da vida social). (TILMAN; CLARK, 2014; WEBER; BENTZ; HOHLFELDT, 2002).

Atualmente novas tecnologias da mídia influenciam os padrões de vida cotidiana, reestruturaram as relações sociais e de trabalho e aceleraram a disseminação e o poder da cultura veiculada através da mídia. O desenvolvimento e a expansão geográfica da mídia desempenharam papel fundamental na reestruturação da identidade contemporânea e na conformação de pensamentos e de comportamentos. As imagens da cultura da mídia são importantes tanto pela maneira como são construídas como pelos significados e valores que transmitem e que são incorporados. Um dos veículos utilizados pela mídia e que tem o poder de impulsionar o consumo e de atuar como mecanismo importante de socialização é a propaganda. Ela apresenta muitas vezes uma imagem utópica da realidade, associando o consumo de determinados produtos a metamorfoses pessoais. Os indivíduos identificam-se com valores, modelos e comportamentos sociais transmitidos através dela. (KELLNER; BENEDETTI, 2001 p.221-222). Em suma, tanto as instituições político-econômicas como o marketing e a mídia atuam como agentes poderosos na construção da identidade de consumo. (HOCKLEY et al., 2008).

\subsubsection{Atitudes e Convicções}

Convicções, atitudes e valores relacionados às posses materiais e a relação entre a humanidade e natureza frequentemente são vistas como algo que pode ter significativa influência sobre o comportamento no uso dos recursos - mesmo quando as variáveis sócio-estruturais e econômicas se mantêm constantes. (JORGENSON; BURNS, 2007).

A partir da revolução científica do século XVI (Galileu Galilei, Descartes, Francis Bacon e outros) aprofundada com a primeira revolução industrial, foi gerado pelo Ocidente, (a partir de 1730 na Inglaterra), o grande ideal da Modernidade: o progresso ilimitado. Segundo (HUYSMAN et al., 2015; MONTOYA; YOUNG, 2013; PARENTE; PARENTE, 2013), esse progresso foi desenvolvido mediante um processo industrial, que exigia a produção de bens de 
consumo em grande escala, baseado em uma exploração sistemática da Terra, tido como um baú de recursos, sem espírito e entregue ao bel-prazer humano, e que teve como consequência a geração de grande riqueza nos países centrais e colonizadores e imensa desigualdade, pobreza e miséria nas periferias desses países e principalmente nos países colonizados. Este símbolo ideal de Modernidade, e a sociedade gerada foram globalizados e praticamente todas as sociedades do mundo atual se veem obrigadas a alinhar-se a eles, o que equivale a ocidentalizarse. Para LORENZ (1974) o padrão desse ideal da Modernidade é consumir de forma indiscriminada, e para isso exige-se que a produção seja conduzida de forma crescente, desconsiderando as externalidades, as quais envolvem a degradação da natureza e geração de desigualdades sociais que não são necessariamente computadas como custos.

Hoje, já distantes daqueles primórdios, é possível se aperceber de que esse processo industrial trouxe, indubitavelmente, grandes benefícios à humanidade, como a melhoria nas condições da vida e de saúde, reinventou as possibilidades e formas de comunicação de humanos com suas próprias culturas, encurtou distâncias, prolongou a vida, enfim, trouxe um sem-número de comodidades que vão da geladeira ao automóvel e ao avião, da luz elétrica à televisão e à internet. Em contrapartida, esse ideal de Modernidade esgotou suas potencialidades e passou a ser altamente dilacerador dos laços sociais e destrutivo das bases que sustentam a vida. Sua última consequência é a percepção nos seres humanos de que os limites da Terra juntamente com seus recursos não renováveis são infinitos, a qual é traduzida em duas pressuposições ilusórias: a primeira de que os recursos naturais seriam infinitos; a segunda, de que é possível rumar infinitamente na direção do futuro, pois o progresso não padece limites. Ambas as pressuposições podem ser consideradas falácias que moveram mentes e corações por muitas gerações e conduziram a humanidade à atual crise ambiental, que resulta na conclusão de que um planeta finito não suporta um projeto infinito, ou seja, um balanço não equacionado.(PARENTE; PARENTE, 2013).

Mesmo com iniciativas capitalistas, a humanidade tem desenvolvido uma gradativa consciência sustentável e isso é notado na população e nas organizações. (PARENTE; PARENTE, 2013). Porém há o surgimento de um assunto recente na literatura, chamado de Dissonância Cognitiva, que pode ser definida como uma distância entre o que se acha correto (moral) e o que se pratica (ética). Para o ser humano, ela pode ser percebida como um conflito pessoal, exceto se um padrão de crenças, conceitos e valores sólidos seja estabelecido e mesmo que novos estímulos sejam recebidos, não causará influência para mudanças de proceder. (MULAJ; JACK, 2012). 
O equilíbrio entre o meio ambiente e a relação de consumo é dependente da harmonia entre o apetite humano de poder e consumo com o frágil meio ambiente, além do que é importante observar, em última análise, a necessidade de restaurar a harmonia entre os próprios seres humanos. (COSTA; IGNÁCIO, 2011 p.4).

A seguir, o capítulo 5 fará a junção do uso de recursos naturais na pecuária bovina de corte (abordado no capítulo 2) ao impactos ambientais identificados nos capítulos 3 e 4 com respeito a produção e ao consumo de carne bovina, por meio do conceito de sustentabilidade.

\subsection{Sustentabilidade na Produção e Consumo Bovino de Corte}

A sustentabilidade tem atraído olhares e um amplo apoio como uma atitude de conservação ambiental ideal, e com isso se tornou para muitos, a luz orientadora de ações que visam à preservação do meio ambiente. A sustentabilidade tem sido utilizada como meio e como objetivo de se atingir uma meta, seja ela ambiental, baseada em diversidade ecológica (FERNANDEZ et al., 2012; SCOONES, 2007; YORK, 2009), econômica, baseada em desempenho financeiro e social, visando as pessoas e a sociedade. (BROWN, J. H. et al., 2014; DRECHSLER et al., 2007; EDWARDS; ABIVARDI, 1998; M. BAGLIANI; PROCOPIO, 2003; NEWTON; FREYFOGLE, 2005 p.25; PULSELLI et al., 2008).

\subsubsection{Sustentabilidade: conceito e estudos}

O conceito de sustentabilidade tornou-se popular a partir de 1987 no relatório Brundtland e definido como o "desenvolvimento que satisfaz as necessidades do presente sem comprometer a capacidade das gerações futuras satisfazerem as suas próprias necessidades". (BRUNDTLAN, 1987; FERNANDEZ et al., 2012 p.77; SCOONES, 2007 p.590).

No entanto, para muitos o termo "sustentabilidade" permanece ainda vago sobre quais vertentes ela se sustenta exatamente. (GALE; CORDRAY, 1994; LACKEY, 1998 p.21-30; LÉLÉ; NORGAARD, 1996; NOSS, 1991; REDCLIFT, 2005 p.142-155; SITARZ, 1993; WILLERS, 1994). Em algumas pesquisas, a sustentabilidade é comparada ao termo eficiência, tido como um atributo utilizado para se alcançar um objetivo, que pode ser mais abrangente do que somente algo “em longo prazo". (NEWTON; FREYFOGLE, 2005 p.24). 
Como meta popular, a sustentabilidade ainda tem um efeito de pouco fascínio para muitos, pois incorpora a ideia de uma vida estagnada ou repetitiva, que implica em um comportamento restritivo. (CALDER; CLUGSTON, 2003; KATES, 2011).

Autores defendem a ideia de que a sustentabilidade deveria tornar mais claro seu objetivo, que nada mais é do que a preservação do ambiente através de ações e mudanças de comportamento da sociedade. (NEWTON; FREYFOGLE, 2005) Essa pesquisa segue esses preceitos: apoiada em fatos que projetam más consequências, ações de mudança e cenários que identificam o resultado dessas mudanças.

\subsubsection{Sustentabilidade e a produção de carne bovina}

Quando sustentabilidade está associada a um sistema humano como a agricultura ou ao desenvolvimento, os seres humanos são os atores principais envolvidos e capazes de produzir mudanças. Contudo, o assunto é menos evidente quando a sustentabilidade é associada a um objeto, como o futuro ou o planeta. A humanidade será atingida pelo futuro, independente do que seja feito, pois possui um controle modesto sobre isso. Porém, a diferença é a forma como será afetada pelo futuro - que está em construção no atual presente. (LACKEY, 1998 p.11; NEWTON; FREYFOGLE, 2005 p.25).

A Avaliação Ecossistêmica do Milênio, estruturada pela Organização das Nações Unidas entre os anos 2001 a 2005, envolvendo cerca de 1.300 cientistas de 95 países além de 850 outras personalidades da ciência e da política identificou que dos 24 serviços ambientais essenciais para a vida (água e ar limpos, regulação dos climas, alimentos, energia, fibras e etc.), 15 deles se encontravam em processo de degradação acelerada. DIETZ, T. et al. (2007) E os impactos ambientais resultantes da agricultura são maiores do que a produção de bens manufaturados. Mediante esse cenário apresentado, estudiosos analisam as melhores formas de se alterarem hábitos alimentares em prol do futuro do planeta. No entanto, as expectativas desses rumam para cenários pessimistas em sentido ambiental, no qual os impactos da agricultura devem aumentar substancialmente devido ao crescimento populacional e ao aumento do consumo de produtos de origem animal. Além disso são percebidos impactos ambientais, que aumentam para cerca de $80 \%$ quando se dobra a renda per capita.(BOFF, 2012 p.24). 
Segundo STEFFEN et al. (2011); ZALASIEWICZ et al. (2008), atualmente foi alcançado um nível de agressão ambiental que equivale a uma espécie de guerra total em que a humanidade arranca da terra algo em benefício próprio, sem qualquer sentido de retribuição e sem qualquer disposição de dar-lhe repouso e tempo para se regenerar. Consequentemente, é rompido um limite que uma vez ultrapassado põe em risco a saúde de seus habitantes. (GUTZLER et al., 2015).

A produção de alimentos passou por uma grande transição durante as últimas décadas. A transformação da agricultura em todo o mundo a partir de utilização de métodos tradicionais, de baixa tecnologia para a sua atual utilização intensiva de energia, fertilizantes, máquinas e irrigação tem levado a aumentos significativos na produção agrícola. Essa transformação é resultado de fatores tais como programas de pesquisa agrícola, inovação tecnológica, o desenvolvimento de novas infraestruturas e à expansão do volume e capacidade logística da economia mundial. (FERNANDEZ et al., 2012; VINNARI; TAPIO, 2009 p.269).

A Revolução Verde, poderosa influência nessa transformação, ocorrida nas décadas de 60 e 70 , consistiu na produção combinada de variedades melhoradas de cereais, arroz e trigo, por meio da utilização de fertilizantes e irrigação cuidadosamente controlada com o objetivo de gerar aumento da produção agrícola em países menos desenvolvidos. A Revolução Verde influenciou o curso do desenvolvimento social e econômico no Terceiro Mundo e essas não foram as únicas consequências. (CLEAVER, 1972 p.177-180; SMULDERS; TOMAN; WITHAGEN, 2014).

A sustentabilidade dos sistemas de produção bovina de corte tem sido constantemente debatida nas últimas décadas, especialmente com foco na influência dos bovinos sobre o ambiente e a conservação de recursos genéticos animais. Segundo SANTOS et al. (2003), um manejo sustentável não envolve a degradação ambiental, mas utiliza técnicas apropriadas, economicamente viáveis e socialmente aceitáveis e por isso pode ser chamado de Agroecossistema Sustentável, pois mantém a produtividade ao longo do tempo, com a introdução mínima de insumos externos (suplementos alimentares, uso de fertilizantes, antibióticos, etc.) e sem degradar os recursos naturais.

Há diferentes estudos de agroecologia que administram uma visão holística de agroecossistemas sustentáveis e como esses podem contribuir para tornar o sistema produtivo econômico e ao mesmo tempo sustentável (GLIESSMAN, 1990). Porém grande parte deles culmina no fato de que a produção animal em sistemas extensivos é uma função exercida pela 
relação solo-planta-animal e outros componentes do meio ambiente, em que a complexidade dessa relação pode ser sanada através da compreensão de como o pastejo afeta o solo. (BROWN, J.; ASH, 1996). Essa relação tem determinado grau de complexidade e em parte devido a isso, grande parte das pesquisas tem se concentrado em investigar o sentido prático dos resultados, com vistas ao incremento da produção das pastagens e aumento da produção animal ao invés de obter a devida compreensão do funcionamento dos processos e consequências. (CARVALHO, P. D. F., 1997).

Há uma demanda mundial por produtos naturais e o Brasil, sendo um país reconhecido por possuir uma riqueza em recursos naturais, é encarado como uma das perspectivas no assunto. Entretanto, carece de pesquisas que contribuam não somente em discussões de uma economia produtiva, mas também com cenários de preservação ambiental, os quais não colidam com necessidades sociais. (SANTOS et al., 2003).

Atualmente surgem no mercado diferentes denominações de pecuária bovina de corte mantidas exclusivamente em pastos: boi verde, boi de capim, boi ecológico, boi natural, boi biológico, entre outros. Muitos criadores brasileiros buscam beneficiar-se do sistema natural ou orgânico de pecuária de corte, com o objetivo de identificar alternativas tecnológicas que aumentem a produtividade animal de forma sustentável. A diferenciação entre o sistema orgânico e os demais são os procedimentos descritos na Instrução Normativa $n^{\circ} 007$ (SISLEGIS, 1999) e a legislação ambiental $n^{\circ}$ 4771, de 15 de setembro de 1965. (CÂMARA DOS DEPUTADOS, 2012).

Embora a palavra sustentabilidade seja amplamente usada, a implementação do seu uso parece difícil e para que isso possa ocorrer é necessário estabelecer ferramentas para medir e monitorar a sustentabilidade, ou seja, caracterizar uma situação atual, alertar para situações de risco e prever situações futuras. (DE WIT et al., 1995).

\subsubsection{Sustentabilidade e consumo de carne bovina}

A transformação agrícola, que foi impulsionada pela revolução verde, tornou a maioria dos alimentos disponíveis a preços mais baixos a quase todos os consumidores no mundo ocidental nos anos sessenta e setenta. Desde então, os consumidores tiveram uma liberdade de escolha 
em relação à alimentação, acompanhando a diversidade de produtos disponível no mercado alimentício. (VINNARI; TAPIO, 2009 p.269).

A eficiência logística, a variedade de produtos e a aparente facilidade de compra de produtos alimentares em muitos países não significa que as escolhas de consumo de alimentos não são problemáticas. Sociedades ocidentais passaram de uma situação em que a abordagem "produzir o suficiente" resultou em problemas de superprodução. Além disso, a revolução verde também teve grandes impactos sociais e ecológicos. Um dos efeitos da revolução verde tem sido o crescimento do consumo de carne nos países desenvolvidos nas últimas décadas. (CLEAVER, 1972; HEIKKINEN; MAULA, 1996; VINNARI; TAPIO, 2009 p.269-270).

Pesquisas indicam que o meio ambiente está sendo degradado ou tem se tornado improdutivo em algumas regiões por causa do impacto ambiental do consumo de carne, plantio de alimentos (SCHLESINGER; BERNHARDT, 2013; TILMAN et al., 2001), uso de energia (PIMENTEL, D.; MARCIA H. PIMENTEL, 2007) e água (CHAPAGAIN, ASHOK KUMAR, 2006; CHAPAGAIN, ASHOK K; HOEKSTRA, 2004; CHAPAGAIN, A. K.; ORR, 2009; PIMENTEL, DAVID et al., 1997).

Globalmente, a agricultura é responsável por cerca de $20 \%$ do total de emissões de gases do efeito estufa, e desse montante, aproximadamente, $35 \%$ vêm da produção pecuária (STERN, N., 2007 p.IV), (conforme já mencionado no capítulo 2 dessa pesquisa), resultados da produção de carne bovina, que gera quantidades altas de metano, que contribui de forma significativa para as emissões de gases de efeito estufa (SUBAK, 1995). De acordo com OGINO et al. (2007), um quilo de carne é equivalente à quantidade de $\mathrm{CO}_{2}$ emitida pelo carro médio europeu a cada $250 \mathrm{~km}$. Além disso, ao se avaliar as diferenças entre os padrões alimentares onívoros, vegetarianos e veganos, as emissões de gases de efeito estufa resultantes do consumo de carne foram evidentes (BARONI et al., 2006).

Em virtude disso, são apresentadas propostas, a partir de uma perspectiva ambiental, a favor da diminuição dos níveis de consumo de carne, e algumas medidas para alcançar esse objetivo foram sugeridas. GOODLAND (1997) propôs que os alimentos mais elevados na cadeia alimentar (como carne e leite) sofram alta tributação em comparação com outros alimentos (como legumes e frutas). MCMICHAEL et al. (2007) desenvolveram uma estratégia de redução 
e a convergência como uma forma de limitar o consumo global de carne. Apesar de promissor, tal estratégia possui algumas dificuldades de implementação.

Para planejar e implementar procedimentos que influenciem alterações no consumo de alimentos, é necessário um entendimento amplo de fatores que influenciam esse consumo. (COSTA; IGNÁCIO, 2011) Além disso, as perspectivas de consumo desses fatores devem ser analisadas a fim de compreender o nível de influência necessária para que as alterações sejam provocadas de forma certeira. (VINNARI; TAPIO, 2009 p.271-272). Porém ao se analisar o consumo com certa medida de controle, um dos impactos que pode surgir é o impacto econômico. Ao se calcular o peso da sustentabilidade, economistas defendem que o consumo é benéfico para o desenvolvimento de uma sociedade e especialmente de futuras gerações (ponto também defendido pela visão sustentável). (KOWALSKI; SWILLING, 2011 p.1-5).

Nota-se que mundialmente há uma tendência crescente dos consumidores na procura de alimentos naturais, com receio de que aditivos alimentares (implantes hormonais) e uso frequente de antibióticos venham prejudicar a saúde (GLOBO G1, 2016; REBELLO; REBELLO, 2013). Portanto, há um crescente aumento no interesse dos consumidores pela carne de bovinos criados a pasto ("natural beef" ou "grass fed"), o que tem permitido a alguns produtores desenvolver um nicho de mercado apropriado (GRANNIS; HOOKER; THILMANY, 2000; SMITH et al., 1997). Valor agregado, tais como orgânico, natural e alimentado exclusivamente a pasto são potencialmente atrativos aos consumidores. O número de consumidores dispostos a pagar mais por esses tipos de produtos está se expandindo rapidamente. (GOSS; HOLCOMB; WARD, 2002; ZIEHL; THILMANY; UMBERGER, 2005). 


\section{ANÁLISE E DISCUSSÃo DE RESULTADOS}

Esse capítulo destina-se a apresentação dos resultados investigados nessa pesquisa.

\subsection{Consumo e Produção de Carne Bovina}

Conforme já delineado, na segunda fase da pesquisa foram identificados por meio da aplicação do Princípio de Pareto, os países que representam $80 \%$ do Consumo Mundial de carne bovina e $80 \%$ da Produção Mundial de carne bovina.

Tabela 21: Consumo Mundial de Carne Bovina (2011)

\begin{tabular}{|c|c|c|c|}
\hline Grupos & País & Consumo (ton) & Representatividade (\%) \\
\hline \multirow{3}{*}{$\begin{array}{c}\text { Grandes } \\
\text { Consumidores }\end{array}$} & EUA & $11.664 .579,46$ & $18,02 \%$ \\
\hline & Brasil & 7.693.956,86 & $11,89 \%$ \\
\hline & China & $6.725 .470,54$ & $10,39 \%$ \\
\hline \multirow{24}{*}{$\begin{array}{c}\text { Médios } \\
\text { Consumidores }\end{array}$} & Rússia & $2.329 .790,14$ & $3,60 \%$ \\
\hline & Argentina & $2.237 .735,30$ & $3,46 \%$ \\
\hline & México & $1.914 .965,83$ & $2,96 \%$ \\
\hline & França & $1.612 .051,72$ & $2,49 \%$ \\
\hline & Paquistão & $1.512 .969,29$ & $2,34 \%$ \\
\hline & Índia & $1.500 .967,65$ & $2,32 \%$ \\
\hline & Itália & $1.307 .517,98$ & $2,02 \%$ \\
\hline & Reino Unido & $1.175 .654,18$ & $1,82 \%$ \\
\hline & Japão & $1.140 .572,13$ & $1,76 \%$ \\
\hline & Alemanha & $1.107 .926,78$ & $1,71 \%$ \\
\hline & Egito & $1.045 .473,12$ & $1,62 \%$ \\
\hline & Canadá & $1.025 .993,62$ & $1,59 \%$ \\
\hline & Austrália & $922.539,33$ & $1,43 \%$ \\
\hline & África do Sul & $822.537,98$ & $1,27 \%$ \\
\hline & Colômbia & $799.629,77$ & $1,24 \%$ \\
\hline & Uzbequistão & $763.387,79$ & $1,18 \%$ \\
\hline & Turquia & $755.217,46$ & $1,17 \%$ \\
\hline & Coréia & $712.222,71$ & $1,10 \%$ \\
\hline & Vietnã & $644.734,03$ & $1,00 \%$ \\
\hline & Espanha & $606.225,46$ & $0,94 \%$ \\
\hline & Indonesia & $600.547,93$ & $0,93 \%$ \\
\hline & Venezuela & $595.122,17$ & $0,92 \%$ \\
\hline & Quênia & $457.915,10$ & $0,71 \%$ \\
\hline & Ucrânia & $387.930,06$ & $0,60 \%$ \\
\hline Outros & 147 Países & $13.877 .829,09$ & $20,00 \%$ \\
\hline
\end{tabular}

Fonte: (FAO, 2014a) 
Na tabela 22 é possível notar que realizando a divisão dos $80 \%$ do consumo mundial bovino entre os continentes, Américas (Norte e Sul) são responsáveis por 36\% (19\% da América Latina), Ásia 32\%, Europa 10\%, Oceania 1\% e África 1\%.

Segundos estimativas da World Agricultural Forum - WAF (entidade sem fins lucrativos de pesquisa da agricultura nos EUA), os países em desenvolvimento devem concentrar o crescimento da produção e do consumo de carne bovina até o início da próxima década. (ANICS, 2014b).

Com respeito à América Latina, o destaque acentuado em números de consumo e produção podem ser reflexos de algumas estimativas da FAO, que corroboram com ações do Conselho Latino-Americano de Proteína Animal - COLAPA. De acordo com algumas estimativas da FAO para os anos de 2012-2014, 805 milhões de pessoas sofrem com a fome no mundo. Porém esse número foi reduzido em mais de 100 milhões na última década e são 209 milhões a menos do que em 1990-1992. Na América Latina e no Caribe, o problema afeta 37 milhões de pessoas (6,1\% da população) um avanço significativo, considerando que 68,5 milhões de pessoas (15,3\%) sofriam com a fome no triênio de 1990-1992. Isso se deve a ações de países da América Latina e do Caribe, que em conjunto reduziram em $60 \%$ a proporção da população subalimentada, tornando-se a única região do mundo a conseguir atingir a meta de reduzir à metade a porcentagem de pessoas que sofrem com a fome. O COLAPA tem como prioridade promover de forma proativa os benefícios da proteína animal, impulsionar sua produção e fomentar seu consumo e dessa forma, contribuir para combater a fome e a desnutrição, cuidando dos recursos naturais com uma produção sustentável de proteína animal. (AGROLINK, 2015; FAO, 2016).

Os países da Ásia estão entre os maiores importadores das carnes bovinas brasileiras. O continente asiático reúne países, que em sua maioria, não possuem os recursos naturais necessários para abastecer seu incremento de demanda por carne bovina. Dessa forma, a proximidade entre os países leva a crer que um principal exportador para a Ásia - a Índia. (ANICS, 2014a). Um dado sobre a Índia que pode ser destacado é o aumento do consumo de carne bovina na última década. A mudança de cultura alimentar no país é uma questão que tem gerado repercussão mundial, pois de forma hipotética é atribuída ao aumento do poder aquisitivo, junto com a redução do número de habitantes que vivem sob uma dieta vegetariana (e que de certa forma, quebraram tabus e restrições religiosas). Uma pesquisa realizada pelo 
Centre for the Study of Developing Societies - CSDS, identificou que apenas 31\% dos indianos são realmente vegetarianos e grande parte dos indianos têm consumido alimentos provenientes de redes de fast food, que utilizam em seu cardápio diferentes itens gerados a partir de carne bovina. (OPERA MUNDI, 2015).

Na Europa em 2013, a população foi afetada pela intitulada "Fraude da Carne de Cavalo", em que fabricantes de produtos prontos (congelados) foram investigados por produzirem alimentos com substituição irregular de carne bovina pela equina. Segundo o Ministério da Agricultura francês, esse incidente gerou desconfiança no consumo pela população e ao mesmo tempo a inclusão de legislação mais criteriosa e maior tributação para a importação. (FOLHA, 2013).

De acordo BARCELLOS, M. D. (2007), na Oceania, e especificamente na Austrália, é possível notar mudanças nos hábitos alimentares ocorridas nos últimos 40 anos. Entre as diversas razões podem-se citar influências culturais (impactada especialmente pelos imigrantes, que já representam 24\% da população), aspectos ligados à saúde (preocupação com obesidade, colesterol, entre outros), alteração nos preços dos alimentos, ações e marketing e etc.

Segundo a ABIEC (2012), o continente africano tem apresentado crescimento da demanda por carne bovina, especialmente notado nos últimos 10 anos. A África tem enfrentado uma seca severa ocasionada pelo fenômeno do El Niño, e que tem afetado a produção pecuária na maioria dos países africanos, como África do Sul, Zimbábue, Zâmbia, Malavi e outros, levando à escassez de carne e outros produtos e elevado a importação, em especial de carne brasileira para o consumo da população. (BEEFPOINT, 2016a).

Ao se fazer a divisão dos $80 \%$ de produção mundial bovina entre os continentes (indicada na tabela 23), nota-se que Américas (Norte e Sul) são responsáveis por 42\% (23\% da América Latina), Ásia 24\%, Europa 9\%, Oceania 4\% e África 1\%. Especificamente na América Latina são $23 \%$ da produção mundial. 
Tabela 22: Produção Mundial de Carne Bovina (2011)

\begin{tabular}{|c|c|c|c|}
\hline Grupos & País & Produção (ton) & Representatividade (\%) \\
\hline \multirow{3}{*}{$\begin{array}{c}\text { Grandes } \\
\text { Produtores }\end{array}$} & EUA & $11.921 .102,00$ & $19,02 \%$ \\
\hline & Brasil & $9.030 .000,00$ & $14,40 \%$ \\
\hline & China & $6.182 .155,00$ & $9,86 \%$ \\
\hline \multirow{24}{*}{$\begin{array}{c}\text { Médios } \\
\text { Produtores }\end{array}$} & Argentina & $2.498 .954,00$ & $3,99 \%$ \\
\hline & Austrália & $2.128 .285,00$ & $3,40 \%$ \\
\hline & México & $1.803 .932,00$ & $2,88 \%$ \\
\hline & Rússia & $1.625 .469,00$ & $2,59 \%$ \\
\hline & França & $1.566 .453,00$ & $2,50 \%$ \\
\hline & Alemanha & $1.170 .376,00$ & $1,87 \%$ \\
\hline & Canadá & $1.140 .980,00$ & $1,82 \%$ \\
\hline & Itália & $1.000 .374,00$ & $1,60 \%$ \\
\hline & Índia & $984.718,00$ & $1,57 \%$ \\
\hline & Reino Unido & $936.000,00$ & $1,49 \%$ \\
\hline & África do Sul & $828.609,00$ & $1,32 \%$ \\
\hline & Colômbia & $820.985,00$ & $1,31 \%$ \\
\hline & Paquistão & $761.000,00$ & $1,21 \%$ \\
\hline & Uzbequistão & $667.500,00$ & $1,06 \%$ \\
\hline & Turquia & $644.906,00$ & $1,03 \%$ \\
\hline & Nova Zelândia & $622.676,00$ & $0,99 \%$ \\
\hline & Espanha & $604.113,00$ & $0,96 \%$ \\
\hline & Irlanda & $545.942,00$ & $0,87 \%$ \\
\hline & Japão & $500.370,00$ & $0,80 \%$ \\
\hline & Venezuela & $488.653,00$ & $0,78 \%$ \\
\hline & Indonésia & $485.335,00$ & $0,77 \%$ \\
\hline & Uruguai & $479.000,00$ & $0,76 \%$ \\
\hline & Quênia & $458.000,00$ & $0,73 \%$ \\
\hline & Egito & $454.484,00$ & $0,72 \%$ \\
\hline Outros & 180 Países & $13.877 .829,09$ & $20,00 \%$ \\
\hline
\end{tabular}

Fonte: (FAO, 2014a)

Segundo a WAF, 80\% do crescimento da produção de carne até 2022, ou 43 milhões de toneladas, virão de países em desenvolvimento. Do lado do consumo, 92\% do crescimento virão da Ásia (40\%), América Latina (30\%) e África (22\%). Os vetores do crescimento na demanda por carne bovina serão Brasil e China, com 1,4 milhão e 1,2 milhão de toneladas, respectivamente, de incremento na demanda entre 2011 e 2022. (ANICS, 2014b).

Apesar do bom desempenho demonstrado pela pecuária bovina de corte no Brasil, o país ainda enfrenta restrições em uma série de importantes mercados, em razão de barreiras protecionistas que impossibilitam o pleno desenvolvimento do mercado de exportação. As barreiras sanitárias 
são um exemplo de barreira para as exportações brasileiras de carne em formato in natura. Em vista disso, o país criou, em parceria com o Ministério da Agricultura, Pecuária e Abastecimento - MAPA, a Agência de Promoção de Exportações e Investimentos - APEX, a Confederação Nacional da Agricultura - CNA e a Associação Brasileira das Indústrias Exportadoras de Carne Bovina - ABIEC, o Brazilian Beef - Programa da Carne Brasileira, com o objetivo de apresentar as características da carne bovina aos mercados internacionais, juntamente com seu programa de medidas no controle de doenças. O programa está colhendo frutos iniciais, com perspectivas de um aumento nas exportações em um futuro próximo. (BARCELLOS, M. D., 2007).

Em contrapartida, a preocupação de mais de 200 representantes de governo, sociedade civil, academia e associações de produtores pecuários de 50 países, durante o encontro Agenda Global para a Pecuária Sustentável, ocorrido no Panamá, é a proteção dos recursos naturais que sustentam a segurança alimentar, visto que a estimativa da FAO é de que a demanda por produtos de origem animal sofra $70 \%$ de aumento até 2050 . Com isso em mente, foi assinada a Declaração do Panamá, a qual contempla Objetivos do Desenvolvimento Sustentável (ODS), com vistas à redução de degradação ambiental. (ONUBR, 2016).

Os problemas de sanidade animal enfrentados mundialmente nos últimos anos, e a mudança comportamental causada pelas consequências dos processos de globalização tem levado a um crescente movimento de organizações não-governamentais - ONGs posicionando-se contra a produção intensiva de carne, contra a poluição e contra o desmatamento de florestas e preocupadas com o bem-estar animal e com a sustentabilidade da produção agrícola e animal. Muitas dessas ONGs são ainda totalmente contra o consumo de carne estimulando o vegetarianismo (exemplos: www.themeatrix.com; www.factoryfarm.org; www.veggieglobal.com).

\subsection{Consumo de Carne Bovina: relação com a população e Pib per capita}

De acordo com a FAO (2013), o crescimento da população em centros urbanos, aliado ao aumento de renda dos trabalhadores, fará com que a demanda por aves, bovinos, suínos e ovinos cresça em ritmo maior do que a por produtos agrícolas até 2023. Além disso, o índice de insegurança alimentar no mundo vem diminuindo a cada ano, com milhões de pessoas saindo da linha da pobreza e passando a consumir carne, leite, ovos e derivados. (FAO et al., 2014). Nesse caso, subtende-se uma associação das variáveis população e Renda (considerado como 
Pib per capita) ao consumo. Com base nisso, foi realizada uma análise de regressão múltipla entre as variáveis e a tabela 26 indica os resultados da associação de consumo per capita ao Pib per capita.

Tabela 23: Regressão Múltipla - Consumo per capita e Pib per capita (1980-2011)

\begin{tabular}{|c|c|c|c|}
\hline Grupos & País & $\mathbf{R}^{\mathbf{2}}$ & Equação \\
\hline \multirow{3}{*}{$\begin{array}{c}\text { Grandes } \\
\text { Consumidores }\end{array}$} & EUA & 0,764 & $y=-6,269 \ln (x)+108,48$ \\
\hline & Brasil & 0,815 & $y=8,5062 \ln (x)-37,845$ \\
\hline & China & 0,919 & $y=3,3072 \ln (x)-16,584$ \\
\hline \multirow{24}{*}{$\begin{array}{c}\text { Médios } \\
\text { Consumidores }\end{array}$} & Rússia & 0,057 & $y=-1,293 \ln (x)+30,277$ \\
\hline & Argentina & 0,446 & $y=-13,07 \ln (x)+174,28$ \\
\hline & México & 0,475 & $y=2,4497 \ln (x)-5,2236$ \\
\hline & França & 0,610 & $y=-4,394 \ln (x)+71,88$ \\
\hline & Paquistão & 0,861 & $y=2,718 \ln (x)-10,455$ \\
\hline & Índia & 0,885 & $y=-0,602 \ln (x)+5,6933$ \\
\hline & Itália & 0,395 & $y=-1,675 \ln (x)+41,933$ \\
\hline & Reino Unido & 0,213 & $y=-1,233 \ln (x)+33,086$ \\
\hline & Japão & 0,750 & $y=3,2213 \ln (x)-24,275$ \\
\hline & Alemanha & 0,747 & $y=-7,547 \ln (x)+93,387$ \\
\hline & Egito & 0,536 & $y=3,2304 \ln (x)-13,296$ \\
\hline & Canadá & 0,859 & $y=-7,097 \ln (x)+106,56$ \\
\hline & Austrália & 0,498 & $y=-6,81 \ln (x)+111,16$ \\
\hline & África do Sul & 0,051 & $y=-1,949 \ln (x)+32,549$ \\
\hline & Colômbia & 0,230 & $y=-1,328 \ln (x)+28,013$ \\
\hline & Uzbequistão & 0,378 & $y=4,8262 \ln (x)-11,156$ \\
\hline & Turquia & 0,020 & $y=0,2809 \ln (x)+3,7187$ \\
\hline & Coréia & 0,208 & $y=2,3309 \ln (x)-11,345$ \\
\hline & Vietnã & 0,520 & $y=1,2633 \ln (x)-4,5304$ \\
\hline & Espanha & 0,625 & $y=1,7687 \ln (x)-3,4023$ \\
\hline & Indonesia & 0,710 & $y=0,3337 \ln (x)-0,3552$ \\
\hline & Venezuela & 0,052 & $y=3,0505 \ln (x)-5,7879$ \\
\hline & Quênia & 0,470 & $y=1,9126 \ln (x)-1,5033$ \\
\hline & Ucrânia & 0,102 & $y=-2,478 \ln (x)+31,286$ \\
\hline
\end{tabular}

Fonte: desenvolvido pela autora com base em FAO (2014a); WORLD BANK (2014e)

Conforme esclarecido no capítulo 9, a regressão múltipla tem por objetivo analisar relações e além disso, identificar, por meio do coeficiente de regressão $\left(\mathrm{R}^{2}\right)$, o grau de variância (ou de coerência) na variável dependente (consumo), que é explicado pelas variáveis independentes (População e Pib per capita). Dessa forma, quanto maior o $\mathrm{R}^{2}$, maior será o grau de explicação 
da variável dependente. (HAIR JR et al., 2005) Para essa pesquisa, foi considerado o nível de 0,70 como aceitável.

Pelas regressões desenvolvidas, foi possível identificar que o consumo pode ser explicado pela variável Pib per capita em 09 dos 27 países (EUA, Brasil, China, Paquistão, Índia, Japão, Alemanha, Canadá e Indonésia).

Com essa análise, foi possível identificar que 50\% do consumo mundial de carne bovina pode ser explicado pelo Pib per capita. Cada uma das regressões resultou em uma equação, que foi utilizada nas projeções de consumo, exploradas adiante em novos subtítulos dessa pesquisa.

\subsection{Tendência de Consumo Global de Carne Bovina}

Uma vez que grande parte do consumo de carne bovina é associado e pode ser explicado pelo nível de Pib per capita, foi realizada uma análise de tendência global de consumo bovino per capita em função do Pib per capita.

Figura 35: Tendência Global de Consumo em função do Pib per capita

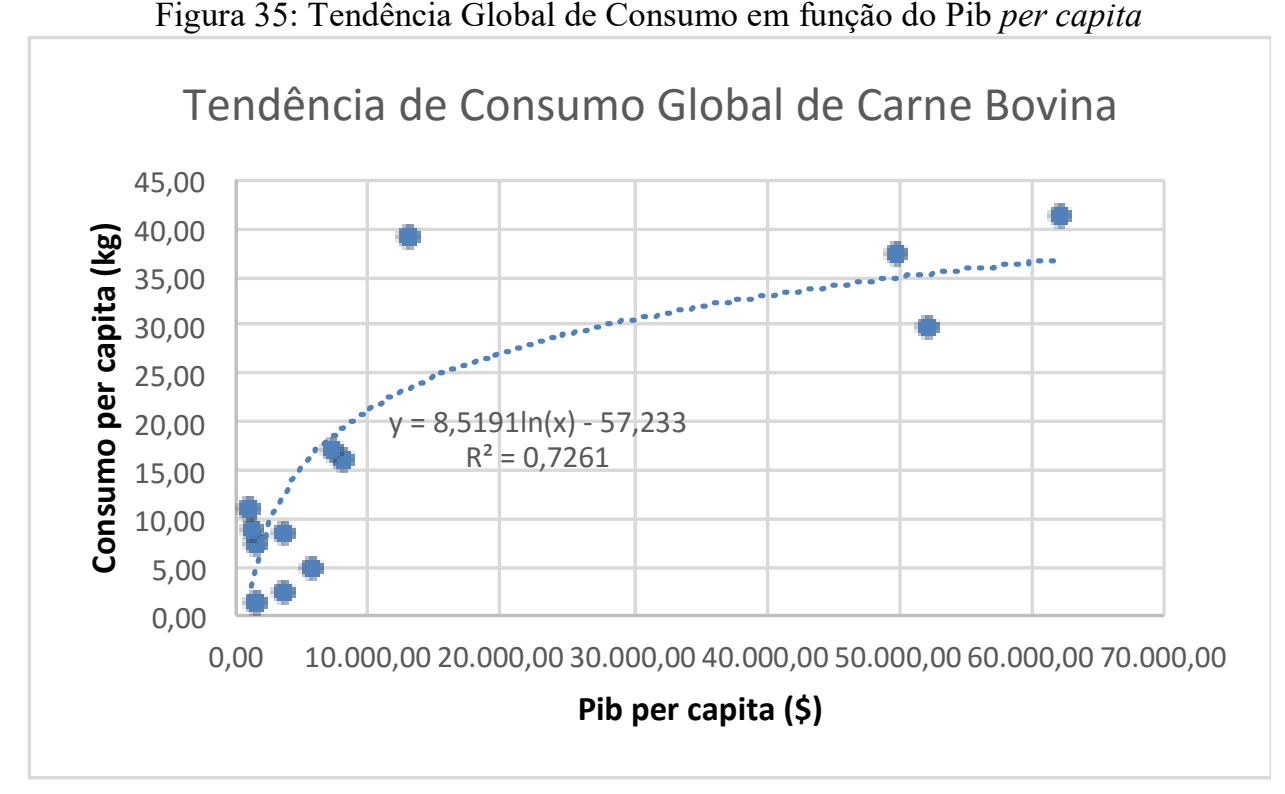

Fonte: (FAO, 2014a)

Inicialmente análises gerais (que envolviam todos os países analisados) foram realizadas e percebeu-se que o coeficiente de regressão situava-se abaixo do nível aceitável. Dessa forma, a análise foi realizada excluindo os países que não apresentaram associação do consumo per capita ao Pib per capita. 


\subsection{Modelo de Produção e Consumo Sustentável de Carne Bovina}

Uma vez que o objetivo principal dessa pesquisa é identificar o nível de produção e consumo global sustentável de carne bovina, a construção do modelo da pesquisa foi iniciada á partir da identificação da Biocapacidade (gha) dos países analisados, seguida pelos constructos, destacados na figura 34 da pesquisa.

Considerando como premissa que Biocapacidade (Bi) se refere aos Recursos Naturais disponíveis no meio ambiente para pecuária, o modelo de Produção e Consumo Sustentável de Carne Bovina, desenvolvido nessa pesquisa a partir da metodologia EF, pode ser descrito pelas equações:

Quadro 3: Equações da Tese

Eficiência no Uso de Recursos Naturais (Er) = Biocapacidade (Bi) / Demanda (De)

Ou de uma forma mais complexa:

$$
\mathrm{Er}=\mathrm{Bi} / \mathrm{De}
$$

Produção Máxima Sustentável $($ Pm) = Biocapacidade (Bi) / Eficiência no Uso de

$$
\text { Recursos Naturais (Er) }
$$

Ou de uma forma mais complexa:

$$
\mathrm{Pm}=\mathrm{Bi} / \mathrm{Er}
$$

Ecological Footprint (Ef) = Eficiência no Uso de Recursos Naturais (Er) * Demanda

$$
\text { (De) }
$$

Ou de uma forma mais complexa:

$$
\mathrm{Ef}=\mathrm{Er} * \mathrm{De}
$$

Consumo e Produção Sustentável (Cps) = Biocapacidade $($ Bi) - Ecological Footprint

$$
(E f)=0
$$

Ou de uma forma mais complexa:

$$
\mathrm{Cps}=\mathrm{Bi}-\mathrm{Ef}=0
$$

Fonte: desenvolvido pela autora 


\subsection{Simulações do Modelo Sustentável de Carne Bovina para 2040}

A partir do modelo mencionado no subtítulo 10.4, 4 simulações foram desenvolvidas a fim de identificar as mudanças na Biocapacidade e as medidas a serem tomadas para o equilíbrio ou o alcance da sustentabilidade no consumo e produção global de carne bovina.

As simulações desenvolvidas encontram-se nos apêndices B-E e deram origem aos 4 cenários prospectivos explicitados a partir de agora nessa pesquisa.

\subsection{Cenários de Produção e Consumo Sustentável de Carne Bovina}

A partir das simulações desenvolvidas no subtítulo 10.5 dessa pesquisa, foram desenvolvidos cenários prospectivos para 2040, com especial enfoque no Brasil e no seu papel para a produção mundial, a fim de prever o futuro do consumo e produção global de carne bovina. Cada um dos cenários apresenta em seu título a principal característica do cenário.

Conforme salientado no capítulo 9, para essa pesquisa foram elaborados os cenários mediante a aplicação da metodologia desenvolvida por WRIGHT, J. T. C.; SPERS (2006), em que são descritas três possibilidades de visões do futuro: a visão extrapolativa, exploratória e normativa, seguindo as etapas descritas a seguir.

1. Definição do escopo e objetivos dos cenários: O escopo dos cenários deve permear a produção e o consumo mundial sustentável de carne bovina, com o objetivo de identificar um padrão sustentável, através da combinação do uso de recursos naturais, variáveis econômicas, tendências tecnológicas e padrões globais de consumo de alimentos.

2. Identificação das variáveis, tendências e eventos fundamentais: Uma vez definido o escopo e os objetivos dos cenários de Produção e Consumo Mundial Sustentável de Carne Bovina, e fazendo uma análise do panorama atual do setor, foi possível identificar uma lista das principais variáveis dos cenários: (1) Pib per capita; (2) Consumo e Padrão Alimentar da População; (3) Sustentabilidade e uso de recursos naturais; (4) Impactos causados pela pecuária ao meio ambiente; (5) Tecnologia na pecuária bovina de corte. 
3. Estruturação das variáveis dos cenários: Neste sentido foi possível identificar fatores invariantes relevantes para Produção e o Consumo Mundial de Carne Bovina, como o crescimento populacional e Pib per capita, bem como a associação dessas variáveis ao consumo, sendo considerada uma forte influência no setor.

A divisão de variáveis foi desenvolvida com base na técnica de Análise e Estruturação de Modelos, desenvolvida por WRIGHT, J. (1991) :

- Variáveis resultantes: redução contínua na biocapacidade, desmatamento.

- Variáveis intermediárias: emissão de gases poluentes, desmatamento, poluição de solo.

- Variáveis causais: aumento do Pib per capita, diversidade de consumo de carne, crescimento populacional.

4. Projeção dos estados futuros das variáveis: A técnica utilizada nessa etapa foi a simulação, fazendo uso de dados qualitativos e quantitativos. As simulações, explicitadas nos apêndices B-E, foram realizadas a partir do modelo desenvolvido nessa pesquisa.

5. Identificação dos temas motrizes: A partir das simulações realizadas na etapa anterior, foram definidos 5 temas motrizes:

- Cenário mais provável: Cenário Atual

- Cenário contrastado 1: Cenário 2040 com Tecnologia Atual

- Cenário contrastado 2: Cenário 2040 com Tecnologia Moderada

- Cenário desejado: Cenário 2040 com Tecnologia em busca da Sustentabilidade

6. Montagem de uma matriz morfológica de cenários: Foi realizada uma análise, juntamente com a combinação consistente entre todas as variáveis dos cenários, gerando uma matriz dos cenários, que serviu de base para a redação dos cenários para a Produção e Consumo Mundial Sustentável de Carne Bovina em 2040, indicada na tabela 25. 
Tabela 24: Matriz Morfológica dos Cenários para 2040

\begin{tabular}{|c|c|c|c|c|}
\hline Variáveis & $\begin{array}{c}\text { Cenário mais provável: } \\
\text { Cenário Atual }\end{array}$ & $\begin{array}{c}\text { Cenário contrastado 1: } \\
\text { Cenário com Tecnologia } \\
\text { Atual }\end{array}$ & $\begin{array}{c}\text { Cenário contrastado 2: } \\
\text { Cenário com Tecnologia } \\
\text { Moderada }\end{array}$ & $\begin{array}{l}\text { Cenário desejado: } \\
\text { Cenário } 2040 \text { com } \\
\text { Tecnologia em busca da } \\
\text { Sustentabilidade }\end{array}$ \\
\hline Pib per capita & $\begin{array}{l}\text { O Pib per capita nesse cenário } \\
\text { é o apurado em } 2011 \text { e de } \\
\text { acordo com as análises } \\
\text { estatísticas, ele exerce } \\
\text { influência no consumo de } \\
\text { carne bovina. }\end{array}$ & $\begin{array}{l}\text { O Pib per capita nesse } \\
\text { cenário é o projetado } \\
\text { para } 2040 \text { e de acordo } \\
\text { com as análises } \\
\text { estatísticas, ele exerce } \\
\text { influência no consumo } \\
\text { de carne bovina. }\end{array}$ & $\begin{array}{l}\text { O Pib per capita nesse } \\
\text { cenário é o projetado } \\
\text { para } 2040 \text { e de acordo } \\
\text { com as análises } \\
\text { estatísticas, ele exerce } \\
\text { influência no consumo } \\
\text { de carne bovina. }\end{array}$ & $\begin{array}{l}\text { O Pib per capita nesse } \\
\text { cenário é o projetado } \\
\text { para } 2040 \text { e de acordo } \\
\text { com as análises } \\
\text { estatísticas, ele exerce } \\
\text { influência no consumo } \\
\text { de carne bovina. }\end{array}$ \\
\hline $\begin{array}{l}\text { Consumoe } \\
\text { Padrão } \\
\text { Alimentar da } \\
\text { População }\end{array}$ & $\begin{array}{c}\text { O consumo pela população é o } \\
\text { apurado em } 2011 .\end{array}$ & $\begin{array}{l}\text { O consumo nesse } \\
\text { cenário é projetado com } \\
\text { base na equação que } \\
\text { explica o consumo } \\
\text { associado ao Pib per } \\
\text { capita dos países. }\end{array}$ & $\begin{array}{r}\text { O con } \\
\text { cenário é } \\
\text { base na } \\
\text { explica } \\
\text { associa } \\
\text { capita }\end{array}$ & $\begin{array}{r}\text { O co } \\
\text { cenário } \\
\text { base } r \\
\text { expli } \\
\text { assoc } \\
\text { capi }\end{array}$ \\
\hline $\begin{array}{l}\text { Sustentabilida } \\
\text { de e uso de } \\
\text { recursos } \\
\text { naturais }\end{array}$ & $\begin{array}{l}\text { A sustentabilidade no uso de } \\
\text { recursos é medida com base } \\
\text { na biocapacidade e produção } \\
\text { realizada em } 2011 .\end{array}$ & $\begin{array}{l}\text { A sustentabilidade no } \\
\text { uso de recursos é } \\
\text { medida pela } \\
\text { biocapacidade e } \\
\text { demanda projetada para } \\
2040 .\end{array}$ & $\begin{array}{r}\text { A susten } \\
\text { uso de } \\
\text { med } \\
\text { biocap } \\
\text { demanc } \\
\text { par }\end{array}$ & $\begin{array}{r}\text { A sustent } \\
\text { uso de } r \\
\text { medi } \\
\text { biocap } \\
\text { demanda p } \\
2\end{array}$ \\
\hline $\begin{array}{c}\text { Impactos } \\
\text { causados pela } \\
\text { pecuária ao } \\
\text { meio } \\
\text { ambiente }\end{array}$ & $\begin{array}{c}\text { Os impactos identificados } \\
\text { nesse cenário são medidos } \\
\text { através da EF medida no ano } \\
\text { de } 2011 .\end{array}$ & $\begin{array}{l}\text { Os impactos causados } \\
\text { pela pecuária bovina } \\
\text { nesse cenário são } \\
\text { identificados pela } \\
\text { medição da EF, que se } \\
\text { baseará na eficiência de } \\
\text { recursos naturais no uso } \\
\text { da biocapacidade na } \\
\text { demanda projetada. }\end{array}$ & $\begin{array}{l}\text { Os impactos causados } \\
\text { pela pecuária bovina } \\
\text { nesse cenário são } \\
\text { identificados pela } \\
\text { medição da EF, que se } \\
\text { baseará na eficiência de } \\
\text { recursos naturais no uso } \\
\text { da biocapacidade na } \\
\text { demanda projetada. }\end{array}$ & $\begin{array}{l}\text { Os impactos causados } \\
\text { pela pecuária bovina } \\
\text { nesse cenário são } \\
\text { identificados pela } \\
\text { medição da EF, que se } \\
\text { baseará na eficiência de } \\
\text { recursos naturais no uso } \\
\text { da biocapacidade na } \\
\text { demanda projetada. }\end{array}$ \\
\hline $\begin{array}{l}\text { Tecnologia na } \\
\text { pecuária } \\
\text { bovina de } \\
\text { corte }\end{array}$ & $\begin{array}{l}\text { A tecnologia identificada nesse } \\
\text { cenário é no uso de } \\
\text { biocapacidade por tonelada de } \\
\text { carne produzida em } 2011 .\end{array}$ & $\begin{array}{c}\text { É considerado que nesse } \\
\text { cenário a tecnologia ou } \\
\text { eficiência no uso de } \\
\text { recursos por tonelada } \\
\text { ocorra no mesmo ritmo } \\
\text { de } 2011 .\end{array}$ & $\begin{array}{c}\text { A tecnologia nesse } \\
\text { cenário tem papel } \\
\text { moderado no equilíbrio } \\
\text { entre a EF e a } \\
\text { Biocapacidade de } \\
\text { Recursos. }\end{array}$ & $\begin{array}{c}\text { A tecnologia nesse } \\
\text { cenário tem por objetivo } \\
\text { proporcionar o } \\
\text { equilibrio entre a EF e a } \\
\text { Biocapacidade de } \\
\text { Recursos. }\end{array}$ \\
\hline
\end{tabular}

Fonte: desenvolvido pela autora

7. Redação e validação dos cenários: No subtítulo 10.6 .1 foi desenvolvida a redação dos cenários, juntamente com a validação por especialistas do setor e análise. A análise da validação dos cenários foi realizada por meio das variáveis definidas nos cenários.

8. Elaboração dos cenários de transição ou de planejamento: A elaboração de cenários foi realizada, de acordo com as etapas do modelo selecionado, que permitiram a construção de cenários de curto e médio prazo, coerentes com os cenário de longo prazo propostos inicialmente. 


\subsubsection{Cenário 1: Cenário Atual - 2011}

A simulação utilizada como base para o desenvolvimento do cenário 1 encontra-se no apêndice B.

Esse cenário tem como referência a mensuração do dados de população, consumo per capita, Pib per capita, EF, Produção, Área para Pecuária, Biocapacidade e Biocapacidade por tonelada do ano de 2011.

É possível perceber que de forma geral, há uma reserva de biocapacidade de 181 milhões de Gha, atribuída especialmente pela Austrália, Argentina, Brasil e África do Sul. Em contrapartida, há países em situação de alto déficit de biocapacidade, com especial destaque para China, Itália, Japão, que somados proporcionam um déficit de 66 milhões de Gha.

Uma informação de suma importância nesse cenário é a Biocapacidade utilizada por tonelada produzida de carne, definida no modelo da pesquisa como Eficiência no Uso de Recursos Naturais. Os países que utilizam os menores níveis de Biocapacidade são Coréia, Paquistão, Japão, Itália e Vietnã.

Embora o Brasil possua uma destacada reserva de biocapacidade, sua Eficiência no Uso de Recursos Naturais é a $10^{\mathrm{a}}$ pior dos países analisados. Isso indica que há possibilidade de melhoria tecnológica que proporcione aumento de eficiência e consequentemente, maior produtividade. .

É de destaque também a Austrália e Argentina, que possuem alta reserva de Biocapacidade, mas com situação similar ao Brasil - baixa eficiência produtiva. A Austrália possui grande potencial, porém devido à seca sofrida na região, o solo ficou debilitado e isso ocasionou perda no banco natural de sementes de pastagens, dificultando o aumento da pecuária de corte e promovendo uma estagnação do setor no país.

Dessa forma, subtende-se que há oportunidade para melhoria na eficiência e aumento de produtividade, o que pode contribuir com a competitividade do país e aumento de posições entre os produtores globais de carne bovina. 


\subsubsection{Cenário 2: Cenário 2040 com Tecnologia Atual}

A simulação utilizada como base para o desenvolvimento do cenário 2 encontra-se no apêndice C.

As projeções indicam que haverá aumento da população e redução do nível de pobreza mundial, o que poderá ocasionar no aumento do consumo de alimentos em países em desenvolvimento e subdesenvolvidos. Países asiáticos altamente populosos como a China e a Índia levarão ao aumento substancial no consumo de proteínas animais, em especial a carne bovina. Porém, ao mesmo tempo que o consumo é ajustado, os ecossistemas precisam ser preservados, ou seja, é necessário aumentar a produção sem impactar o ambiente.

Pesquisas recentes da Embrapa indicam que o aumento da demanda por carne bovina brasileira está vinculado à preservação dos recursos naturais. (BALBINO et al., 2011). Assim, toneladas de carne serão produzidas com alta produtividade de modo a não impactar negativamente o ambiente em que o animal está inserido, utilizando a terra e a água de maneira racional e integrando a produção animal ao ecossistema existente. $\mathrm{O}$ desafio da produção bovina brasileira e mundial é aumentar a produtividade e o rebanho, sem ampliar a área disponível para produção e para isso a tecnologia exerce um importante papel.

A degradação de pastagens é um dos principais sinais da baixa sustentabilidade da pecuária, nas diferentes regiões brasileiras e mundiais. O manejo inadequado do rebanho é considerado como a principal causa dessa degradação e entre os principais problemas da pecuária brasileira, estão a degradação das pastagens e dos solos; o manejo animal inadequado; a baixa reposição de nutrientes no solo; os impedimentos físicos dos solos; e os baixos investimentos tecnológicos. Essas restrições trazem como consequências negativas: a baixa oferta de forragens, baixos índices zootécnicos e baixa produtividade de carne por hectare, além de reduzido retorno econômico e ineficiência do sistema.

A tecnologia atual mais utilizada envolve a aplicação de sistemas de produção integrados (lavoura-pecuária ou pecuária-floresta ou lavoura-pecuária-floresta), que diversificam a produção e maximizam o uso da terra, aumentando a rentabilidade da área. 
Dentro desse cenário, foram projetados os devidos crescimentos de população, Pib per capita e Consumo per capita equiparado ao Pib per capita, permanecendo estática a Biocapacidade disponível para pecuária e mantendo a mesma Eficiência no Uso de Recursos Naturais, considerando dessa forma que não haverá avanços tecnológicos em 2040, mas serão mantidos os mesmos processos e sistemas produtivos atuais.

O resultado da estagnação tecnológica é perceptível nesse cenário através de um grave desequilíbrio na biocapacidade global, ocasionando um déficit de 413 milhões de Gha, atribuído especialmente a China (responsável por 330 milhões de Gha), Brasil (com 36 milhões de Gha) e Rússia (com 22 milhões de Gha).

Dessa forma, é possível entender que mediante as projeções realizadas, a estagnação tecnológica na pecuária bovina traz graves impactos ao meio ambiente e torna sua produção e consumo insustentável ecologicamente.

\subsubsection{Cenário 3: Cenário 2040 com Avanço Tecnológico Moderado}

A simulação utilizada como base para o desenvolvimento do cenário 3 encontra-se no apêndice D.

Nesse cenário são projetados os devidos crescimentos de população, Pib per capita e Consumo per capita equiparado ao Pib per capita, permanecendo estática a Biocapacidade disponível para pecuária e acrescentando $10 \%$ ao nível de Eficiência no Uso de Recursos Naturais de cada um dos países.

Estudiosos argumentam que algumas das técnicas de eficiência moderada de manejo de pastagens e plantio tem como resultado a melhoria da fertilidade do solo e tende a produzir rendimentos de 30 a 40\%, por animal e por área. Algumas dessas tecnologias envolvem a cobertura e restauração de pasto. E com isso, a técnica de Integração Lavoura-Pecuária-Floresta (iLPF) tem sido uma boa opção em muitos países para avanços tecnológicos moderados na pecuária bovina. (BALBINO et al., 2011)

Por meio desse cenário, é possível identificar que o saldo negativo global de biocapacidade apresenta redução de 67\% (em comparação ao Cenário 2), permanecendo em 277 milhões de 
Gha. E desse saldo negativo, é atribuído a China 283 milhões de Gha, ou seja, a Austrália ainda contribui com um saldo positivo de biocapacidade por volta de 69 milhões de Gha.

Além da China, Rússia, México, Brasil, e Venezuela apresentam contribuições para o déficit em biocapacidade global, totalizando 52 milhões de Gha.

Dessa forma, é possível compreender que mesmo com um avanço moderado tecnológico em 10\% em Eficiência no Uso de Recursos Naturais de cada um dos países, não há mudança para um nível de produção e consumo de carne bovina sustentável.

\subsubsection{Cenário 4: Cenário 2040 com tecnologia em busca da sustentabilidade}

A simulação utilizada como base para o desenvolvimento do cenário 4 encontra-se no apêndice E.

Produzir mais com menos, aplicação da genética para aumento da produtividade e lucratividade dos rebanhos de corte, manejo de pastagens com a iLPF, estratégias para eficiência reprodutiva bovina - são algumas das tecnologias avançadas existentes para a produção bovina. (BALBINO et al., 2011)

Em sistemas intensivos, a suplementação aditivada torna-se uma poderosa arma para explorar ao máximo o potencial genético dos animais, bem como da forragem e do suplemento ofertado. Entre os aditivos disponíveis no mercado, os orgânicos ganham destaque no cenário de produção sustentável, pois atuam de modo eficaz e não impactam o ambiente. O Brasil possui clima predominantemente tropical, que favorece a produção de forragens de qualidade e com alta produtividade nos períodos chuvosos. Os ruminantes são capazes de aproveitar alimentos fibrosos e viverem à base de dietas de forragens e, dessa forma, pode-se produzir carne bovina de maneira sustentável e sem competição direta com alimentação humana. (ALVES, 2015)

A suplementação ganhou importância para todas as categorias animais e em todos os períodos do ano, podendo variar de acordo com os índices produtivos desejados - do mais extensivo, com abate de animais de 48 meses, ao mais técnico, com abate de animais de 24 meses, sendo que este possui maior capacidade de lotação, fazendo o básico: cuida do pasto, suplementa corretamente e oferta água de qualidade. 
Alguns estudiosos assumem que a tecnologia avançada, manejo correto das pastagens, água disponível de qualidade e suplementação orgânica sejam as bases para o sucesso da produção de bovinos a pasto (ALVES, 2015). E dessa forma, o futuro da produção de bovinos de corte no Brasil está vinculado ao aumento na produtividade de maneira sustentável, com integração adequada das tecnologias disponíveis no mercado ao sistema de gestão existente na propriedade, produzindo carne de qualidade, em quantidade e, acima de tudo, preservando os recursos naturais. (ALVES, 2015).

Além disso, o Brasil apresenta uma área agricultável disponível total estimada em 152,5 milhões de hectares ou $17,9 \%$ do território, sendo que destes 62,5 milhões de hectares ou 7,3 \% do território é constituído pela área agricultável já utilizada. Pesquisadores indicam que há um potencial de expansão da agricultura e pecuária, especialmente na região do cerrado, correspondente a 90 milhões de hectares ou 10,5\% do território, correspondente às áreas agricultáveis disponíveis e ainda não utilizadas. Esses dados indicam que o avanço da agricultura e pecuária no Brasil não necessita ocupar reflorestamentos, nem desmatar áreas para o plantio de soja ou qualquer outra cultura, mas utilizar-se de áreas degradadas ou intensificar o cultivo nas áreas já disponíveis para a agricultura já seria suficiente para expandir consideravelmente a agricultura e pecuária no Brasil, aumentando tanto a produção quanto o nível de empregabilidade, além de elevar o volume de exportações. (BARROS; HAUSKNECHT, 2005; FAO, 2014b).

Esse cenário prevê a aplicação de avançada tecnologia, que até então é mencionada e considerada, mas pouco aplicada de forma efetiva na pecuária bovina de corte no Brasil e no Mundo para o alcance da sustentabilidade. No cenário é identificado que seria necessário acrescentar 30\% ao nível de Eficiência no Uso de Recursos Naturais de cada um dos países para a busca da sustentabilidade.

Em meio a um cenário sustentável global, a China ainda apresenta grave déficit de biocapacidade, em 186 milhões de Gha, que é balanceado pelas reservas de Austrália, Brasil, EUA, Uruguai, Nova Zelândia, Colômbia e África do Sul, que poderia ser propensos exportadores para atender a demanda projetada da China.

Com a inclusão do avanço tecnológico de $30 \%$ do cenário, há o resultado de Eficiência Sustentável no Uso de Recursos Naturais de cada um dos países. É possível comparar o nível de Eficiência no Uso de Recursos Naturais com tecnologia moderada e avançada e concluir que 
entre os grandes produtores e consumidores, EUA é o país com menor taxa para atingimento da eficiência sustentável com tecnologia avançada.

Com esse cenário, é possível concluir que o nível sustentável global de produção e consumo de carne bovina é factível, desde que ocorram avanços tecnológicos significativos.

\subsubsection{Consolidação dos Cenários}

Nos cenários desenvolvidos, é previsto um aumento considerável da demanda por carne bovina, e a produção continuará liderada pelos EUA, seguida por China, Brasil e Argentina. Segundo RURAL CENTRO (2012), alguns fatores serão os responsáveis pelo impulso da produtividade de carne bovina no futuro:

- Crescimento da população mundial (previsão de cerca de 9 bilhões de pessoas nas próximas décadas);

- $70 \%$ da população se concentra na área urbana e com isso, tem acesso facilitado ao consumo;

- Aumento da renda per capita da população mundial;

- Ocidentalização do consumo, ou seja, mais pessoas consumindo diferentes tipos de carne, especialmente a bovina.

Com base no aumento de demanda previsto, alguns países têm maior potencial para aumentar sua produtividade de carne bovina (BEEFWORLD, 2014; RURAL CENTRO, 2012). O Brasil e uma parte do continente africano têm disponibilidade de área, incidência de chuvas, temperatura, luminosidade e recursos hídricos favoráveis ao aumento da produção. Apenas no Brasil há aproximadamente 333 milhões de hectares que podem ser usados na produção bovina, sem necessidade de desmatamento.

O Brasil continuará como o maior exportador de carne bovina em volume e com baixo custo. Com isso, apesar de seu baixo custo, os pecuaristas brasileiros têm uma das mais baixas taxas de retorno sobre o investimento de gado entre os maiores países exportadores (a frente apenas da África do Sul, Colômbia e Austrália). Isso os levará a um aumento de produção para maior retorno de investimento no volume produzido e negociado, especialmente em questão de exportação, mantendo o mesmo nível de tecnologia utilizado em 2011. 
Nos Estados Unidos, a seca do passado forçou o abate do rebanho de fêmeas e remoção de parte do rebanho do Sul para o Norte por falta d'água. Como consequência, confinadores e indústrias perderam investimentos e a população consumidora está desembolsando alto valor pelo consumo de carne americana. Isso tem feito com que países que importam carne americana reflitam a respeito e se voltem para outros grandes países exportadores, como o Brasil.

$\mathrm{Na}$ China, o custo de produção total de gado sofre variação, pois são empregados diferentes tipos de sistema de engorda. E devido a isso, o retorno de investimento dos produtos também sofre variação. E como consequência, o país continua a se colocar como um grande produtor exportador de carne bovina.

Dessa forma, os cenários preveem um futuro otimista especialmente para o Brasil, em questões econômicas relacionadas ao seu posicionamento como produtor mundial de carne bovina. Analisando pela óptica sustentável, o cenário prevê reservas reduzidas de biocapacidade em alguns países produtores, e aumento contínuo no déficit em sua maioria e em especial ao Brasil, que caso desenvolva uma estratégia para se tornar o maior produtor e aproveitar as oportunidades que surjam para exportação nos países com dificuldade produtiva, terá aumento expressivo de déficit e por conseguinte, alto nível de produção não sustentável. Em contrapartida, caso adicione significativos avanços tecnológicos em sua produção, torna-se uma das produções globais mais sustentáveis, com reservas de biocapacidade.

\subsection{Validação e Análise dos cenários}

De acordo com a metodologia de elaboração de cenários selecionada para essa pesquisa, uma das etapas consiste na validação dos cenários desenvolvidos. (WRIGHT, J. T. C.; SPERS, 2006) Essa validação foi realizada através de entrevistas, conduzidas por meio de questionário estruturado (detalhado no capítulo de metodologia). A seguir estão as respostas dos entrevistados, as quais foram analisadas em conjunto, questão a questão. 


\section{Questão 1- Quais são as principais dificuldades da produção bovina de corte no Brasil e no} Mundo?

Respondente 1: Interações entre as variáveis climáticas e econômicas. Em todos os países são observadas adversidades climáticas sazonais, comprometendo a oferta de forrageiras durante o inverno (cito: estação seca no Brasil, e neve nos EUA). Embora inúmeras são as alternativas à alimentação dos rebanhos nos periodos críticos, nem sempre o cenário financeiro é favorável ao uso de tais tecnologias, comprometendo a produtividade.

Respondente 2: Vários são os desafios enfrentados pelos pecuaristas de corte, no Brasil a falta de gestão, registro e controle de dados dificulta a tomada de decisão precisa. Desta maneira, ações corretivas para os maiores gargalos, através de ações públicas ou privadas, não são desenvolvidas. Além, desta dificuldade dentro da porteira, os tramites burocráticos principalmente no quesito exportação, limita o consumo da carne brasileira no exterior. Com relação a pecuária em nível mundial, vejo a pressão ambiental como o grande desafio a ser vencido pelo setor.

Respondente 3: A falta de informação sobre a origem dos produtos e as limitações na rastreabilidade estão entre as principais dificuldades enfrentadas pela pecuária de corte. Ainda, se poderia elencar a falta de um planejamento global de controle de zoonoses e de doenças como Encefalite Espongiforme Bovina (ESV) e a Febre Aftosa. A falta de padronização de acabamento de carcaça e dos cortes também é um problemas, pois cortes padronizados poderiam reduzir os custos operacionais das empresa, mas, como essa é uma questão essencialmente cultural, está entre as mais difíceis de ser equacionada. A nível nacional, os principais entraves são a baixa adoção de tecnologias básicas como suplementação mineral, manejo correto de pastagens e armazenamento de forragens, falhas decorrentes da descapitalização e do baixo nível técnico de uma grande parcela dos pecuaristas, este em parte, devido a deficiências na difusão de tecnologias. Ainda se pode citar as deficiências no modelo de rastreabilidade e a falta de um plano factível para o controle de enfermidades como Tuberculose, Brucelose, ESB e Febre Aftosa Por fim, embora extremamente eficientes em termos produtivos, as raças zebuínas ainda não apresentam o marmoreio e maciez de carne exigidos por mercados com maior poder econômico. 
Questão 2: Quais são os diferenciais da produção bovina de corte brasileira, comparada a outros grandes produtores como EUA, China e Argentina?

Respondente 1: O Brasil se diferencia dos países citados por inúmeros fatores, dentre eles a heterogeneidade do produto. Podemos encontrar no Brasil produtos semelhantes ao Argentino (tanto quanto às características organolépticas, quanto à produtividade), assim como NorteAmericano. Se por um lado isso pode ser visto de forma favorável por agregar valor aos produtos diferenciados (nichos de mercado), também refletem a falta de padronização do produto. Outro diferencial é o potencial de aumento na produtividade brasileira, apresentando um "delta" superior aos demais países citados.

Respondente 2: $O$ grande diferencial é o baixo custo de produção, devido a extensão territorial e elevado percentual de bovinos criados a pasto.

Respondente 3: $O$ Brasil dispõe de terras e água abundantes, permitindo a cadeia produtiva brasileira oferecer ao mercado um produto que se diferencia em sabor e modelo de produção. Contudo, para esse diferencial se configurar como vantagem competitiva e não apenas comparativa, é preciso "vender" aos consumidores as vantagens do consumo da carne do "boi verde", ou seja, do boi produzido em pastagens.

\section{Questão 3- Quais tecnologias estão sendo empregadas atualmente para a melhoria da eficiência produtiva?}

Respondente 1: As tecnologias empregadas em larga-escala que têm proporcionado incremento na eficiência produtiva são: a) uso de touros/sêmen geneticamente superiores quanto à características específicas; b) inseminação artificial em tempo fixo (IATF); c) métodos para diagnosticar prenhez mais precocemente; d) avanços na nutrição animal, especificamente uso de suplementos e aditivos alimentares visando manipulação da fermentação ruminal e eficiência metabólica, e) tecnologias de manejo das pastagens, cito diferimento das pastagens para uso no inverno.

Respondente 2: Existem uma gama grande de novas tecnológicas nas mais diversas áreas da produção como, nutrição, reprodução, sanidade, tecnologia de precisão, bem estar animal, etc. Porém, mais importante do que novas tecnologias é levar e implantar as tecnologias novas 
ao mesmo já existente. Fato este pela desconexão entre pesquisa e extensão, dificuldade financeira do produtor ou mesmo resistência a mudanças que existe no campo.

Respondente 3: Apesar da pouca eficiência na difusão de tecnologias na pecuária, o Brasil avança a passos largos em desenvolvimento de tecnologias ligadas a reprodução, melhoramento genético, nutrição e manejo de pastagens. Contudo, penso que o maior avanço tem sido no melhoramento genético. $O$ árduo trabalho de pesquisadores e produtores rurais nos últimos 60 anos, resultou em raças altamente produtivas e adaptadas a regiões de clima tropical. Atualmente o zebuíno brasileiro é mais produtivo que o indiano e rivaliza em pé de igualdade com as raças britânicas neste quesito. Em relação a qualidade da carne, é questão de tempo até termos uma linhagem de Nelore transmitindo características de maciez e marmoreio em padrões semelhantes as das raças Angus e Hereford.

\section{Questão 4- Quando se fala de sustentabilidade, em quais aspectos ela é aplicada de forma prática na pecuária bovina de corte?}

Respondente 1: Particularmente enxergo a palavra "sustentabilidade" sendo usada de forma abstrata, mas podemos associar com: a) sustentabilidade financeira, uma vez que a pecuária é uma atividade econômica, deve se auto-sustentar (balanço entre receitas e despesas, e fluxo de caixa); b) ambiental: a emissão de gases do efeito estufa pode ser inferior ao "sequestrado" para síntese de biomassa de forragem, e c) manutenção/atração do homem no campo, gerando emprego, renda e alimentos à população. Ainda podemos considerar sistemas que integram produção de madeira, e ou demais sistemas alternativos de produção.

Respondente 2: Vejo a sustentabilidade em projetos que preservam as áreas de reserva legal, tendo os gestores acompanhando a rentabilidade da atividade e que se preocupam com a qualidade e satisfação dos colaboradores. Nem só o ambiental, mas o econômico e o social também são fatores que devem ser avaliados com relação a sustentabilidade do projeto.

Respondente 3: Penso que o melhoramento genético é um dos principais elementos para uma pecuária sustentável. A redução de idade de abate de 36 ou 48 meses para 18 a 24 meses, assim como o aumento da taxa de natalidade. favorecem a otimização do alimento consumido e em função redução do tempo até o abate reduzem a quantidade de metano emitido em cerca de $30 \%$ a 50\%. O adequado manejo das forrageiras reduz a necessidade de avançar sobre áreas 
de mata para implantação de novas pastagens. Da mesma forma, o aproveitamento dos pastos naturais do Bioma Pampa permite produzir sem impactar negativamente o meio ambiente, pelo contrário, o correto manejo dos pastos nativos através do pastejo favorece a preservação desse bioma. O sistema integrado de produção agropecuária são também uma ferramenta reconhecida para a sustentabilidade, pois favorece a microbiologia do solo através do sinergismo das propriedades emergentes dessas atividades produtivas. Não obstante, em razão desse sinergismo, o emprego desse sistema reduz a quantidade de fertilizantes e defensivos químicos necessários para a produção de grãos, através da quebra do ciclo de plantas indesejáveis e pragas. Cabe ressaltar, que a pecuária de corte bem conduzida é uma fonte de renda que ajuda a fixar o produtor no campo e dessa forma, além de atender aos aspectos financeiros, contempla também os aspectos de cunho social, através da manutenção do seu modo de vida e cultural. Assim, no meu ponto de vista, a pecuária de corte tem condições de abarcar os três pilares da sustentabilidade, quais são o econômico, social e ambiental.

\section{Questão 5 - Quando se analisa o consumo de carne bovina no mundo, qual é a tendência vislumbrada por especialistas e quais variáveis implicam nisso?}

Respondente 1: Historicamente o aumento do consumo de proteína de origem animal é positivamente correlacionado com o aumento da renda da população. Ainda que o número pessoas optando pelo não consumo deste alimento ser crescente, acredito que o consumo per capita continuará seguindo padrões históricos em relação à renda da população, e o setor produtivo avançará quanto ao emprego de tecnologias conforme a demanda pelo produto.

Respondente 2: Existem uma tendência do consumidor selecionar cada vez mais os alimentos que ingerem. A carne acredito que seguirá no mesmo caminho, desta forma vejo que carne rastreada e de sistema sustentáveis podem tornar uma realidade não apenas na Europa e EUA. Tais tendências teria implicação econômica na produção, principalmente no quesito gestão, e no varejo.

Respondente 3: Nos últimos 20 anos quase 1 bilhão de pessoas no mundo saíram da condição de miserabilidade e com mais renda puderam consumir itens que antes não tinham acesso, como a carne bovina. Penso que a tendência tanto do consumo per capta como bruto tenda a crescer nos próximos 30 anos. Em termos de implicação econômica entendo que haverá uma expansão na produção e produtividade de países emergentes como China, Brasil e Índia (apesar de serem essencialmente vegetarianos). Outra território de expansão serão os países 
da África subsaariana, gerando emprego e renda para esse territórios e auxiliando na redução da miséria e da fome. Como efeito econômico colateral nos países em desenvolvimento poderá haver maior concentração de terra em regiões em expansão agrícola e a especialização da produção em pontos distintos das áreas de pecuária. Essa especialização seguirá o caminho já trilhado pelos suinos e aves, em que são poucos os produtores que desenvolvem os ciclos de cria, recria e engorda de forma combinada.

Questão 6-Após a apresentação dos 4 cenários apresentados, indique o cenário que considera (1) extrapolativo (que excede os limites), (2) exploratório (que necessita fundamentos aprofundados) e (3) normativo (que tem capacidade de ser concretizado).

Respondente 1: (1) extrapolativo - cenário 2 (2) exploratório - cenário 4 e (3) normativo cenário 3

Respondente 2: (1) extrapolativo - cenário 4 (2) exploratório - cenário 3 e (3) normativo cenário 2

Respondente 3: (1) extrapolativo - cenário 2 (2) exploratório - cenário 3 e (3) normativo cenário 4

\subsubsection{Conexão da validação dos cenários com o modelo da pesquisa}

Ao analisar as afirmações dos respondentes e os argumentos tratados até o momento nessa pesquisa, foi possível perceber que há um alto nível de conformidade com o modelo desenvolvido na pesquisa, relatado no subtítulo 10.4.

Entre as principais dificuldades da produção bovina de corte no Brasil e no Mundo estão o cenário financeiro desfavorável para o uso de tecnológicas que promovam a produtividade, mas em vista disso, algumas ações corretivas, com o envolvimento de políticas públicas e privadas poderiam ser executadas para a correção de gargalos e redução da pressão ambiental por condições sustentáveis de produção. Além disso, a baixa adoção e difusão de tecnologias básicas tornam baixa a produtividade e de certa forma, ineficiente.

Por outro lado, o Brasil têm se diferenciado de outros grandes produtores de carne bovina devido ao seu potencial de aumento na produtividade brasileira, baixo custo de produção e 
clima e terras com água abundante, permitindo a cadeia produtiva brasileira oferecer ao mercado um produto que se diferencia em sabor e modelo de produção. Porém, uma vez que essa superioridade produtiva existe, ela poderá ser mantida desde que as tecnologias mais avançadas sejam adotadas e implantadas a fim de que aprimorem as atuais técnicas de produção.

Ao se referir a tecnologia, nem sempre essa tem associação com a sustentabilidade, a qual é muitas vezes aplicada de forma abstrata ou é relacionada apenas á áreas de preservação, quando na verdade, poderia ser aplicada em todos os aspectos da cadeia produtiva e de consumo da pecuária bovina de corte, possibilitando que o sentido mais amplo do termo (pilares econômico, social e ambiental) sejam aplicados de forma plena.

De acordo com os especialistas respondentes a validação dos cenários, a tendência é de ocorra uma expansão na demanda de carne bovina, especialmente em países emergentes como China, Brasil e Índia e que o consumo per capita progrida conforme os padrões históricos do Pib per capita, ao passo que os avanços tecnológicos avançarão conforme a demanda de carne bovina.

Com respeito aos cenários desenvolvidos, as opiniões não são unânimes. Em sua maioria, o Cenário 2 foi considerado como algo extrapolativo. Isso acontece pois a opinião dos especialistas indica um futuro promissor à avanços tecnológicos na pecuária bovina de corte. Porém, identificam em sua maioria que o Cenários 3 e 4 estão entre o exploratório e normativo, com capacidade de ser concretizado, desde que hajam fundamentos aprofundados. 


\section{CONSIDERAÇÕES FINAIS}

O uso de recursos naturais (finitos e não renováveis) do planeta Terra de forma sustentável na produção e no consumo global de carne bovina constituem o tema orientador dessa pesquisa. Para que a pergunta de pesquisa e os objetivos propostos pudessem ser respondidos e identificados, foi realizada uma pesquisa exploratória qualitativa relacionada à produção de carne bovina (com o objetivo de identificar recursos naturais empregados na, consequências do uso e indicadores de sustentabilidade), juntamente com uma pesquisa descritiva qualitativa e quantitativa concernente as fases de produção, consumo global e variáveis influenciadoras nesse. Após as pesquisas, foi realizado o desenvolvimento de um modelo prospectivo de nível sustentável de produção e consumo pecuarista bovino, seguido pela fase de simulações e elaboração de cenários preditivos, os quais passaram pela validação de especialistas, conforme é contemplada na metodologia de WRIGHT, J. T. C.; SPERS (2006).

De uma maneira geral, podem-se citar as principais considerações em relação aos constructos dessa pesquisa:

1-Consumo de Recursos Naturais - foi possível perceber, especialmente pelo modelo criado a partir da metodologia Ecological Footprint que os recursos fundamentais e associados à evolução da produção de carne bovina (como ocupação de solo, energia, água, minérios e oxigênio) são, de fato, empregados na produção e no consumo de carne bovina e trazem consequências que podem comprometer o futuro das gerações. Porém, mesmo tendo ciência disso, foi identificado nas entrevistas com especialistas que a pecuária bovina de corte não tem a prática de realizar algum método de mensuração disso ou a preocupação em adoção de técnicas que objetivem a redução no consumo de recursos naturais, a menos que essas venham acompanhada de ganhos de eficiência produtiva.

2-Nível de Degradação Ambiental - pela tendência estimada na pesquisa, é possível notar que o nível de degradação tende a aumentar, caso não sejam realizadas mudanças nos processos e níveis de produção, adoção de novas tecnologias ou mudança de hábitos de consumo. O modelo desenvolvido prevê, por meio das simulações, um nível crescente de degradação, o qual é 
bastante reduzido mediante avanços tecnológicos que visem aumento de eficiência no uso de recursos naturais.

3-Processo de Renovação de Recursos Naturais - foram identificadas formas de mitigar e renovar os recursos naturais utilizados na produção de carne bovina: recuperação de biomassas degradadas, fertilidade do solo, rotação de cultura do solo e reaproveitamento/captação de recursos hídricos. Essas medidas foram contempladas no cenário que prevê a aplicação de tecnologia avançada ao processo produtivo de carne bovina. Segundo os especialistas entrevistados, esse processo pode ser aplicado de forma paralela, ao nível de degradação ambiental. Contudo ainda há a necessidade de conscientização de produtores e apoio governamental para que a aplicação de tecnologias avançadas seja possibilitado.

4-Nível de Produção Sustentável - com base na metodologia Ecological Footprint, o modelo desenvolvido na pesquisa apresentou um indicador de sustentabilidade, por meio de algumas simulações, as quais indicaram diferentes níveis de produção e consequências para a biocapacidade dos países analisados. O método indicou a necessidade de algumas mudanças na forma econômica e social de lidar com a produção e consumo de carne bovina, para que seja alcançado um nível sustentável.

5-Cenários de Consumo Sustentável - mediante a elaboração e análise de cenários construídos para a produção e consumo global de carne bovina, foi possível identificar diferentes ópticas, com diferentes implicações. Contudo, todos os cenários tinham em comum a busca pela sustentabilidade através da mitigação dos impactos causados pelo uso da biocapacidade de recursos naturais do planeta.

Embora haja uma subjetividade presente em qualquer investigação no campo das ciências sociais, é possível dizer, com base nas considerações feitas nessa pesquisa e literatura investigada (relacionada a recursos naturais e impactos ambientais, indicadores de sustentabilidade e cenários) que as investigações possam ser extrapoladas para outros setores, fazendo uso do modelo de produção e consumo sustentável de carne bovina, com as devidas adaptações. Isso torna-se aplicável pois a pesquisa foi estruturada por meio de uma metodologia científica, com etapas e procedimentos definidos. 
Para a seleção dos especialistas entrevistados, buscou-se pesquisadores com formação e aderência ao tema, além de alguns deles possuírem experiência profissional na área pesquisada. A partir do modelo, da teoria que o embasou e das demais teorias estudadas para a elaboração dessa pesquisa, foi desenvolvido um questionário estruturado para entrevistas. Na pesquisa e especialmente nas entrevistas, procurou-se identificar quais são os padrões observados para dificuldades e diferenciais na produção brasileira comparada a outros grandes produtores, tecnologias, aplicação de sustentabilidade, tendências de consumo global de carne bovina.

Em sequência a essa seção de Considerações Finais, são apresentados a pergunta de pesquisa, os objetivos propostos e as considerações finais dessa pesquisa.

Pergunta de Pesquisa: Considerando-se que alguns recursos naturais do planeta Terra são finitos e não renováveis, quais cenários plausíveis de produção e consumo global sustentável de carne bovina podem ser projetados para $2040 ?$

A pesquisa indicou 4 cenários plausíveis de produção e consumo, nos quais apenas 1 deles garante o equilíbrio e a sustentabilidade global no uso de recursos.

Quanto ao objetivo geral da pesquisa, que é :

A proposição de um modelo prospectivo com cenários globais para identificação de um padrão sustentável de produção e consumo de carne bovina pela população global para 2040, com base nos recursos naturais disponíveis e tendências sociais, econômicas e tecnológicas futuras.

A pesquisa, por meio do modelo prospectivo desenvolvido, indicou um horizonte de consequências decorrentes do atual processo produtivo e consumo de carne bovina global, acompanhado de tendências sociais de consumo, variáveis econômicas influenciadoras e tecnologias futuras e, ao mesmo tempo, indicou medidas e ações potenciais que possam modificar esse horizonte vindouro para um horizonte próspero no sentido sustentável natural do planeta. 
Quanto aos objetivos específicos, estes são:

1-Caracterização dos principais recursos naturais relacionados à produção de carne bovina;

Por meio das pesquisas exploratórias realizadas, foi possível identificar que os minerais, a água e solo são os principais recursos utilizados na produção de carne bovina, os quais nem sempre são regenerados e além disso produzem uma grande quantidade de gases nocivos ao meio ambiente.

2-Caracterização das variáveis fundamentais associadas à evolução da produção e consumo de carne bovina;

As pesquisas indicaram que a produção e o consumo de carne bovina tem sofrido evolução, especialmente devido ao aumento populacional e influência das oscilações do Pib per capita.

3-Identificação e análise de indicadores sociais, econômicos e de sustentabilidade, juntamente com suas implicações para a produção e o consumo de carne bovina;

Os indicadores sociais identificados na pesquisa estão relacionados à influência para o consumo, ocasionada pelo aumento populacional, pelo discurso midiático e pela evolução de renda. O indicador econômico analisado foi o Pib per capita, o qual indicou, até mesmo nas análises estatísticas da pesquisa, uma forte associação ao consumo. Entre os indicadores de sustentabilidade mais utilizados está o Ecological Footprint, que em seu histórico indica que o consumo de recursos naturais está muito acima de sua regeneração e com isso, estudos já indicavam a necessidade de ajustes em diferentes setores, inclusive na agricultura e pecuária.

4-Identificação de tendências tecnológicas que possam afetar, diretamente ou indiretamente, a utilização de recursos naturais para a produção de carne bovina;

Muitas são as tendências tecnológicas que podem ser aplicadas na produção de carne bovina. Algumas das tecnologias avançadas existentes para a produção bovina são: a aplicação da genética para aumento da produtividade e lucratividade dos rebanhos de corte, o manejo de pastagens com a iLPF e estratégias para eficiência reprodutiva bovina. 
5-Proposição de um modelo prospectivo que contemple cenários globais e identifique um padrão sustentável de produção e consumo de carne bovina, através da combinação do uso de recursos naturais, variáveis econômicas, tendências tecnológicas e padrões globais de consumo de alimentos.

O modelo desenvolvido na pesquisa indicou o atual status da produção e do consumo de carne bovina e em paralelo, suas consequências, acompanhado de tendências sociais de consumo, variáveis econômicas influenciadoras e tecnologias futuras. Além disso o modelo propõe medidas e ações potenciais que possam transformar esse cenário vindouro em um cenário diferenciado, de cunho sustentável global para o planeta e economicamente favorável.

\section{6- Identificação de possibilidades que os cenários do futuro proporcionam à tomadores de decisão vislumbrarem políticas públicas e estratégias tecnológicas e de mercado para os negócios.}

Os cenários elaborados nessa pesquisa indicaram diferentes possibilidades, as quais evidenciam diferentes saldos de Biocapacidade Global, que são resultado de níveis de eficiência no uso de recursos naturais pela pecuária bovina de corte. Alguns desses cenários indicaram a necessidade de aplicação de políticas públicas e estratégias tecnologias que visem a melhoria em produtividade com vistas a oportunidades de mercado e geração de negócios internacionais.

$\mathrm{Na}$ medida em que essa pesquisa avançava, foram surgindo questionamentos que sugerem novas pesquisas. Dentre eles, destacam-se:

- Qual é a percepção de pesquisadores estrangeiros acerca dos cenários elaborados? A resposta a essa pergunta poderá trazer grandes contribuições e novas ideias de tecnologias implementadas em diferentes países a fim de alcançar níveis de sustentabilidade produtiva.

- Qual é a proporção exata do crescimento do Pib per capita que equivale ao crescimento global do consumo de carne bovina? A resposta a essa questão pode consistir na resolução das equações polinomiais que se originaram nas regressões múltiplas de consumo com Pib per capita durante a análise de resultados. 
- Poderia ser o mesmo modelo replicado para outros tipos de pecuária? Não é possível afirmar que sim, mas as análises levam a crer que o modelo possui potencial de aplicação em diferentes pecuárias, sofrendo ajustes nas variáveis analisadas e na EF aplicada.

- Poderia a inflação ser incluída como variável econômica no modelo, além de uma análise se as projeções de consumo de carne bovina, juntamente com o Pib per capita, são alteradas? No modelo não foi contemplada essa variável, mas poderia ser incluída e não apenas nos países que atualmente são responsáveis pela maior parte do consumo de carne bovina, mas também pelo restante do mundo, para verificar o quanto essa variável está impactando ou impedindo que o consumo aumente.

- Quais ações poderiam ser tomadas na China, que mesmo no cenário sustentável global apresenta alto déficit no uso de Biocapacidade na Pecuária Bovina? A China, considerada como uma país emergente, apresenta uma destacada tendência de crescimento, porém de acordo com as simulações, apresenta um grande déficit de recursos, mesmo com avanços tecnológicos consideráveis. 


\section{REFERÊNCIAS}

ABESO. Mapa da Obesidade. http://www.obeso.org.br, 2015. Disponível em: < http://www.abeso.org.br/atitude-saudavel/mapa-obesidade >. Acesso em: 22 de agosto.

ABIEC. Brasil tenta recuperar mercado de carne bovina na África. 2012. Disponível em: < http://www.abiec.com.br/news_view.asp?id=\%7BAE8E13B0-82D6-41B4-8998-

D8EB5E9D7936\%7D $>$. Acesso em: 10 de janeiro

Balanço da Pecuária Brasileira. 2014

AGOSTINHO, F.; PEREIRA, L. Support area as an indicator of environmental load: Comparison between Embodied Energy, Ecological Footprint, and Emergy Accounting methods. Ecological Indicators, v. 24, p. 494-503, 2013.

AGROLINK. A América Latina é a segunda potência mundial em produção de proteína animal. 2015. Disponível em: < http://www.agrolink.com.br/noticias/a-america-latina-e-a-segundapotencia-mundial-em-producao-de-proteina-animal_224099.html $>$. Acesso em: 09 de janeiro.

AL-MULALI, U. et al. Investigating the environmental Kuznets curve (EKC) hypothesis by utilizing the ecological footprint as an indicator of environmental degradation. Ecological Indicators, v. 48, n. 0, p. 315-323, 1// 2015.

ALBUQUERQUE, L.; MEYER, K. Estimates of covariance functions for growth of Nelore cattle applying a parametric correlation structure to model within-animal correlations. Livestock Production Science, v. 93, n. 3, p. 213-222, 2005.

ALEXANDRATOS, N. et al. World Agriculture: Towards 2030/2050: Prospects for Food, Nutrition, Agriculture and Major Commodity Groups. Interim Report, Global Perspective Studies Unit. Food and Agriculture Organization of the United Nations, Rome (June), 2006.

ALEXANDRINO, E. et al. Características morfogênicas e estruturais na rebrotação da Brachiaria brizantha cv. Marandu submetida a três doses de nitrogênio. Revista Brasileira de Zootecnia, v. 33, n. 6, p. 1372-1379, 2004.

ALIGLERI, L.; ALIGLERI, L. A.; KRUGLIANSKAS, I. Gestão socioambiental: responsabilidade e sustentabilidade do negócio. Atlas, 2009. ISBN 8522455058.

ALVARENGA, R. A. F. D.; DA SILVA JÚNIOR, V. P.; SOARES, S. R. Comparison of the ecological footprint and a life cycle impact assessment method for a case study on Brazilian broiler feed production. Journal of Cleaner Production, v. 28, p. 25-32, 2012.

ALVES, S. O sistema que dá certo. Pecuária Brasil 2015.

ANDRADE, A. C. et al. Características morfogênicas e estruturais do Capimelefante'Napier'adubado e irrigado. Ciência e Agrotecnologia, v. 29, n. 1, p. 150-159, 2005. 
ANDRADE, R. P. Pasture seed production technology in Brazil. International Grassland Congress, 2001. p.129-132.

ANICS, A. N. D. I. D. C. S. Ásia deve aumentar consumo de carne bovina em $58 \%$ em oito anos 2014a. Disponível em: < http://www.anics.com.br/site/noticias/mostrar/264 >. Acesso em: 09 de janeiro.

. Países em desenvolvimento concentrarão consumo de carne 2014b. Disponível em: < http://www.anics.com.br/site/noticias/mostrar/266 >. Acesso em: 09 de janeiro.

BAGLIANI, M.; BRAVO, G.; DALMAZZONE, S. A consumption-based approach to environmental Kuznets curves using the ecological footprint indicator. Ecological Economics, v. 65, n. 3 , p. $650-661,2008$.

BALATSKY, A. V.; BALATSKY, G. I.; BORYSOV, S. S. Resource Demand Growth and Sustainability Due to Increased World Consumption. Sustainability, v. 7, n. 3, p. 3430-3440, 2015.

BALBINO, L. C. et al. Evolução tecnológica e arranjos produtivos de sistemas de integração lavoura-pecuária-floresta no Brasil. Pesquisa Agropecuária Brasileira, v. 46, p. 0-0, 2011.

BARBIER, E. B. Economics, Natural-Resource Scarcity and Development Conventional and Alternative Views. Earthscan, London.: Routledge 1989.

Endogenous growth and natural resource scarcity. Environmental and Resource Economics, v. 14, n. 1, p. 51-74, 1999.

BARBIER, E. B. et al. Paradise Lost?: the ecological economics of biodiversity. Beijer International Institute of Ecological Economics (Suiza). 1995. (0253-4746)

BARCELLOS, J. O. J.; SUÑE, Y. B. P.; SEMMELMANN, C. A bovinocultura de corte frente a agriculturização no sul do Brasil. Ciclo de atualização em medicina veterinária, v. 11, p. 13-30, 2004.

BARCELLOS, M. D. Beef lovers: um estudo cross-cultural sobre o comportamento de consumo de carne bovina. . 2007. Tese (Doutorado em Agronegócios)-Programa de PósGraduação em Agronegócios da Universidade Federal do Rio Grande do Sul, Porto Alegre.

BARLOW, M.; CLARKE, T. Ouro azul: como as grandes corporações estão se apoderando da água doce do nosso planeta. M. Books do Brasil Ed., 2003. ISBN 9788589384049.

BARNETT, H. J.; MORSE, C. Scarcity and Growth: The Economics of Natural Resource Availability, by Harold J. Barnett and Chandler Morse. Johns Hopkins Press, 1963.

BARONI, L. et al. Evaluating the environmental impact of various dietary patterns combined with different food production systems. Eur J Clin Nutr, v. 61, n. 2, p. 279-286, 10/11/online 2006. 
BARROS, A. L. M.; HAUSKNECHT, J. C. O. F. V. Mudanças tecnológicas elevam produtividade. Visão Agrícola - ESALQ-USP, v. No 3, 2005.

BAUMGÄRTNER, S. et al. Relative and absolute scarcity of nature. Assessing the roles of economics and ecology for biodiversity conservation. Ecological Economics, v. 59, n. 4, p. 487-498, 10/15/ 2006.

BAUMGÄRTNER, S. et al. Relating the philosophy and practice of ecological economics: The role of concepts, models, and case studies in inter- and transdisciplinary sustainability research. Ecological Economics, v. 67, n. 3, p. 384-393, 10/15/ 2008.

BEEF2LIVE. World Beef Exports: Ranking Of Countries. 2015a

World Beef Production: Ranking Of Countries. 2015b

BEEFPOINT. Índices de produtividade da pecuária de corte no Brasil. Parte 1/3. 2000. Disponível em: $<$ http://www.beefpoint.com.br/cadeia-produtiva/conjuntura-de-

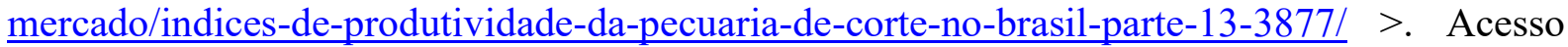
em: 18 de julho de 2016.

Alta demanda por carnes na África cria oportunidades. 2016a. Disponível em: < http://www.beefpoint.com.br/cadeia-produtiva/giro-do-boi/alta-demanda-por-carnes-naafrica-cria-oportunidades/ >. Acesso em: 10 de janeiro.

Indústria de carne bovina ajuda a estabelecer políticas sobre sustentabilidade. $2016 \mathrm{~b}$. Disponível em: < http://www.beefpoint.com.br/cadeia-produtiva/giro-do-boi/industria-decarne-bovina-ajuda-a-estabelecer-politicas-sobre-sustentabilidade/ $>$. Acesso em: 28 de dezembro.

BEEFWORLD. Custos de produção de carne bovina no Brasil é um dos mais baixos. 2014. Disponível em: < http://www.beefworld.com.br/noticia/custos-de-producao-de-carne-bovinano-brasil-e-um-dos-mais-baixos $>$. Acesso em: 14 de janeiro.

BELIK, W.; MALUF, R. S. Abastecimento e segurança alimentar: os limites da liberalização. UNICAMP, Instituto de Economia, 2000.

BIOLCHINI, J. C. D. A. et al. Scientific research ontology to support systematic review in software engineering. Adv. Eng. Inform., v. 21, n. 2, p. 133-151, 2007.

BITTENCOURT, M. V. L. Impactos da agricultura no meio-ambiente: Principais tendências e desafios (Parte 1). 2012. ISBN 2238-1988|escape\}.

BLAIR, D.; SOBAL, J. Luxus Consumption: Wasting Food Resources Through Overeating. Agriculture and Human Values, v. 23, n. 1, p. 63-74, 2006. 
BLIGNAUT, J.; ARONSON, J.; DE GROOT, R. Restoration of natural capital: A key strategy on the path to sustainability. Ecological Engineering, v. 65, n. 0, p. 54-61, 4// 2014.

BOCKSTAEL, N. et al. Ecological economic modeling and valuation of ecosystems. Ecological Economics, v. 14, n. 2, p. 143-159, 8// 1995.

BOFF, L. Sustentabilidade: o que é : o que não é. Vozes, 2012. ISBN 9788532642981.

BONTEMPO, M. T. Análise comparativa dos métodos de construção de cenários estratégicos no planejamento empresarial. 2000. (Mestrado). Controladoria e Contabilidade, Faculdade de Economia, Administração e Contabilidade da Universidade de São Paulo

BOROUSH, M. A.; THOMAS, C. W. Alternative scenarios for the defense industry after 1995. Planning Review, v. 20, n. 3, p. 24-29, 1992.

BORUCKE, M. et al. Accounting for demand and supply of the biosphere's regenerative capacity: The National Footprint Accounts' underlying methodology and framework. Ecological Indicators, v. 24, n. 0, p. 518-533, 1// 2013.

BOULDING, K. E. The economics of the coming spaceship earth. Environmental Quality Issues in a Growing Economy, 1966.

BOUMA, J.; BATJES, N. H.; GROOT, J. J. R. Exploring land quality effects on world food supply. Geoderma, v. 86, n. 1-2, p. 43-59, 10// 1998.

BOURDIEU, P.; MICELI, S. A economia das trocas simbólicas. Perspectiva São Paulo, 1974.

BRANDER, J. A. Viewpoint: Sustainability: Malthus revisited? Canadian Journal of Economics/Revue canadienne d'économique, v. 40, n. 1, p. 1-38, 2007.

BRASHARES, J. S. et al. Economic and geographic drivers of wildlife consumption in rural Africa. Proceedings of the National Academy of Sciences, v. 108, n. 34, p. 13931-13936, August 23, 20112011.

BRITO, F. V.; FRIES, L. A. Proposta de um método para avaliação genética de bovinos de corte. 1994.

BROWN, J.; ASH, A. Pastures for prosperity. Tropical Grasslands, v. 30, p. 47-57, 1996.

BROWN, J. H. et al. Macroecology meets macroeconomics: Resource scarcity and global sustainability. Ecological Engineering, v. 65, n. 0, p. 24-32, 4// 2014.

BROWN, L.; FLAVIN, C.; FRENCH, H. Estado do mundo 2000. Salvador: UMA Ed, 2000.

BRUE, S. L. História do Pensamento Econômico. São Paulo: Cengage Learning, 2005.

BRUINSMA, J. The resource outlook to 2050. Expert meeting on how to feed the world in, 2009. p.1-33. 
BRUNDTLAN, C. Comissão Mundial sobre Meio Ambiente e Desenvolvimento: o nosso futuro comum. Universidade de Oxford. . Nova Iorque. 1987

BRUYNE, P. D.; HERMAN, J.; SCHOUTHEETE, M. D. Dinâmica da pesquisa em ciências sociais: os pólos da prática metodológica. In: (Ed.). Dinâmica da pesquisa em ciências sociais: os pólos da prática metodológica, 1982.

CALDER, W.; CLUGSTON, R. M. Progress toward sustainability in higher education. Environmental Law Reporter News and Analysis, v. 33, n. 1, p. 10003-10022, 2003.

CÂMARA DOS DEPUTADOS. Lei no 4.771, de 15 de setembro de 1965. 2012. Disponível em: < http://www2.camara.leg.br/legin/fed/lei/1960-1969/lei-4771-15-setembro-1965-

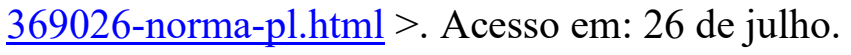

CARVALHO, E. O.; ROCHA, E. F. D. Consumo alimentar de população adulta residente em área rural da cidade de Ibatiba (ES, Brasil). Ciência \& Saúde Coletiva, v. 16, p. 179-185, 2011.

CARVALHO, P. D. F. A estrutura da pastagem e o comportamento ingestivo de ruminantes em pastejo. Simpósio sobre avaliação de pastagens com animais, v. 1, p. 25-52, 1997.

CARVALHO, T. B. D.; ZEN, S. D. Cadeia de pecuária de corte: perspectivas de produção e consumo no Brasil $48^{\circ}$ Congresso Sober - Sociedade Brasileira de Economia, Administração e Sociologia Rural. Campo Grande - MS - Brasil 2009.

CARVAlHO, T. B. D.; ZEN, S. D.; TAVARES, É. C. N. COMPARAÇÃO DE CUSTO DE PRODUÇÃO NA ATIVIDADE DE PECUÁRIA DE ENGORDA NOS PRINCIPAIS PAÍSES PRODUTORES DE CARNE BOVINA. $47^{\circ}$ SOBER - Sociedade Brasileira de Economia, Administração e Sociologia Rural. Porto Alegre/RS - Brasil 2009.

CASTAGNARA, D. et al. Valor nutricional e características estruturais de gramíneas tropicais sob adubação nitrogenada. Archivos de zootecnia, v. 60, n. 232, p. 931-942, 2011.

CAVALCANTI, C.; FURTADO, A. Desenvolvimento e natureza: estudos para uma sociedade sustentável. Cortez; Fundação Joaquim Nabuco, 1995. ISBN 8524905727.

CEPEA/ESALQ. PIB Agro CEPEA-USP/CNA 1995 a 2015. 2015

CERUTTI, A. K. et al. Application of Ecological Footprint Analysis on nectarine production: methodological issues and results from a case study in Italy. Journal of Cleaner Production, v. 18, n. 8, p. 771-776, 2010.

CERUTTI, A. K. et al. Evaluation of the sustainability of swine manure fertilization in orchard through Ecological Footprint Analysis: results from a case study in Italy. Journal of Cleaner Production, v. 19, n. 4, p. 318-324, 2011.

CERUTTI, A. K. et al. Multifunctional Ecological Footprint Analysis for assessing ecoefficiency: a case study of fruit production systems in Northern Italy. Journal of Cleaner Production, v. 40, p. 108-117, 2013. 
CHANG, I. S. et al. Ecological compensation for natural resource utilisation in China. Journal of Environmental Planning and Management, v. 57, n. 2, p. 273-296, 2014/02/01 2013.

CHAPAGAIN, A. K. Globalisation of water: Opportunities and threats of virtual water trade. TU Delft, Delft University of Technology, 2006. ISBN 0415409160.

CHAPAGAIN, A. K.; HOEKSTRA, A. Y. Water footprints of nations. 2004.

CHAPAGAIN, A. K.; ORR, S. An improved water footprint methodology linking global consumption to local water resources: a case of Spanish tomatoes. J Environ Manage, v. 90, n. 2, p. 1219-28, Feb 2009.

CLEAVER, H. M., JR. The Contradictions of the Green Revolution. The American Economic Review, v. 62, n. 1/2, p. 177-186, 1972.

CNA, C. D. A. E. P. D. B. Pecuária de Corte ainda resiste a crises. Ativos Pecuária de Corte, v. Ano 8 - Edição 31 - Julho de 2016, 2016. Disponível em: < file:///Users/reginaornellas/Documents/ativos_corte_31.pdf $>$.

COOK, D. J.; MULROW, C. D.; HAYNES, R. B. Systematic reviews: synthesis of best evidence for clinical decisions. Annals of internal medicine, v. 126, n. 5, p. 376-380, 1997.

COOPERS, P. W. The World in 2050. Will the shift in global economic power continue. London: Price Waterhouse Coopers. Accessed July, v. 27, p. 2015, 2015.

CORNELIUS, P.; VAN DE PUTTE, A.; ROMANI, M. Three decades of scenario planning in shell. California management review, v. 48, n. 1, p. 92-109, 2005.

CORRÊA, A. N. S. Gado de corte: 500 perguntas e respostas. Brasília: EMBRAPA, 1996.

CORSI, M. Potencial das pastagens para producao de leite. Peixoto, AM; Moura, JC DE; Faria, VP DE. Bovinocultura leiteira: Fundamentos da exploracao racional., 1985.

COSTA, L. A. V.; IGNÁCIO, R. P. Relações de Consumo x Meio Ambiente: Em busca do Desenvolvimento Sustentável. Âmbito Jurídico, v. XIV, 2011.

CRUZ, P.; BOVAL, M. Effect of nitrogen on some morphogenetic traits of temperate and tropical perennial forage grasses. Lemaire, G.; Hodgson, J, p. 151-168, 2000.

CSR/UFMG, C. D. S. R. E. E. D. V. D. U. F. D. M. G. Cenários para a Pecuária de Corte Amazônica. 2015. Disponível em: < http://csr.ufmg.br/pecuaria/ >. Acesso em: 28 de dezembro.

DAHMUS, J. B. Can Efficiency Improvements Reduce Resource Consumption? Journal of Industrial Ecology, v. 18, n. 6, p. 883-897, 2014.

DALEY, C. A. et al. A review of fatty acid profiles and antioxidant content in grass-fed and grain-fed beef. Nutrition journal, v. 9, n. 1, p. 1, 2010. 
DALY, H. E. Steady-state economics: with new essays. Island Press, 1991. ISBN 1597268720.

DARWIN, C.; GARCIA, L. D. S. L. A expressão das emoções no homem e nos animais COMPANHIA DE BOLSO, 2009. ISBN 9788535913989.

DAY, J. W. et al. Sustainability and place: How emerging mega-trends of the 21 st century will affect humans and nature at the landscape level. Ecological Engineering, v. 65, n. 0, p. 33-48, $4 / / 2014$.

DE CHARDIN, P. T. Fenômeno Humano, O. Cultrix, 2005. ISBN 9788531601682.

DE HAAN, C. et al. Livestock \& the environment: Finding a balance. European Commission Directorate-General for Development, Development Policy Sustainable Development and Natural Resources Rome,, Italy, 1997.

DE VRIES, F. W. T. P.; VAN KEULEN, H.; RABBINGE, R. Natural resources and limits of food production in 2040. In: BOUMA, J.;KUYVENHOVEN, A., et al (Ed.). Eco-regional approaches for sustainable land use and food production: Springer Netherlands, v.4, 1995. cap. 5, p.65-87. (Systems Approaches for Sustainable Agricultural Development). ISBN 97894-010-4058-7.

DE WIT, J. et al. Criteria for sustainable livestock production: a proposal for implementation. Agriculture, ecosystems \& environment, v. 53, n. 3, p. 219-229, 1995.

DEBLITZ, C. Beef and Sheep Report: understanding agriculture worldwide. 2012

DELGADO, C. L. et al. Livestock to 2020: The next food revolution. Intl Food Policy Res Inst, 1999. ISBN 0896296326.

DIAS-FILHO, M. B. Os desafios da produção animal em pastagens na fronteira agrícola brasileira. Revista Brasileira de Zootecnia, v. 40, p. 243-252, 2011.

. Diagnóstico das pastagens no Brasil. Embrapa Amazônia Oriental-Documentos (INFOTECA-E), 2014.

DIETZ, S.; ADGER, W. N. Economic growth, biodiversity loss and conservation effort. Journal of Environmental Management, v. 68, n. 1, p. 23-35, 5/1/ 2003.

DIETZ, T.; ROSA, E. A.; YORK, R. Driving the human ecological footprint. Frontiers in Ecology and the Environment, v. 5, n. 1, p. 13-18, 2007.

DRECHSLER, M. et al. Differences and similarities between ecological and economic models for biodiversity conservation. Ecological Economics, v. 62, n. 2, p. 232-241, 4/20/ 2007.

DUBÉ, L.; PARÉ, G. Rigor in information systems positivist case research: current practices, trends, and recommendations. MIS quarterly, p. 597-636, 2003. 
EDWARDS, P. J.; ABIVARDI, C. The value of biodiversity: Where ecology and economy blend. Biological Conservation, v. 83, n. 3, p. 239-246, 3// 1998.

EHRLICH, P. R.; EHRLICH, A. H. Can a collapse of global civilization be avoided? Proc Biol Sci, v. 280, n. 1754, p. 20122845, Mar 72013.

EHRLICH, P. R.; EHRLICH, A. H.; HOLDREN, J. P. Human Ecology: Problems and Solutions. W. H. Freeman, 1973. ISBN 9780716705956.

EISENHARDT, K. M. Building theories from case study research. Academy of management review, v. 14, n. 4, p. 532-550, 1989.

ELKINGTON, J. Sustentabilidade - Canibais com Garfo e Faca. São Paulo: M.Books, 2012. ISBN 9788576801238.

ESCOBAR, J. C. et al. Biofuels: Environment, technology and food security. Renewable and Sustainable Energy Reviews, v. 13, n. 6-7, p. 1275-1287, 8// 2009.

FADEL, J. G. Quantitative analyses of selected plant by-product feedstuffs, a global perspective. Animal Feed Science and Technology, v. 79, n. 4, p. 255-268, 6/30/ 1999.

FAO. FAO Statistical Yearbook 2013: World Food and Agriculture. 2013

. FAOSTAT: Food and Agriculture Organization of the United Nations 2014a.

. The State of Food and Agriculture: Innovation in family farming. Rome. 2014b

. Food Loss and Food Waste. http://www.fao.org, Food and Agriculture Organization of the United Nations, 2015. Disponível em: < http://www.fao.org/food-loss-and-foodwaste/en/ >. Acesso em: 25 de julho de 2015.

. Segurança alimentar e nutricional na América Latina e no Caribe. 2016. Disponível em: $<$ http://www.fao.org/americas/perspectivas/seguridad-alimentaria/pt/ > . Acesso em: $09 \mathrm{de}$ janeiro.

FAO; IFAD; WFP. The State of Food Insecurity in the World 2014. Food and Agriculture Organization of the United Nations. Rome. 2014

FAO; IIASA. Global Agro-Ecological Zones. 2000. Disponível em: < http://www.fao.org/nr/gaez/en// >. Acesso em: 29 de dezembro.

FEARNSIDE, P. M. Soybean cultivation as a threat to the environment in Brazil. Environmental Conservation, v. 28, n. 01, p. 23-38, 2001.

FERNANDEZ, F. A. D. et al. How Sustainable Is The Use of Natural Resources in Brazil? Natureza \& Conservacao, v. 10, n. 1, p. 77-82, Jul 2012. 
FOLHA, J. F. D. S. P. Escândalo de carne de cavalo na Europa afeta consumo. São Paulo, 2013. Disponível em: $<$ http://www1.folha.uol.com.br/mercado/2013/02/1233515-escandalode-carne-de-cavalo-na-europa-afeta-consumo.shtml $>$. Acesso em: 09 de janeiro.

FOUNDATION, H. B. L. Meat Atlas: facts and figures about the animals we eat. Berlin Germany. 2014

FRANÇA, F. C. O. et al. Mudanças dos hábitos alimentares provocados pela industrialização e o impacto sobre a saúde do brasileiro. $1^{\circ}$ Seminário Alimentação e Cultura na Bahia, 2012. Bahia - Brasil.

FREITAS, K. R. et al. Avaliação da composição químico-bromatológica do capim mombaça (Panicum maximum Jacq.) submetido a diferentes doses de nitrogênio. Bioscience Journal, v. 23, n. 3, 2007.

FRICKE, W.; MCDONALD, A. J. S.; MATTSON-DJOS, L. Why do leaves and leaf cells of N-limited barley elongate at reduced rates? Planta, v. 202, n. 4, p. 522-530, 1997.

FRIES, L.; SCHENKEL, F. Estimation and prediction under a selection model. REUNIÃO ANUAL DA SOCIEDADE BRASILEIRA DE ZOOTECNIA, v. 30, p. 1-22, 1993.

GALE, R. P.; CORDRAY, S. M. Making Sense of Sustainability: Nine Answers to 'What Should Be Sustained?'1. Rural Sociology, v. 59, n. 2, p. 311-332, 1994.

GALLI, A. et al. Ecological Footprint: Implications for biodiversity. Biological Conservation, v. 173, p. 121-132, 2014.

GALlOWAY, J. N. et al. International Trade in Meat: The Tip of the Pork Chop. AMBIO: A Journal of the Human Environment, v. 36, n. 8, p. 622-629, 2007/12/01 2007.

GARDI, C. et al. Land take and food security: Assessment of land take on the agricultural production in Europe. Journal of Environmental Planning and Management, n. ahead-ofprint, p. 1-15, 2014.

GARVIN, D. A.; LEVESQUE, L. C. A Note on Scenario Planning1. Harvard Business School, 17 de Novembro 2005.

GASTAL, F.; NELSON, C. J. Nitrogen use within the growing leaf blade of tall fescue. Plant physiology, v. 105, n. 1, p. 191-197, 1994.

GEORGESCU-ROEGEN, N. The entropy law and the economic process in retrospect. Eastern Economic Journal, p. 3-25, 1986.

GERBENS-LEENES, P.; NONHEBEL, S.; IVENS, W. A method to determine land requirements relating to food consumption patterns. Agriculture, ecosystems \& environment, v. 90, n. 1, p. 47-58, 2002.

GIAMPIETRO, M.; SALTELLI, A. Footprints to nowhere. Ecological Indicators, v. 46, p. 610-621, 2014. 
GIL, A. C. Métodos e técnicas de pesquisa social. In: (Ed.). Métodos e técnicas de pesquisa social: Atlas, 2010.

GIMENES, F. M. D. A. et al. Ganho de peso e produtividade animal em capim $\square$ marandu sob pastejo rotativo e adubação nitrogenada. Pesq. agropec. bras., Brasília, v. 46, n. 7, p. 751-759, 2011.

GLIESSMAN, S. R. Agroecology: researching the ecological basis for sustainable agriculture. In: (Ed.). Agroecology: Springer, 1990. p.3-10.

\section{GLOBAL FOOTPRINT NETWORK. National Footprint Accounts 2016.}

GLOBO G1. Alta procura salva mercado de alimentos saudáveis da crise. 2016. Disponível em: $\quad<\quad$ http://g1.globo.com/economia/noticia/2016/05/alta-procura-salva-mercado-dealimentos-saudaveis-da-crise.html $>$. Acesso em: 26 de julho.

GODET, M. Manual de prospectiva estratégica: da antecipação a acção. Lisboa: Publicações Dom Quixote, 1993.

GOELLNER, C. O uso da Água e a Agricultura In: (Ed.). Uso da água na agricultura: UPF, 2004. p.8.

GOODLAND, R. Environmental sustainability in agriculture: diet matters. Ecological Economics, v. 23, n. 3, p. 189-200, 12/5/ 1997.

GOSS, J.; HOLCOMB, R. B.; WARD, C. E. Factors Influencing Consumer Decisions Related to" Natural" Beef In The Southern Plains. Journal of Food Distribution Research, v. 33, n. 1, p. 73-84, 2002.

GRANNIS, J.; HOOKER, N. H.; THILMANY, D. Consumer preferences for specific attributes in natural beef products. Proceedings of Western Agricultural Economics Association Annual Meeting, 2000.

GRIGG, D. Income, Industrialization and Food Consumption Tijdschrift voor economische en sociale geografie, v. 85, n. 1, p. 3-14, 1994.

GUSTAVSSON, J. et al. Global food losses and food waste. Food and Agriculture Organization of the United Nations, Rom, 2011.

GUTZLER, C. et al. Agricultural land use changes - a scenario-based sustainability impact assessment for Brandenburg, Germany. Ecological Indicators, v. 48, n. 0, p. 505-517, 1// 2015.

HABERL, H. et al. Quantifying and mapping the human appropriation of net primary production in earth's terrestrial ecosystems. Proceedings of the National Academy of Sciences, v. 104, n. 31, p. 12942-12947, 2007.

HAIR JR, J. F. et al. Fundamentos de métodos de pesquisa em administração: Porto Alegre: Bookman 2005. 
HAKKERT, R. Um mundo de 7 bilhões: perspectivas da população. TULLOCH, J. http://sustentabilidade.allianz.com.br/?1638/mundo-7-bilhoes-perspectivas-da-populacao:

Sustentabilidade Allianz 2011.

HARVARD. Food Pyramids and Plates: What Should You Really Eat? , http://www.hsph.harvard.edu/, $2015 . \quad$ Disponível em: < http://www.hsph.harvard.edu/nutritionsource/pyramid-full-story/ > Acesso em: 28 de julho de 2015.

HEIKKINEN, S.; MAULA, J. Finnish Food Consumption, 1860-1993. Kuluttajatutkimuskeskus, 1996. ISBN 9789516980037.

HERENDEEN, R. A. Ecological footprint is a vivid indicator of indirect effects. Ecological Economics, v. 32, n. 3, p. 357-358, 3// 2000.

HERRING, H. Does energy efficiency save energy? The debate and its consequences. Applied Energy, v. 63, n. 3, p. 209-226, 7// 1999.

. Energy efficiency - a critical view. Energy, v. 31, n. 1, p. 10-20, 1// 2006.

HERRING, H.; SORRELL, S.; ELLIOTT, D. Energy efficiency and sustainable consumption: the rebound effect. Palgrave Macmillan Basingstoke, 2009. ISBN 0230525342.

HOCKLEY, N.; JONES, J. P. G.; GIBBONS, J. M. Technological Progress Must Accelerate to Reduce Global Footprint Overshoot: Peer-Reviewed Letter. Frontiers in Ecology and the Environment, v. 6, n. 3, p. 122-123, 2008.

HODGSON, J. Grazing management. Science into practice. Longman Group UK Ltd., 1990. ISBN 0582450101.

HOEKSTRA, A. Y.; MEKONNEN, M. M. The water footprint of humanity. Proceedings of the national academy of sciences, v. 109, n. 9, p. 3232-3237, 2012.

HOUAISS, A.; VILLAR, M. D. S. Grande dicionário Houaiss da língua portuguesa. HOUAISS, I. Rio de Janeiro: Objetiva 2001.

HUSS, W. R.; HONTON, E. J. Scenario planning-what style should you use? Long range planning, v. 20, n. 4, p. 21-29, 1987.

HUYSMAN, S. et al. Toward a systematized framework for resource efficiency indicators. Resources, Conservation and Recycling, v. 95, n. 0, p. 68-76, 2// 2015.

JAKOB, M.; EDENHOFER, O. Green growth, degrowth, and the commons. Oxford Review of Economic Policy, v. 30, n. 3, p. 447-468, 2014.

JONES-WALTERS, L.; MULDER, I. Valuing nature: The economics of biodiversity. Journal for Nature Conservation, v. 17, n. 4, p. 245-247, 12// 2009. 
JORGENSON, A. K.; BURNS, T. J. The political-economic causes of change in the ecological footprints of nations, 1991-2001: A quantitative investigation. Social Science Research, v. 36, n. 2 , p. 834-853, 6// 2007.

KAIMOWITZ, D. et al. Hamburger connection fuels Amazon destruction. Bangor, Indonesia: Center for International Forest Research, 2004.

KAIMOWITZ, D.; SMITH, J. Soybean technology and the loss of natural vegetation in Brazil and Bolivia. Wallingford, Oxon, UK: CABI Publishing, 2001. 195-211

KATES, R. W. What kind of a science is sustainability science? Proc Natl Acad Sci U S A, v. 108, n. 49, p. 19449-50, Dec 62011.

KELLNER, D.; BENEDETTI, I. C. A cultura da mídia: estudos culturais: identidade e política entre o moderno eo pós-moderno. EDUSC, 2001. ISBN 8574600733.

KISHTAINY, N. et al. O livro da Economia. São Paulo: Editora Globo, 2013.

KISSINGER, M.; FIX, J.; REES, W. E. Wood and non-wood pulp production: Comparative ecological footprinting on the Canadian prairies. Ecological Economics, v. 62, n. 3-4, p. 552558, 2007.

KITZES, J.; WACKERNAGEL, M. Answers to common questions in Ecological Footprint accounting. Ecological Indicators, v. 9, n. 4, p. 812-817, 2009.

KITZES, J. et al. Shrink and share: humanity's present and future Ecological Footprint. 2008. 467-475

KLEIBOER, M. Simulation methodology for crisis management support. Journal of Contingencies and Crisis Management, v. 5, n. 4, p. 198-206, 1997.

KLEIN, C.; DUTROW, B. Manual de Ciência dos Minerais. Bookman, 2009. ISBN 9788540700857.

KNEESE, A. V. Economics and the Environment. Canadá: Penguim Books, 1977.

KOWALSKI, M. F.; SWILLING, M. Decoupling Natural Resource Use and Environmental Impacts from Economic Growth. 2011

LACKEY, R. T. Seven pillars of ecosystem management. Landscape and urban planning, v. 40, n. 1, p. 21-30, 1998.

LAZARUS, E. et al. Working Guidebook to the National Footprint Accounts. Global Footprint Network. Oakland. 2014

LEACH, A. M. et al. A nitrogen footprint model to help consumers understand their role in nitrogen losses to the environment. Environmental Development, v. 1, n. 1, p. 40-66, 1// 2012.

LÉLÉ, S.; NORGAARD, R. B. Sustainability and the Scientist's Burden 
La sostenibilidad y la carga que soportan los científicos. Conservation Biology, v. 10, n. 2, p. 354-365, 1996.

LENKA, N. K.; LENKA, S.; BISWAS, A. K. Scientific endeavours for natural resource management in India. Current Science, v. 108, n. 1, p. 39-44, Jan 2015.

LEVY, Y.; ELLIS, T. J. A systems approach to conduct an effective literature review in support of information systems research. Informing Science: International Journal of an Emerging Transdiscipline, v. 9, n. 1, p. 181-212, 2006.

LOPES, K. R. F. Avicultura: da pré-história à produção industrial. Mossoró: Katia Regina Freire Lopes, 2010. ISBN 9781458307583.

LOPES, P. et al. Avaliação de métodos iterativos de resolução de equações de modelo misto. R. Soc. Bras. Zootec, v. 24, n. 3, p. 461-472, 1995.

LORENZ, K. Civilizacao e pecado: os oito erros capitais do homem. Artenova, 1974.

M. BAGLIANI, F. F.; PROCOPIO, S. The analysis of the environmental sustainability of the economic sectors of the Piedmont Region (Italy). In: TIEZZI, E. (Ed.). Ecosystems and Sustainable Development IV. Spain: University of Siena, Italy, C.A. Brebbia, Wessex Institute of Technology, UK and J-L. USO, Universitat Jaume I, Spain, v.1, 2003. p.613-622.

MARCIAL, E. C. Cenários prospectivos: como construir um futuro melhor. Editora FGV, 2015. ISBN 8522509239.

MARCONI, M. D. A.; LAKATOS, E. M. Fundamentos da metodologia científica. In: (Ed.). Fundamentos da metodologia científica: Altas, 2010.

MARTINE, G. O lugar do espaço na equação população/meio ambiente. Revista Brasileira de Estudos de População, v. 24, n. 2, p. 181-190, 2007.

MARTINS, E. et al. Desenvolvimento de um sistema para simulação de população de coelhos. Revista Brasileira de Zootecnia, v. 26, n. 2, p. 272-282, 1997.

MARTUSCELLO, J. A. et al. Características morfogênicas e estruturais de capim-massai submetido a adubação nitrogenada e desfolhação. Revista brasileira de Zootecnia, v. 35, n. 3 , p. 665-671, 2006.

MAY, P. H. Economia do Meio Ambiente, 2a Edição. Elsevier, 2010. ISBN 9788535266535.

MAZZANTI, A.; LEMAIRE, G.; GASTAL, F. The effect of nitrogen fertilization upon the herbage production of tall fescue swards continuously grazed with sheep. 1. Herbage growth dynamics. Grass and forage Science, v. 49, n. 2, p. 111-120, 1994.

MCMICHAEL, A. J. et al. Food, livestock production, energy, climate change, and health. The Lancet, v. 370, n. 9594, p. 1253-1263, // 2007. 
MEADOWS, D.; RANDERS, J.; MEADOWS, D. Limits to Growth: The 30-Year Update. Chelsea Green Publishing, 2004. ISBN 9781603581554.

MEADOWS, D. H. et al. The limits to growth. New York, v. 102, 1972.

MEKONNEN, M.; HOEKSTRA, A. The green, blue and grey water footprint of farm animals and animal products. 2010.

MEKONNEN, M. M.; HOEKSTRA, A. Y. National water footprint accounts: the green, blue and grey water footprint of production and consumption. 2011.

MESQUITA, E. E.; NERES, M. A. Morfogênese e composição bromatológica de cultivares de" Panicum maximum" em função da adubação nitrogenada. Revista Brasileira de Saúde e Produção Animal, v. 9, n. 2, 2008.

MILES, M. B.; HUBERMAN, A. M.; SALDANA, J. Qualitative data analysis: A methods sourcebook. SAGE Publications, Incorporated, 2013. ISBN 1452257876.

MONSANTO. Um breve histórico da Agricultura. http://www.monsanto.com, 2015. Disponível em: < http://www.monsanto.com/global/br/melhorar-a-agricultura/pages/umbreve-historico-da-agricultura.aspx $>$. Acesso em: 19 de julho de 2015.

MONTOYA, M.; YOUNG, K. R. Sustainability of natural resource use for an Amazonian indigenous group. Regional Environmental Change, v. 13, n. 6, p. 1273-1286, Dec 2013.

MORILHAS, L. J.; SCATENA, L. S.; MACEDO, L. O. B. A Cadeia da carne bovina no Brasil e as mudanças climáticas. In: MARCOVITCH, J. O. (Ed.). Para mudar o futuro: Mitigação de gases de efeito estufa: A experiência setorial e regional no Brasil. . São Paulo, v.v., 2009. p.p. 12-30.

MORILHAS, L. J.; WECHSLER, A. M. G.; KRUGLIANSKAS, I. O meio ambiente e o desenvolvimento. Revista Gerenciais. 6: 109-117 p. 2007.

MORSE, S.; VOGIATZAKIS, I. Resource Use and Deprivation: Geographical Analysis of the Ecological Footprint and Townsend Index for England. Sustainability, v. 6, n. 8, p. 4749-4771, 2014.

MÓZNER, Z. V. Sustainability and consumption structure: environmental impacts of food consumption clusters. A case study for Hungary. International Journal of Consumer Studies, v. 38, n. 5, p. 529-539, 2014.

MULAJ, F.; JACK, W. Evaluating the efficacy of mass media and social marketing campaigns in changing consumer financial behavior. 2012.

NASCIMENTO, M. Fertilizantes e sustentabilidade: o potássio na agricultura brasileira, fontes e rotas alternativas. CETEM/MCT, 2004. ISBN 8572272038.

NAYLOR, R. et al. Losing the Links Between Livestock and Land. Science, v. 310, n. 5754, p. 1621-1622, December 9, 20052005. 
NEKOLA, J. C. et al. The Malthusian-Darwinian dynamic and the trajectory of civilization. Trends in Ecology \& Evolution, v. 28, n. 3, p. 127-130, 3// 2013.

NEWTON, J. L.; FREYFOGLE, E. T. Sustainability: a Dissent. Conservation Biology, v. 19, n. 1, p. 23-32, 2005.

NOSS, R. F. Sustainability and Wilderness. Conservation Biology, v. 5, n. 1, p. 120-122, 1991.

NUERNBERG, K. et al. Effect of a grass-based and a concentrate feeding system on meat quality characteristics and fatty acid composition of longissimus muscle in different cattle breeds. Livestock Production Science, v. 94, n. 1, p. 137-147, 2005.

NUNES, H. M. B. et al. DIFERENÇAS ENTRE OS HÁBITOS ALIMENTARES ASSOCIADOS AO EXCESSO DE PESO DE CRIANÇAS E ADOLESCENTES DA ZONA RURAL E URBANA DO MUNICÍPIO DE SANTA CRUZ DO SUL-RS. Cinergis, v. 15, n. $1,2014$.

ODEGARD, I. Y. R. The Future of Food? Scenarios and the Effects on Resource Use in Agriculture. 2011. 173 (Master of Science in Industrial Ecology ). Institute of Environmental Sciences, Leiden University and Delft University of Technology

ODEGARD, I. Y. R.; VAN DER VOET, E. The future of food - Scenarios and the effect on natural resource use in agriculture in 2050. Ecological Economics, v. 97, n. 0, p. 51-59, 1// 2014.

OGINO, A. et al. Evaluating environmental impacts of the Japanese beef cow-calf system by the life cycle assessment method. Animal Science Journal, v. 78, n. 4, p. 424-432, 2007.

OJEDE, A.; MUGERA, A.; SEO, D. Macroeconomic Policy Reforms and Productivity Growth in African Agriculture Contemporary Economic Policy, v. 31, n. 4, p. 814-830, Oct 2013.

OLIVEIRA, R. L. et al. Nutrição e manejo de bovinos de corte na fase de cria. Revista Brasileira de Saúde e Produção Animal, v. 7, n. 1, 2006.

ONU. World Population Prospects: The 2002 Revision: Highlights. United Nations. 2003

ONUBR. Pecuária sustentável deve se tornar norma na América Latina e Caribe, diz FAO. 2016. Disponível em: < https://nacoesunidas.org/pecuaria-sustentavel-deve-se-tornar-normana-america-latina-e-caribe-diz-fao/ >. Acesso em: 10 de janeiro.

OPERA MUNDI, U. Símbolo do vegetarianismo, Índia vê consumo de carne aumentar $70 \%$ na última década. $2015 . \quad$ Disponível em: < http://operamundi.uol.com.br/conteudo/samuel/39237/simbolo+do+vegetarianismo+india+ve + consumo + de + carne + aumentar $+70+$ na + ultima + decada.shtml $>$. Acesso em: 09 de janeiro. 
ÖZLER, Ș. İ.; OBACH, B. K. Capitalism, State Economic Policy and Ecological Footprint: An International Comparative Analysis. Global Environmental Politics, v. 9, n. 1, p. 79-108, 2009.

PACIULLO, D. S. C.; GOMIDE, J. A.; RIBEIRO, K. G. Adubação nitrogenada do capimelefante cv. Mott. 1. Rendimento forrageiro e características morfofisiológicas ao atingir $80 \mathrm{e}$ $120 \mathrm{~cm}$ de altura. Revista Brasileira de Zootecnia, v. 27, n. 6, p. 1069-1075, 1998.

PARENTE, E. G. V.; PARENTE, J. More than Tecnology: The Knowability Customer to Sustainability. Ieee Latin America Transactions, v. 11, n. 2, p. 852-856, Mar 2013.

PARIS, W. et al. Produção de novilhas de corte em pastagem de Coastcross- 1 consorciada com Arachis pintoi com e sem adubação nitrogenada. Revista Brasileira de Zootecnia, v. 38, n. 1, p. 122-129, 2009.

PEREIRA, L. E. T. Morfogênese e estrutura do dossel de pastos de capim-marandu submetidos à lotação contínua e ritmos morfogênicos contrastantes. 2009. Escola Superior de Agricultura "Luiz de Queiroz

PEREIRA, L. E. T. et al. Sward structure of marandu palisadegrass subjected to continuous stocking and nitrogen-induced rhythms of growth. Scientia Agricola, v. 67, n. 5, p. 531-539, 2010 .

PIMENTEL, D. et al. Water resources: agriculture, the environment, and society. BioScience, p. 97-106, 1997.

PIMENTEL, D.; MARCIA H. PIMENTEL, M. S. Food, Energy, and Society, Third Edition. CRC Press, 2007. ISBN 9781420046687.

PINTO, Á. V. O conceito de tecnologia. 2005.

PORTER, M. E. Competitive Advantage: creating and sustaining superior performance. . Nova Iorque: The Free Press, 1998. ISBN 9788570015587.

PRETTY, J. et al. Policy challenges and priorities for internalizing the externalities of modern agriculture. Journal of environmental planning and management, v. 44, n. 2, p. 263-283, 2001.

PROCHASKA, F. J.; SCHRIMPER, R. A. Opportunity cost of time and other socioeconomic effects on away-from-home food consumption. American Journal of Agricultural Economics, v. 55, n. 4 Part 1, p. 595-603, 1973.

PULSELLI, F. M. et al. Integrating methods for the environmental sustainability: The SPInEco Project in the Province of Siena (Italy). Journal of Environmental Management, v. 86, n. 2, p. 332-341, 1// 2008.

QUIRINO, T. R.; IRIAS, L. J. M.; WRIGHT, J. T. C. Impacto agroambiental: perspectivas, problemas e prioridades. Embrapa Environment, 1999. ISBN 8521201737. 
REBELLO, F. D. F. P.; REBELLO, S. F. D. F. P. Qualidade de vida e a novas tendências do mercado de alimentos. Acta Tecnológica, v. 8, n. 1, p. 71-77, 2013.

REDCLIFT, M. R. Sustainability: Sustainable development. Routledge, 2005. ISBN 9780415340366.

REDMAN, B. J. The Impact of Women's Time Allocation on Expenditure for Meals Away from Home and Prepared Foods. American Journal of Agricultural Economics, v. 62, n. 2, p. 234-237, 1980.

REES, W. Revisiting carrying capacity: Area-based indicators of sustainability. Population and Environment, v. 17, n. 3, p. 195-215, 1996/01/01 1996.

REES, W.; WACKERNAGEL, M. Urban ecological footprints: Why cities cannot be sustainable - And why they are a key to sustainability. Environmental Impact Assessment Review, v. 16, n. 4-6, p. 223-248, 7// 1996.

REES, W. E. Ecological footprints and appropriated carrying capacity: what urban economics leaves out. Environment and urbanization, v. 4, n. 2, p. 121-130, 1992.

2001.

Concept of Ecological Footprint. Encyclopedia of biodiversity, v. 2, p. 229-244,

REILLY, J. M. Green growth and the efficient use of natural resources. Energy Economics, v. 34, Supplement 1, n. 0, p. S85-S93, 11// 2012.

RIBEIRO, K. G.; PEREIRA, O. G. Valor nutritivo do capim-tifton 85 sob doses de nitrogênio e idades de rebrotação. Veterinária e Zootecnia, v. 17, n. 4, p. 560-567, 2010.

RURAL CENTRO. Produção de carne bovina no Brasil: analista recomenda gestão de risco. 2012. Disponível em: < http://ruralcentro.uol.com.br/noticias/producao-de-carne-bovina-nobrasil-analista-recomenda-gestao-de-risco-56134 - y=1369 >. Acesso em: 14 de janeiro.

SACHS, I.; VIEIRA, P. F.; WEBER, J. Desenvolvimento sustentável, bio-industrialização descentralizada e novas configurações rural-urbanas: os casos da Índia e do Brasil. Gestão de Recursos Naturais Renováveis e Desenvolvimento-novos desafios para a pesquisa ambiental, v. 3, 2002.

SAHU, N. C.; NAYAK, B. Niche diversification in environmental/ecological economics. Ecological Economics, v. 11, n. 1, p. 9-19, 1994.

SALAS MARTINS, I. et al. Hábitos alimentares aterogênicos de grupos populacionais em área metropolitana da região sudeste do Brasil. Revista de Saúde Pública, v. 28, p. 349-356, 1994.

SANDERS, R. The Pareto principle: its use and abuse. Journal of Services Marketing, v. 1, n. 2, p. 37-40, 1987.

SANTOS, S. et al. Princípios básicos para a produção sustentável de bovinos de corte no Pantanal. Embrapa Pantanal-Documentos (INFOTECA-E), 2003. 
SARAVIA-CORTEZ, A. M. et al. Assessing environmental sustainability of particleboard production process by ecological footprint. Journal of Cleaner Production, v. 52, p. 301-308, 2013.

SBA, S. B. D. A. Confinadores podem aumentar produção em 2\%, diz estudo da Assocon. 2016. Disponível em: $<$ http://www.sba1.com/noticias/pecuaria-de-corte/70702/confinadorespodem-aumentar-producao-em-2-diz-estudo-da-assocon - .WGOT5WQrIb0 >. Acesso em: 28 de dezembro.

SCARE, R. F.; ANTOLINI, L. S.; MIRANDOLA, F. P. Análise do Processo Decisório de Compra de Inseminação Artificial por Pecuaristas de Gado de Corte. REA-Revista Eletrônica de Administração, v. 13, n. 2, p. 233-246, 2014.

SCHAEFER, F. et al. Ecological Footprint and Biocapacity: The world's ability to regenerate resources and absorb waste in a limited time period. Office for Official Publications of the European Communities: Luxembourg, 2006.

SCHLESINGER, W. H.; BERNHARDT, E. S. Chapter 6 - The Biosphere: Biogeochemical Cycling on Land. In: BERNHARDT, W. H. S. S. (Ed.). Biogeochemistry (Third Edition). Boston: Academic Press, 2013. p.173-231. ISBN 978-0-12-385874-0.

SCHLINDWEIN, M. M.; KASSOUF, A. L. Análise da influência de alguns fatores socioeconômicos e demográficos no consumo domiciliar de carnes no Brasil. Revista de Economia e Sociologia Rural, v. 44, n. 3, p. 549-572, 2006.

. Mudanças no padrão de consumo de alimentos tempo-intensivos e de alimentos poupadores de tempo, por região do Brasil. Gasto e consumo das famílias brasileiras contemporâneas. Brasília: IPEA, p. 423-62, 2007.

SCHOEMAKER, P. J. How to link strategic vision to core capabilities. Sloan Management Review, v. 34, n. 1, p. 67, 1992.

. Scenario planning: a tool for strategic thinking. Sloan management review, v. 36, n.

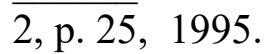

SCHWARTZ, P. A arte da visão de longo prazo: planejando o futuro em um mundo de incertezas. São Paulo: Best Seller, 2000.

SCOONES, I. Sustainability. Development in Practice, v. 17, n. 4-5, p. 589-596, 2007.

SEKARAN, U. Research methods for business: A skill building approach. John Wiley \& Sons, 2006. ISBN 8126509287.

SHAO, L.; WU, Z.; CHEN, G. Q. Exergy based ecological footprint accounting for China. Ecological Modelling, v. 252, p. 83-96, 2013.

SHEPHERD, R. A. The Development of American Agriculture: A Historical Analysis by Willard W. Cochrane. Indiana Magazine of History, 1981. 
SICHIERI, R.; CASTRO, J. F. G.; MOURA, A. S. Fatores associados ao padrão de consumo alimentar da população brasileira urbana Factors associated with dietary patterns in the urban Brazilian population. Cad. Saúde Pública, v. 19, n. Sup 1, p. S47-S53, 2003.

SINGER, P. I. Dinamica populacional e desenvolvimento o papel do crescimento populacional no desenvolvimento economico. Hucitec, 1988. ISBN 9788527100663.

SISLEGIS, S. D. L. A. F. Instrução Normativa $\mathrm{n}^{0}$ 007, de 17 de maio de 1999. 1999. Disponível em: $\quad<\quad$ http://extranet.agricultura.gov.br/sislegis-

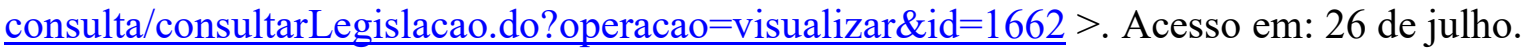

SITARZ, D. Agenda 21: The Earth Summit Strategy to Save Our Planet. EarthPress, 1993. ISBN 9780935755114.

SKINNER, B. J. Recursos minerais da Terra. Editôra Edgard Blücher, 1996.

SMIL, V. Energy at the crossroads: global perspectives and uncertainties. MIT press, 2005. ISBN 0262693240.

SMITH, G. et al. Residues of antibiotics, hormones and pesticides in conventional, natural and organic beef. Journal of Muscle Foods, v. 8, n. 2, p. 157-172, 1997.

SMULDERS, S.; TOMAN, M.; WITHAGEN, C. Growth theory and green growth. In: (Ed.). OxCarre Research Paper: University of Oxford, v.135, 2014.

STEFFEN, W. et al. The Anthropocene: conceptual and historical perspectives. Philosophical Transactions of the Royal Society of London A: Mathematical, Physical and Engineering Sciences, v. 369, n. 1938, p. 842-867, 2011.

STEFFEN, W. et al. Planetary boundaries: Guiding human development on a changing planet. Science, v. 347, n. 6223, February 13, 20152015.

STEINFELD, H. et al. Livestock's Long Shadow: environmental issues and options. Food and Agriculture Organization of the United Nations Roma, p.390. 2006

STERN, N. The economics of climate change: the Stern review. cambridge University press, 2007. ISBN 0521700809.

STERN, P. C.; YOUNG, O. R.; DRUCKMAN, D. Mudanças e agressões ao meio ambiente. Makron Books, 1993. ISBN 9788534600668.

STIGLITZ, J. Growth with exhaustible natural resources: efficient and optimal growth paths. The review of economic studies, p. 123-137, 1974.

SUBAK, S. Methane embodied in the international trade of commodities: Implications for global emissions. Global Environmental Change, v. 5, n. 5, p. 433-446, 12// 1995. 
SUTCLIFFE, M.; HOOPER, P.; HOWELL, R. Can eco-footprinting analysis be used successfully to encourage more sustainable behaviour at the household level? Sustainable Development, v. 16, n. 1, p. 1-16, 2008.

SUTTON, M. A. et al. Our Nutrient World: The challenge to produce more food and energy with less pollution. . Centre for Ecology and Hydrology. 2013

TAIZ, L.; ZEIGER, E. Fisiologia vegetal. In: (Ed.). Fisiologia vegetal: Artmed, 2009.

TEGTMEIER, E. M.; DUFFY, M. D. External costs of agricultural production in the United States. International Journal of agricultural sustainability, v. 2, n. 1, p. 1-20, 2004.

TILMAN, D. et al. Agricultural sustainability and intensive production practices. Nature, v. 418, n. 6898, p. 671-677, 08/08/print 2002.

TILMAN, D.; CLARK, M. Global diets link environmental sustainability and human health. Nature, v. 515, n. 7528, p. 518-522, 11/27/print 2014.

TILMAN, D. et al. Forecasting Agriculturally Driven Global Environmental Change. Science, v. 292, n. 5515, p. 281-284, April 13, 20012001.

TORRES JUNIOR, R. et al. Avaliação de metodologias de precisão de valor genético por meio de simulação. Revista Brasileira de Zootecnia, v. 26, p. 1142-1146, 1997.

TOYAMA, N. K.; MARTIN, N. B.; TACHIZAWA, E. H. A pecuária bovina de corte no Estado de São Paulo. Instituto de Economia Agricola, 1978.

UNDERWOOD, D. A.; KING, P. G. On the ideological foundations of environmental policy. Ecological Economics, v. 1, n. 4, p. 315-334, 1989.

UNESCO-WWAP. Fatos e dados - Relatório Mundial das Nações Unidas sobre o Desenvolvimento dos Recursos Hídricos 4. Organização das Nações Unidas para a Educação, a Ciência e a Cultura (UNESCO) e World Water Assessment Programme (WWAP). 2012

VAN BELLEN, H. M. Indicadores de sustentabilidade: uma análise comparativa. FGV Editora, 2005. ISBN 8522505063.

VAN DEN BERGH, J. C. J. M.; GRAZI, F. Ecological Footprint Policy? Land Use as an Environmental Indicator. Journal of Industrial Ecology, v. 18, n. 1, p. 10-19, 2014.

VANHAM, D.; MEKONNEN, M. M.; HOEKSTRA, A. Y. The water footprint of the EU for different diets. Ecological Indicators, v. 32, n. 0, p. 1-8, 9// 2013.

VECCHIA, C. L.; MAJEM, L. S. Evaluating trends in global dietary patterns. The Lancet Global Health, v. 3, n. 3, p. e114-e115, 2015.

VICENTE, P. O uso de simulação como metodologia de pesquisa em ciências sociais. Cadernos Ebape. BR, v. 3, n. 1, p. 01-09, 2005. 
VINNARI, M.; TAPIO, P. Future images of meat consumption in 2030. Futures, v. 41, n. 5, p. $269-278,6 / / 2009$.

WACKERNAGEL, M. et al. Ecological footprint time series of Austria, the Philippines, and South Korea for 1961-1999: comparing the conventional approach to an 'actual land area' approach. Land Use Policy, v. 21, n. 3, p. 261-269, 2004.

WACKERNAGEL, M.; YOUNT, J. D. The Ecological Footprint: an Indicator of Progress Toward Regional Sustainability. Environmental Monitoring and Assessment, v. 51, n. 1-2, p. 511-529, 1998/06/01 1998.

WANG, Y.; WANG, L.; SHAO, H. Ecological Footprint Analysis Applied to a CoalConsumption County in China. Clean - Soil, Air, Water, v. 42, n. 7, p. 1004-1013, 2014.

WEBER, M. H.; BENTZ, I. M. G.; HOHLFELDT, A. C. Tensões e objetos: da pesquisa em comunição. Sulina, 2002. ISBN 8520503063.

WFN, W. F. N. Water footprints of crops and derived crop products (1996-2005): Water Footprint Statistics 2005.

WHO. World Health Statistics 2014. WHO Press. 2014

WILLERS, B. Sustainable Development: A New World Deception. Conservation Biology, v. 8, n. 4, p. 1146-1148, 1994.

WOODRUFF, R. B.; GARDIAL, S. Know your customer: New approaches to understanding customer value and satisfaction. Wiley, 1996. ISBN 1557865531.

WORLD BANK. Agricultural methane emissions (\% of total). Washington, DC.: World Bank Open Data 2014a.

Open Data 2014b.

Agricultural nitrous oxide emissions (\% of total). Washington, DC.: World Bank Arable land (hectares per person). Washington, D.C: World Bank Open Data 2014c.

. Fertilizer consumption (kilograms per hectare of arable land). Washington, DC.: World Bank Open Data 2014d.

GDP per capita. Washington, DC.: World Bank Open Data 2014e.

. Life expectancy at birth. Washington, DC.: World Bank Open Data $2014 \mathrm{f}$.

. Rural Population. Washington, D.C.: World Bank Open Data 2014g.

Total Population. Washington, D.C: World Bank Open Data 2014h.

Urban Population. Washington, D.C.: World Bank Open Data 2014i. 
WRIGHT, J. Contribuição à técnica de análise e estruturação de modelos (ISM) para o planejamento em grupo: uma abordagem de inferência lógica. 1991. 204 (Tese (Doutorado em Administração de Empresas)). Faculdade de Economia, Administração e Contabilidade, Universidade de São Paulo, São Paulo.

WRIGHT, J. T. C.; SPERS, R. G. O país no futuro: aspectos metodológicos e cenários. Estudos Avançados, v. 20, n. 56, p. 13-28, 2006.

WTO, W. T. O. World Trade Report 2010 - Trade in Natural Resources. World Trade Organization, 2010. ISBN 1813-8136.

WWF, I. WWF Living Forests Report. Gland, Switzerland. 2011

. Living Planet Report. 2014

em:

. O que é desenvolvimento sustentável?, http://www.wwf.org.br, 2015. Disponível

http://www.wwf.org.br/natureza brasileira/questoes ambientais/desenvolvimento sustentavel I >. Acesso em: 23 de julho de 2015.

YORK, R. The Challenges of Measuring Environmental Sustainability: Comment on "Political and Social Foundations for Environmental Sustainability". Political Research Quarterly, v. 62, n. 1, p. 205-208, 2009.

ZALASIEWICZ, J. et al. Are we now living in the Anthropocene. GSA Today, v. 18, n. 2, p. 4, // 2008.

ZIEHL, A.; THILMANY, D. D.; UMBERGER, W. A cluster analysis of natural beef product consumers by shopping behavior, importance of production attributes, and demographics. Journal of Food Distribution Research, v. 36, n. 1, p. 209-217, 2005. 


\section{APÊNDICE A - TEXTO DO E-MAIL ENVIADO AOS RESPONDENTES}

\section{ESPECIALISTAS}

Assunto: Pesquisa de Doutorado FEA USP — Pecuária Bovina de Corte

Prezados Senhores,

Meu nome é Regina Ornellas e sou estudante de doutorado em Administração na Faculdade de Economia e Administração da Universidade de São Paulo (FEA-USP).

Estou enviando este e-mail para solicitar a sua colaboração na pesquisa que estou realizando para a elaboração da minha tese.

O objetivo principal da pesquisa é identificar, a partir de cenários pré-definidos e do uso de recursos naturais (finitos e não renováveis) do planeta Terra, um padrão sustentável de produção e de consumo global de carne bovina.

Os referidos cenários são:

- Cenário 1: Cenário Atual (dados de referencia 2011)

- Cenário 2: Cenário 2040 com Tecnologia Atual

- Cenário 3: Cenário 2040 com Avanço Tecnológico Moderado

- Cenário 4: Cenário 2040 com Avanço Tecnológico em busca da Sustentabilidade

Caso seja possível entrevistar outros pesquisadores relacionados às áreas de: pesquisa e desenvolvimento, pecuária, produção e/ou meio ambiente, por favor, avisem-me. Coloco-me a disposição para ir até a sede da instituição em qualquer dia ou horário, receber algum representante da instituição na FEA USP ou realizar a entrevista por outro meio de comunicação - se assim for mais conveniente (e-mail, telefone, skype).

O roteiro de entrevista é bastante sintético, levando poucos minutos para ser aplicado e tem por finalidade verificar as principais dificuldades na produção de carne bovina, bem como 
diferenciais brasileiros, tecnologias e tendências para os próximos 15 anos, bem como validar a aplicabilidade dos cenários elaborados.

Os dados, depois de identificados, serão analisados com a máxima confidencialidade que uma pesquisa possui, para uso exclusivamente acadêmico (portanto, sem fins comerciais).

Assim, gostaria de contar com a sua colaboração sendo participante de minha pesquisa, pois, as suas informações serão fundamentais para o resultado do meu estudo. Meu e-mail é reginaornellas@usp.br

Muito obrigada! Regina Ornellas — Pesquisadora. 
APÊNDICE B - SIMULAÇÃO 1

\begin{tabular}{|c|c|c|}
\hline 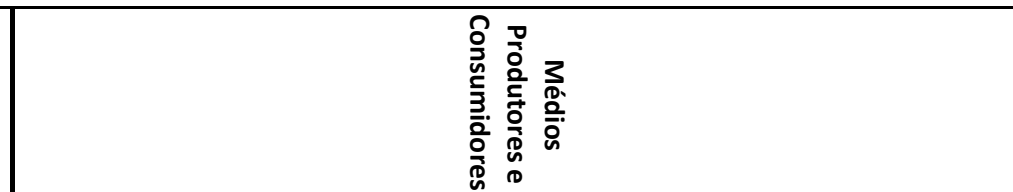 & 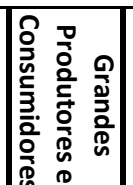 & \\
\hline 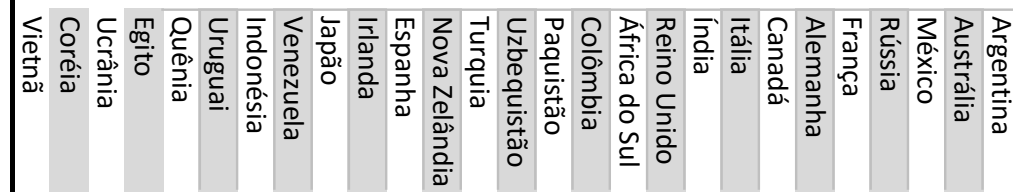 & 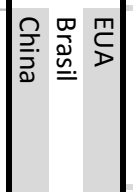 & $\frac{7}{\tilde{n}}$ \\
\hline 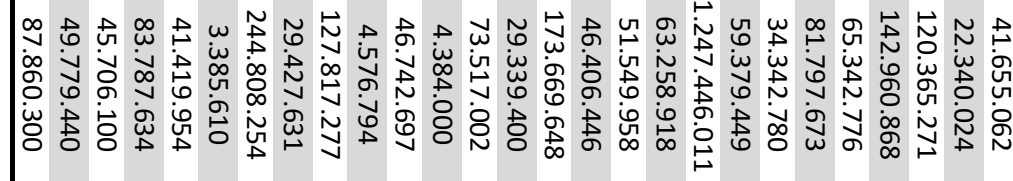 & 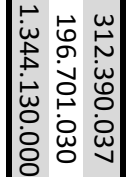 & 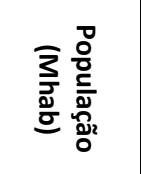 \\
\hline 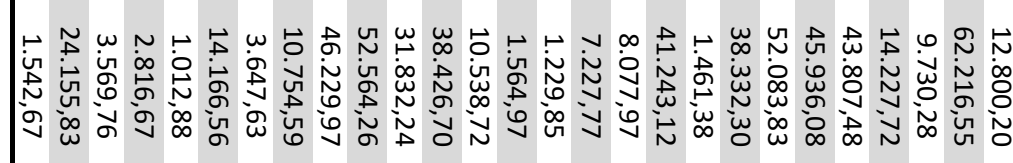 & 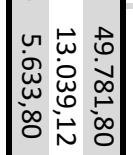 & $\underset{\frac{7}{5}}{\frac{7}{5}}$ \\
\hline 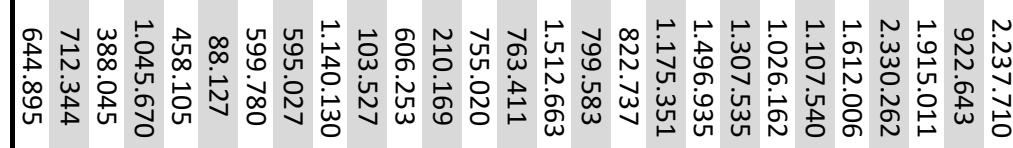 & 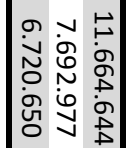 & 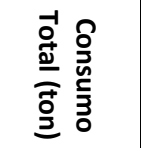 \\
\hline 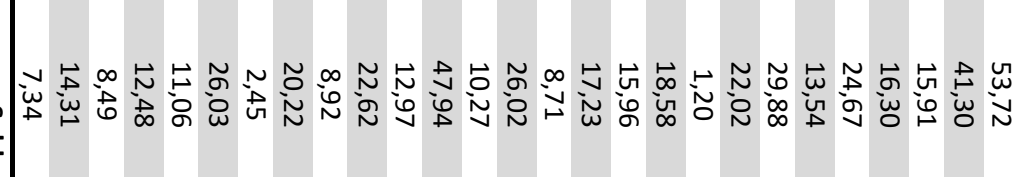 & 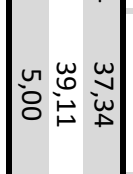 & 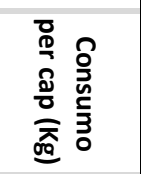 \\
\hline 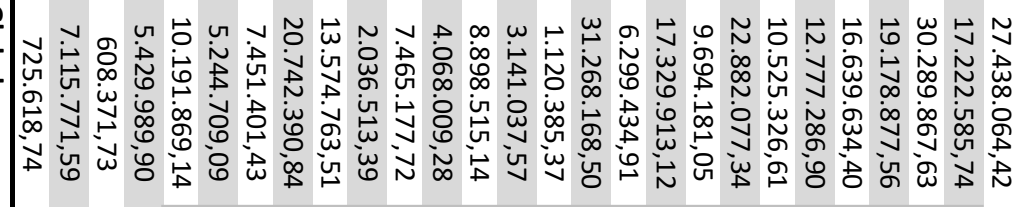 & 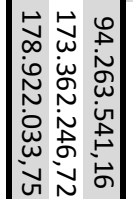 & 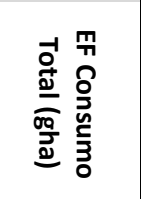 \\
\hline 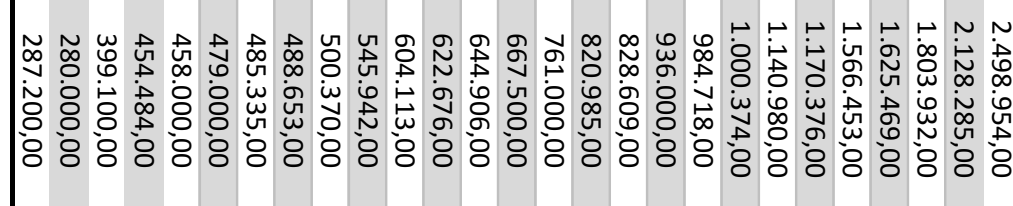 & 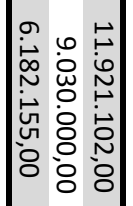 & 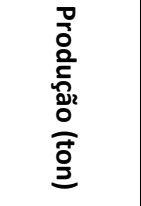 \\
\hline 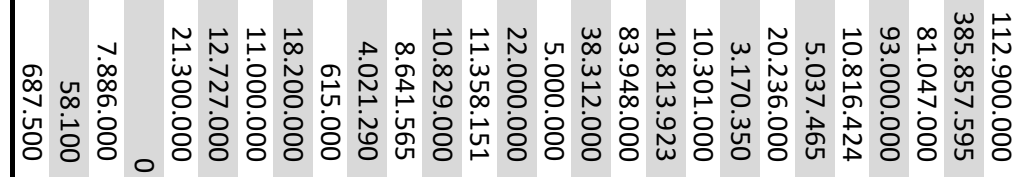 & 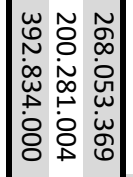 & 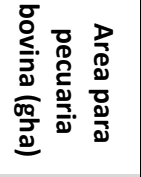 \\
\hline 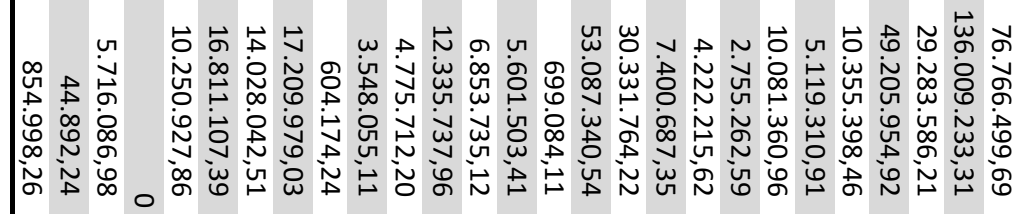 & 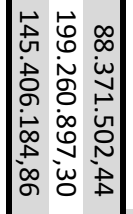 & 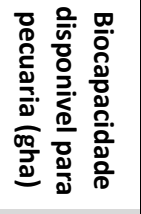 \\
\hline 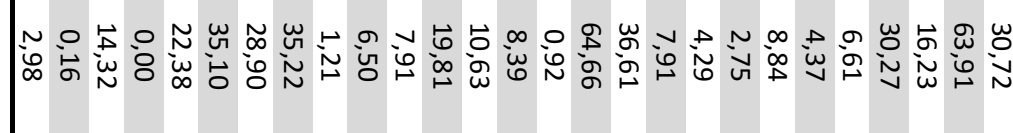 & 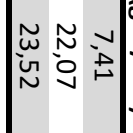 & 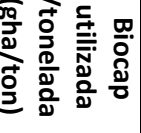 \\
\hline 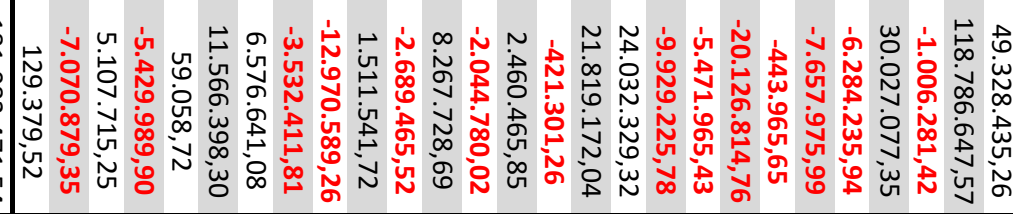 & 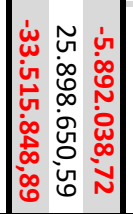 & 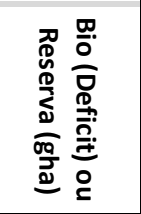 \\
\hline
\end{tabular}





\section{APÊNDICE C - SIMULAÇ̃̃O 2}

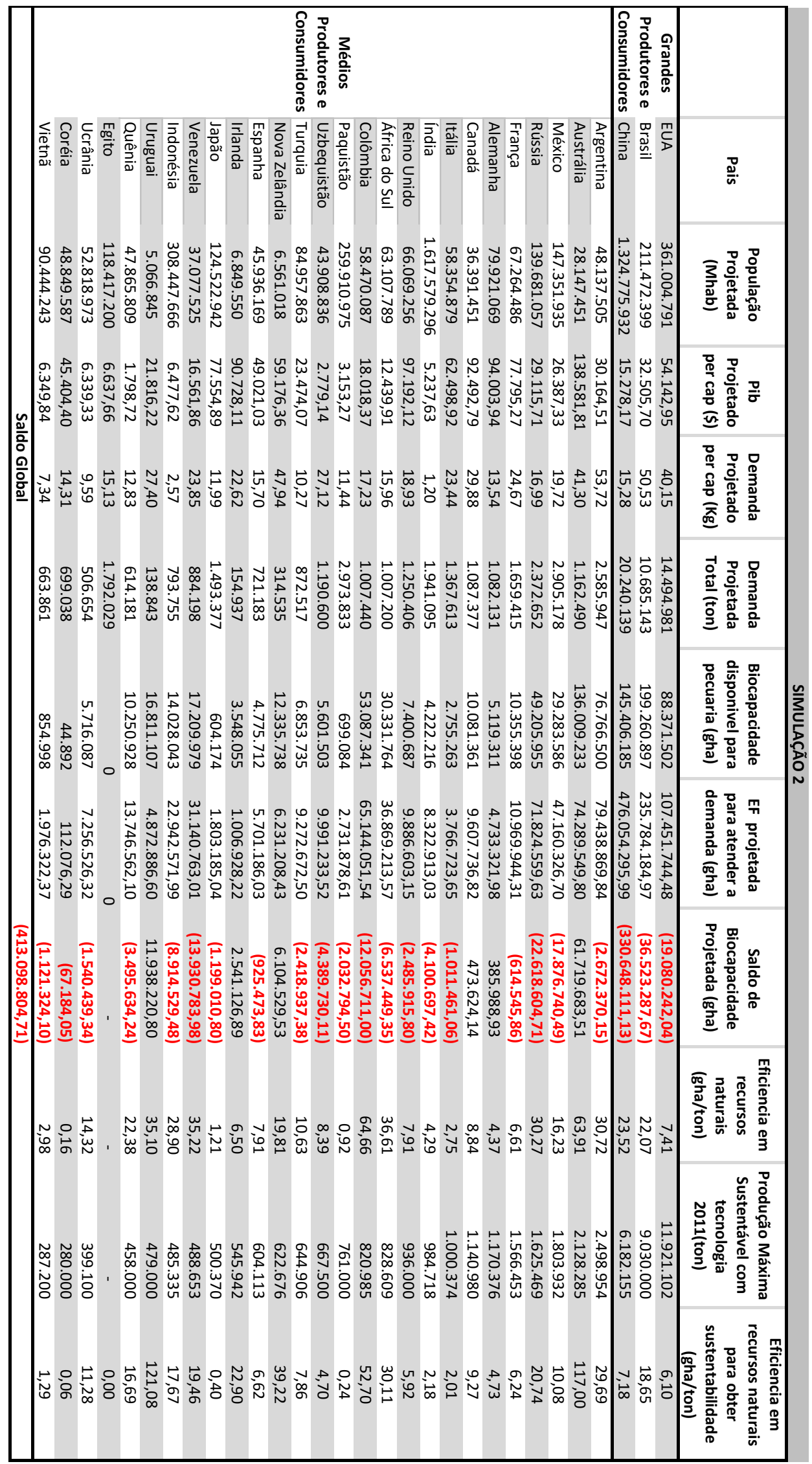


APÊNDICE D - SIMULAÇÃO 3

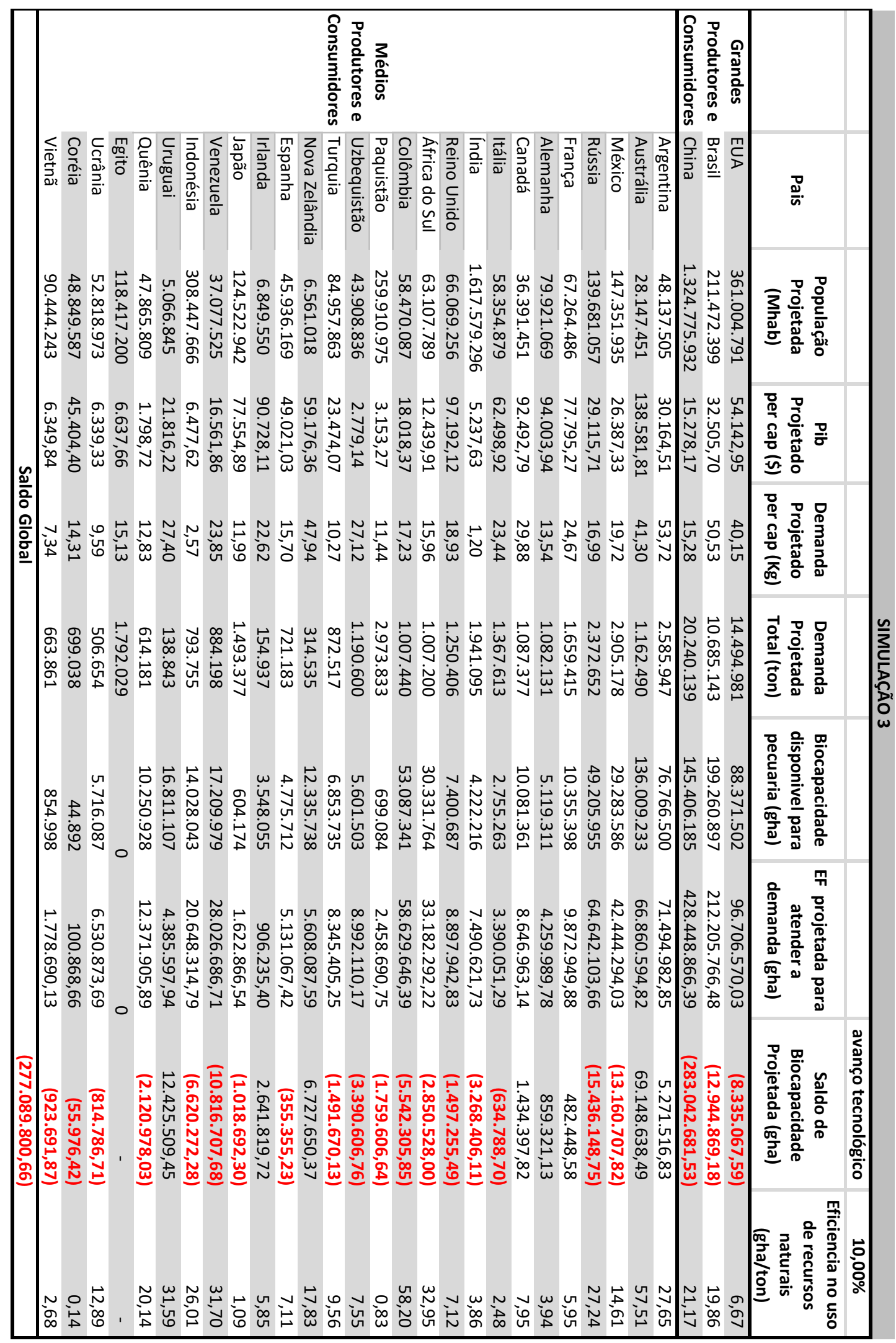




\section{APÊNDICE E - SIMULAÇ̃̃O 4}

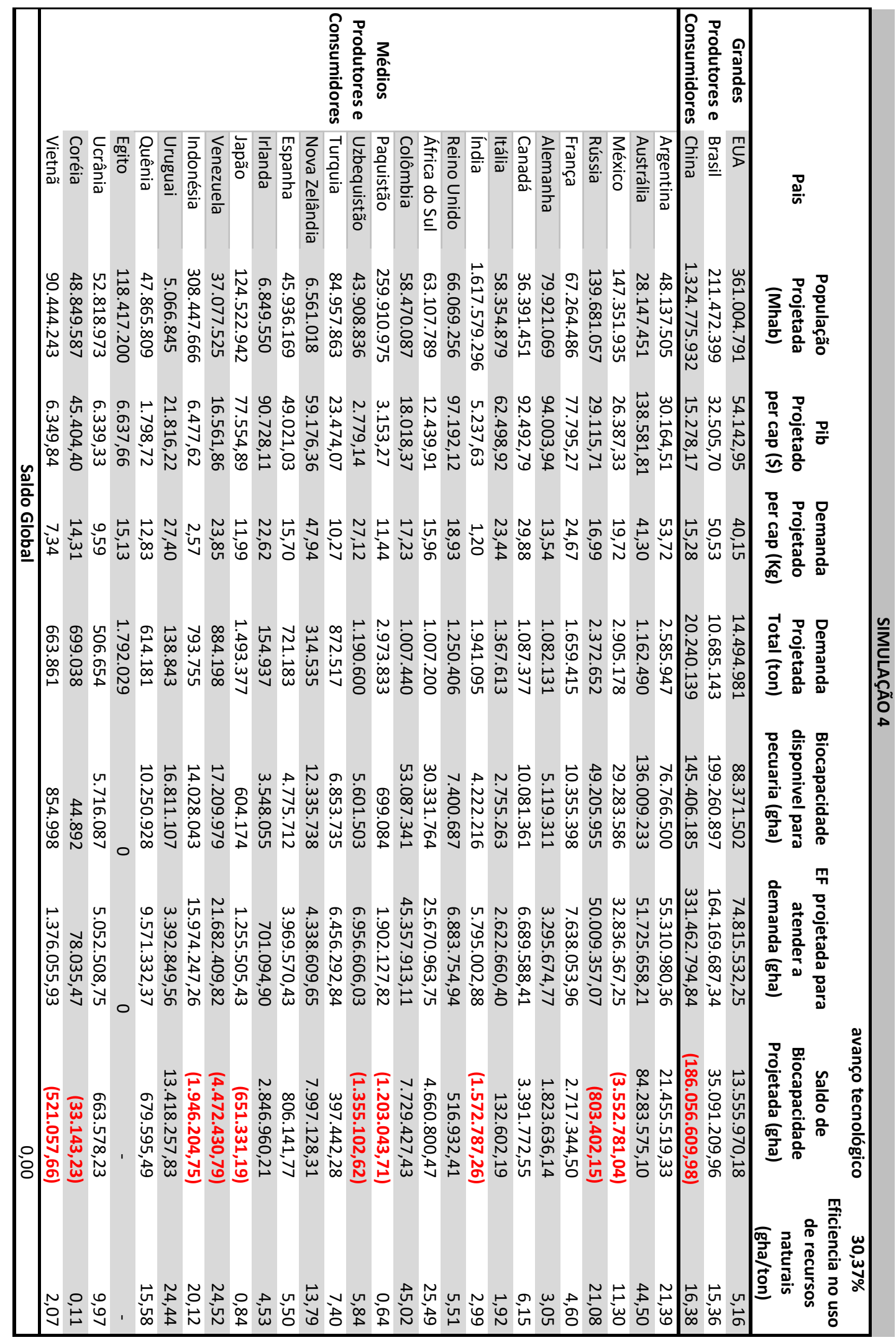

